
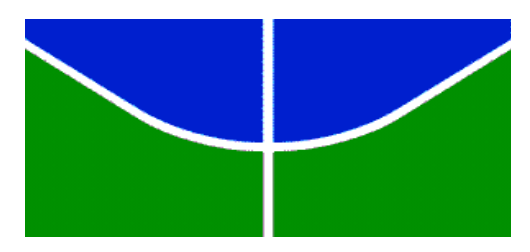

Universidade de Brasília

Centro de Estudos Avançados Multidisciplinares

Programa de Pós-Graduação em Direitos Humanos e Cidadania

\title{
A MOBILIZAÇÃO TRANSNACIONAL DO DIREITO \\ E O SISTEMA INTERAMERICANO DE DIREITOS HUMANOS: \\ O CASO ANÍBAL BRUNO
}

Julia Barros Schirmer

Brasília / DF

2016 

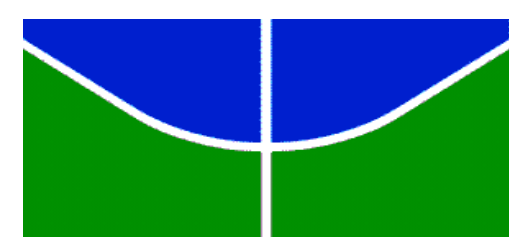

\title{
A MOBILIZAÇÃO TRANSNACIONAL DO DIREITO E O SISTEMA INTERAMERICANO DE DIREITOS HUMANOS: O CASO ANÍBAL BRUNO
}

\author{
Julia Barros Schirmer
}

Dissertação apresentada ao Programa de PósGraduação em Direitos Humanos e Cidadania, da Universidade de Brasília.

Área de Concentração: Direitos Humanos e Cidadania.

Linha de Pesquisa: Direitos Humanos, Democracia, Construção de Identidades/Diversidades e Movimentos Sociais -, como requisito parcial para obtenção do título de Mestre em Direitos Humanos.

Orientador: Prof. Dr. Wellington Lourenço de Almeida 


\section{DEDICATÓRIA}

À minha avó Joaninha, que, por meio de seu exemplo de vida e amor infinito, influencioume mais do que nós duas jamais poderíamos imaginar.

À minha mãe e aos meus pais, por sempre estarem ao meu lado e por terem me constituído no que orgulhosamente sou hoje.

Ao Vermelho, pela parceria amorosa que me inspira todos os dias em busca da justiça e dos direitos humanos.

Às defensoras e defensores de direitos humanos que trabalham todos os dias por um mundo melhor. 


\section{AGRADECIMENTOS}

Às professoras e professores do Programa de Pós-Graduação em Direitos Humanos e Cidadania da Universidade de Brasília, por sua luta pela construção do programa, que já é e ainda será espaço de tantos encontros, colaborações e projetos que, sem dúvida, daqui a alguns anos, representarão um passo importante para o desenvolvimento da teoria e da prática em direitos humanos e cidadania no Brasil.

Ao meu querido orientador, professor dr. Wellington Loureço de Almeida, gratidão pelo carinho e pela paciência. Obrigada por confiar e acreditar em mim desde o início da nossa gentil convivência.

Às professoras doutoras Rebecca Abers e Cristina Inoue, pelo olhar atento e pelas ricas contribuições na banca de qualificação e de defesa da dissertação.

Às professoras doutoras Cléria Botelho da Costa e Vanessa Maria de Castro, pelo estímulo nos debates sobre a ciência, a pesquisa e nossos projetos de dissertação.

Ao professor dr. José Geraldo de Sousa Júnior, pelo tão necessário alargamento dos horizontes jurídicos, possibilitando a minha reconciliação com o direito.

À professora dra. Ela Wiecko, pelo impulsionamento fundamental do olhar crítico na área do direito penal. Além de tudo, agradeço por ser um exemplo de professora e teórica do direito. É fundamental que as novas gerações de mulheres tenham quem admirar num espaço tão masculino quanto o do direito, ainda mais, o do direito penal.

Às professoras doutoras Rita Segato e Débora Diniz, de quem infelizmente não tive a oportunidade de ser aluna. Devo dizer, contudo, que, por meio de suas orientandas, seus posicionamentos políticos e sua escrita, contaminaram-me para sempre.

À professora Soledad García-Muñoz, coordenadora do Escritório Regional para a América do Sul do Instituto Interamericano de Direitos Humanos - IIDH, e minha madrinha na área profissional, acadêmica e amorosa: tu viste em mim o que eu ainda não tinha visto. Por conta desse olhar, hoje estou aqui. Não há palavras que expressem minha gratidão. Obrigada por sempre teres confiado em mim.

Às minhas e aos meus adoráveis colegas do Mestrado, por termos passado, juntas e juntos, por essa experiência, que é algo que guardarei dentro de mim para toda a minha vida. Nunca me senti tão acolhida em um lugar como me senti dentro dessa turma. 
Esse é o meu sim-lugar. Que continuemos sempre em contato, trabalhando em parceria pelos direitos humanos.

Às e aos colegas da Secretaria de Direitos Humanos, que sempre buscam, da melhor forma, defender os direitos humanos, em condições amplamente desfavoráveis. $\mathrm{O}$ esforço é enorme, e o trabalho, desgastante. Por isso, agradeço, e que continuem realizando esse trabalho árduo de forma tão competente. Em especial, agradeço à equipe da Assessoria Internacional, onde estive na maior parte do meu tempo na Secretaria. Às mulheres que tanto admiro, com quem trabalhei lado a lado e que me ajudaram de todas as formas possíveis nessa jornada dos anos de Brasília: Mônica Nascimento, Karolina Castro, Michelle Sá e Silva, Juliana Amoretti, Victória Balthar, Maria Beatriz Bonna, Aline Albuquerque, Luciana Peres e Juliana Benedetti. Um especial agradecimento à Maria do Rosário Nunes, por ter confiado em mim em momentos tão difíceis e delicados do nosso trabalho.

Às entrevistadas e ao entrevistado, Wilma Melo, Natália Damazio e Eduardo Baker, muito obrigada pela sua generosidade e confiança. Minha pesquisa ganhou outra energia, outro impulso a partir das vozes de vocês. Cheguei a lugares que não esperava, o que, sem sua contribuição, não teria sido possível.

À Laura Maria Loss Schwarz, amiga, irmã que fiz nessa vida, o nosso encontro é único. O nosso compromisso compartilhado pela transformação social faz com que a nossa amizade sempre se renove; aprendo contigo, das mais diversas formas, o tempo todo.

Às minhas queridas amigas e colegas de Mestrado, Larissa Araújo e Viviane Fecher, por toda a cumplicidade e por todo o sentimento. Indicação de livro, orientação para as entrevistas, revisão de capítulos, buscas em aeroporto, almoço feito em casa, impressão e entrega do trabalho, fora todo o suporte emocional: eu não teria conseguido sem vocês. Minha eterna gratidão. Contem comigo para o que for nessa vida.

À família que eu fiz em Brasília, meu querido Cleber Kemper e minhas queridas Mônica Nascimento e Maíra Carvalho, que ouviram meus lamentos, enxugaram as minhas lágrimas e me fizeram rir tantas vezes nesses anos. Muito obrigada por tudo o que vocês me deram. A experiência compartilhada nos tornou parceiros para sempre.

Ao meu querido Rodrigo de Azevedo Weimer, professor doutor, mas, melhor ainda, amigo da adolescência, que me acompanha desde então, e pôde me acompanhar também nesse trabalho. Obrigada pelas ponderações atentas e pelo estímulo.

À Eugênia Lacerda, agradeço pela orientação no árduo caminho do processo 
terapêutico. Sem tua ajuda, não conseguiria estar no lugar em que me encontro hoje, o que possibilitou, inclusive, a experiência do Mestrado e a confecção dessa dissertação.

À minha família querida, pelo apoio e pela ausência consentida que me permitiram avançar e concluir esse projeto. Apesar de não compreenderem da mesma forma que eu o significado desse trabalho e da minha militância em direitos humanos, sempre contei com seu suporte.

À Ana Maria Barros Pinto, minha mãe querida, obrigada por ter me feito assim como sou. A minha trajetória de direitos humanos está umbilicalmente ligada a ti e à tua trajetória contra a ditadura e, depois, pela democratização do país. Agradeço por tudo.

Ao meu amor, Vermelho, agradeço pelos auxílios todos, pelos debates, pela busca de livros e referências. Mais ainda, agradeço por estarmos caminhando juntos, lado a lado, nessa aventura da criação de um casamento que une amor, respeito, cumplicidade, reflexão e prática dos direitos humanos. Tudo teria sido totalmente diferente sem ti. 


\section{RESUMO}

A mobilização transnacional do direito propõe a ressignificação e a concretização dos direitos humanos a partir da formação de uma rede de organizações da sociedade civil. A normativa e os espaços institucionais internacionais de direitos humanos são, nesse contexto, mais um instrumento ao dispor da sociedade civil brasileira na construção de sua gramática e do conjunto de estratégias na luta pelos direitos humanos. O Sistema Interamericano de Direitos Humanos mostra-se, especialmente no que tange violações relativas ao sistema prisional, uma ferramenta bastante acessada pelas organizações que atuam no Brasil. Apresenta-se a perspectiva da sociedade civil no caso Aníbal Bruno como forma de investigar os impactos produzidos e o alcance conquistado por uma ação coletiva junto à Comissão e à Corte Interamericana de Direitos Humanos, desde o olhar das organizações construtoras de uma rede de atuação transnacional no sentido da promoção e da proteção das pessoas privadas de liberdade.

Palavras-chave:

direitos humanos - mobilização - transnacionalidade - organizações da sociedade civil sistema prisional - Sistema Interamericano de Direitos Humanos 


\section{RESUMEN}

La movilización transnacional del derecho propone la redefinición y la realización de los derechos humanos desde la perspectiva de la formación de una red de organizaciones de la sociedad civil. Las reglas y los espacios institucionales internacionales de derechos humanos son, en este contexto, un instrumento a más a disposición de la sociedad civil brasileña en la construcción de su gramática y de un conjunto de estrategias en la lucha por los derechos humanos. El Sistema Interamericano de Derechos Humanos se presenta, especialmente en relación con violaciónes relacionadas con el sistema penitenciario, una herramienta con mucho acceso para las organizaciones que actuan en Brasil. Muestra-se la perspectiva de la sociedad civil en el caso de Anibal Bruno como una manera de investigar los impactos producidos y el alcance logrado mediante la acción colectiva en la Comisión y la Corte Interamericana de Derechos Humanos, desde la mirada de las organizaciones constructoras de una red de actuación transnacional en sentido de la promoción y la protección de las personas privadas de la libertad.

Palabras clave:

derechos humanos - movilización - transnacionalidad - organizaciones de la sociedad civil - sistema carcelario - Sistema Interamericano de Derechos Humanos 


\begin{abstract}
Transnational mobilization of law proposes a redefinition and the realization of human rights as consequence of the composition of a network of civil society organizations. International human rights normative and international institutional spaces of human rights are, in this context, another instrument available to the Brazilian civil society towards building the gramatics and set of strategies in the on-going struggle for human rights. The InterAmerican Human Rights System is regarded, especially reffering to violations related to the prison system, as a highly accessed tool for organizations in Brazil. Exploring the perspective of civil society in the case Anibal Bruno is a way to investigate the impacts produced and the scope achieved by collective action by the Commission and the InterAmerican Court of Human Rights, from the point of view of organization's construction of a transnational network towards the promotion and protection of persons deprived of liberty.
\end{abstract}

Keywords:

human rights - mobilization - transnationality - civil society organizations - prison system - Inter-American Human Rights System 


\section{LISTA DE ABREVIATURAS}

AGU - Advocacia-Geral da União

CADH - Convenção Americana de Direitos Humanos

CF - Constituição da República Federativa do Brasil

CIDH - Comissão Interamericana de Direitos Humanos

CIDFP - Convenção Interamericana sobre Desaparecimento Forçado de Pessoas

CIDI - Convenção Interamericana contra toda forma de Discriminação e Intolerância

CIPPT - Convenção Interamericana para Prevenir e Punir a Tortura

CIRDRI - Convenção Interamericana contra o racismo, a Discriminação Racial e formas conexas de Intolerância

CNDH - Conselho Nacional de Direitos Humanos

CNJ - Conselho Nacional de Justiça

CNMP - Conselho Nacional do Ministério Público

CNPCP - Conselho Nacional de Política Criminal e Penitenciária

CNPCT - Comitê Nacional de Prevenção e Combate à Tortura

Corte IDH - Corte Interamericana de Direitos Humanos

DADDH - Declaração Americana dos Direitos e Deveres do Homem

DEPEN - Departamento Penitenciário Nacional

DMF - Departamento de Monitoramento e Fiscalização do Sistema Carcerário e Socioeducativo

DPI/AGU - Departamento Internacional

GAJOP - Gabinete de Assessoria Jurídica às Organizações Populares

HRW - Human Rights Watch

LEP - Lei de Execução Penal

MJ - Ministério da Justiça

MNDH - Movimento Nacional dos Direitos Humanos

MNPCT - Mecanismo Nacional de Prevenção e Combate à Tortura

MRE - Ministério das Relações Exteriores

OEA - Organização dos Estados Americanos

ONU - Organização das Nações Unidas

OSC - Organização da sociedade civil 
PBPPPPLA - Princípios e Boas Práticas sobre a Proteção das Pessoas Privadas de Liberdade nas Américas

RMTP - Regras Mínimas para Tratamento de Presos das Nações Unidas

SDH/PR - Secretaria de Direitos Humanos da Presidência da República

SEJUDH - Secretaria de Justiça e Direitos Humanos

SEMPRI - Serviço Ecumênico de Militância nas Prisões

SERES - Secretaria Executiva de Ressocialização

SIDH - Sistema Interamericano de Direitos Humanos 
"Não sei se a vida é curta ou longa demais para nós, mas sei que nada do que vivemos tem sentido, se não tocamos o coração das pessoas." Cora Coralina

“É dito que ninguém conhece de verdade uma nação até que se tenha estado dentro de suas prisões. Uma nação não deveria ser julgada pela maneira com que trata seus mais nobres cidadãos, mas seus mais humildes." Nelson Mandela 


\section{SUMÁRIO}

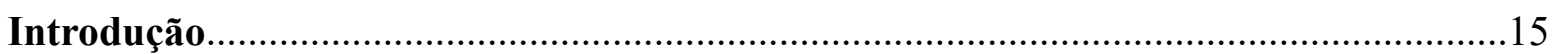

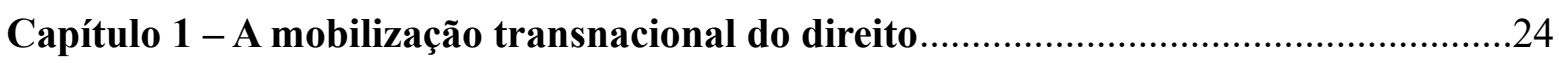

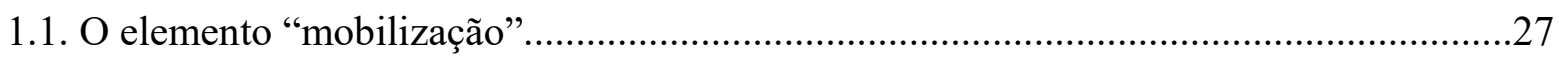

1.1.1. O protagonismo da sociedade civil....................................................................27

1.1.2. A formação de redes da/entre organizações da sociedade civil...................................33

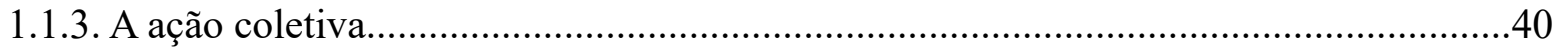

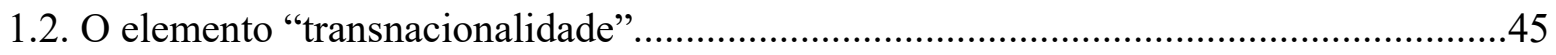

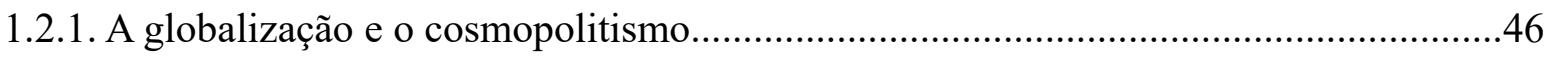

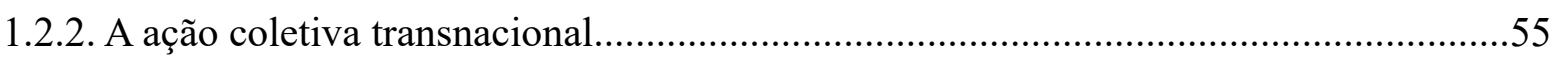

1.2.3. Órgãos supranacionais de proteção dos direitos humanos e oportunidade política......60

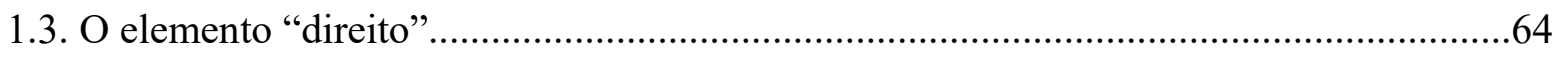

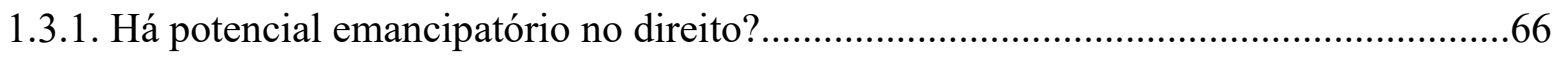

1.3.2. O acesso à justiça para além do Poder Judiciário............................................................68

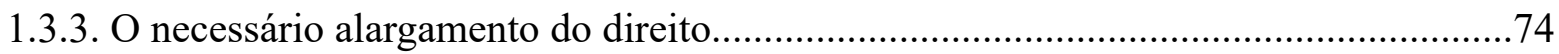

Capítulo 2 - O Presídio Professor Aníbal Bruno no SIDH..........................................79

2.1. O Sistema Interamericano de Direitos Humanos............................................................. 80

2.1.1. A normativa interamericana de proteção dos direitos humanos..................................81

2.1.2. A Comissão e a Corte Interamericana de Direitos Humanos........................................89

2.1.3. O Estado brasileiro perante o Sistema Interamericano de Direitos Humanos..............99

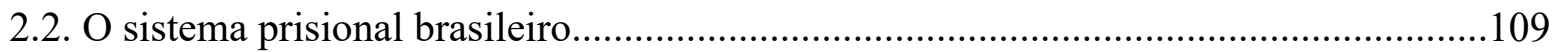

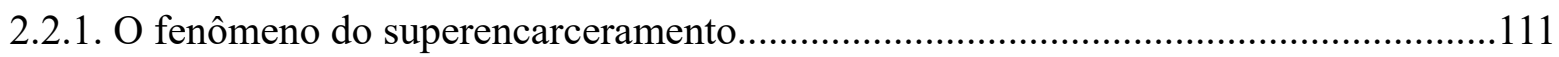

2.2.2. Registrando a realidade da miséria nas e das prisões.............................................116

2.2.3. O abismo entre a riqueza normativa e de instituições e a miséria das prisões...........122

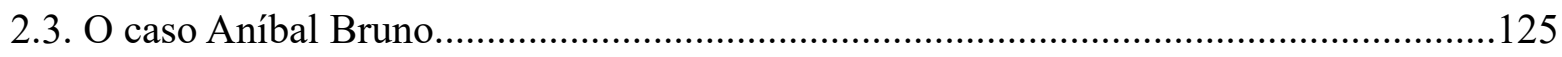

2.3.1. A mobilização do direito internacional e o ingresso da demanda..............................126

2.3.2. As medidas cautelares perante a Comissão Interamericana de Direitos Humanos....132

2.3.3. As medidas provisórias perante a Corte Interamericana de Direitos Humanos..........136

Capítulo 3 - A perspectiva das organizações da sociedade civil..................................145

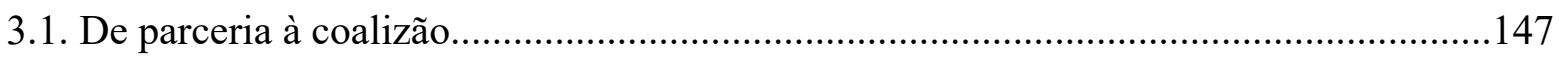

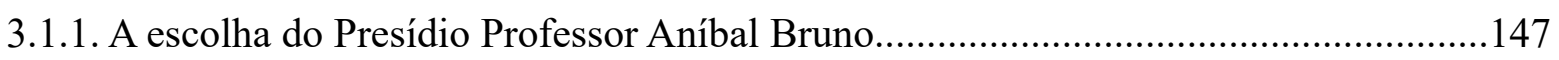

3.1.2. A escolha de um caso emblemático para debater um problema estrutural..................148 
3.1.3. O monitoramento do sistema prisional pela sociedade civil pernambucana.

3.1.4. Defensoras de direitos humanos e a militância profissional em direitos humanos....151

3.1.5. A formação da rede. 152

3.1.6. Formação da rede a partir do pressuposto da internacionalização da demanda.........153

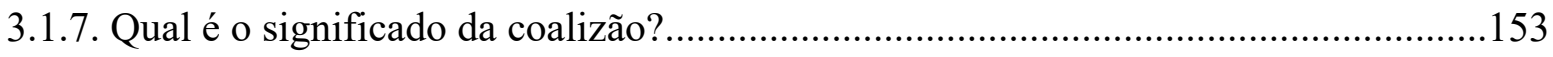

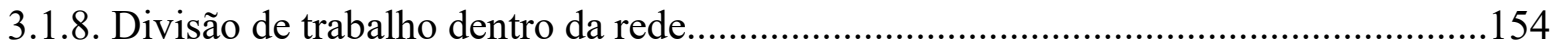

3.2. Internacionalização da demanda e obstáculos para a concretização das medidas.........156

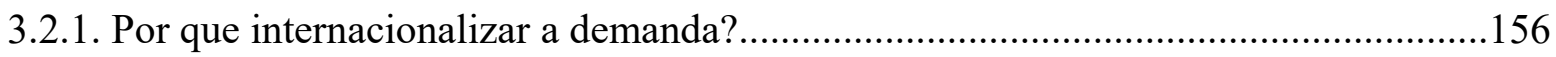

3.2.2. A tensão entre a inércia do Estado e a persistência da demanda no SIDH.................156

3.2.3. A resposta do Estado brasileiro............................................................................ 158

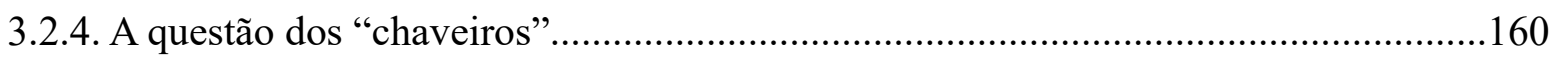

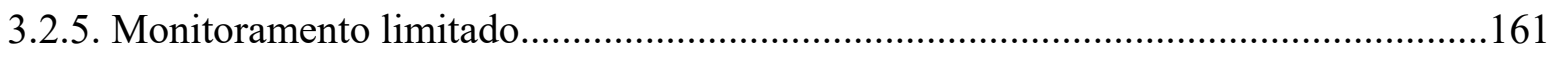

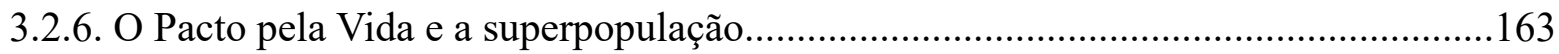

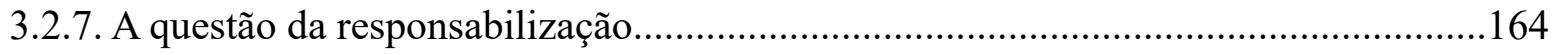

3.2.8. Presídio Professor Aníbal Bruno/Complexo do Curado.............................................165

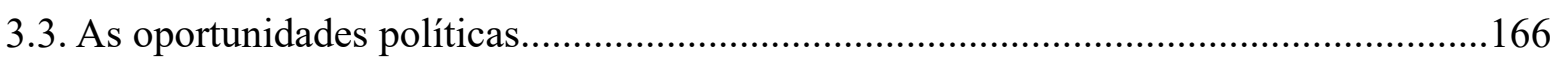

3.3.1. A preferência pelo Sistema Interamericano de Direitos Humanos..............................166

3.3.2. A existência da Corte Interamericana de Direitos Humanos......................................167

3.3.3. Diferença entre o SIDH e o Sistema das Nações Unidas...........................................167

3.3.4. O espaço mais aberto do SIDH em relação ao âmbito doméstico..............................168

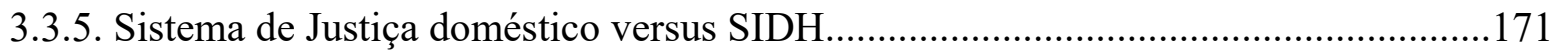

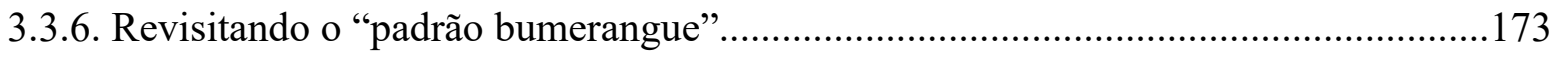

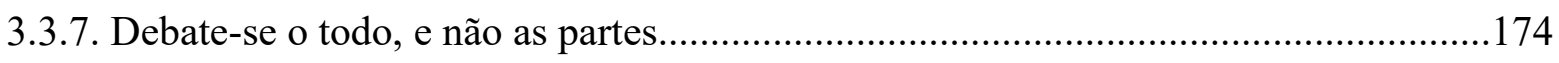

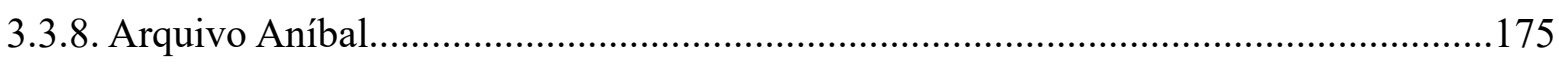

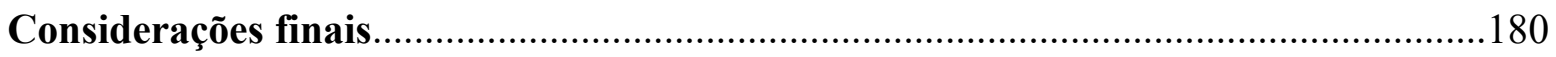

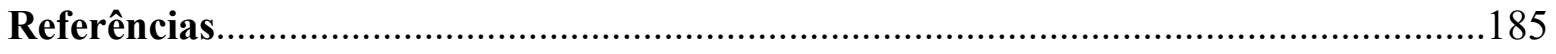

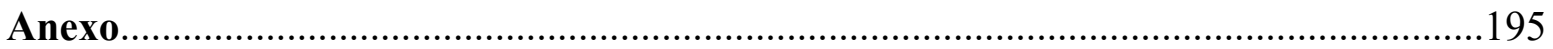




\section{INTRODUÇÃO}

A tarefa da escolha de um tema de pesquisa é complexa. Ela exige uma série de reflexões sobre as temáticas que são mais relevantes social e cientificamente, sobre aqueles que são mais fáceis de acessar, sobre aqueles que o pesquisador avalie que possa dar sua melhor contribuição. Sobretudo, o pesquisador deve ser um apaixonado pelo seu tema, até porque vai passar muito tempo envolvido com ele, o que requer, além de outros ânimos e sentimentos, paixão.

"A mobilização transnacional do direito e o Sistema Interamericano de Direitos Humanos: o caso Aníbal Bruno" pretende ser um fino equilíbrio entre o que é social e cientificamente relevante, o que se encontra acessível para a pesquisa e as paixões que impulsionam o labor acadêmico. A combinação dos temas cárcere, Sistema Interamericano de Direitos Humanos e sociedade civil é a tradução exata dessa busca.

Importante, portanto, destacar meu envolvimento com os temas.

Quanto à prisão, minhas memórias são remotas.

Em 1992, a Casa de Detenção ou o Carandiru, como a prisão paulistana era popularmente conhecida, foi palco de umas das maiores chacinas já ocorridas na história republicana do Brasil. O massacre do Carandiru, como ficou conhecido mais um capítulo da nossa violenta história, produziu 111 mortos. Presos que estavam em rebelião por conta de melhoria de condições de sobrevivência dentro do estabelecimento carcerário.

Então, eu tinha doze anos de idade. O episódio do massacre marcou-me profundamente naquele momento e para o resto da vida.

Algum tempo depois, ecoando aquele sentimento, Caetano Veloso e Gilberto Gil lançaram a música "Haiti”, que tem o seguinte trecho:

\footnotetext{
E quando ouvir o silêncio sorridente de São Paulo

Diante da chacina

111 presos indefesos, mas presos são quase todos pretos

Ou quase pretos, ou quase brancos quase pretos de tão pobres

E pobres são como podres e todos sabem como se tratam os pretos
}

Para, no final, cantarem "Pense no Haiti/Reze pelo Haiti/O Haiti é aqui/O Haiti não é aqui”. Vive-se essa ambiguidade no Brasil. O Haiti é aqui e o Haiti não é aqui. A poesia, muitas vezes, é a melhor forma de captar a realidade. Um dos espaços da sociedade 
brasileira que é o Haiti é justamente o cárcere. A partir desse momento, sempre estive muito conectada com o tema.

Ainda mais remota é minha conexão com o tema da participação social.

Meus pais foram jornalistas da imprensa alternativa durante a ditadura. Uma das minhas primeiras lembranças é de estar, junto com a minha mãe, em uma manifestação pelas Diretas Já em Porto Alegre, minha cidade natal. Sempre estive envolvida com movimentos sociais, organizações não-governamentais e cooperativas sociais, inclusive e ainda com mais intensidade, durante a Faculdade de Direito, que cursei no período 1999-2004. O envolvimento estendeu-se para depois dela.

Trabalhar com o tema da sociedade civil é uma fonte inesgotável de inquietações, até por que não tive possibilidade de estudá-lo durante a graduação. A paixão pela participação social vem da ideia e do sentimento de que a transformação social somente é possível pelas mulheres e homens que fazem parte dos movimentos e organizações da sociedade civil.

Quanto ao direito internacional dos direitos humanos, a paixão é mais recente.

Durante a graduação, fui apresentada ao tema, mas, sem ter contato com pessoas ou abordagens que fizessem sentido para mim, não despertou meu interesse. Sempre avaliei, e continuo com essa avaliação, que o direito internacional, mesmo aquele que trata dos direitos humanos, é muito elitizado, distante da vida da população brasileira em geral. E avalio, da mesma forma, que não deveria ser dessa maneira.

No momento em que verifiquei a relevância concreta do direito internacional dos direitos humanos na vida das pessoas, apaixonei-me perdidamente por ele. E creio que um grande salto de qualidade para a cidadania brasileira ainda será dado pela intensificação e aprofundamento do conhecimento e prática relativas ao uso de seus instrumentos normativos e mecanismos de proteção.

Foi como assessora internacional junto à Secretaria de Direitos Humanos da Presidência da República, no período 2011-2014, que vi essa interface entre a sociedade civil e o Sistema Interamericano de Direitos Humanos. O primeiro caso em que atuei foi justamente no das Medidas Cautelares n. 199/11 - Pessoas privadas de liberdade no Presídio Professor Aníbal Bruno.

Fui algumas vezes fazer inspeção na unidade, conduzi inúmeras reuniões com os agentes estatais do Poder Executivo, Ministério Público, Poder Judiciário e com os 
peticionários do caso. A primeira vez que fui para Washington, para a Comissão Interamericana de Direitos Humanos, foi justamente para participar de uma reunião sobre o caso, coordenada pelo Comissionado Felipe González, então relator para os casos do Brasil.

Enfim, possuo um conhecimento prático em relação ao caso, assim como em relação ao Sistema Interamericano de Direitos Humanos como um todo, por conta de todos os outros casos que acompanhei, que me permitem fluência e intimidade com a matéria, o que se mostrou útil para a confecção da dissertação.

O tema geral está desenhado. Contudo, o caminho para se chegar aos objetivos foi tortuoso. Afinal, não se pode ler, refletir e escrever sobre um universo tão amplo. A junção desses elementos, a depender da profundidade conferida à investigação, poderia resultar em uma pesquisa extremamente extensa, que poderia demorar muitos anos para ser realizada. Daí a importância dos recortes para o aprimoramento do tema e formulação dos objetivos.

Neste sentido, devo apontar a preciosa contribuição do processo de submissão do projeto à banca de qualificação, com a participação de meu orientador, Prof. Dr. Wellington de Almeida, da Profa. Dra. Cristina Inoue (Instituto de Relações Internacionais/UnB) e da Profa. Dra. Rebecca Abers (PPGDH/UnB).

As professoras indicaram que o caminho deveria ser esmiuçar o conceito de mobilização transnacional do direito, que aparecia tão central no meu projeto, mas ainda desacompanhado da explicação do porquê tinha sido eleito como tal. Ressaltaram que o foco do trabalho deveria ser a análise do como, do processo, do caminho, do porquê as organizações da sociedade civil optaram pelo Sistema Interamericano de Direitos Humanos. Ainda, referiram a importância de pensar sobre o aspecto extrajudicial do Sistema Interamericano de Direitos Humanos como parte do interesse das organizações da sociedade civil em demandá-lo, ressaltando os aspectos de percepção do sentido que esse espaço tem para a sociedade civil. De forma conjunta, nos debates em que se seguiram às intervenções individuais, chegamos à ideia de que é também interessante avaliar a permeabilidade do SIDH, já que este criou espaço para oportunidades políticas a serem aproveitadas pela sociedade civil, de maneira diferente do que ocorre no espaço institucional das Nações Unidas. Ademais, restou evidente que uma das questões mais instigantes seria pensar o porquê as organizações da sociedade civil sentem a necessidade de ir para fora, sair do âmbito doméstico, levantando a ideia de que, dessa forma, sentem que são construtoras de 
algo. Ao alargarem o sentido do direito - com o direito internacional -ressignificariam seu papel ao levar uma demanda para o SIDH.

No processo de reformulação do projeto, cheguei à seguinte pergunta-problema: para as organizações da sociedade civil que trabalham com direitos humanos, qual é o significado de se tornar peticionário junto ao Sistema Interamericano de Direitos Humanos no caso Aníbal Bruno?

Quanto aos objetivos, o geral consubstancia-se em explorar o alcance e os limites da mobilização transnacional do direito, na perspectiva das organizações da sociedade civil no caso Aníbal Bruno. Em relação aos específicos, restaram dessa maneira formulados: $i$ ) analisar como ocorreu a formação da rede da sociedade civil; ii) explorar os significados nomeados pelas organizações ao decidirem ser e se manter como peticionárias do caso perante o Sistema Interamericano de Direitos Humanos; e iii) estabelecer quais são as oportunidades políticas no âmbito do Sistema Interamericano de Direitos Humanos.

Antes de continuar a explanação sobre a dissertação, devo realizar duas anotações importantes. A primeira refere-se à escolha do caso Aníbal Bruno. Como a professora Rebecca afirmou durante a banca, poderia ter sido qualquer outra unidade carcerária, afinal, existem tantas nessa mesma situação. Por que, então, o Aníbal Bruno?

Há argumentos de ordem pessoal e de ordem objetiva que explicam a eleição. Em relação ao de ordem pessoal, como foi o primeiro caso do Sistema Interamericano que acompanhei, logo quando cheguei à Assessoria Internacional, tenho muito carinho por ele. Não pelo caso em si, mas pelas pessoas envolvidas. Wilma Melo - do SEMPRI - e Padre Vilmar - da Pastoral Carcerária de Recife - foram muito atenciosos com a equipe do governo federal que aportou em Recife em setembro de 2011. Tivemos uma conexão instantânea, apesar de estarmos, a princípio, em lados opostos - sociedade civil e Estado brasileiro.

Dessa primeira impressão, nasceu uma relação de profundo respeito, admiração e abertura, que permanece até hoje. Portanto, além de ser um caso que conheço bem, tenho acesso às informações e às narrativas dos protagonistas. Devo acrescentar que, com a equipe da Justiça Global, da Pastoral Carcerária Nacional e da Clínica de Direitos Humanos de Harvard, a relação, também, sempre foi tranquila e respeitosa. Houve a compreensão de que a equipe da SDH/PR era Estado brasileiro, porém, com maior permeabilidade que o restante dos órgãos. 
Dentre as questões objetivas, avalio o caso Aníbal Bruno como de extensão mediana: nem curto demais que não existam informações o bastante para análise, nem extenso demais, o que impossibilitaria ou dificultaria demais a compreensão de todo seu complexo de informações. O caso ficou entre 2011 a 2014 na Comissão Interamericana de Direitos Humanos - onde houve produção de documentos da rede de organizações da sociedade civil, Estado brasileiro e Comissão, além de uma reunião de trabalho. Nota-se, também, que houve outorga de medidas cautelares em 2011, sendo que essas foram ampliadas em 2012, o que é um fato inusitado no âmbito do SIDH. Em seu caminho, chegou à Corte IDH em 2014, onde já houve a decretação de duas medidas provisórias, sendo que uma delas ocorreu logo após uma audiência pública em San José - em setembro de 2015 -, perante os juízes da Corte.

Entre os casos brasileiros sobre pessoas privadas de liberdade com medidas de urgência outorgadas/decretadas, há o Urso Branco, que é um caso muito extenso, com mais de 10 anos de trâmite no SIDH, e outros dois, que são o Complexo de Pedrinhas e o Presídio Central de Porto Alegre. O Presídio Central de Porto Alegre permanece na Comissão Interamericana de Direitos Humanos, apesar de ter o mesmo tempo de medidas cautelares decretadas para o Complexo de Pedrinhas. Este, por sua vez, poderia até ter sido escolhido, pois, como o Aníbal Bruno, percorreu a $\mathrm{CIDH}$ - as medidas cautelares foram decretadas no final de 2013, chegando à Corte IDH em meados de 2014.

O caso Complexo de Pedrinhas poderia também ser interessante, apenas sendo meu conhecimento do caso diferente, já que não o acompanhei diretamente. Ou seja, não teria o acesso facilitado como no caso Aníbal Bruno. Ainda, aponta-se que as organizações envolvidas no caso Aníbal Bruno são exemplares para um trabalho como o presente, porquanto se propõe a avaliar o ponto de vista das organizações da sociedade civil. A diversidade de perfis é grande: o Serviço Ecumênico de Militância nas Prisões - SEMPRI e a Pastoral Carcerária em Pernambuco, atuando precipuamente no âmbito local; a Justiça Global e a Pastoral Carcerária Nacional, atuando precipuamente no âmbito nacional; e a Clínica de Direitos Humanos de Harvard¹ e a Justiça Global, atuando precipuamente no

1 A Clínica de Direitos Humanos da Universidade de Harvard é uma entidade acadêmica, que possibilita a prática do direito internacional dos direitos humanos para os alunos da referida universidade. A experiência nos Estados Unidos com clínicas para a prática do direito já vem de algumas décadas, sendo algo relativamente novo no Brasil. Contudo, ao me aproximar do tema no campo teórico e prático - desde maio de 2015 , faço parte de um grupo de trabalho que está desenvolvendo uma experiência de prática de direitos humanos na Faculdade de Direito da Universidade Federal do Rio Grande do Sul - tenho impressão de que a junção de acadêmicos com militantes de direitos humanos é uma ação que rende resultados interessantes. Consiste em tema relevante para ser investigado posteriormente. 
âmbito internacional.

O segundo ponto a ser esclarecido é sobre a denominação do caso. Pode ficar um pouco confuso para o leitor, mas há razões para se continuar a chamar o caso de Aníbal Bruno, mesmo que o governo de Pernambuco tenha modificado seu nome em 2013. Tal razão ficará manifesta no decorrer da leitura da dissertação. Somente se aponta que as organizações da sociedade civil continuam chamando o caso de Aníbal Bruno, o que, em razão da dissertação propor a perspectiva da sociedade civil sobre o tema, já é justificativa o suficiente para se continuar a denominá-lo dessa forma. Contudo, deve-se alertar que a Corte IDH tem denominado o caso de Complexo do Curado, que é o nome atual das três unidades. Em função disso, por vezes, ver-se-á na presente dissertação também a referência sob a forma de "Complexo do Curado" ou "Aníbal Bruno/Complexo do Curado" ou "Complexo do Curado/Aníbal Bruno", a depender de que perspectiva estão se avaliando os fatos naquele determinado momento.

Feitas essas observações, passo à breve descrição dos capítulos.

No primeiro, de cunho predominantemente teórico, esmiúça-se o conceito de mobilização transnacional do direito, a partir de outros conceitos e ideias que dão consistência àquele. Dividido em três partes, o capítulo apresenta um debate sobre o elemento "mobilização", tratando sobre o protagonismo da sociedade civil, a formação de redes da/entre organizações da sociedade civil e a ação coletiva. Depois, trabalha-se com o elemento "transnacionalidade", em que se exploram algumas ideias relativas à globalização e ao cosmopolitismo, ação coletiva transnacional e os órgãos supranacionais de proteção dos direitos humanos e a oportunidade política. Ainda, foca-se no elemento "direito", investigando-se o potencial emancipatório do direito, o acesso à justiça para além do Poder Judiciário e o necessário alargamento do direito.

No segundo capítulo, analisa-se o caso Aníbal Bruno de vários ângulos. Primeiramente, trata-se sobre o Sistema Interamericano de Direitos Humanos, sua normativa, seus meios de proteção - Comissão e Corte Interamericana de Direitos Humanos - e, finalmente, algumas questões sobre a relação do Estado brasileiro com o SIDH. Depois, atenta-se para o tema do sistema prisional brasileiro, a fim de contextualizar o caso num quadro mais amplo de violações de direitos humanos. São tratadas, portanto, as questões sobre o fenômeno do superencarceramento, a realidade da miséria nas e das prisões e o abismo entre a riqueza normativa e de instituições e a realidade de miséria das prisões. Ao 
final, trabalha-se com a ideia da mobilização do direito internacional dos direitos humanos e como se deu o ingresso da demanda, a descrição do trâmite das medidas cautelares perante a Comissão Interamericana de Direitos Humanos, assim como das medidas provisórias perante a Corte Interamericana de Direitos Humanos ${ }^{2}$.

No capítulo terceiro, apresentam-se as perspectivas das organizações da sociedade civil que demandam junto ao Sistema Interamericano de Direitos Humanos no caso. Representantes do Serviço Ecumênico de Militância nas Prisões - SEMPRI e da Justiça Global foram entrevistados com a finalidade de expor seu ponto de vista sobre como percebem o Sistema Interamericano de Direitos Humanos e o caso Aníbal Bruno. Algumas questões são levantadas quando se pergunta sobre como se formou e como funciona a rede de organizações e, ainda, como ocorreu a escolha do Presídio Professor Aníbal Bruno. Quando da pergunta sobre a divisão do trabalho dentro da rede, descobriu-se que eles se autodenominam coalizão, justamente em razão da horizontalidade que há entre os membros da rede. Num segundo plano, foram agrupadas as respostas que tinham relação com o debate sobre a internacionalização da demanda e os obstáculos impostos pelo Estado brasileiro para a concretização das medidas, tais como a questão dos "chaveiros", o monitoramento limitado, o Pacto pela Vida e a dificuldade para a responsabilização dos agentes públicos. Numa terceira parte, debatem-se as oportunidades políticas de se ter um caso no SIDH. Assim, reúnem-se as respostas envolvendo a preferência pelo Sistema relativamente às Nações Unidas, assim como se esboça uma comparação entre o SIDH e o Sistema de Justiça doméstico.

Em função do desejo de estudar e trabalhar no campo teórico com os temas SIDH, sistema prisional e sociedade civil, decidiu-se escolher um caso que pudesse ser esmiuçado, a fim de que se conhecesse ao máximo os recantos da CIDH e da Corte IDH. A descrição minuciosa de um caso é importante para que se possa desvendar o SIDH a partir de sua prática, dos seus detalhes, do seu dia a dia, e não da maneira com que normalmente se faz, por meio dos instrumentos normativos, descrição dos órgãos de proteção e alguns posicionamentos jurisprudenciais pela leitura de julgados da Corte IDH.

2 Importante referir nesse ponto que não serão analisadas as manifestações do Estado brasileiro, visto que já são muitas as manifestações a serem analisadas, apenas entre aquelas das organizações da sociedade civil, da Comissão e da Corte IDH. Além da extensão, o foco do trabalho é justamente a perspectiva das organizações da sociedade civil. Se as respostas do Estado brasileiro fossem particularmente pertinentes para a compreensão de algum ponto em relação à perspectiva da rede de organizações, haveria tal aproximação. Contudo, não é o caso. Normalmente, a resposta estatal é insuficiente, com dados que entram em confronto com aqueles coletados pelos representantes dos beneficiários e, ainda, são geralmente intenções e projetos de ações e não ações concretizadas, com resultados já consolidados a serem demonstrados. 
Nas entrevistas, foram priorizados cinco temas no contato com as organizações da sociedade civil, os quais guardam relação com os objetivos específicos: i) a formação da rede de organizações; ii) seu funcionamento; iii) a formulação da demanda internacional; iv) decisão de internacionalização da demanda; e v) preferência pelo SIDH.

Quanto à formação da rede, basicamente, investiga-se como tal evento ocorre e se a rede se formou para ingressar com a demanda no SIDH. Quanto ao funcionamento, busca-se desvendar como funciona a rede, se existe uma divisão de tarefas, que estratégias foram inicialmente pensadas e como elas foram mudando ao longo do tempo, quando algum obstáculo se colocou no caminho da rede de organizações. Também se pergunta a respeito da circulação de informação, se todos têm acesso a toda a informação ou se isso é feito de forma diferente. Em relação à formulação da demanda, questiona-se as razões pelas quais o Presídio Professor Aníbal Bruno foi escolhido entre todas as unidades de Pernambuco, que critérios foram utilizados para essa escolha. Nesse ponto, explora-se o interesse da rede em expandir a discussão, a partir do caso individual, para o sistema prisional de Pernambuco ou, mesmo, para todo o sistema prisional brasileiro. Na sequência, buscam-se informações a respeito de como se deu o processo de decisão sobre a internacionalização da demanda. Não apenas vendo o SIDH como um espaço político subsidiário - esgotados os recursos internos, leva-se o caso a diante para o plano internacional -, interessa-se pela perspectiva das organizações sobre o plano doméstico, perscrutando se existe algum espaço dentro do Estado brasileiro em que se produzam resultados similares para as organizações aos que são produzidos na Comissão e na Corte Interamericana de Direitos Humanos. Pergunta-se, ainda, sobre o esgotamento dos recursos internos, como esse obstáculo ao ingresso de demandas no SIDH é avaliado pelas organizações e por que houve a decisão de ingresso de medidas cautelares. Sobre a preferência das organizações em relação ao SIDH, procura-se compreender qual é seu atrativo para a rede organizações, em detrimento de outras possibilidades internacionais; de modo específico, por que não levaram o caso para as Nações Unidas. Ainda, questiona-se sobre se pensaram em algum outro espaço institucional - internacional ou nacional - e se a rede tem acionado, de alguma forma, outro meio de proteção das Nações Unidas nesse mesmo período de tempo.

O direito funciona a partir da descrição de uma ficção, que difere, e muito, da realidade. Tanto trabalhando com direito internacional, quanto com questões relacionadas ao sistema prisional, percebo-me envolvida com a produção de textos que destacam os aspectos 
normativos desses mundos e não propriamente com as suas realidades. Identifico nesse ponto exato uma grave dificuldade para transformar a realidade. Ao apenas descrever as normas jurídicas e suas instituições, não se poderá realizar um diagnóstico sobre a nossa realidade e, muito menos, influenciar os rumos que transformam e transformarão a sociedade. A produção acadêmica do direito, além de se basear na descrição da norma e das instituições, habitualmente centra-se na visão estadocêntrica dos fenômenos sociais. Mais uma vez, esse recorte não possibilita outras perspectivas sobre a realidade que nos cerca. A sociedade civil fica apenas como coadjuvante, a reboque das ações levadas a cabo pelo Estado.

A fim de realizar uma contraposição a esse estado de coisas, escolhi trabalhar, dentro do meu tema, na interface entre Sistema Interamericano de Direitos Humanos e sistema prisional brasileiro, com a perspectiva da sociedade civil, a fim de compreender, a partir de seu olhar, como é construída sua ação coletiva, como ocorre a mobilização do direito desde o seu ponto de vista.

Ao se aproximar da realidade das violações de direitos humanos - e não da prescrição de normas protetivas desses direitos -, assim como fazê-lo desde o olhar da sociedade civil, no sentido de explorar o processo de construção da ação coletiva, o estudo do caso Aníbal Bruno possibilita a demonstração de um grupo heterogêneo de organizações da sociedade civil que busca transformar a realidade de violação de direitos humanos de pessoas privadas de liberdade. 


\section{CAPÍTULO 1 - A MOBILIZAÇÃO TRANSNACIONAL DO DIREITO}

Esse capítulo apresenta um debate sobre alguns conceitos que trazem densidade à expressão "mobilização transnacional do direito". A expressão foi utilizada por Cecília MacDowell Santos, em livro de 2012, intitulado “A Mobilização Transnacional do Direito: Portugal e o Tribunal Europeu dos Direitos Humanos".

Meu primeiro contato, entretanto, com trabalho de MacDowell Santos, se deu com a leitura de um artigo, "Ativismo jurídico transnacional e o Estado: reflexões sobre os casos apresentados contra o Brasil na Comissão Interamericana de Direitos Humanos" (2007), no qual a autora discute os impactos produzidos por três casos de violação de direitos humanos contra o Estado brasileiro em trâmite junto à Comissão Interamericana de Direitos Humanos 3 . Para além do inusitado foco na Comissão Interamericana de Direitos Humanos, pareceu-me interessante e inovador que sua análise tenha jogado luz sobre o papel das organizações da sociedade civil no contexto do Sistema Interamericano, ao invés de somente explorar os contornos da posição estatal ${ }^{4}$.

Apesar de o artigo trazer em seu título a expressão "ativismo jurídico transnacional", a autora faz, em suas primeiras páginas, a indagação norteadora da pesquisa, que é justamente "refletir sobre a relação entre a mobilização jurídica transnacional e o Estado através de uma análise do uso crescente, por ONGs locais e transnacionais de direitos

3 Os casos tratados foram Guerrilha do Araguaia, Maria da Penha e Simone Diniz. O primeiro já trilhou seu caminho até a Corte IDH e produziu enorme impacto com a decretação da sentença (Caso Gomes Lund e outros vs. Brasil, de 24 de novembro de 2010). Os outros dois ainda se encontram ativos no âmbito da Comissão Interamericana. Em especial, o caso Maria da Penha é paradigmático de uma demanda que, apenas perante a Comissão, produziu uma série de efeitos práticos, sendo o mais conhecido de todos - e, aliás, talvez o mais conhecido e reconhecido de todos os efeitos produzidos por qualquer caso brasileiro no Sistema Interamericano de Direitos Humanos - a produção de uma legislação específica para combater a violência doméstica e familiar contra a mulher, consubstanciada na Lei Maria da Penha (Lei Federal n. 11.340 de 7 de agosto de 2006). O caso Simone Diniz refere-se, primordialmente, a uma demanda envolvendo discriminação racial.

4 Há uma tendência em relação à produção jurídico-acadêmica sobre o Sistema Interamericano de Direitos Humanos no Brasil: os recortes referem-se às sentenças da Corte Interamericana, sob o argumento de que essas possuem força vinculante e observância obrigatória pelo Estado brasileiro, assim como a forma de sua execução pelo Estado brasileiro. MacDowell Santos (2007, p. 30) afirma, de forma contundente, que "(...) os juristas têm abordado o fenômeno da judicialização global e da litigância transnacional a partir de uma perspectiva restrita, legalista. (...) Quando discutem violações de direitos humanos eles também tratam das disputas de uma perspectiva individualista, como se os interesses das partes em questão e os remédios buscados por eles dissessem respeito apenas a questões legais e pudessem ser separados da política e da cultura. Além disso, os juristas frequentemente abordam as cortes internacionais e as instituições quase judiciais ou como entidades separadas, ou como instituições fundidas em uma só 'comunidade de cortes' em desenvolvimento. Ambas as perspectivas desconsideram o papel que as ONGs e os Estados nacionais possuem como partes envolvidas nas disputas domésticas e internacionais, bem como na constituição dos sistemas judicial e quase judicial tanto interno quanto internacional". 
humanos, dos instrumentos jurídicos internacionais para o reconhecimento e proteção desses direitos" (MACDOWELL SANTOS, 2007, p. 27-28). Grifei a expressão acima para demonstrar que, mesmo não aparecendo no título do artigo ou mesmo exatamente escrita dessa forma, a mobilização transnacional do direito ${ }^{5}$, que aparece em sua obra de 2012 , já estava contida ali no objeto a ser esmiuçado ao longo do texto.

$\mathrm{O}$ enfoque me pareceu tão interessante e inovador, justamente porque percebia então, e ainda hoje percebo, que a quase totalidade ${ }^{6}$ dos exames jurídicos realizados sobre o Sistema Interamericano de Direitos Humanos dá-se em torno de duas discussões: $a$ ) sobre a relação hierárquica estabelecida entre as normas jurídicas nacionais e internacionais; e $b$ ) sobre a executabilidade das sentenças da Corte. Ambos os enfoques são sobremaneira restritivos, subestimando-se a importância e a relevância jurídica ${ }^{7}$, social e política que há nas demandas das vítimas e da sociedade civil organizada, as quais dão base aos procedimentos junto à Comissão Interamericana de Direitos Humanos.

A Comissão resta esquecida frente a imperatividade jurídica representada pela

\footnotetext{
5 Mobilização é um termo mais esclarecedor que ativismo. Ativismo é uma palavra que está muito relacionada, no âmbito do Direito, a um debate sobre a extrapolação do Poder Judiciário em relação às competências constitucionais que possuem vis-à-vis as competências repartidas com os outros poderes dentro do Estado Democrático de Direito. O chamado ativismo judicial vem sendo celebrado por uns, criticado por outros, mas, de qualquer sorte, tem marcado a expressão ativismo, dentro da nossa realidade política, social e acadêmica, identificando-a com a postura de juízes que, ao adentrarem na competência do Poder Legislativo, por exemplo, acabam por colocar em desequilíbrio o controle mútuo de poder entre os entes estatais.

6 Um estudo feito pela FGV, coordenado por Oscar Vilhena Vieira e publicado em 2013, chamado "Implementação das recomendações e decisões do sistema interamericano de direitos humanos no Brasil: institucionalização e política", a bom tempo, inverte essa lógica de prioridades de análise e coloca em pé de igualdade os dados e reflexões sobre a Comissão e a Corte Interamericana de Direitos Humanos, trazendo uma nova perspectiva sobre o tema para o Direito brasileiro. Flávia Piovesan (2014), Carlos Weis (2010) e André de Carvalho Ramos (2013) são autores do Direito que trabalham com o foco mais aberto, contemplando a estrutura, procedimentos e seus efeitos práticos também junto à Comissão Interamericana de Direitos Humanos.

7 Apenas para ficar na relevância jurídica, já que a social e a política terão espaço para debate posteriormente no trabalho, nota-se que a Comissão Interamericana é um órgão quase-judicial, que produz, sim, efeitos jurídicos indiscutíveis, ao menos no seu sistema de casos e petições. Tanto é que há discussões feitas até o exame de admissibilidade de uma petição perante a CIDH que, depois, não podem ser refeitas perante a Corte. O que quer dizer que a Comissão determina, em sua sede, os contornos de um caso, assim como se haverá seguimento ou não para ele no âmbito da Corte Interamericana. Nota-se, por exemplo, que a primeira sentença contra o Estado brasileiro, o caso Damião Ximenes Lopes versus Estado brasileiro, foi fruto de uma atuação estatal não existente em todo o procedimento no âmbito da Comissão. Quando o caso aportou à Corte, depois de 6 anos de tramitação na Comissão (1999-2004), o Estado brasileiro pretendeu rediscutir o não-esgotamento dos recursos internos em sede de exceção preliminar perante a Corte, o que foi frontalmente rechaçado pelos juízes (voto a parte nas exceções preliminares do Juiz Cançado Trindade: "Coincido plenamente con la presente Sentencia de la Corte Interamericana sobre la excepción preliminar, que refleja su jurisprudencia constante, y la tesis que vengo sustentando hace más de dos décadas, a saber que, en el ámbito del Derecho Internacional de los Derechos Humanos, la excepción preliminar de no agotamiento de recursos internos es de pura admisibilidad, a ser interpuesta por el Estado demandado in limite litis, sin lo que se presume su renuncia tácita por parte del Estado demandado"). Esse caso tornou-se um emblema de como não deve ser a atuação estatal no Sistema Interamericano de Direitos Humanos.
} 
Corte Interamericana de Direitos Humanos. O mesmo processo desenrola-se em relação às vítimas e à sociedade civil que recorrem ao Sistema: suas estratégias e seus caminhos restam invisibilizados, enquanto são exploradas apenas as sentenças da Corte, sua jurisprudência, como sua estrutura funciona e como o Estado cumpre - ou deixa de cumprir - os dispositivos de suas condenações. Os estudos centram-se, quase que na sua totalidade, em como o Estado e, ainda assim, enquanto um ente homogêneo ${ }^{8}$, responde ao Sistema, mais especificamente, à Corte Interamericana de Direitos Humanos.

Os exames ficam, portanto, restritos ao debate sobre a hierarquia das fontes do direito, ainda numa posição hegemônica da supremacia da norma nacional sobre a norma internacional'; contudo, nesse movimento, deixa-se para trás uma série de importantes questões referentes às possibilidades de atuação no âmbito da Comissão Interamericana de Direitos Humanos, assim como referentes ao olhar da sociedade civil e das vítimas sobre esse processo, relevantes indagações que merecem detida reflexão.

A mobilização transnacional do direito aponta no sentido da resposta a esses questionamentos, ao abrir espaço para a ideia de protagonismo da sociedade civil transnacional, que busca, constantemente, a reparação e a prevenção de violações, por meio da ressignificação e concretização dos direitos humanos.

Ao trabalhar com os conceitos de mobilização, transnacionalidade e mobilização do direito, como se fará nas próximas páginas da presente investigação, procura-se densificar as palavras, trazendo autores, ideias e reflexões pertinentes ao objeto da pesquisa. A fim de abarcar a complexidade ${ }^{10}$ do fenômeno sob estudo, cada elemento da expressão será tratado em um subcapítulo, com a finalidade de, assim, traçar o alcance, limites e potencialidades da mobilização transnacional do direito, dando-lhe contornos específicos da seara dos direitos humanos.

8 A homogeneidade do Estado é uma ficção. Em termos de direitos humanos, a característica estatal da heterogeneidade fica explícita: como o Estado é o violador, por excelência, de direitos humanos, mas possui compromissos internos e internacionais de não sê-lo e, ainda mais, de prevenir tais violações, as diferentes parcelas da burocracia movem-se, dentro de suas instituições, a partir de seus compromissos corporativos, seus valores, sua cultura institucional e suas agendas, de formas as mais variadas, produzindo resultados diferentes. Ao tentar reduzir essa riqueza a um Estado homogêneo, os juristas perdem a capacidade de desvendar e avaliar oportunidades e apontar obstáculos que há para a concretização dos direitos humanos. A diante, no capítulo segundo, a partir dessa perspectiva, far-se-á o apontamento sobre a atual configuração do Estado brasileiro para resposta ao SIDH.

9 Esse debate será enfrentado no capítulo segundo.

10 Compreende-se complexidade a partir das ideias de Edgar Morin (2007, p. 176) sobre o tema, como, por exemplo, quando afirma que “(...) se tentamos pensar no fato de que somos seres, ao mesmo tempo, físicos, biológicos, sociais, culturais, psíquicos e espirituais, é evidente que a complexidade é aquilo que tenta conceber a articulação, a identidade e a diferença de todos esses aspectos, enquanto o pensamento simplificante separa esses diferentes, ou unifica por uma redução mutilante". 


\subsection{O elemento "mobilizaçãa"}

Neste ponto, três aspectos são fundamentais para explicar as razões pelas quais reputa-se necessário o uso da palavra "mobilização" ${ }_{11}$ : a) a ideia de protagonismo da sociedade civil, em detrimento da perspectiva estadocêntrica de direitos humanos; $b$ ) a forma de mobilização da sociedade civil, ou seja, o debate sobre a formação de redes de/entre organizações da sociedade civil; e c) o resultado produzido pela mobilização, que pode ser resumido na ideia de ação coletiva.

\subsubsection{O protagonismo da sociedade civil}

\section{O Estado existe em função da sociedade civil, e não o contrário.}

Para se chegar à ideia de mobilização caracterizada pelo protagonismo da sociedade civil, debate-se aqui o caráter inerte e não-dinâmico do Estado. O que hoje é percebido de forma natural como um ente distante, enorme, pesado e onipresente, nada mais é do que uma invenção humana. O debate sobre o conceito de Estado, seus elementos e seus estágios de evolução, é especialmente denso e extenso ${ }^{12}$, sendo relevante para a presente pesquisa observar apenas algumas de suas características, a fim de se fazer um contraponto com a sociedade civil.

O Estado moderno caracteriza-se pelo monopólio do uso da força (BOBBIO, 2000, p. 456-57; 463; 557). Significa dizer que essa abstração, que paira sobre as nossas

11 O verbete "mobilização" no Dicionário Houaiss: “1) ato ou efeito de mobilizar(-se), 2) ato ou efeito de fazer entrar em campanha um corpo ordinariamente sedentário, 3) conjunto de iniciativas e medidas do governo e dos chefes militares quando se faz necessária a defesa de um país ou a preparação dele para determinada ação militar, como a convocação de reservistas, p. ex., 4) convocação e estimulação da população ou de determinados grupos sociais para que participem de alguma atividade cívica e/ou política, 5) modalidade de terapia física que visa conferir flexibilidade ao tronco e aos músculos." A origem da palavra, assim como a ideia que está por trás de todas essas acepções, é de movimento.

12 Para esclarecimento do conceito de Estado, ressalta-se as contribuições de Dalmo Dallari (1986, p. 43): “A denominação Estado (do latim status = estar firme), significando situação permanente de convivência e ligada à sociedade política, aparece pela primeira vez em 'O Príncipe' de Maquiavel, escrito em 1513 (...). De qualquer forma, é certo que o nome Estado, indicando uma sociedade política, só aparece no século XVI, e este é um dos argumentos para alguns autores que não admitem a existência do Estado antes do século XVII. Para eles, entretanto, sua tese não se reduz a uma questão de nome, sendo mais importante o argumento de que o nome Estado só pode ser aplicado com propriedade à sociedade política dotada de certas características bem definidas. A maioria dos autores, no entanto, admitindo que a sociedade ora denominada Estado é, na sua essência, igual à que existiu anteriormente, embora com nomes diversos, dá essa designação a todas as sociedades políticas que, com autoridade superior, fixaram as regras de convivência de seus membros." 
cabeças, e é parte muito significativa de nossas vidas, é o possuidor do monopólio da violência institucionalizada, acionável (a violência) caso exista a necessidade, amparada na lei. A lei é, primordialmente, instrumento do Estado, que pode ser utilizada para coagir pessoas e outros Estados a fazer ou deixar de fazer algo, com a finalidade da manutenção da paz social. Esses elementos, portanto, Estado, monopólio da força, coerção e lei são imbrincados, reforçando um ao outro, na busca pela paz social e sua manutenção.

Do ponto de vista jurídico, o Estado é uma ordem (SILVA, 2005, p. 97-98), com um fim específico e essencial de regulamentar as relações sociais entre os membros de uma determinada população, em determinado território ${ }^{13}$. Cumpre observar que, para os juristas, basta a compreensão do que é Estado - geralmente de acordo com essas linhas gerais - não importando que o próprio Estado seja uma criação da sociedade civil. Ao se adotar essa separação artificial entre Estado e sociedade civil, com base na negação de que um é consequência do outro, torna-se viável a afirmação - e todos os desdobramentos que advêm dela - de que o Estado é protagonista da vida social, sendo muitas vezes imperativo sobre a sociedade, mesmo quando exerce sua imperatividade embasado somente na burocracia vazia.

Portanto, sem a devida reflexão crítica, pode-se chegar a conclusões equivocadas em relação ao Estado e, consequentemente, à sociedade civil, como, por exemplo, de que ele sempre existiu para regular a vida humana ou de que é protagonista da vida política. Nenhuma dessas afirmações passa ilesa pelo crivo crítico.

Nesse sentido, Norberto Bobbio (1982), em um estudo fundamental sobre Antonio Gramsci, afirma que este autor compreende Estado enquanto um instrumento, um aparelho, não sendo um fim em si mesmo. Tampouco é representante de interesses universais; dentro dele, estão representados os interesses particulares somados. De acordo com Gramsci, o Estado "não é uma entidade superposta à sociedade subjacente, mas é condicionado por essa e, portanto, a essa subordinado" (GRAMSCI apud BOBBIO, 1982, p. 23). Ainda, na perspectiva gramsciana, o Estado é uma instituição de caráter transitório, não permanente, que se encontra destinado a desaparecer dentro do subjacente processo de transformação da sociedade.

As características fundamentais do Estado em Gramsci, segundo Bobbio (1982),

13 Ainda sobre a definição de Estado, numa perspectiva jurídica, José Afonso da Silva (2005, p. 98) propõe que "O Estado, como se nota, constitui-se de quatro elementos essenciais: um poder soberano de um povo situado num território com certas finalidades. E a constituição, como dissemos antes, é o conjunto de normas que organizam estes elementos constitutivos do Estado: povo, território, poder e fins". 
são de instrumentalidade, particularidade, subordinação e transitoriedade, isso tudo relativamente à sociedade civil. Em suma, adota-se, aqui, a referida posição, a de que o Estado é um instrumento da sociedade, para que essa direcione-o para onde quiser ir; é subordinado a ela, ou seja, não a condiciona, como somos levados a crer, especialmente num contexto social ainda marcado pelo autoritarismo, pelo patrimonialismo e pelo paternalismo (CARVALHO, 2012).

\section{A sociedade civil como protagonista da vida política.}

Propõe-se que o Estado é, portanto, o coadjuvante do processo político. Daí se compreende o parágrafo único do art. $1^{\circ}$ da Constituição da República Federativa Brasileira $^{14}$, que plasma um ideal oriundo do pensamento do presidente americano Abraham Lincoln: o poder é do povo, para o povo e pelo povo. Aqui, não se está desejando debater o que é povo, mas sim trazer à tona o questionamento sobre a preferência das análises acadêmicas, principalmente no âmbito do Direito, de aspectos ligados ao Estado e não à sociedade civil.

Voltando ao estudo de Bobbio (1982) sobre Gramsci, o autor afirma que Karl Marx e o próprio Gramsci contrapõem-se a Georg F. Hegel ao alçarem a sociedade civil, e não mais o Estado - como na formulação idealista hegeliana ${ }^{15}$ - ao "momento ativo e positivo do desenvolvimento histórico" (BOBBIO, 1982, p. 33). Dito de outro modo, aqueles autores ${ }^{16}$ retiram o foco do Estado, colocando um fim à tradição jusnaturalista que

$14 \mathrm{O}$ artigo $1^{\circ}$ da Constituição da República Federativa do Brasil dispõe o que se segue: “A República Federativa do Brasil, formada pela união indissolúvel dos Estados e Municípios e do Distrito Federal, constitui-se em Estado Democrático de Direito e tem como fundamentos: I - a soberania; II - a cidadania; III a dignidade da pessoa humana; IV - os valores sociais do trabalho e da livre iniciativa; V - o pluralismo político. Parágrafo único. Todo o poder emana do povo, que o exerce por meio de representantes eleitos ou diretamente, nos termos desta Constituição" (grifo meu). Aqui, nota-se que, ao lado da essência do poder político ('Todo o poder emana do povo') encontra-se a fórmula da democracia indireta ('que o exerce por meio de representantes eleitos') e a da democracia direta ('ou diretamente, nos termos desta Constituição'). Observase, ainda, que esse espaço para a democracia direta é extremamente restrito, submetendo-se a vontade popular, já deveras limitada, ao Estado (Poder Legislativo, Poder Executivo e Poder Judiciário) nos três instrumentos constitucionais previstos: plebiscito, referendo e iniciativa popular (MÜLLER, 2010). Segundo o Müller, “(...) essas três formas de legislação popular não são, na realidade, autônomas, uma vez que elas não pertencem à competência essencial do povo, que elas não formam nenhum contrapeso eficaz à legislação representativaparlamentar" (2010, p. 62).

15 O importante, aqui, é estabelecer que Marx e Gramsci superam a formulação idealista hegeliana de um Estado que é síntese superior da contradição na relação dialética entre família e sociedade.

16 Marx e Gramsci, segundo Bobbio (1982), possuem divergências quanto à forma de perceber a sociedade civil, numa discussão sobre se esta está no âmbito da superestrutura ou da estrutura. Aqui, não há o interesse em aprofundar o tema, contudo, deve-se anotar o conhecimento sobre a dissonância (BOBBIO, 1982, p. 32). 
havia chegado ao seu ápice teórico com Hegel, para marcadamente ressaltar o papel da sociedade civil.

Esse primeiro momento foi para afirmar a sociedade civil como protagonista da vida política, ao contrário de uma visão predominantemente estatal. Contudo, faz-se necessária a reflexão sobre os tipos de sociedade civil que existem.

Nesse sentido, Boaventura de Sousa Santos (2008, p. 123) trabalha com a ideia de que, no seio de uma "reemergência da sociedade civil", é possível a distinção entre três lógicas que subjazem nos movimentos: a) a concepção liberal clássica da sociedade civil; b) a concepção dos novos movimentos sociais; e c) a concepção ligada à da sociedade socialista. Enquanto a liberal clássica produz indivíduos atomizados, a concepção socialista baseia-se na reflexão teórica dissidente da fase final dos regimes socialistas do Leste Europeu. Os novos movimentos sociais apoiam-se na ideia de uma sociedade civil pósburguesa e antimaterialista.

Assim, afirma Lynn Hunt (2009) que

Quanto à primeira objeção, deve, antes de mais, salientar-se que a
'reemergência da sociedade civil' é, em si mesma, um fenômeno complexo,
nela sendo possível distinguir pelo três lógicas distintas. A primeira remete
para a concepção liberal clássica da sociedade civil (enquanto pluralidade
atomística de interesses económicos privados) e domina hoje o discurso
político, sobretudo conservador, nas sociedades capitalistas tanto centrais
como periféricas ou semiperiféricas. A segunda subjaz aos novos
movimentos sociais (ecológicos, antinucleares, pacifistas, feministas) e
demarcar-se mais ou menos radicalmente da concepção liberal, apelando
para a ideia de uma sociedade civil pós-burguesa e antimaterialista. (...) A
terceira foi a que dominou a reflexão teórica dissidente na fase final dos
regimes socialistas de Estado do Leste Europeu: a sociedade civil
socialista, distinta de qualquer das duas concepções anteriores (HUNT,
2009, p. 215).

Importante notar que as organizações da sociedade civil não estão de acordo com uma concepção ou outra, mas deve-se destacar que possuem características preponderantemente de uma ou outra concepção. Mais ainda, extrapolando essa classificação relativa à sociedade civil, pode-se afirmar que as diferentes ideologias que estão presentes nessas concepções podem ser encontradas nas organizações de promoção e proteção aos direitos humanos. Inegável, por exemplo, a afirmação de que a necessidade do peticionamento individual, que agora encontra-se alastrada tanto nos organismos regionais, quanto no universal de direitos humanos, tem como base uma concepção atomizada, 
descontextualizada e idealista - do ponto de vista filosófico - de indivíduo, potencial vítima de violação de direitos humanos.

Ainda sobre as possíveis classificações da sociedade civil, na contemporaneidade, pode-se trabalhar com a ideia de que há matrizes filosóficas que podem funcionar no sentido de agrupar as organizações (RAMOS, 2005, p. 75). Seriam as matrizes neotocquevilleana, neoliberal, habermasiana e gramsciana. Importante, para os fins desse trabalho, é notar que as três primeiras possuem a característica de "naturalização da realidade que se delineia no contexto atual, perpetuando-a e se resignando a ela como um dado da realidade imodificável” (ibid, p. 97). Nesse sentido, o autor, explicando sua opção pela matriz gramsciana, afirma que nas

\begin{abstract}
matrizes neotocquevilleana, neoliberal e habermasiana há uma naturalização da realidade que se delineia no contexto atual, perpetuando-a e se resignando a ela como um dado da realidade imodificável. Não se imagina, assim, a possibilidade real da superação do capitalismo, aceitando-se, portanto, o sistema do capital e procurando apenas melhorálo. Não se luta, assim, pela transformação do poder estatal e/ou do mercado, uma vez que estes são tidos como inatingíveis; tentado a chamálo de 'setor invisível'. O terceiro setor é o setor privado sem fins lucrativos o que se busca é o poder que está ao alcance do subalterno, do cidadão comum, o 'micropoder' foucaultiano, criado nas associações e organizações comunitárias. Portanto, luta-se dentro da - e reforçando a - ordem capitalista. Isso aponta para a necessidade de uma perspectiva distinta que busque não apenas entender a realidade, mas também transformá-la; daí a superioridade não apenas explicativa mas também política da leitura gramsciana da sociedade civil" (RAMOS, 2005, p. 97-98).
\end{abstract}

Considera-se, aqui, que a matriz gramsciana parece ser a mais compatível com as características que o universo dos direitos humanos representa. E isso nos leva a outro debate imprescindível: uma reflexão sobre a natureza dos direitos humanos merece reflexão. Sobre esse aspecto, Hunt (2009) ao traçar seu "paradoxo da auto evidência dos direitos humanos" faz o seguinte questionamento: "se a igualdade dos direitos é tão auto evidente, porque só era feita em tempos e lugares específicos?” (HUNT, 2009, p. 17-18). E, logo após, nesse mesmo sentido, faz uma colocação fundamental: não é evidente uma afirmação que demanda ser esclarecida. Mais adiante a autora revela que não há direitos humanos em estado de natureza; o que há são direitos humanos dentro de contextos, políticos, sociais, históricos (HUNT, 2009, p. 19) ${ }^{17}$.

17 Hunt (2009) afirma que "os direitos humanos só se tornam significativos quando ganham conteúdo político. Não são os direitos de humanos num estado de natureza: são os direitos de humanos em sociedade. Não são 
Seguindo essa linha de raciocínio, Hunt chega a afirmar que os direitos humanos não são auto evidentes para, ao final de seu livro, chegar à conclusão de que, em verdade, são paradoxais e auto evidentes. Nesse sentido, ao finalizar seu livro, a autora expõe a seguinte ideia:

As declarações - em 1776, 1789 e 1948 - providenciaram uma pedra de toque para esses direitos da humanidade, recorrendo ao senso do que 'não é mais aceitável' e ajudando, por sua vez, a tornar as violações ainda mais inadmissíveis. O processo tinha e tem em si uma inegável circularidade: conhecemos o significado dos direitos humanos porque nos afligimos quando são violados. As verdades dos direitos humanos talvez sejam paradoxais nesse sentido, mas, apesar disso, ainda são auto evidentes (HUNT, 2009, p. 19).

De qualquer sorte, para o presente ponto, necessário destacar que, ao se concordar com as colocações de Hunt, chega-se à conclusão de que os direitos humanos são espaços onde tensões se multiplicam, construindo novas realidades a partir de novas lutas. Tomando tal raciocínio como ponto de partida, como poder-se-ia aceitar uma matriz filosófica que não trabalhasse com a mobilização social não apenas como uma possibilidade, mas, sim, necessidade?

Com efeito, é importante assentar a escolha pela matriz gramsciana - que depois terá desdobramentos no debate sobre hegemonia, tão importante para os direitos humanos a fim de que fique clara a compreensão de que a mobilização da sociedade civil, a radicalização da democracia e a luta pelos direitos humanos são discursos e práticas imbrincadas e inafastáveis.

O conceito de mobilização auxilia na sedimentação da transição do protagonismo do Estado para a sociedade civil, já que o conceito de Estado está intimamente ligado à ideia de manutenção do status quo, enquanto o de sociedade civil, à de transformação social (SÁNCHEZ RUBIO, 2011). Estabelece-se, portanto, que o caminho para a transformação social e para a construção dos direitos humanos se dá não por meio do Estado - no sentido de que ele não se presta a ser o agente da mudança ${ }^{18}$-, mas, sim, pela sociedade civil.

apenas direitos humanos em oposição aos direitos divinos, ou direitos humanos em oposição aos direitos animais: são os direitos de humanos vis-à-vis uns aos outros. São, portanto, direitos garantidos no mundo político secular (mesmo que sejam chamados 'sagrados'), e são direitos que requerem uma participação ativa daqueles que os detêm" (HUNT, 2009, p. 19).

18 A sociedade civil deve ocupar os espaços do Estado e, por meio dele, transformar a sociedade. Mais adiante no trabalho, ainda nesse capítulo, retorna-se a esse ponto ao se refletir sobre oportunidades políticas. 


\subsubsection{A formação de redes da/entre organizações da sociedade civil}

\section{O que é uma rede?}

Fala-se muito, atualmente, em formação de $\operatorname{redes}^{19}$, nos mais diferentes níveis de atuação, tanto no âmbito estatal, quanto na iniciativa privada com fins lucrativos, assim como na sociedade civil. Em relação à literatura de redes aplicada às organizações da sociedade civil que trabalham com direitos humanos, um trabalho fundamental é o livro “Activists beyond borders", de 1998, de Margareth Keck e Kathryn Sikkink.

No prefácio, antes de adentrarem em conceituações, as autoras trazem um trecho do livro "Cem anos de solidão" de Gabriel García Márquez, em que são antecipados, de certa forma, eventos reais ocorridos na América Latina na segunda metade do século passado - no México em 1968 e na Argentina em 1976 - sendo que o primeiro evento ocorreu pouco depois do livro ter sido publicado, conferindo-lhe um caráter premonitório.

O que chama atenção das autoras, ao narrarem tais episódios, é a diferença entre um e outro cenário, o mexicano e o argentino, apartados por menos de uma década de diferença histórica. Entendem que parte importante da resposta encontra-se na existência ou não - do trabalho de uma rede doméstica e internacional de ativistas de direitos humanos ${ }^{20}$.

Analisando o caso argentino, mostrou-se evidente o trabalho de uma rede de organizações domésticas e internacionais que expressaram preocupação publicamente, em ambos os planos, e pressionaram no sentido da investigação sobre violações de direitos humanos e da responsabilização dos agentes estatais envolvidos, o que resultou em enormes impactos, principalmente quando comparada à situação do caso mexicano.

Quanto a este caso, Keck e Sikkink, afirmam que a referida violação de direitos humanos não atraiu a mesma atenção internacional. Sobre o massacre na Praça Tlatelolco, México, em 1968, e seus desdobramentos (porquê houve pouca repercussão internacional e,

$19 \mathrm{O}$ conceito de rede é amplamente debatido, tendo como uma referência, principalmente, teorias ligadas à comunicação. Contudo, para o presente trabalho, é suficiente o conceito de rede aplicado às organizações da sociedade civil, trazido por Keck e Sikkink, apresentado mais adiante no texto.

20 Keck e Sikkink (1998, Prefácio, p. viii) sobre o caso argentino: "Why was the ending so different in real life? [referência à passagem de "Cem anos de solidão"]. A key part of the explantion is the work of a network of domestic and international human rights activists who provided crucial information on events in Argentina and lobbied governments and international organizations to express concern, investigate, and bring pressure for change" (grifo meu). 
como consequência, demorada e insuficiente resposta estatal), as autoras argumentam que, naquele momento histórico, no México, não havia a consciência e a prática que fornecesse credibilidade a uma fonte independente de informação e pressão, o que deixou o governo do país com controle quase absoluto sobre o evento e suas repercussões ${ }^{21}$.

Um elemento que se sobressai, portanto, nesse início de análise, é o da comunicação $0^{22}$. A informação produzida pelas organizações, divulgadas e divididas entre elas, assim como seu uso enquanto objeto de cobrança dos governos, evidencia as possibilidades da sociedade civil quando toma a frente do processo de produção e uso da informação.

Aqui, fica claro que, no cenário mexicano, o governo possuía o controle da informação, sem a confrontação de outras produzidas por uma rede independente ligada a direitos humanos. Daí o porquê, segundo as autoras, de não ter havido repercussão internacional. Não havia a rede montada para fazer circular a informação e demandar uma resposta estatal diferente daquela que estava sendo dada.

Com base nesses dois exemplos, as autoras começam a trabalhar hipóteses que levaram a uma situação ou a outra. Uma das razões seria que a rede internacional de direitos humanos e a consciência sobre direitos humanos e as práticas criadas a partir desta não existiam ainda em 1968, ano do massacre mexicano. Já existia, contudo, à época dos desaparecimentos na Argentina. Fica demonstrado, portanto, a importância da rede ${ }^{23}$, que determinou a diferença dos cenários posteriormente às violações.

Assim, o argumento principal é de que essas redes transnacionais de organizações da sociedade civil, que trabalham com direitos humanos, potencializam as vozes daqueles que debatem, persuadem, elaboram estratégias, registram, fazem lobby, pressionam e denunciam as violações, onde quer que estejam.

As autoras esclarecem que os cientistas políticos ignoraram os atores políticos das organizações não-governamentais por não serem poderosos em termos clássicos. O

21 Keck e Sikkink (1998, Prefácio, p. ix) sobre o caso mexicano: “One key part of the answer is that the international human rights network, and the human rights consciousness and practices that it created, did not exist in 1968. Because there was no credible independent source, the Mexican government was able to control information about the event, and its low casualty figures were almost universally accepted" (grifo meu).

22 De forma bastante clara, Keck e Sikkink (1998, Prefácio, p. x) apontam que "Where the powerful impose forgetfulness, networks can provide alternative channels of communication".

23 E seguem Keck e Sikkink (1998, Prefácio, p. ix): "We argue in this book that the emergence of transnational advocacy networks helped instigate and sustain the change between 1968 and 1993. International activism around human rights finds historical echoes in past campaigns like those for the abolition of slavery and for woman suffrage, and foreshadows transnational campaigns in a multiplicity of other areas". 
mesmo ocorre no âmbito jurídico, em que a estrutura estatal é protagonista, sendo que se discute apenas a importância da área não-estatal quando esta representa interesses econômicos substanciais. No dia a dia de um caso perante o Sistema Interamericano de Direitos Humanos, como explicitar-se-á mais adiante, fica claro que a falta de poder das organizações da sociedade civil é um discurso falacioso.

A proposta das autoras serviu como fonte de inspiração para a presente dissertação. Sua busca por um mergulho nas experiências de algumas redes transnacionais, com a pretensão de trabalhar suas "origens, estratégias, limites e efetividade" ${ }^{24}$, ajudou a moldar os contornos da pesquisa.

Nesse texto de valor inestimável para os estudos das organizações da sociedade civil, as autoras conceituam redes como formas de organização que se caracterizam pela voluntariedade, reciprocidade, troca e horizontalidade de comunicação, assim como argumentam que a emergência das redes não é novidade; a novidade reside na forma com que se apresentaram nas últimas décadas:

As redes de advocacy não são novas. Podemos achar exemplos tão longe quanto o da campanha pela abolição da escravatura no século XIX. Contudo, seu número, tamanho e profissionalismo, e a velocidade, densidade e complexidade das conexões internacionais entre elas aumentou drasticamente nas últimas três décadas. (tradução livre) (1998, p. 10)

\section{O "padrão bumerangue".}

De maneira inovadora, Keck e Sikkink (1998) problematizam a formação da rede de organizações em torno da ideia do uso das estruturas de oportunidades locais e globais e as estratégias implementadas pelos atores. O debate sobre a formação de vínculos entre atores diferentes para o enfrentamento de canais políticos fechados, na expectativa de atingimento de seus objetivos por meio de contato direto com aliados internacionais. As autoras explicam o "padrão bumerangue" da seguinte forma:

Quando canais entre o Estado e seus atores domésticos estão bloqueados, a influência característica do padrão bumerangue das redes transnacionais pode ocorrer: organizações não-governamentais passam por cima de seu

24 Sobre isso, Keck e Sikkink (1998, Prefácio, p. x) continuam no seguinte sentido: "By delving into the experience of particular transnational networks, we hope to generate a more powerful understanding of their origins, strategies, limits, and effectiveness, making it possible to situate them within the rapidly changing configuration of world politics". 
Estado e buscam aliados internacionais para tentar trazer pressão a seus Estados vinda de fora. Isso é mais evidente no caso de campanhas pelos direitos humanos. De maneira semelhante, campanhas pelos direitos indígenas e campanhas ambientais que apoiam demandas de populações locais pela participação social - em projetos de desenvolvimento cujo resultado os afetariam - frequentemente envolvem esse tipo de triangulação. Conexões são importantes para ambos os lados: para os menos poderosos atores do terceiro mundo, as redes proporcionam acesso, influência e informação (e muitas vezes dinheiro) que eles não esperariam ter por eles mesmos; para os grupos do norte, eles tornam verossímil a afirmação de que estão lutando com e não apenas para os parceiros do sul. Não é surpreendente que essas relações possam produzir tensões consideráveis. Em outros temas em que os governos são inacessíveis ou surdos aos grupos cujas demandas talvez não ressoem em outros lugares, os contatos internacionais podem amplificar as demandas de grupos domésticos, alavancar espaços para novas questões e então ecoar de volta essas demandas para dentro da arena doméstica. (tradução livre) (1998, p. 12-13)

Conforme exposto no referido livro, inclusive por meio de uma figura, o "padrão bumerangue" é descrito da seguinte maneira: a) a organização A encontra bloqueio (dificuldade para pressionar/tirar da inércia) em relação ao Estado X; b) em razão disso, repassa informações para a organização B sobre a situação de violação de direitos humanos para que esta, por sua vez, pressione/tire da inércia o Estado Y; c) o Estado Y, por meio de atuação em organização intergovernamental, faz pressão junto ao Estado X, fazendo com que a denúncia de violação de direitos humanos finalmente chegue ao seu destinatário original, agora, com a força de ter se tornado uma denúncia internacional. Esse é o esquema básico do modelo, conforme se encontra no livro das autoras.

David Bassano afirma que o "padrão bumerangue" tornou-se uma das mais referidas teorias nos estudos de direitos humanos (BASSANO, 2014, p. 23-24.). Contudo, após problematizar seu funcionamento utilizando um caso prático, o autor avalia que, apesar das críticas ao modelo, seu mérito está em problematizar as situações em que as organizações da sociedade civil possam se encontrar, e não, como se poderia idealmente esperar, em acomodar, de maneira perfeita, todos os tipos de campanhas de direitos humanos que se poderiam desejar levar a cabo ${ }^{25}$.

25 Assim, Bassano argumenta no sentido de que "Perfectly charted, a fine-grain reading of an international human rights campaign would resemble an explosion of exchanges and influences as the actors try to leverage every opportunity available - in short, arrows all over. Creating a model to fit every international human rights campaign would be impossible. The point of the model is to challenge researchers in their understandings of particular movements, goading them into deeper investigation of the exchanges and problems inherent in transnational activism. It may also present researchers with a way to account for phenomenon they encounter in their studies of particular movements. Accuracy in modeling is not as important as general utility or, better still, in provoking questions" (grifo meu). 
O "padrão bumerangue" apresenta-se como uma teoria interessante ao se refletir sobre as demandas internacionais de direitos humanos, até porque, com a complexificação dos espaços intergovernamentais - conceito que será discutido em seguida - o modelo acaba por apresentar cada vez mais possibilidades. Concordando com o que propugna Bassano, o valor da proposição teórica é problematizar as mais variadas situações que existem na prática das organizações, ofertando-se um instrumento para tomada de decisão e avaliação constante das estratégias a serem implementadas.

Outra questão interessante apontada por Keck e Sikkink (1998, p. 25) é a avaliação da influência da rede de organizações de acordo com o espectro de influência resultante da ação colocada em prática ${ }^{26}$. Isto é, há os mais variados espaços e maneiras como as organizações podem exercer essa influência. Essa questão apontada pelas autoras é relevante porque coloca à disposição elementos para uma reflexão sobre as potencialidades das ações coletivas da sociedade civil, além de fomentar a criatividade e a diversidade de suas práticas.

Assim, a influência pode se dar tanto por meio da criação/levantamento de questões envolvendo direitos humanos, sobre o posicionamento do Estado, quanto por meio da formulação de agendas específicas. Como exemplo formulação de política pública de direitos humanos, pode-se afirmar que, no Brasil, a política de proteção a vítimas e testemunhas ameaçadas de morte ${ }^{27}$, que tem origem em iniciativa datada dos anos noventa, sobreveio de uma experiência da sociedade civil, que passou a fornecer segurança e proteção a pessoas por meio da atuação de uma entidade de Recife, Pernambuco ${ }^{28}$. Outra experiência

26 Acerca disso, Keck e Sikkink (1998, p. 25) ponderam da seguinte forma: "To assess the influence of advocacy networks we must look at goal achievement at several different levels. We identify the following types or stages of network influence: (1) issue creation and agenda setting; (2) influence on discursive positions of states and international organizations; (3) influence on policy change in 'target actors' which may be states, international organizations like the World Bank, or private actors like the Nestlé Corporation; and (5) influence on state behavior".

27 A referida política encontra base legal na Lei Federal n. 9.807 de 13 de julho de 1999, que estabelece normas para a organização e a manutenção de programas especiais de proteção a vítimas e a testemunhas ameaçadas, institui o Programa Federal de Assistência a Vítimas e a Testemunhas Ameaçadas e dispõe sobre a proteção de acusados ou condenados que tenham voluntariamente prestado efetiva colaboração à investigação policial e ao processo criminal.

28 Danielle Galdino (2013, p. 41) aponta que a origem do referido programa, agora uma política pública, encontra-se no seio da organização GAJOP - Gabinete de Assessoria Jurídica às Organizações Populares, que ainda se encontra operante com sede em Recife, Pernambuco: "Nesse contexto, em 1995 desenvolvia-se embrionariamente em Pernambuco uma experiência efetiva de proteção a pessoas ameaçadas, o que foi aparentemente viável às atuais tendências das políticas públicas. Ainda influenciado pelo panorama da década anterior de mobilização social pró-redemocratização, o GAJOP, com o fim de contribuir com a redução dos altos índices de impunidade no Estado, começa a desenvolver práticas informais de proteção, escondendo pessoas que denunciavam 'homicídios cometidos (ou tentados) por grupos de extermínio, agentes do crime organizado e de violência policial' (GAJOP, 1996b, p. 2)". 
a partir da qual se pode traçar o desenho dessa influência foi o Programa de Promotoras Legais Populares, que iniciou em uma organização de Porto Alegre, Rio Grande do Sul, chamada Themis Assessoria Jurídica e Estudos de Gênero ${ }^{29}$, lançando-se como modelo para outras organizações que trabalham com a questão de gênero. O programa, que desenvolve ações de educação para lideranças comunitárias femininas, depois de ter se consolidado como uma ação da sociedade civil organizada, hoje é fomentado pela Secretaria de Políticas para as Mulheres da Presidência da República ${ }^{30}$.

Quanto à influência nas posições discursivas dos Estados, tem-se um exemplo bastante recente, que extrapola a esfera do Poder Executivo - este costuma ser mais permeável à influência dos movimentos sociais e das organizações da sociedade civil ${ }^{31}$ - que é o caso do Poder Judiciário e a implantação da audiência de custódia ${ }^{32}$ no país. A organização que está levando na prática essa implementação é o Instituto de Defesa do Direito de Defesa - IDDD, com o qual o Conselho Nacional de Justiça possui acordo de cooperação técnica para que a organização empreste sua expertise para a implementação do projeto.

A terceira possibilidade de influência apontada pelas autoras ocorre em função da identificação dos atores-chave (agentes estatais, representantes de organizações internacionais, representantes de organizações privadas) e seu convencimento para a promoção de mudança de políticas. As ações de educação em direitos humanos que se busca realizar possuem, em parte, esse condão, principalmente quando são direcionadas para

29 Acerca disso, Lívia Fonseca (2012, p. 23) aponta que o modelo veio de experiências latino-americanas, tendo a seguinte origem dentro do Brasil: "Em 1993, a ONG Themis Assessoria Jurídica e Estudos de Gênero surge em Porto Alegre/RS da iniciativa de jovens de carreira jurídica como um espaço para desenvolvimento da primeira experiência de Promotoras Legais Populares do Brasil, com a ajuda do Grupo de Estudos sobre Educação, Metodologia da Pesquisa e Ação (GEEMPA) e o apoio inicial do Fundo de Apoio das Nações Unidas para o Desenvolvimento da Mulher (UNIFEM) e da Fundação Ford."

30 Para maiores informações, ver o sítio da Secretaria de Políticas para Mulheres (SPM), disponível em $<$ http://www.spm.gov.br/lei-maria-da-penha/lei-maria-da-penha/9-2-promotoras-legais-populares $>$, acesso em setembro de 2015.

$31 \mathrm{O}$ Poder Executivo tem sido mais permeável aos discursos e às práticas dos movimentos sociais e organizações da sociedade civil por uma série de fatores; contudo, não há espaço na presente investigação para a exploração dos mesmos. Entretanto, reputa-se importante o debate sobre a heterogeneidade do Estado e sua permeabilidade pelos movimentos contra-hegemônicos.

$32 \mathrm{O}$ tema da audiência de custódia tem relação direta com os temas direito internacional dos direitos humanos, Sistema Interamericano de Direitos Humanos e sistema prisional brasileiro. Por enquanto, basta destacar que o chefe do Poder Judiciário, Ministro Lewandowski, por meio de expediente administrativo, resolveu implementar a audiência de custódia - por meio de convênios com os 27 Tribunais de Justiça dos estados - que nada mais é que a apresentação da pessoa presa pela polícia a um juiz, num prazo de 24 horas de sua captura à realização da audiência. Adiante, aprofundar-se-á o assunto, já que é exemplo cristalino - e tendência - da mudança de postura do Poder Judiciário brasileiro em relação à efetividade dos tratados internacionais de direitos humanos e sua incidência na realidade do ordenamento jurídico nacional. 
agentes estatais. Exemplo desse tipo de influência foi a realização da oficina da Universidade Popular dos Movimentos Sociais - UPMS - denominada "Os direitos humanos em movimento: as organizações, as instituições e a rua", proposta pelo Conselho Nacional do Ministério Público - CNMP - e pelo Centro de Estudos Sociais da Universidade de Coimbra - CES/UC ${ }^{33}$. A oficina foi realizada em novembro de 2013, e foi um espaço de encontro entre ativistas, artistas e intelectuais engajados na luta pelos direitos humanos. Na sequência da oficina, foi realizada sessão pública para discutir e divulgar seus resultados, com a presença de representantes dos movimentos sociais, do Ministério Público e dos Poderes Executivo, Legislativo e Judiciário. De enorme engenhosidade, a atividade serviu como forma de mobilizar militantes de direitos humanos, sensibilizar agentes estatais brasileiros para temas que julgam relevantes, estreitar os laços entre a sociedade civil e Ministério Público, e, ainda, como um fórum para exposição e oitiva de denúncias de violações de direitos humanos.

Outra possibilidade, ainda, de influência é aquela que modifica o comportamento estatal. Pode-se afirmar que a forma com que o Estado brasileiro responde atualmente ao Sistema Interamericano de Direitos Humanos está diretamente ligada à pressão e a batalha de organizações na sociedade civil que trabalham com esses temas ${ }^{34}$. Nos últimos anos, parte do Estado brasileiro, mais especificamente do Poder Executivo da União, tem se mostrado extremamente permeável ao discurso da sociedade civil.

Ao se depararem com uma violação de direitos humanos, o procedimento clássico das organizações da sociedade civil - que continua, em larga medida, a ser adotado - é caracterizado por, basicamente, três ações: 1) documentar as violações de forma convincente; 2) trabalhar para prevenir outras violações do mesmo tipo; e 3) responsabilizar quem deu causa às violações (SONNENBERG \& CAVALLARO, 2012, p. 261). As formas de exercer esse mandato - o da luta pelos direitos humanos - têm sido, contudo, muito variadas.

33 Sobre a Universidade Popular dos Movimentos Sociais - UPMS, Júlia Benzaquen (2012, p. 91) afirma que é "um espaço de formação intercultural e interpolítica que promove um processo de interconhecimento e autoeducação, com o duplo objetivo de aumentar o conhecimento recíproco entre os movimentos e organizações e tornar possíveis coligações entre eles e ações coletivas conjuntas. Constitui um espaço aberto para o aprofundamento da reflexão, do debate democrático de ideias, da formulação de propostas, da troca livre de experiências e da articulação para ações eficazes, de entidades e movimentos sociais locais, nacionais e globais que se opõem ao neoliberalismo e ao domínio do mundo pelo capital e por qualquer forma de imperialismo". Para maiores detalhes sobre a atividade que ocorreu em Brasília, ver sítio disponível em $<$ http://alice.ces.uc.pt/news/?p=2776 $>$, acesso em setembro de 2015 .

34 Esse tema será aprofundado no capítulo segundo. 
Esse espectro de influência pode facilitar a avaliação das organizações da sociedade civil quanto às tarefas que devem desempenhar e atividades que podem exercer. advocacy, naming and shaming, litigância estratégica, lobby, confecção de relatórios, produção de dados e indicadores de direitos humanos, formulação de abaixo-assinados e petições, ações de comunicação e mídia, atividades de educação em direitos humanos, simulações de organismos internacionais com finalidades pedagógicas, instalações e intervenções artísticas, entre outras, são expressões de defesa e promoção de direitos humanos que podem - e devem - ser mescladas, misturadas e utilizadas de acordo com a natureza da organização, os membros envolvidos - suas possibilidades e habilidades -, assim como a violação de direitos humanos a ser combatida/prevenida.

\subsubsection{A ação coletiva}

As redes formadas por organizações da sociedade civil têm seu ponto de partida e de chegada na ação coletiva ${ }^{35}$. De acordo com Marisa Von Bülow, a ação coletiva tem como pré-condição a existência de redes da sociedade civil organizada, mas as redes são também resultado da ação coletiva. É um processo em que um elemento retroalimenta o outro, gerando uma poderosa sinergia. Assim, a autora propõe

definir redes sociais tanto como uma pré-condição da ação coletiva porque a ação é afetada pelas redes preexistentes dos atores - como um resultado da ação coletiva - porque os atores constroem novos vínculos que, por sua vez, são obstáculos (ou facilitadores) para ações futuras (VON BÜLOW, 2014, p. 18).

Como já foi referido, em geral há uma visão predominantemente estadocêntrica, tanto no plano político-social, quanto nas análises produzidas pela academia. Daí a importância da investigação de como ocorrem as alianças entre as organizações da sociedade civil, quais são seus compromissos em comum, que tipo de estratégias utilizam conjuntamente. Essa dissertação vem no sentido de contribuir para o preenchimento dessa lacuna. A abordagem proposta é interdisciplinar e dinâmica ${ }^{36}$, assim como é a realidade

35 Von Bülow (2014, p. 18) aponta sobre seu trabalho: “A abordagem defendida neste livro se baseia nessas críticas e propõe definir redes sociais tanto como uma pré-condição da ação coletiva - porque a ação é afetada pelas redes preexistentes dos atores - como um resultado da ação coletiva - porque os atores constroem novos vínculos que, por sua vez, são obstáculos (ou facilitadores) para ações futuras."

36 No mesmo sentido, Von Bülow (2014, p. 21) afirma que "Ao considerar a inserção simultânea dos atores em redes sociais e ambientes políticos no âmbito doméstico e além das fronteiras nacionais, este estudo tem 
política das organizações da sociedade civil e seus caminhos para a construção da ação coletiva transnacional.

Busca-se investigar justamente como ocorreu a formação da rede de organizações da sociedade civil que se juntaram para formar um caso para a Comissão Interamericano de Direitos Humanos, como foi escolhido o caso, como foi confeccionado, como a rede manteve-se ao longo do tempo, que impactos foram produzidos em função da demanda estar ativa no Sistema Interamericano de Direitos Humanos, entre outros aspectos igualmente relevantes para se compreender o fenômeno sob uma série de diferentes ângulos.

Como um grupo de organizações forma-se e mantém sua mobilização, apesar de todos os percalços que existem, principalmente ao se deparar com a complexidade intelectual, política e cultural, assim como com os altos custos - humanos e financeiros - de uma ação de mobilização coletiva? A resposta para essa pergunta pode ser obtida por inúmeras teorias que giram em torno da ação coletiva; essas teorias auxiliam a desvendar a realidade da mobilização transnacional.

Von Bülow (2014, p. 13) contextualiza a área das relações internacionais para as organizações da sociedade civil como um território cercado de incertezas. O cenário internacional exige uma vasta gama de habilidades e recursos. Do lado das organizações da sociedade civil, a disponibilidade para lidar com esse cenário é escassa, sendo que, geralmente, as organizações não possuem ferramentas para avaliar o tipo de expectativa que podem nutrir e/ou o tipo de resultado que podem esperar, a partir da confecção e execução de uma ação coletiva transnacional.

A incerteza e ambiguidade caracterizam as ações coletivas; tais características devem ser levadas em conta no momento de tomada de decisão das organizações da sociedade civil, no momento em que forem avaliar suas estratégias de trabalho. Um elemento importante para aferir os riscos de uma ação coletiva é justamente o conhecimento prévio (acúmulo de conhecimento) que há em relação a determinado espaço de atuação ou mesmo a determinada ação específica.

Assim, uma das variáveis é justamente o local de atuação, isto é, se há um acúmulo de conhecimento sobre esse espaço (quem são seus players, como se comportam, que tipo de atuação pode resultar em uma decisão $a$ ou $b$ etc). Nesse trabalho, explorar-se-á

presente não apenas a importância das teorias sobre movimentos sociais, da política comparada e das relações internacionais para a compreensão do ativismo transnacional, mas também o fato de que os limites entre essas disciplinas estejam se tornando cada vez mais porosos. A adoção de uma abordagem multidisciplinar é a maneira mais adequada de melhorar nosso entendimento da ação coletiva transnacional.” 
as possibilidades do Sistema Interamericano de Direitos Humanos, adiantando que a sociedade civil americana já conhece e de longa data reconhece os espaços oferecidos pela Comissão e Corte Interamericana de Direitos Humanos como privilegiados em termos de familiaridade e previsibilidade.

Ainda, interessante notar que as organizações também adquirem essa estabilidade a partir da formação da rede e do trabalho em conjunto. Esse é também um recurso importante para a criação e manutenção da ação coletiva, uma vez que essa só é possível num ambiente em que os resultados possam ser previstos (ou ao menos são esperados).

Cada Estado membro da Organização dos Estados Americanos possui uma política peculiar para o tratamento dos casos do Sistema, assim como cada sociedade civil nacional possui um determinado tipo de demanda que é trazida à tona. A partir desses elementos, as organizações da sociedade civil têm de, em que pese a estabilidade procedimental, utilizar sua criatividade na elaboração de estratégias para levar à frente novas demandas perante o SIDH e dar cumprimento às recomendações, medidas e sentenças no âmbito de cada país.

O problema da origem das organizações da sociedade civil e dos impactos de suas ações é o foco da presente dissertação, ou seja, quem são as organizações e como surgiu a rede de peticionários/representantes dos beneficiários no caso. Além da formação, importante explorar o funcionamento da rede de organizações. Afinal, como montaram e mantêm a sua ação coletiva?

Num segundo momento, importante avaliar os impactos gerados pela ação coletiva, a partir da análise de que obstáculos enfrentam, que tipo de estratégia adotam para enfrentar esses obstáculos e que resultados, de seu ponto de vista, foram alcançados.

A fim de explorar essas perspectivas, propõe-se a indagação do que consiste na ação transnacional coletiva. Para tanto, o livro "A batalha do livre comércio: a construção de redes transnacionais da sociedade civil nas Américas", de Von Bülow, oferece alguns caminhos.

Abordando o tema na perspectiva transnacional, a autora trabalha, num primeiro momento de aproximação, com as características das organizações, que são seus alvos (VON BÜLOW, 2014, p. 15). Assim, argumenta que quando as organizações querem influenciar negociações internacionais, buscam alianças fora de seus países, criando agendas 
em comum e lançando campanhas em conjunto com essas parceiras. Já outras, a depender de seus objetivos, criam estratégias que visam a influenciar as instituições domésticas. Outras, ainda, buscam modificar a postura dos Estados, enquanto outras elegem como seus destinatários a sociedade como um todo, servidores públicos, funcionários de organizações internacionais ou mesmo integrantes de outras organizações da sociedade civil.

Dentro dessa miríade de possibilidades, a autora adverte ser comum que os atores das organizações da sociedade civil não escolham trabalhar apenas com a escala doméstica, ou apenas com a global no momento de exploração das possibilidades da ação coletiva; mais comum é que ambos os espaços - internacional e nacional - sejam percorridos de maneira intermitente.

Com base nessas características, a autora propõe uma definição para a ação transnacional coletiva: "processo pelo qual indivíduos, grupos e/ou organizações não estatais se mobilizam conjuntamente em torno de temas, objetivos e alvos que vinculam as arenas doméstica e internacional” (VON BÜLOW, 2014, p. 15-16). Nessa definição, a palavra "mobilização" é central, o que vai ao encontro da escolha inicial da expressão utilizada por MacDowell Santos (2012).

Chama a atenção, contudo, a diferenciação entre a ação transnacional coletiva e o processo de internacionalização das organizações da sociedade civil. A ação coletiva não deve ser confundida com aquele processo mais amplo de internacionalização vivido pelas organizações desde os anos setenta, que culminou na organização e participação das organizações na Conferência Mundial de Direitos Humanos, em 1993.

Importante notar que uma série de tarefas realizadas pelas organizações da sociedade civil, tais como a constante troca de informações, coleta de abaixo-assinados, participação em congressos, seminários e reuniões internacionais e/ou regionais, visitas a países estrangeiros, confecção de relatórios, contato com agências de cooperação internacional e busca de financiamento junto a doadores internacionais, não constituem atividades que podem ser estritamente reconhecidas como ação transnacional coletiva quando consideradas individualmente. A ação coletiva é assim considerada em função da existência do compromisso de mobilização conjunta (VON BÜLOW, 2014, p. 16).

Outra análise importante é de que parte considerável da literatura de redes desconsidera o estudo do processo de formação e rompimento dos laços sociais que constituem, em última análise, o esforço coletivo, concentrando-se nas consequências das 
estruturas de redes para a ação específica (VON BÜLOW, 2014, p. 18). Tal enfoque deixa de lado uma parte importante do fenômeno, que se pretende explorar na presente dissertação: como organizações mantêm contato, trocam informações, chegam a consensos, pensam e desenvolvem a ação coletiva transnacional; além disso, que obstáculos encontram para realizarem tais tarefas e, ainda, que tipo de evento poderia levar ao rompimento de laços entre as organizações.

Essas questões são extremamente pertinentes, a fim de que se possa refletir sobre a prática das organizações, o que dá certo - e que poderá ser difundido e multiplicado - e o que não dá certo - e deverá ser prevenido e evitado. Considera-se, aqui, que do ponto de vista da práxis da sociedade civil, esses questionamentos apresentam-se como mais relevante do que àqueles que versam sobre modelos de redes e como esses colaboram, ou não, para uma ação coletiva.

A diferença entre as duas perspectivas é o ponto de partida: enquanto uma parte das experiências das organizações, a outra, das consequências das estruturas de redes para a ação específica.

Os diversos caminhos trilhados pelas organizações da sociedade civil para a mobilização transnacional do direito são resultado de múltiplas influências oriundas de dentro e fora de suas fronteiras nacionais. A dinâmica da ação coletiva pode ser explicada por meio de "processos específicos e mecanismos relacionais" (VON BÜLOW, 2014, p. 3032).

A interação entre os atores é elemento-chave para essa análise. O mapeamento da posição das organizações nas redes sociais, as origens dos vínculos entre as entidades e a investigação da transformação desses vínculos ao longo do tempo são expressão dessa interação, que deve avaliada com a finalidade de caracterização da ação coletiva.

Outro ponto estabelecido, e que será explorado posteriormente no momento em que se contextualizará a questão do sistema prisional, é a emergência de novas expressões de ação coletiva transnacional, que não podem ser investigadas de forma dissociada dos contextos políticos em que a sociedade civil se apresenta. A nova organização das escalas local e global significa uma reconfiguração do repertório organizacional disponível às organizações da sociedade civil ${ }^{37}$.

37 Sobre isso, Von Bülow (2014, p. 31-32) afirma o que se segue: "As relações de poder e as assimetrias não desaparecem nesse novo repertório organizacional. São parte integrante dessas novas iniciativas. Com frequência, porém, a formação de alianças transnacionais depende do papel de alguns atores que podem atuar como intermediários entre diferentes setores e temas, além de transpor fronteiras nacionais. Isso é mais 
Para o presente estudo, sobremaneira importante é a observação de que a ação coletiva transnacional pode retirar energia, tempo e recursos que poderiam ser investidos na esfera doméstica. Há, inclusive, uma percepção de que os gastos acima referidos são maiores no âmbito internacional do que no doméstico, para a consecução de um objetivo similar. Contudo, essa é apenas uma percepção; a complexidade para a realização de tal aferição é enorme. Pode-se afirmar que esse obstáculo consiste em uma fragilidade da ação coletiva transnacional ${ }^{38}$. As organizações da sociedade civil, muitas vezes, avaliam que podem investir menos recursos em uma demanda específica no âmbito doméstico, obtendo melhores resultados do que se investir nos planos internacional e doméstico ao mesmo tempo.

Esse debate não faz tanto sentido para a atuação no âmbito do SIDH, já que o SIDH é subsidiário ao sistema de normas e garantias internas do país. Além disso, a execução das decisões em sentido lato do SIDH tem de ser conduzida pelos Estados partes da Convenção. Ou seja, aqui existe um campo mais claro sobre os papeis do Estado nacional e as estratégias transnacionais.

Contudo, isso pode ser um elemento interessante para avaliação de uma organização no momento em que seus membros fazem a reflexão se devem ou não ingressar com uma demanda internacional. Tal avaliação, por óbvio, apenas faz sentido para as organizações que não possuem o ingresso de medidas internacionais para a proteção e promoção dos direitos humanos como escopo principal.

\subsection{O elemento "transnacionalidade"}

Debruçou-se, em algumas páginas, sobre o tema da mobilização. Agora, o foco é explorar o vocábulo "transnacionalidade", avaliando a possibilidade de significados que possam agregar ao debate do tema posto. Para tanto, na continuidade do diálogo acima travado, depara-se com debates sobre globalização, cidadania global e/ou subalterna, ação coletiva transnacional, assim como os espaços institucionais de direitos humanos relevante nos casos de iniciativas de longo prazo."

38 Von Bülow (2014, p. 32) avalia que os "Mecanismos relacionais como extensão, supressão, difusão e transformação podem fortalecer vínculos entre aliados internacionais muito diferentes entre si, mas também podem levar a um declínio da ação coletiva na esfera doméstica, porque: a atenção e os recursos políticos diluem-se em vez de se concentrarem em demandas específicas, as principais demandas são por vezes ignoradas e novos tipos de organizações e ideias têm de ser adaptados a diversas realidades sociais e políticas. Pelos mesmos motivos, acordos transnacionais entre OSC's costumam ser frágeis e vigorar por apenas breves períodos de tempo". 
internacionais - e as oportunidades políticas que apresentam.

A transnacionalidade propõe, em função da sua própria nomenclatura, um debate sobre o conceito de nação. O vocábulo "trans" denota a ideia de "para além de". Grosso modo, significa "para além da nação". Em algumas leituras, o conceito de transnacionalização ${ }^{39}$ é apresentado com a finalidade de apontar o processo de transição entre o plano internacional - entre nações - para transnacional - para além das nações.

A proposta que aqui se apresenta é de que, nesse quadro transitório, o termo “internacional" tinha em sua centralidade o conceito de nação; entretanto, a expressão "transnacionalidade" aponta para um foco difuso, em que há uma multiplicidade de atores, instituições e ordens jurídicas que trabalham em torno de questões com base em um diálogo político, econômico, social e jurídico, que é travado para além das fronteiras nacionais.

Passando-se para o terreno dos direitos humanos, ressignificando a expressão e tomando-a para o seu uso específico, pode-se afirmar que a ideia de transnacionalidade qualifica a ideia de internacional, visto que, nesta, ainda se fica preso à centralidade do ente estatal, enquanto naquela, abre-se espaço para atores diversos, oportunidade teórica para a devida reflexão sobre o protagonismo da sociedade civil organizada, assim como das vítimas de direitos humanos, no cenário mundial.

\subsubsection{A globalização e o cosmopolitismo}

\section{As diferentes narrativas sobre a globalização.}

Compreende-se, aqui, que a globalização, da mesma forma que a transnacionalidade, tem em sua origem num fenômeno econômico ${ }^{40}$, depois, espraiando-se

39 Paralelamente, Marcelo Neves (2014b, p. 208) aponta o fenômeno do transconstitucionalismo, que suplantaria inclusive o da transnacionalização: "O transconstitucionalismo não toma uma única ordem jurídica ou um tipo determinado de ordem como ponto de partida ou ultima ratio. Rejeita tanto o estatalismo quanto o internacionalismo, o supranacionalismo, o transnacionalismo e o localismo como espaço de solução privilegiado dos problemas constitucionais. Aponta, antes, para a necessidade de construção de 'pontes de transição', da promoção de 'conversações constitucionais', do fortalecimento de entrelaçamentos constitucionais entre as diversas ordens jurídicas: estatais, internacionais, transnacionais, supranacionais e locais." Da perspectiva do presente trabalho, não se faz necessário ingressar nesse tema, já que o conceito de transnacionalidade basta para descrever, em termos não apenas jurídicos como no caso do transconstitucionalismo, o fenômeno que se busca explorar. Contudo, não há um rechaço da ideia de pontes e de conversações entre as ordens jurídicas, muito pelo contrário: a transnacionalidade aqui reclamada baseia-se justamente na ideia de diálogo entre atores, instituições e ordens jurídicas, para a consecução do objetivo de defesa e promoção dos direitos humanos.

40 Sidney Tarrow (2009, p. 225) contextualiza, assim, a origem da globalização: “(...) por volta do fim da II Guerra Mundial, começou a se desenvolver uma economia global, acompanhada da liberalização do comércio 
para as outras dimensões da vida humana, como a política, a social e a jurídica, entre outras. A referida mudança econômica, juntamente com o "surgimento de estruturas públicas de comunicação que aproximam ainda mais o centro e a periferia do sistema mundial" (TARROW, 2009, p. 225-226), foram decisivos para a formulação do conceito de globalização, assim como para seus primeiros contornos de ordem prática.

Um efeito reputado à globalização é a mudança de consciência política e percepção que as pessoas possuem, de acordo com o território geográfico em que se encontram ${ }^{41}$, de sua realidade econômica, política e social. As relações econômicas, assim como a revolução tecnológica e seu efeito sobre as formas de comunicação, foram os dois fatores preponderantes dessa transformação de consciência a partir do pertencimento dos indivíduos em seus espaços territoriais.

$\mathrm{Na}$ presente pesquisa, não se pretende explorar todos os significados da globalização, nem mesmo, como intentam alguns, propor a reversão desse processo ${ }^{42}$. Trabalha-se com a ideia de globalização como um fenômeno que possui muitos significados; ressalta-se, entretanto, que se deve dar atenção a esses significados, o que é possível a partir da leitura crítica em relação ao processo.

Com efeito, Márcia Nina Bernardes (2014, p. 290) aponta que a "globalização parece ter destruído a ordem mundial, sem ter inaugurado uma nova". Apoiando-se em Zygmunt Bauman (1999), afirma que houve uma passagem do uso do termo "universalização" pelo "globalização", o qual impregnou os discursos nas mais variadas áreas. A ideia de universalização ${ }^{43}$, tão ligada aos direitos humanos e à gênese de sua normativa internacional, foi substituída pela de globalização, dando mais força à ideia de resultados práticos que ocorrem em uma escala global, principalmente no plano econômico e

internacional e do surgimento de uma nova hegemonia política".

41 Tarrow (2009, p. 226) aponta que "A expansão dos mercados mundiais e das comunicações globais aproxima os cidadãos do norte e do oeste dos cidadãos do leste e do sul, tornando os primeiros mais cosmopolitas e os últimos mais conscientes de sua desigualdade em relação a eles".

42 Ao tratar do posicionamento das organizações da sociedade civil sobre a globalização, Von Bülow (2014, p. 38) aponta que "Embora alguns desejem desglobalizar o mundo, restituindo os poderes de tomada de decisão a instituições políticas nacionais, outros querem mais globalização em certas arenas e áreas temáticas. Com frequência, atores da sociedade civil, tanto do Norte quanto do Sul, acham que são melhores advogados da soberania e dos interesses de seu país do que seus próprios governos. Seu principal objetivo é fortalecer os Estados nacionais, não enfraquecê-los. Além disso, muitas ONGs, movimentos sociais e sindicatos veem com desconfiança qualquer tentativa de criar arenas de sociedade civil global que minem sua própria autonomia e flexibilidade." Não esquecendo que o livro da autora aborda as organizações que trabalham com questões envolvendo livre comércio, e não direitos humanos.

43 Segundo Bernardes (2014, p. 290), a ideia de universalização "estava associada a conceitos como 'civilização', 'desenvolvimento' e 'consenso'. O termo globalização, no entanto, não reteve nenhum desses significados. Ele não denota projetos intencionais, mas sim efeitos globais de processos supostamente incontroláveis e imprevisíveis." 
da comunicação.

Assim, há a percepção de que os Estados estão se adaptando a essa nova realidade, em que perdem parte de sua força e soberania para grandes empresas, assim como, ao mesmo tempo, os indivíduos devem aceitar as condições impostas para sua existência pelas novas regras da globalização ${ }^{44}$. Nesse sentido, o fenômeno da globalização teria um significado mais profundo para a humanidade, ao produzir um sentimento geral de indeterminação, dispersão, falta de controle e automação dos processos globais, com a permanente sensação de que o sujeito encontra-se à deriva (BAUMAN, 1999, p. 68-69).

A globalização, vista a partir dessa perspectiva, apresenta um quadro pessimista $^{45}$, em que o fenômeno produz consequências humanas atrozes por força de um projeto que visa, em última análise, acelerar e aprimorar os mecanismos do sistema capitalista, ao invés de se constituir como uma plataforma de promoção e defesa de direitos humanos.

Em concordância, grosso modo, com essa visão, Rodríguez-Garavito e Santos (2005, p. 2) afirmam que há uma narrativa convencional sobre a globalização e as transformações legais globais que ocorrem de cima para baixo, fluindo no sentido da difusão dos modelos econômicos e legais desde o Norte global para o Sul global.

Estaria em curso, portanto, a construção de uma narrativa hegemônica sobre a globalização, constituída por processos de cima para baixo, no sentido de que as instituições impõem os processos a pessoas e/ou grupos de pessoas. Da mesma forma, tal narrativa traz a imposição da perspectiva do Hemisfério Norte, tendo como destinatário o Hemisfério Sul. Ainda se encontra, aqui, a colonialidade ${ }^{46}$, nos processos de globalização, mas também na

44 Acerca disso, Bernardes (2014, p. 290) afirma que "Estados parecem estar se adaptando a imperativos do mercado global que não podem controlar, em vez de forjar suas próprias políticas econômicas. Tornar-se globalizado não é algo que possamos ou queiramos fazer, mas é algo que está acontecendo com todos nós".

45 Bauman (1999, p. 64) esclarece que, nesse cenário, as estruturas, mesmo que imperfeitas, porém, confiáveis, dos Estados, estão sendo corroídas pela transnacionalidade, aqui em uma conotação pejorativa, que possui relação direta com o poder econômico - que resulta em poder político - sem precedentes das empresas transnacionais: "Uma vez que as nações-estados continuam sendo as únicas estruturas para um balanço e a $\mathrm{s}$ únicas fontes de iniciativa política efetiva, a "transnacionalidade" das forças erosivas coloca-as fora do reino da ação deliberada, proposital e potencialmente racional. Como tudo o que elide essa ação, tais forças, suas formas e ações são ofuscadas na névoa do mistério; são objetos de adivinhação e não de análise confiável.”

46 Apesar de não possuir relação direta com meu tema de pesquisa, é necessário indicar que o termo colonialidade aqui aplicado encontra-se em consonância com as propostas dos teóricos descoloniais, no sentido da representação de um padrão de classificação mundial da ordem capitalista global. Segundo Anibal Quijano (2014), um dos maiores expoentes dessa teoria, esse padrão, constituído em tempos coloniais (desde a colonização da América, mais especificamente), caracteriza-se pela hierarquização racial das subjetividades e pela constituição das relações humanas em torno de categorias binárias, como branco e não branco, primitivo e civilizado, tradicional e moderno, superior e inferior. Dessa forma, explica o autor, estabelecem-se as categorias consideradas positivas à Europa (e aos países do "norte" global), assim como as consideradas 
construção da narrativa sobre a globalização.

A partir desse ponto de partida, os autores trabalham com a importância da construção de narrativas sobre o direito e a globalização que expressem a perspectiva de baixo para cima e do Sul para o Norte, a partir de dados empíricos, buscados junto aos movimentos sociais e às organizações da sociedade civil (RODRÍGUEZ-GARAVITO \& SANTOS, 2005, p. 4).

Ao se tratar de forma crítica o fenômeno do Estado, no momento em que, por exemplo, questiona-se a razão pela qual a sociedade civil não mais figura como protagonista da vida política, não se está, em momento algum, argumentando a favor de um papel mínimo ou minimalista de Estado ${ }^{47}$. Muito pelo contrário: o Estado deve ser forte, operativo e dar respostas eficientes às suas populações; contudo, as populações é que devem reger, a partir de uma perspectiva emancipatória de Estado, quais devem ser os caminhos que o Estado deve tomar e seguir, dentro da ideia de radicalidade democrática.

Essa é uma das armadilhas de um debate como esse: ao se abraçar a globalização, ao menos o que a globalização possui de positivo para a sociedade civil, para os direitos humanos e para a democracia, não se está aquiescendo com a ideia de que os Estados devam perder completamente sua soberania e devam ficar à mercê do mercado, na radicalidade do capitalismo.

As proposições não se confundem: os Estados nacionais podem ser fortalecidos frente às empresas transnacionais, ao mesmo tempo em que podem - e devem - fortalecer suas políticas públicas ${ }^{48}$, de acordo com os parâmetros internacionais de direitos humanos

negativas, aos demais povos do mundo. A partir da colonialidade do poder, do ser e do saber, foi possível consolidar e expandir o capitalismo, produzindo-se uma divisão global e racial do trabalho e a emergência do colonial/moderno sistema-mundo (QUIJANO \& WALLERSTEIN, 1992). Para aprofundamento sobre colonialidade, ver Rita Segato (2013).

47 O Estado mínimo ou minimalista é a resposta usual da direita brasileira para os problemas orçamentários existentes no país, o que também não é fenômeno apenas no Brasil, já que as chamadas políticas de austeridade atingem, hoje, países europeus como a Grécia, a Espanha e Portugal. O enxugamento da máquina estatal aparece, nos discursos políticos, como uma solução, quando na verdade só reforça, dentro do Brasil, as enormes desigualdades sociais existentes: "Para tentar encontrar uma resposta a essa questão é preciso identificar o projeto hegemônico das elites brasileiras. É um projeto que busca a modernização conservadora, priorizando as partes já mais avançadas do país. Busca ampliar a inserção competitiva de nossos nichos dinâmicos, esquecendo o que considera 'o resto'. Um projeto que tende a desconsiderar o grave quadro de desigualdade social que o país tem. Esse é o equívoco da elite brasileira achar que pode fazer do Brasil uma grande potência com o tamanho da desigualdade social que nós temos. E não pode. Basta ver a crise social instalada nas principais capitais do país." (ARAÚJO, 2012, p. 18). Portanto, a solução, no Brasil, não é tornar o Estado mínimo ou minimalista, mas, sim, torná-lo orientado para a extinção das desigualdades sociais e para a promoção e defesa dos direitos humanos, o que demanda fortes e pujantes políticas públicas sociais e, por consequência, o fortalecimento do Estado.

48 Tânia Bacelar de Araújo (2012, p. 19), ao referir-se à dinâmica transnacional das grandes empresas e à resposta dos Estados nacionais para enfrentar os impactos regionais e localizados seletivos da globalização, 
emitidos pelos órgãos protetivos supranacionais.

A transnacionalidade abre espaço para os discursos e práticas de direitos humanos porque favorece a relação entre o direito nacional e o direito internacional - e todas as instituições que o produzem, interpretam e forçam sua aplicação. Os parâmetros do Sistema Interamericano de Direitos Humanos somente são obrigações concretas e palpáveis para os Estados em função de que sua aplicação ocorre no âmbito doméstico, por meio do direito nacional e de suas instituições que o aplicam e o garantem. Assim, conforme Jürgen Habermas (2012, p. 29-31)

Por um lado, os direitos humanos só podem adquirir a validade positiva de direitos fundamentais em uma comunidade particular - primeiro, no interior de um Estado nacional. Por outro lado, sua pretensão de validade universalista, que aponta para além das fronteiras nacionais, só pode ser resgatada em uma comunidade cosmopolita inclusiva. Essa contradição só pode ser resolvida em uma sociedade mundial constituída democraticamente (que não precisa ela mesma assumir qualidades estatais). Desde o início existe uma tensão dialética entre os direitos humanos e os direitos dos cidadãos, que sob circunstâncias históricas favoráveis pode desencadear uma 'dinâmica de abrir portas' (Lutz Wigert) (grifo meu).

Considera-se, aqui, que a dinâmica de abrir portas nada mais é que essa função relacional que há entre o direito nacional e o internacional, já que este expande aquele. Da mesma forma, necessita-se do direito nacional para que o direito internacional possa ser aplicado e garantido em casos concretos da vida cotidiana das pessoas que são protegidas pelo direito internacional dos direitos humanos.

Ao ater sua análise primordialmente nos instrumentos estatais de proteção dos direitos humanos, Habermas (2012) expressa veementemente que não o faz desconsiderando que a origem de todo esse aparato encontra-se na luta travada pela sociedade civil em prol dos direitos humanos ${ }^{49}$.

Conforme apresentado anteriormente, Habermas argumenta que há uma tensão

afirma que "Não é à toa que o pensamento neoliberal ataca com força o papel das políticas nacionais, propondo o Estado mínimo ou supervalorizando o papel de políticas local".

49 Sobre isso, Habermas (2012, p. 31) afirma que "Isso não quer dizer que a intensificação da proteção dos direitos humanos no interior dos Estados nacionais e sua ampliação global mundo afora teria sido possível sem os movimentos sociais e as lutas políticas, sem a oposição corajosa à opressão e degradação. A luta para impor os direitos humanos continua não apenas em nossos próprios países como também, por exemplo, na China, na África ou na Rússia, na Bósnia ou em Kosovo. Cada deportação dos que buscam asilo que por ocorre detrás das portas fechadas de um aeroporto, cada navio naufragado com refugiados que fogem da pobreza na rota mediterrânea entre a Líbia e a ilha de Lampedusa, cada tiro na cerca da fronteira mexicana coloca uma questão inquietante aos cidadãos do Ocidente." 
dialética entre direitos humanos e direitos do cidadão - estes que se poderiam denominar de direitos fundamentais.

Com base nessa mesma lógica, poder-se-ia traçar um paralelo - com essa mesma tensão - em relação à positivação/normatização dos direitos humanos e sua prática. Como na atualidade, os direitos humanos foram positivados, tornando-se, ao utilizar a expressão do autor, muitas vezes direitos do cidadão - fenômeno em que o direito internacional impõe seu parâmetro de direitos humanos e, na sequência, os Estados adotam medidas internas que estejam de acordo com ditos parâmetros - mesmo os realistas ${ }^{50}$ não podem mais negar a existência dos direitos humanos.

Contudo, alerta para o problema da traição do "impulso utópico" ${ }_{51}$. Mesmo que se trabalhe com a ideia de direitos humanos enquanto relacionados à vida na comunidade política, o autor adverte que tal entendimento não pode ofuscar o mandato de que "cada um seja respeitado em sua dignidade humana como sujeito de direitos iguais" (HABERMAS, 2012, p. 35).

E adverte, ainda, sobre o perigo de tornar direitos humanos uma questão de

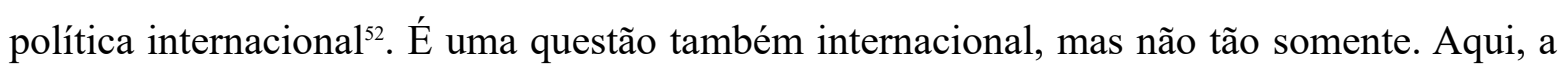
transnacionalidade se faz sentir, já que os direitos humanos somente existem - no sentido forte da palavra, a fim de poderem ser interpretados e garantidos como tal - dentro da relação nacional-internacional. O autor afirma, pois, que

Esse minimalismo esquece que a contínua relação tensa, interna ao Estado, entre os direitos humanos universais e os direitos particulares dos cidadãos é o fundamento normativo para a dinâmica internacional. Quando não consideramos esse vínculo, a difusão global dos direitos humanos exige uma fundamentação específica. A isso serve o argumento de que nas relações internacionais as obrigações morais entre os Estados (e cidadãos) emergem primeiro da crescente integração sistêmica de uma sociedade

50 Acerca disso, Habermas (2012, p. 34) esclarece a força que possuem os direitos humanos na atualidade: "Uma vez que não é mais realista rejeitar completamente, na esteira de Carl Schmitt, o programa dos direitos humanos, cuja força subversiva se infiltrou, nesse meio-tempo, nos poros de todas as regiões do mundo (...)" $51 \mathrm{O}$ que estaria acontecendo, segundo Habermas (2012, p. 34-35) é que "A crítica desmascaradora direta é substituída por um deflacionamento brando dos direitos humanos. Esse novo minimalismo acaba relaxando a força dos direitos humanos, ao separá-los de seu impulso moral essencial, a saber, a proteção da dignidade igual de cada um" (grifo meu).

52 Continua Habermas (2012, p. 35-36): "Esse minimalismo esquece que a contínua relação tensa, interna ao Estado, entre os direitos humanos universais e os direitos particulares dos cidadãos é o fundamento normativo para a dinâmica internacional. Quando não consideramos esse vínculo, a difusão global dos direitos humanos exige uma fundamentação específica. A isso serve o argumento de que nas relações internacionais as obrigações morais entre os Estados (e cidadãos) emergem primeiro da crescente integração sistêmica de uma sociedade mundial cada vez mais interdependente. Desse ponto de vista, as pretensões de inclusão resultam primeiro da dependência recíproca em interações que ocorrem faticamente." 
mundial cada vez mais interdependente. Desse ponto de vista, as pretensões de inclusão resultam primeiro da dependência recíproca em interações que ocorrem faticamente (HABERMAS, 2012, p. 35-36).

\section{Por um cosmopolitismo crítico.}

O cosmopolitismo traz em seu bojo a ideia de que os cidadãos podem extrapolar a sua relação com seus Estados e, também, serem cidadãos do mundo. Habermas (2012) propõe, em seu livro "Sobre a constituição da Europa", o cosmopolitismo como modelo para aperfeiçoamento da democracia, incrementada pela criação de instituições políticas supranacionais, que serviriam de espaço político para os cidadãos cosmopolitas.

Mesmo trazendo o exemplo da União Europeia, objeto diverso do que versa a presente dissertação, é possível extrair algumas ideias que podem ser aproveitadas, quando devidamente contextualizadas. Assim, destaca-se aqui a expressão "construção de capacidades de ação política para além dos Estados nacionais”, proposta por Habermas (2012) nos seguintes termos

\footnotetext{
"Pretendo, com meus recursos, fazer a tentativa de tirar do caminho certos bloqueios mentais que ainda persistem a respeito de uma transnacionalização da democracia. Para isso situo a unificação europeia no contexto de longo prazo de uma juridificação democrática e de uma civilização do poder estatal. A partir dessa perspectiva, deve se tornar claro que a pacificação das nações beligerantes - ou seja, o objetivo que depois da Segunda Guerra Mundial não motivou apenas a fundação das Nações Unidas, mas também a unificação europeia - formou a base inicial para um objetivo mais abrangente, a saber, a construção de capacidades de ação política para além dos Estados nacionais. Há muito tempo que a constitucionalização do direito das gentes não está mais orientada apenas àquela pacificação que se encontrava também no início do desenvolvimento da União Europeia. A implosão das ilusões neoliberais promoveu a concepção segundo a qual os mercados financeiros, principalmente os sistemas funcionais que perpassam as fronteiras nacionais, criam situações problemáticas na sociedade mundial que os Estados individuais - ou as coalizões de Estados - não conseguem mais dominar" (grifo meu) (HABERMAS, 2012, p. 4-5).
}

Tal expressão conjuga-se com as ideias em torno da transnacionalidade (para além dos Estados nacionais) que se debate nesse capítulo, já que na configuração proposta não se prescinde do Estado, assim como há a preocupação com a construção das capacidades (superação dos bloqueios mentais), o que indica que tal transformação social tem relação com educação e cultura. Ou seja, a transnacionalidade aqui não é apenas um fenômeno que 
se está testemunhando, mas, sim, um projeto de vida política - o cosmopolitismo -, que pressupõe engajamento e reflexão. Mais adiante, Habermas (2012, p. 5) afirma que "a comunidade internacional dos Estados tem de progredir para uma comunidade cosmopolita de Estados e dos cidadãos do mundo" ${ }^{53}$.

Também Rodríguez-Garavito e Santos (2005, p. 13) propõem um novo tipo de cosmopolitismo, que considere a relevância das diferenças culturais existentes entre os povos e os indivíduos, principalmente levando-se em conta que o desenho das instituições e da normativa de direitos humanos tem base na tradição do Ocidente e do Norte $^{54}$. A partir de uma perspectiva crítica, esse cosmopolitismo constitui-se em um projeto contrahegemônico, que busca subverter a lógica posta de hierarquias e fronteiras entre Estados.

A proposta é tomar posse da expressão cosmopolitismo, levando em conta quem precisa dele. A resposta para a pergunta é muito direta: quem quer que seja vítima de intolerância ou discriminação local precisa de tolerância e apoio além-fronteiras, assim como quem vive na miséria ou quem não é cidadão ou é cidadão de segunda classe de alguma nação. Para essas pessoas, precisa-se de um novo tipo de cosmopolitismo, o cosmopolitismo subalterno ${ }^{55}$.

Fala-se, portanto, de uma globalização contra-hegemônica, que se constitui em um projeto plural, com muitas possibilidades de comunicação, compreensão e cooperação entre diferentes grupos que lutam pelos direitos humanos. Essa possibilidade política é um ponto de partida, e não de ponto de chegada, assim denominada por Santos (2003) de cosmopolitismo subalterno ou cosmopolitismo dos oprimidos ${ }^{56}$.

53 E continua: "Essa pretensão cosmopolita significa que o papel dos direitos humanos não pode se esgotar na crítica moral das relações injustas de uma sociedade mundial altamente estratificada. Os direitos humanos dependem de sua incorporação institucional em uma sociedade mundial constituída politicamente." (HABERMAS, 2012, P. 5).

54 Acerca disso, afirmam Rodríguez-Garavito e Santos (2005, p. 13-14): "More often than not, however, cosmopolitan political and legal projects have been as Western- or Northern-centric and exclusionary as the global designs they oppose. For instance, human rights institutions and doctrines, with their Western roots and liberal bent, have oftentimes been blind to non-Western conceptions or human dignity and collective rights that hold out the prospect for an expanded, cosmopolitan conception of rights."

55 Rodríguez-Garavito e Santos (2005, p. 14) desenvolvem sua ideia de cosmopolitismo subalterno da seguinte forma: ""Instead of discarding cosmopolitanism as just one more variety of global hegemony, we propose to revise the concept by shifting the focus os attention to those who currently need it. Who needs cosmopolitanism? The answer is straightforward: whoever is a victim of local intolerance and discrimination needs cross-boarder tolerance and support; whoever lives in misery in a world of wealth needs cosmopolitan solidarity; whoever is a non- or second-class citizen of a country or the world needs an alternative conception of national and global citizenship. In short, the large majority of the world's populace, excluded from top-down cosmopolitan projects, needs a different type of cosmopolitanism. Subaltern cosmopolitanism, with its emphasis on social inclusion, is therefore of an oppositional variety."

56 Santos (2003, p. 28) estabelece as bases para a sua proposta de cosmopolitismo: “A globalização contrahegemônica é, por isso, um projecto plural, nisso residindo simultaneamente a sua força e a sua fraqueza. Tal 
Pode-se, assim, conjugar as proposições de Habermas (2012), RodríguezGaravito e Santos (2005) e Santos (2003) para se ressaltar a necessidade do cosmopolitismo. A perspectiva crítica que Rodríguez-Garavito e Santos apontam é fundamental, principalmente quando se leva em conta quem são os atores - se falam do sul ou do norte - e o papel que se exerce no contexto global. Portanto, necessário se faz observar esses elementos do "cosmopolitismo subalterno" para que se reflita sobre como esse discurso do cosmopolitismo pode funcionar a favor dos direitos humanos, e não contra eles.

Por outro lado, num outro extremo, há autores que sustentam que há um "pensamento único localista", que seria uma forma de perceber a globalização como um processo em que as escalas intermediárias entre local e global perderiam sentido (BRANDÃO, 2012, p. 29). Nesse caminho, a escala "nacional" perderia espaço, visto que não teria mais razão para existir ${ }^{57}$.

Ainda sobre o localismo enquanto pensamento único, o autor trabalha com a ideia de que nenhuma escala - global, regional, nacional, local - é boa ou ruim. Necessário é discutir os problemas em si, sua espacialidade e que políticas públicas são mais adequadas para se chegar a uma solução, independentemente da escala. Assim, Carlos Brandão (2012) propõe que se discuta, a partir de problemas específicos, quais escalas são mais adequadas para se chegar a soluções:

Entendo que o enfrentamento dessa visão, hoje hegemônica, passaria pela reflexão crítica e pela discussão de propostas alternativas e pelo tratamento adequado da articulação de todas as escalas geográficas. Nenhuma escala per se é boa ou ruim. É preciso discutir a espacialidade dos problemas e implementar políticas levando em consideração a escala específica desses problemas, mas em um contexto em que esteja presente um projeto nacional de desenvolvimento. Penso que, ao contrário daquelas visões, as escalas 'intermediárias' ganham novo sentido e importância nessa fase do capitalismo (BRANDÃO, 2012, p. 36).

pluralidade e diversidade não eliminam a possibilidade de comunicação, de compreensão mútua e de cooperação entre as diferentes lutas. De facto, o potencial e a viabilidade da globalização contra-hegemônica giram, exactamente, à volta dessa possibilidade. No entanto, tudo o que for conseguido graças à colaboração entre movimentos e organizações progressistas será menos o resultado de um ponto de partida comum do que de um comum ponto de chegada. A este feixe de projetos e lutas chamo de cosmopolitismo subalterno ou cosmopolitismo dos oprimidos."

57 Carlos Brandão (2012, p. 29) afirma que se encontra cristalizado um consenso em torno do que chama de "pensamento único localista": "Grande parte da literatura aborda, e as políticas 'públicas' implementam, ações orientadas, em parte ou no todo, por essas concepções teóricas, acolhendo vulgaridades analíticas e simplismos ideológicos que afirmam que as escalas intermediárias entre 'o local' e 'o global' estão perdendo sentido. Sobretudo, assumem que pensar a escala nacional e as questões estruturais é retrógrado". 
Transpondo esse debate para os direitos humanos, pode-se chegar a conclusões similares: o que se busca, em última análise, é a obstrução e/ou prevenção de uma violação de direitos humanos. A multiplicidade de escalas, e seu uso a partir do problema concreto que existe para resolução, pode ser uma resposta para esse desafio.

Ao se pensar no Sistema Interamericano de Direitos Humanos enquanto um sistema - um conjunto de órgãos articulados em função de tarefas coordenadas sob objetivos comuns - presume-se, de antemão, que os processos, ali em trâmite, são internacionais. Mesmo quando a violação de direitos humanos, objeto de reparação/prevenção de novas formas de sua violação, ocorre em um único país - como o Brasil -, sendo a vítima um nacional daquele Estado - um brasileiro -, e, ainda, com peticionários exclusivamente nacionais, o elemento internacional impõe-se pelo fato do caso ter chegado a uma instância internacional, no caso, a interamericana.

Nesse âmbito, a aplicação do direito que será realizada será a do direito internacional dos direitos humanos, mais especificamente, dos parâmetros interamericanos de direitos humanos, que foram e estão sendo construídos com base primordial na experiência interamericana de resolução de casos de violações de direitos humanos junto ao sistema de casos e petições do Sistema Interamericano.

Em suma, mesmo que a totalidade de vítimas e peticionários do caso sejam nacionais do Estado violador, tem-se a aplicação do Direito Interamericano dos Direitos Humanos são marcadas, ao extremo, dentro de estruturas interamericanas, pelos elementos da transnacionalidade. Pode-se afirmar, portanto, que em qualquer caso que tramitar no SIDH haverá o elemento da transnacionalidade, independentemente das características das vítimas e das organizações da sociedade civil que articularem e demandarem junto ao caso.

\section{2. 2. A ação coletiva transnacional}

Voltando ao assunto da ação coletiva, far-se-á a reflexão desde a perspectiva de seu caráter transnacional.

Acerca disso, Von Bülow (2014) trabalha com a ideia de "caminhos para a transnacionalidade". Essa fluidez da expressão "caminhos" significa, dentro de sua obra, que a ação coletiva está em constante construção pelas organizações da sociedade civil. A variedade de objetivos, estratégias e discursos, que mudam ao longo do tempo, pode ser 
compreendida por meio da ideia de rotas construídas pelas organizações da sociedade civil para vincular debates e ações através das escalas local, nacional e internacional.

Segundo a autora, portanto, a novidade apontada não é o surgimento de uma sociedade civil global, mas sim uma crescente internacionalização de organizações, seja por conta de objetivos, estratégias ou discursos que são compostos por elementos internacionais. Em sua maioria, as organizações mantêm-se enraizadas na escala local ou nacional; o que ocorre é que vão se utilizar, cada vez mais, de elementos do plano internacional na elaboração de seu discurso e de suas atividades, o que denomina de "articulação de diferenças por meio de escalas geográficas" (VON BÜLOW, 2014, p. 17-8).

A mobilização, de acordo com a escala utilizada, pode ter um impacto maior ou menor, de acordo com o objetivo da organização. Portanto, conforme a autora, coloca-se em debate a questão sobre qual escala produz maior eficácia ${ }^{58}$. Parte da resposta, quando se depara com uma violação de direitos humanos, estava no ponto anterior: a depender do tipo de violação e de uma série de variáveis, pode-se chegar a uma ou outra resposta; contudo, algo é certo: deverá haver uma multiplicidade de escalas envolvidas na resposta a fim de que uma ação coletiva tranasnacional, no âmbito de direitos humanos, tenha um impacto $\operatorname{positivo~}^{59}$.

O interessante para a presente pesquisa também é observar que há diferenças quanto à compreensão do elemento da transnacionalidade. Von Bülow $(2014$, p. 16) ressalta que sua proposta de ação coletiva transnacional não exclui "iniciativas que buscam mudar políticas e instituições domésticas", diferentemente, por exemplo, de Della Porta e Tarrow (2005, p. 7) que, ao centrar sua análise em redes, atores e campanhas internacionais, não abrem espaço para observar situações em que um desses elementos (redes, atores ou campanhas) provocam impactos nos âmbitos domésticos.

Para o presente objeto de pesquisa - uma demanda sobre violação de direitos humanos, em um presídio de Recife, proveniente de uma rede de organizações da sociedade

58 Para a autora, "Uma questão-chave na literatura sobre transnacionalismo é: em qual escala é mais provável que a mobilização seja eficaz? Para alguns autores, dado o enfraquecimento da autoridade e do poder dos Estados nacionais, a escala global ganhou importância. De acordo com essa perspectiva, é um equívoco que atores da sociedade civil tenham como foco as reivindicações de soberania nacional. Para outros, os Estados ainda detêm um poder considerável e, por conseguinte, ações nas escala nacional e local têm mais chances de sucesso" (VON BÜLOW, 2014, p. 37-38).

59 A autora usa a expressão "eficácia"; entretanto, como no Direito a palavra "eficácia" possui um conceito específico e reduzido, procuro utilizar a expressão "impacto" para designar os resultados produzidos pela mobilização transnacional do direito em relação a violações/questões/problemas que envolvam direitos humanos. 
civil, com base no direito internacional dos direitos humanos e como destinatária a Comissão Interamericana de Direitos Humanos - a proposição de Della Porta e Tarrow não faz sentido.

O que se pretende é justamente avaliar quais são os impactos no âmbito doméstico - que é onde reside a violação e, portanto, a violação a ser enfrentada - dessa ação coletiva transnacional que foi levada a cabo - e continua sendo - pela rede de organizações que se articularam para isso.

Um alerta encontrado no livro de Von Bülow faz-se necessário para a presente investigação. A autora recomenda cautela no estudo da ação coletiva transnacional a partir do estudo de casos, como tem feito a literatura da área ${ }^{60}$. O resultado dessa orientação é uma visão fragmentada sobre o fenômeno da ação coletiva transnacional, além de tender a produzir análises otimistas em relação às ações e seus impactos.

Para além disso, o debate sobre a ação coletiva transnacional pode jogar luz sobre o processo de formação de alianças entre as organizações da sociedade civil, no momento da criação da rede. Nesse sentido, vale questionar como atores tão diferentes, que atuam em planos distintos, com diversas compreensões políticas, sociais, econômicas e, da mesma forma, de direitos humanos, empreendem um esforço conjunto para atuar sobre um mesmo problema? O que a transnacionalidade contribui - ou mesmo atrapalha - nesse processo?

Antes de seguir com as reflexões suscitadas pelas indagações apresentadas, fazse importante referir-se ao conceito de "formação de alianças" - o qual será útil para a apreciação da realidade trazida pelo estudo de caso -, que nada mais é do que o "processo de criação de espaços comuns entre atores diferentes, que negociam o significado de empreendimentos conjuntos e elaboram estratégias em comum" (KECK \& SIKKINK, 1998, p. 3).

Dessa forma, no âmbito da ação coletiva transnacional, encontra-se consensuado que há maior viabilidade de alianças para além das fronteiras quando essas não possuem uma estrutura permanente - equipes, escritórios, equipamentos etc - focada em demandas e

60 Propõe Von Bülow (2014, p. 41) que deve se ter uma visão crítica sobre o fenômeno da ação coletiva sob o prisma do transnacionalismo, já que "uma parte importante da análise empírica oferecida pela literatura sobre o transnacionalismo se baseia em estudos de casos de campanhas temáticas e protestos específicos. Embora essa literatura tenha nos ensinado muito do que sabemos sobre transnacionalismo, o foco em estudos de caso leva a uma visão fragmentada da ação coletiva, pois carecem de uma visão mais abrangente do campo multiorganizacional no qual recaem os casos (Taylor, 2002). Além disso, podem levar a uma análise excessivamente otimista sobre a sustentabilidade e os impactos do transnacionalismo". 
temas específicos (VON BÜLOW, 2014, p. 47). A dinamicidade de uma estrutura "leve" não-engessada, barata, que possa ser rediscutida a qualquer momento - seria a forma mais viável de formação de alianças na transnacionalidade.

Ainda sobre o tema das alianças, há um debate, que para a presente pesquisa possui relevância, qual seja o da horizontalidade ou verticalidade característica das formas de aliança das organizações da sociedade civil. Como o objeto de estudo é constituído por um grupo heterogêneo de organizações, que atuam em diferentes planos - local, nacional, global - explorar a relação de poder existente entre elas é de grande interesse. Nesse sentido, Von Büllow (2014, p. 47-48) aponta que "rede" é utilizada predominantemente para descrever formas com menor hierarquia, em que as características de horizontalidade, flexibilidade e democracia interna são enfatizadas ${ }^{61}$.

O Sistema Interamericano de Direitos Humanos apresenta-se como um espaço propício para a construção de redes de organizações. Por sua própria estrutura, que se analisará detidamente no capítulo segundo, as organizações da sociedade civil que possuem como objeto de trabalho os caminhos da litigância internacional têm, por consequência lógica, esse tipo de expertise, que falta às organizações locais. Já a sociedade civil organizada no plano local, da mesma forma, possui um conhecimento técnico específico, que as organizações internacionais não possuem. São as locais, trazendo como exemplo o caso estudado, que conseguem realizar as visitas à unidade prisional, coletar informações in loco, receber denúncias dos presos e de seus familiares, além de pressionar, no dia a dia, os agentes estatais no sentido do cumprimento de suas obrigações. Aponta-se, portanto, $a$ priori, para um equilíbrio entre as atividades e funções que as organizações de uma aliança desempenham.

Contudo, essa realidade específica poderá ser melhor analisada no capítulo terceiro, quando do momento de avaliação das respostas das organizações sobre o tema. $\mathrm{O}$

61 Von Bülow (2014, p. 47-48), ao tratar sobre as alianças entre as organizações da sociedade civil, prescreve que "Com frequência, os autores recorrem ao termo 'redes' para descrever essa tendência a formas menos hierarquizadas e mais flexíveis de ação coletiva. Esse uso do termo fundamenta-se na diferença que os sociólogos organizacionais estabelecem entre formas de organização em rede e as estruturas de governança de mercado ou baseadas na hierarquia (Powell, 1990). Nessa concepção, as redes distinguem-se das hierarquias centralizadas porque são mais horizontais, não possuem cadeia de comando ou controle e, portanto, são muito mais flexíveis e adaptáveis do que as formas organizacionais hierarquizadas. Esse entendimento assemelha-se ao modo como os ativistas empregam o termo, chamando muitas coalizões de 'redes' como um meio de enfatizar sua horizontalidade, flexibilidade de democracia interna. Para esses autores e ativistas, as formas de organização em rede representam 'uma morfologia social superior para toda ação humana' (Castells, 2000, p.15) e estão 'se tornando uma marca distintiva da organização em escala global' (Anheier e Themudo, 2002, p. 191)" (grifo meu). 
que deve ser frisado nesse ponto é que, na transnacionalidade, o elemento internacional pesa na relação de poder que se estabelece entre as organizações. É o mesmo que dizer que há uma tendência de hierarquia nas relações de poder estabelecida entre organizações da sociedade civil numa ação coletiva transnacional, pesando para o lado da organização que possui expertise internacional.

Acerca disso, Von Büllow (2014) afirma que, para se avaliar se um grupo de organizações forma ou não uma rede social, as características devem ser avaliadas empiricamente, ponderando-se sobre a flexibilidade, a hierarquia e a horizontalidade existente entre elas. Segundo a autora,

(...) esse tratamento metafórico do conceito de 'redes' estabelece a priori uma forma superior de organização e, por conseguinte, desvia nossa atenção das relações de poder, assimetrias e conflitos entre atores. Daqui em diante, quando usarmos as expressões 'redes sociais' e 'análise de redes sociais', estaremos referindo-nos à tradição de estudo sobre interações que vem se desenvolvendo no âmbito das Ciências Sociais ao longo dos últimos cinquenta anos. De acordo com essa tradição, determinar se as redes transnacionais são formadas por relações horizontais ou hierárquicas entre os atores é uma questão empírica, assim como estabelecer se essas relações levam a arranjos de governança flexíveis ou não. Ferramentas de análise de redes sociais, combinadas com informações qualitativas, ajudam a determinar se os atores foram exitosos em seus esforços de construção de alianças horizontais" (grifo meu) (VON BÜLOW, 2014, p. 48).

No mesmo sentido que traz a autora, far-se-á, aqui, uma reflexão, com base em dados apontados pelas entrevistas realizadas, sobre as organizações da sociedade civil que estão à frente da demanda do caso Aníbal Bruno, a fim de revelar que tipo de relação de poder foi ali estabelecida.

Ainda com o foco na transnacionalidade e na ação coletiva, Von Büllow (2014, p. 50) aponta como falsa a problemática tendência de organizações locais transformarem-se em globais. Isso porque, segundo a autora, como apontam Anheier e Themudo, “embora o número de ONGs internacionais tenha crescido com regularidade entre 1981 e 2001, as formas organizacionais mais numerosas foram encontradas na categoria de "organizações nacionais com orientação internacional". Tal reflexão consiste em importante subsídio para o presente diálogo, já que há diferenças enormes entre organizações globais e organizações nacionais com orientação internacional, as quais afetam, sobremaneira, as conclusões dessa pesquisa.

Não se fará, nesse momento, a análise dos perfis das organizações que estão 
sendo estudadas na presente investigação; tal tarefa ficará para o capítulo terceiro. Contudo, nota-se que uma organização global de direitos humanos possui o condão de trabalhar com os mais variados países, de forma ilimitada. A organização nacional com orientação internacional possui natureza diversa: funciona dentro de um determinado limite territorial e político - a Nação - todavia, trabalhando com um viés internacional, ou seja, utilizando-se dos instrumentos internacionais, internalizados pelo Estado em que atua - para fazer valer os direitos humanos em disputa.

\subsection{3. Órgãos supranacionais de proteção dos direitos humanos e oportunidade política}

A partir dos anos noventa, observa-se a consolidação da tendência de globalização das instituições jurídicas, com o fortalecimento de tribunais internacionais e a reforma dos tribunais em diversos países, principalmente relacionados a direitos humanos. Em paralelo, o fenômeno da litigância transnacional, consubstanciado na mobilização do direito internacional dos direitos humanos por indivíduos, empresas, organizações da sociedade civil, mostra-se cada vez mais pujante (MACDOWELL SANTOS, 2012, p. 13). No Brasil, esse movimento de internacionalização dos direitos humanos e, mais tarde, de transnacionalização, fez-se sentir de maneira pronunciada, já que a política de direitos humanos brasileira confunde-se com a nossa política externa de direitos humanos ${ }^{62}$.

Do ponto de vista da advocacia em direitos humanos no Brasil, não há como se imaginá-la sem a sua contextualização no e em acordo com o plano internacional, a partir dos debates e movimentos da sociedade civil global e da normativa e instituições internacional de direitos humanos que floresceram nas últimas décadas (VIEIRA \& ALMEIDA, 2011, p. 194).

Com o fim do regime militar em 1985, a eleição indireta do primeiro presidente

62 Esse fato é extremamente relevante para se compreender uma série de fenômenos que, após, serão esmiuçados. O que deve ficar claro, nesse primeiro momento, é a relação umbilical entre a política de direitos humanos no Brasil e a política externa de direitos humanos brasileira. Aqui está uma das explicações do porquê há a discrepância de entendimento sobre o direito internacional dos direitos humanos entre os poderes do Estado brasileiro. Por que há uma vanguarda do Poder executivo? A explicação pode estar no protagonismo do Ministério das Relações Exteriores. "E é muito mais difícil construir uma nação hoje do que foi para os europeus, por exemplo. Quando eles construíram suas grandes nações, o movimento de internacionalização do capitalismo ainda favorecia políticas nacionais ativas" (ARAÚJO, 2012, p. 18-19). Aplicando-se essa mesma lógica, pode-se afirmar que a política de direitos humanos das grandes nações europeias sofre menor influência do direito internacional dos direitos humanos, ou melhor, suas nações já estão melhor formadas a partir dos parâmetros de direitos humanos, o que faz com que a influência do direito internacional dos direitos humanos não se faça sentir na mesma intensidade que nos países periféricos, assim como é o caso dos países latinoamericanos. 
civil e a organização da sociedade civil em torno da constituinte, o governo brasileiro passou a assinar os principais tratados de direitos humanos pendentes na agenda da política externa brasileira, tanto no âmbito das Nações Unidas, quanto da Organização dos Estados Americanos (RAMOS, 2013, p. 214).

Ratificada a Convenção Americana de Direitos Humanos, em 1992, e aceita a jurisdição da Corte Interamericana de Direitos Humanos, em 1995, uma série de organizações, tanto no âmbito interno, quanto internacional, passaram a utilizar os meios de proteção ali contidos como forma de superação da inércia do sistema de justiça brasileiro, quanto ao enfrentamento de violações sistemáticas de direitos humanos (MACDOWELL SANTOS, 2007).

A década das conferências das Nações Unidas, nos anos noventa, impulsionou uma nova corrente de ideias que influenciaram movimentos sociais e a prática das organizações de direitos humanos no Brasil (VIEIRA \& ALMEIDA, 2011, p. 195). A Conferência sobre Meio Ambiente de 1992, a Conferência sobre Direitos Humanos de 1993, a Conferência sobre Desenvolvimento Social de 1995, a Conferência sobre Mulheres de 1995, a Conferência sobre Assentamentos Humanos de 1996 e a Conferência sobre Racismo de 2001 fomentaram, de diversas formas, assim como aos mais diversos atores, a troca de informações e o fluxo de ideias no âmbito de direitos humanos. Foram influenciados, nesse processo, movimentos sociais, organizações sociais e agentes estatais de todo o mundo. Acerca disso, explicam os autores:

Essas conferências internacionais, diferentemente daquelas realizadas anteriormente, mobilizaram milhares de grupos da sociedade civil e defensores de direitos humanos de todo o mundo, não apenas com o intuito de participar das reuniões, mas também de articular propostas da sociedade civil, bem como demandar que os Estados se posicionem sobre esses assuntos. Durante as reuniões preparatórias para as conferências, organizações e defensores de direitos humanos com atuação no âmbito nacional em seus respectivos países começaram a interagir com organizações e defensores de outros países e regiões, o que abriu novas frentes de diálogo no âmbito internacional, bem como permitiu que se vislumbrassem novas formas de engajamento na política internacional; formas essas que não fossem monopolizadas pelos Estados, e tampouco fossem controladas, no âmbito da sociedade civil, por grandes organizações transnacionais do hemisfério Norte" (VIEIRA \& ALMEIDA, 2011, p. 195-196).

A partir desses eventos, houve uma exposição dos movimentos sociais e 
organizações brasileiras a esse processo de internacionalização dos direitos humanos (VIEIRA \& ALMEIDA, 2011, p. 196), que contribuiu, sobremaneira, para que o cenário da sociedade civil que trabalha com direitos humanos no Brasil seja o que é hoje.

Estabelecida essa circunstância especial do significado do direito internacional dos direitos humanos no Brasil, Hunt (2009) esclarece que a estrutura internacional dos direitos humanos, com suas normativas e instituições, "talvez seja exasperadora na sua lentidão para reagir ou na sua repetida incapacidade de atingir seus objetivos principais" (HUNT, 2009, p. 215-216). Contudo, a autora é enfática ao colocar que, atualmente, não há outra estrutura mais adequada para o confronto dessas questões ${ }^{63}$.

Na mobilização de "multidões de indivíduos", como coloca essa autora, essa estrutura é fundamental para a pressão que precisa existir no sentido da significação e da construção dos direitos humanos. Direitos humanos é uma pauta contra-hegemônica. Daí, a necessidade que sempre se atualiza de que muitas pessoas estejam envolvidas no processo, a fim de exercer seu potencial político.

Colocado de forma simplificada, esses órgãos supranacionais de proteção dos direitos humanos apresentam-se como a concretização de um espaço em que mais camadas de proteção estão disponíveis para os cidadãos. Não é uma questão de se utilizar uma (o ordenamento jurídico internacional) em detrimento da outra (o ordenamento jurídico nacional): as várias camadas de proteção sobrepõem-se umas às outras, fazendo com que o cidadão possa se utilizar, quando assim escolher/necessitar, de uma, ou outra, ou, ainda, ambas.

Nesse quadro, importa aqui explorar o conceito de "oportunidade política" nos termos de Tarrow (2009). Antes, porém, por conta da abordagem do autor, deve-se atentar para o debate em torno do "confronto político". Isto porque, em sua argumentação relativa à oportunidade política, confronto político é um conceito central para esse autor, tanto que postula a seguinte questão: "por que o confronto político parece desenvolver-se apenas em períodos particulares da história e por que às vezes ele produz movimentos sociais robustos e às vezes se transforma em sectarismo ou repressão?”"64 (TARROW, 2009, p. 38).

63 Acerca disso, a Hunt (2009, p. 215-216) pontua o seguinte: “A estrutura dos direitos humanos, com seus órgãos internacionais, cortes internacionais e convenções internacionais, talvez seja exasperadora na sua lentidão para reagir ou na sua repetida incapacidade de atingir seus objetivos principais, mas não existe nenhuma estrutura mais adequada para confrontar essas questões. As cortes e organizações governamentais , por mais que tenham alcance internacional, serão sempre freadas por considerações geopolíticas. A história dos direitos humanos mostra que os direitos são afinal mais bem defendidos pelos sentimentos, convicções e ações de multidões de indivíduos, que exigem respostas correspondentes ao seu senso íntimo de afronta."

64 Para a melhor compreensão do contexto, reproduzo o parágrafo integralmente (TARROW, 2009, p. 38): 
Para o autor, movimentos sociais e confronto político estão intrinsecamente conectados; poder-se-ia dizer, inclusive, que para ele o confronto político é uma categoria essencial do conceito "movimentos sociais", enquanto outros autores fazem outras escolhas. Importante para a presente pesquisa é que o conceito de oportunidade política também está ligado ao de confronto político.

Isso, a princípio, impôs algumas dificuldades porque temos uma cabeça formatada para compreender o confronto numa acepção muito limitada. Não consegui, a princípio, por exemplo, imaginar confronto dentro de um ambiente institucionalizado, como são a Comissão ou a Corte Interamericana de Direitos Humanos. Contudo, essa é uma barreira cultural, e não necessariamente uma proposição verdadeira. Política é confronto; no âmbito do confronto, utiliza-se o direito como instrumento.

A partir da ideia de confronto ${ }^{65}$, chega-se à sua compreensão de oportunidade política, que significa “dimensões consistentes - mas não necessariamente formais, permanentes ou racionais - da luta política que encorajam as pessoas a se engajar no confronto político" (TARROW, 2009, p. 38). Ademais, o conceito de oportunidade política enfatiza recursos que são externos à organização, ou seja, não são capacidades, habilidades ou possibilidades do grupo ou dos integrantes do grupo, mas, sim, fatores externos, dos quais se pode tirar vantagem a fim de criar ou otimizar uma ação coletiva.

Não importa, aqui, examinar-se o surgimento dos confrontos políticos ${ }^{66}$; contudo,

\footnotetext{
"No entanto, a abordagem processo político/oportunidades propôs uma resposta à questão que inquietou as abordagens anteriores: por que o confronto político parece desenvolver-se apenas em períodos particulares da história e por que às vezes ele produz movimentos sociais robustos e às vezes se transforma em sectarismo ou repressão? Além disso, por que os movimentos assumem formas diferentes em ambientes políticos diversos? Como essa abordagem não pretende explicar cada aspecto do confronto político ou dos movimentos sociais, ela pode tornar-se parte de uma síntese como eu proponho aqui, incluindo percepções de outros ramos da teoria do movimento social".

65 Tarrow (2009, p. 38) sintetiza o que se segue: “O argumento mais forte deste estudo será o de que as pessoas se engajam em confrontos políticos quando mudam os padrões de oportunidades e restrições políticas e, então, empregando estrategicamente um repertório de ação coletiva, criam novas oportunidades que são usadas por outros, em ciclos mais amplos de confronto. Quando suas lutas giram em torno de grandes divisões na sociedade, quando reúnem pessoas em volta de símbolos culturais herdados e quando podem ampliar ou construir densas redes sociais e estruturas conectivas, então esses episódios de confronto resultam em interações sustentadas com opositores - especificamente, em movimentos sociais".

66 Tarrow (2009, p. 39) trabalha com a ideia de estrutura de oportunidades políticas, não propondo propriamente um modelo, mas sim uma forma de analisar alguns indícios que podem ajudar a antever o surgimento de confrontos políticos: "Não há uma forma simples para prever o surgimento do confronto, não só porque a especificação dessas variáveis muda em diferentes circunstâncias históricas e políticas como fatores diferentes podem variar em direções opostas. Como resultado, o termo 'estrutura de oportunidades políticas' não deveria ser entendido como um modelo invariável que produz, inevitavelmente, movimentos sociais, mas como um conjunto de indícios de quando surgirá um confronto político, colocando em movimento uma cadeia causal que pode levar a uma interação sustentada com autoridades e, portanto, a movimentos sociais." O interesse, para a presente pesquisa, reside em trabalhar com a ideia de oportunidade política - e seu contraponto que é a restrição - para compreender as razões que levam a sociedade civil brasileira a buscarem
} 
ao lado de oportunidades políticas, há as restrições políticas, que o autor determina, de forma simples, como aqueles fatores que desencorajam o confronto (TARROW, 2009, p. 3839).

Nesse sentido, pode-se afirmar que os órgãos supranacionais de proteção dos direitos humanos são espaços repletos de oportunidades políticas para a sociedade civil brasileira. Tanto no sistema universal ou global de proteção dos direitos humanos - Sistema da Organização das Nações Unidas ${ }^{67}$-, quanto nos sistemas regionais de proteção dos direitos humanos - Sistema Europeu, Africano e Americano ${ }^{68}$, há uma série de oportunidades - e também restrições - políticas, ao dispor da sociedade civil para a sua luta diuturna em defesa e pela promoção dos direitos humanos.

Examinar-se-á mais detidamente quais são essas oportunidades políticas para a sociedade civil brasileira no âmbito do Sistema Interamericano de Direitos Humanos, mais especificamente em relação a violações coletivas relativas às pessoas privadas de liberdade, tema do caso em concreto que se está a estudar.

\subsection{O elemento "direito"}

Conclui-se, até o presente momento, que as redes de organizações da sociedade civil, e suas ações coletivas no sentido da luta pelos direitos humanos utilizam, como instrumento, a mobilização transnacional, a partir do conceito de MacDowell Santos, essa e mobilização refere-se especificamente ao direito.

Mas, afinal, qual direito está sendo, aqui, reivindicado?

Há muitas teorias jurídicas sobre o direito, além de todas as discussões sobre o que significa do ponto de vista sociológico, histórico, político, filosófico, econômico. O

respostas às violações de direitos humanos no Sistema Interamericano de Direitos Humanos. Para tanto, não interessa antever o confronto político, mas esmiuçar o sentido mesmo de oportunidade política.

67 RAMOS $(2013$, p. 77) apresenta as possibilidades que existem em termos de direitos humanos no âmbito das Nações Unidas, a partir da perspectiva jurídica: "O sistema convencional possui três grandes divisões: a não contenciosa, que é a mais antiga e elaborada a partir de técnicas de solução de controvérsias do Direito Internacional clássico, tais como os bons ofícios e a conciliação. Há ainda o sistema quase judicial, que possui duas espécies: a responsabilização iniciada por petições de Estados e ainda por petições de particulares contra Estados. Finalmente, há o sistema judicial ou contencioso, no qual a responsabilidade internacional do Estado por violação de direitos humanos é estabelecida através de um processo judicial, processado perante a Corte Internacional de Justiça. O sistema extra convencional é composto de procedimentos especiais no âmbito de órgãos da Organização das Nações Unidas, embasados no dever geral de cooperação internacional dos Estados em matéria de direitos humanos, reconhecido na Carta da Organização das Nações Unidas."

68 No próximo capítulo, foca-se na análise do Sistema Interamericano de Direitos Humanos. Haverá espaço, daí, para uma breve explanação sobre os sistemas regionais de proteção dos direitos humanos. 
importante, para a presente pesquisa, é fixar que, em nossa sociedade contemporânea, é por meio do direito - mas não somente por meio dele, mas, precipuamente, mesmo que em parte por meio dele - que se dá a luta pelos direitos humanos. Pode-se afirmar, portanto, que ele é um instrumento sine qua non da luta pelos direitos humanos.

Entretanto, para que o direito cumpra esse papel, deve possuir características tendentes à transformação social, e não se constituir em um mero instrumento de manutenção do status quo. Quando se referir a "direito" nessa dissertação, será nesse sentido: o direito contextualizado dentro do mundo dos direitos humanos, um instrumento da concretização dos direitos humanos, e jamais um fim em si mesmo.

A dinamicidade, a dialética, o movimento e a transformação são ideias que permeiam o direito; este não é nada, mas é tudo sendo (LYRA FILHO, 1982, p. 6). O direito mantém-se em movimento constante, no sentido da transformação social contínua ${ }^{69}$. Daí não fazer sentido a análise do direito descontextualizado das lutas sociais que se encontram em sua base. A busca que nos levará a respostas mais sólidas e confiáveis, portanto, não é “o que é o Direito", mas, sim, “o que vem sendo e o que poderá vir a ser o Direito"70.

A compreensão de direitos humanos deve ser, portanto, expandida por meio do direito, dentro da ideia de um processo, e jamais somente como um conjunto de normas internacionais que, por mais que advoguem pela proteção dos seres humanos, com vistas à manutenção e promoção de sua dignidade intrínseca, o fazem dentro de uma perspectiva estática e estadocêntrica, que não dá conta das necessidades que há na realidade da vida das pessoas. Premente que os direitos humanos tenham uma construção, por meio do direito, ao

69 Lyra Filho (1982) esclarece sua ideia de direito, afirmando que: "Nosso objetivo é perguntar, no sentido mais amplo, o que é Direito (com ou sem leis), mas é preciso esclarecer, igualmente, que nada é, num sentido perfeito e acabado; que tudo é, sendo. Queremos dizer, com isto, que as coisas não obedecem a essências ideais, criadas por certos filósofos, como espécie de modelo fixo, um cabide metafísico, em que penduram a realidade dos fenômenos naturais e sociais. As coisas, ao contrário, formam-se nestas próprias condições de existência que prevalecem na Natureza e na Sociedade, onde ademais se mantêm num movimento constante e contínua transformação. E deste modo que elas se entrosam na totalidade dos objetos observáveis e das forças naturais e sociais, que os modelam e orientam a sua evolução. Cada fenômeno (fenômeno é, etimologicamente, coisa que surge) pode, então, revelar o seu fundamento e sentido, que só emerge em função daquela totalidade móvel. Isoladamente, cada um perde a significação própria e a conexão vital, assim como o órgão sem o organismo em que funciona, ou o homem, sem a sociedade, fora da qual ele não existe humanamente e regride na escala zoológica" (grifo meu) (LYRA FILHO, 1982, p. 6).

70 Lyra Filho (1982) continua sua análise sobre o Direito: "Nesta perspectiva, quando buscamos o que o Direito é, estamos antes perguntando o que ele vem a ser, nas transformações incessantes do seu conteúdo e forma de manifestação concreta dentro do mundo histórico e social. Isto não significa, porém, que é impossível determinar a "essência" do Direito - o que, apesar de tudo, ele é, enquanto vai sendo: o que surge de constante, na diversidade, e que se denomina, tecnicamente, ontologia. Apenas fica ressalvado que uma ontologia dialética, tal como indicava o filósofo húngaro, Lukács, tem base nos fenômenos e é a partir deles que procura deduzir o "ser" de alguma coisa, buscado, assim, no interior da própria cadeia de transformações" (grifo meu) (ibid). 
mesmo tempo prática e teórica, apresentando "alternativas reais no mundo que nos tocou viver"

\subsubsection{Há potencial emancipatório no direito?}

A partir dessa proposição, de que os direitos humanos são uma plataforma de construção de novas alternativas para a vida em sociedade, questiona-se, com gravidade, se o direito - tal como ele se encontra na sociedade política atual - dá conta de ser esse veículo. Aqui, pontua-se o debate sobre duas categorias que podem auxiliar no esclarecimento desse tema, que são regulação e emancipação.

Com o advento do Estado liberal, o direito foi reduzido ao direito estatal, assim como a tensão entre a regulação e a emancipação social passou a ter carga preponderantemente regulatória ${ }^{72}$. O que há de emancipatório na institucionalidade passou a ser, necessariamente, autorizado - ou não - pelo direito, agora integralmente estatal.

Santos (2003) trabalha com a ideia de que há um espaço, na sociedade, tanto para a regulação, quanto para a emancipação, e que essa tensão dialética que se estabelece entre ambas é ainda chave para a transformação social ${ }^{73}$. Portanto, a questão a ser perseguida não reside na superação da emancipação pela regulação, ou mesmo no contrário, mas, sim,

71 Vale a pena aqui destacar a seguinte passagem de Herrera Flores (2009, p. 11-12): "Para isso, devemos ampliar nossas formas de compreensão dos direitos humanos e considerá-los como processos - normativos, sociais, políticos, econômicos - que abram ou consolidem espaços de luta pela dignidade humana, em outros termos, conjuntos de práticas que potenciem a criação de dispositivos e de mecanismos que permitam a todas e a todos poder fazer suas próprias histórias. Reivindiquemos, portanto, uma imaginação, uma teoria e uma prática que rompam os cercos nos quais nos encerram os deficits e os excessos de sentido e construamos a possibilidade de apresentar alternativas reais no mundo que nos tocou viver. Dizer não, víamos mais acima, é dizer sim a algo diferente. Comecemos por definir os direitos humanos pelo que são: produtos culturais que facilitem a construção das atitudes e aptidões que nos permitam poder fazer nossas vidas com o máximo de dignidade."

72 Santos (2003) começa, assim, o questionamento sobre a possibilidade de o direito ser emancipatório: “Assim que o Estado liberal assumiu o monopólio da criação e da adjudicação do direito - e este ficou, assim, reduzido ao direito estatal - a tensão entre a regulação social e a emancipação social passou a ser um objecto mais da regulação jurídica. Nos termos da distinção entre emancipação social legal e ilegal - desde, então, uma categoria política e jurídica essencial -, só seriam permitidos os objectivos e práticas emancipatórios sancionados pelo Estado e, por conseguinte, conformes aos interesses dos grupos sociais que lhes estivessem, por assim dizer, por trás" (SANTOS, 2003, p. 4).

73 A tensão entre a regulação e a emancipação é, ainda, uma proposta válida para a transformação social, como adverte SANTOS (2003, p. 7): “O abandono completo da tensão entre a regulação social e a emancipação social, ou da própria ideia de transformação social - que é a proposta dos que tenho designado por pósmodernistas celebratórios -, parece ser, por conseguinte, uma proposta politicamente arriscada, não só porque coincide com a agenda conservadora, mas também porque não se perfilam no horizonte concepções novas com potencial para captar as aspirações políticas condensadas nos conceitos modernos. Reinventar a tensão entre regulação social e emancipação social afigura-se, por isso, uma proposta melhor, ou mais prudente, do que atirá-la simplesmente para o caixote do lixo da história" (grifo meu). 
no reconhecimento dessa tensão e no que poderá ser produzido nesse âmbito.

A partir desse questionamento, o autor propõe a tão relevante pergunta: "como reinventar o direito para lá do modelo liberal e demo-socialista e sem cair na agenda conservadora - e, mais ainda, como fazê-lo de modo a combater esta última de uma maneira mais eficaz?" (SANTOS, 2003, p. 8).

Uma das diversas formas apontadas para realizar esse enfrentamento é a ação coletiva transnacional. O confronto da ideia de globalização neoliberal ocorre por meio de grupos, redes, iniciativas, organizações e movimentos, dos e nos âmbitos local, nacional e transnacional, com a finalidade da busca por alternativas de globalização contrahegemônica ${ }^{74}$.

Nesse sentido, Santos (2003) propõe que o direito, enquanto instrumento hegemônico pode ser utilizado não somente de uma maneira hegemônica (2003, p. 36). Com base nesse modelo, uma organização da sociedade civil pode, por exemplo, ingressar no Poder Judiciário com uma demanda judicial, a fim de receber prestação jurisdicional estatal. Contudo, a maneira como articulará tal demanda - grupo de pessoas envolvidas se reunirão para debater a demanda, advogadas e advogados populares e membros da organização debaterão a demanda, discutirão outras possibilidades que não o ingresso no Poder Judiciário, irão ponderar o fenômeno da judicialização da vida política, todas e todos vão se apropriar dos instrumentos normativos e órgãos estatais envolvidos, assim como, depois do ingresso da demanda, esse ciclo se repete, num processo de aprendizagem e crítica constante - é que será contra-hegemônica.

Em suma, não se afirma que o direito estatal deva ser excluído da prática política $^{75}$; “eles (os direitos) podem ser usados, ainda que integrados em lutas mais vastas,

74 Sobre a globalização contra-hegemônica, Santos (2003, p. 27) pontua: “Apesar de ser a forma hegemônica de globalização, a globalização neoliberal não é a única que há. Por todo o mundo se assiste a grupos sociais, redes, iniciativas, organizações e movimentos de tipo local, nacional e transnacional, que se têm mostrado activos no esforço de enfrentar a globalização neoliberal e de lhe contrapor alternativas. Pondo de parte combates que originariamente já são de âmbito transnacional, incluo neste vasto conjunto de políticas de tipo confrontacional lutas sociais que, não obstante terem uma incidência local ou nacional, revelam estar conectados de diferentes modos com lutas paralelas travadas noutros lugares. Em conjunto, elas constituem aquilo que chamo de globalização contra-hegemônica".

75 Santos (2003) analisa o uso contra-hegemônico do direito da seguinte forma: "Uma coisa é utilizar um instrumento hegemônico num dado combate político. Outra coisa é utilizá-lo de uma maneira hegemônica. Isto aplica-se tanto aos direitos como à política dos direitos. De acordo com o cosmopolitismo subalterno, e como demonstrarei mais adiante, nem o direito se resume ao direito estatal, nem os direitos se resumem aos direitos individuais. Isso não significa, contudo, que o direito estatal e os direitos individuais devam ser excluídos das práticas jurídicas cosmopolitas. Pelo contrário, eles podem ser usados, ainda que integrados em lutas mais vastas, que os retirem dos moldes hegemônicos. Esse molde, em essência, é a ideia de autonomia e a ideia de que os direitos são, ao mesmo tempo, meios e fins da prática social” (SANTOS, 2003, p. 36). 
que os retirem dos moldes hegemônicos". Ao contrário, pode-se afirmar, portanto, que o direito, em seu quadro contra-hegemônico, constitui-se em um meio na luta pelos direitos humanos.

Tal possibilidade, a do uso contra-hegemônico do direito e dos direitos, poderá ocorrer caso haja uma integração deles com "mobilizações políticas de âmbito mais vasto, que permitam que as lutas sejam politizadas antes de serem legalizadas" (SANTOS, 2003, p. 37). Não basta, de igual sorte, que se faça a luta até a legalização de um determinado direito; a mobilização deve ser contínua, não apenas em torno da criação de direitos, mas, também, da sua concretização e constante debate e crítica de sua aplicação ${ }^{76}$. As necessidades humanas estão em constante mudança; a aplicação do direito deve acompanhá-las, o que somente poderá ocorrer se a sociedade civil se mantiver permanentemente mobilizada ao redor dessa agenda.

Ao final do artigo, Santos (2003) chega a uma conclusão lacônica: "no fim e ao cabo, o direito não pode ser nem emancipatório, nem não emancipatório, porque emancipatórios e não-emancipatórios são os movimentos, as organizações e os grupos cosmopolitas subalternos que recorrem à lei para levar as suas lutas por diante" (SANTOS, 2003, p. 71). Lacônica porque é uma resposta de fora do direito, quando a proposta inicial era, justamente, o debate sobre se seria possível, ou não, o direito ser emancipatório.

Aqui, discorda-se do autor, portanto, usando os seus próprios argumentos e lógica: para propor que o direito e os direitos podem, sim, ser emancipatórios, devem ser vistos como instrumentos da emancipação - e não confundidos com a emancipação em si mesma - e, por óbvio, acompanhados da mobilização social e política que tão bem referiu o autor. A partir dessa perspectiva, de um direito e de direitos permanentemente em tensão dialética entre regulação e emancipação, podendo, portanto, ser veículos da emancipação, parte-se para o debate sobre o acesso à justiça.

\subsubsection{O acesso à justiça está para além do Poder Judiciário}

76 Nesse sentido, explica Santos, destacando a integração do direito e dos direitos com a mobilização política, como se segue: "Existe, no entanto, a possibilidade de o direito e os direitos serem usados como nãoautónomos e não-exclusivos. Tal possibilidade assenta no pressuposto da 'integração' do direito e dos direitos em mobilizações políticas de âmbito mais vasto, que permitam que as lutas sejam politizadas antes de serem legalizadas. Havendo recurso ao direito e aos direitos, há também que intensificar a mobilização política, por forma a impedir a despolitização da luta - despolitização que o direito e os direitos, se abandonados a si próprios, serão propensos a causar. Uma política de direito e direitos forte é aquela que não fica dependente apenas do direito ou dos direitos" (grifo meu) (SANTOS, 2003, p. 37). 
Estabelecido que o direito e os direitos podem ser, sim emancipatórios, discutese, agora, de que forma isso se encontra institucionalizado. Mais uma vez, traz-se à baila uma visão predominantemente conservadora do direito - e da esmagadora maioria de seus teóricos e aplicadores - consubstanciada na ideia de prestação jurisdicional. Jurisdição é, em sua origem, simplesmente "dizer o direito". Esse papel, que antes era ligado a uma ideia mística/religiosa, é, desde o advento da república, dos juízes. Grosso modo, nos últimos séculos, houve uma identificação total entre a ideia de justiça e o personagem social juiz.

Nas últimas décadas, no Brasil, o Poder Judiciário ganhou enorme força política, estrutura e orçamento, especialmente depois da Constituição Federal de 1988. Nesse sentido, reforçou-se, ainda mais, a ideia de que a prestação jurisdicional, ou seja, o "dar" o direito para o usuário do Poder Judiciário, tem identidade integral com o fenômeno justiça. Há uma série de equívocos nesse raciocínio e, por óbvio, em seus desdobramentos; contudo, não será possível abordá-los em suas especificidades. Dois deles, entretanto, são importantes para o estudo do presente objeto de pesquisa.

O primeiro que se destaca é que o Poder Judiciário não subsumi todas as funções da prestação jurisdicional estatal. No caso brasileiro, tem-se utilizado, de forma acertada, a expressão "Sistema de Justiça" a fim de melhor compreender que são várias as instituições, para além do Poder Judiciário, que possuem atribuições relativas à prestação jurisdicional estatal. Ministério Público, Defensoria Pública, Advocacia Pública, Polícias Civil e Militar, Secretarias de Justiça e Segurança Pública dos Estados são órgãos que trabalham em conjunto no sentido de garantir a totalidade da prestação jurisdicional para o usuário do Sistema de Justiça.

Colocado de outra forma, a prestação jurisdicional não deveria ser assim denominada, já que o Sistema de Justiça como um todo tem de funcionar para que seu usuário receba, ao final, sua parcela de justiça. A melhor denominação seria, portanto, prestação de justiça ou prestação judicial estatal. A relevância desse debate para a presente investigação restará evidente quando do debate sobre as deficiências do Estado brasileiro em produzir, em termos de justiça, respostas à violação do caso em concreto. O debate sobre a federação e a repartição dos poderes, assim como os papeis dos diversos órgãos do Sistema de Justiça, colocará uma luz sobre as responsabilidades que devem ser compartilhadas, dentro do Estado brasileiro, para que se cumpram as determinações da Comissão e da Corte Interamericana de Direitos Humanos relativamente às violações da referida unidade 
prisional.

A outra questão que deve ser necessariamente abordada é que, mesmo sob o crivo crítico e, assim, utilizando a terminologia "Sistema de Justiça" e "prestação judicial estatal", é que, nem sempre, o modelo clássico adversarial é o mais indicado para se buscar a paz social. O modelo adversarial é, basicamente, aquele em que uma pessoa, ao se esbarrar com uma pretensão resistida por outra, vai a um terceiro - que no modelo adversarial é o Estado - e pede a este que lhe dê o que a outra parte, autora da ação ou omissão que produz a pretensão resistida, objeto da resistência, com base no direito positivo.

Dessa forma, não há como se chegar a consensos, acertos, negociações. A burocratização, excesso de regras e formalismo exacerbado produzem um espaço de distanciamento entre os sujeitos, e ainda distanciamento maior daquele terceiro que julgará a ação. O sistema adversarial tem sido combatido no mundo todo, justamente porque se comprovou resultar em custos altíssimos, demora na resposta para o usuário e respostas que não agregam no sentido da construção da paz social.

$\mathrm{O}$ acesso à justiça ${ }^{77}$, portanto, deve ser visto de forma mais abrangente, na busca pela igualdade efetiva entre as pessoas, e não apenas na acepção formal do acesso à justiça (CAPPELLETTI \& GARTH, 1988, p. 9). Nessa transição entre uma visão formalista para uma substantiva ou concretizadora do acesso à justiça, os direitos sociais, sua normatização e aplicação, podem ser creditados como impulsionadores dessa mudança ${ }^{78}$. Isso porque eles têm características coletivas, e não individuais, como os clássicos direitos da primeira geração.

Em sua obra clássica “Acesso à justiça”, de 1978, Cappelletti \& Garth refletem sobre o acesso à justiça a partir de uma longa pesquisa feita com sede na Itália sobre o tema.

77 A partir daqui, entender-se-á justiça no seguinte sentido: “O reconhecimento dessa necessidade urgente (de centrar a atenção no 'homem comum') reflete uma mudança fundamental no conceito de 'justiça'. No contexto de nossas cortes e procedimentos formais, a 'justiça' tem significado essencialmente a aplicação das regras corretas de direito aos fatos verdadeiros do caso. Essa concepção de justiça era o padrão pelo qual os processos eram avaliados. A nova atitude em relação à justiça reflete o que o Professor Adolf Hamburger chamou de 'uma mudança radical na hierarquia de valores servida pelo processo civil'. A preocupação fundamental é, cada vez mais, com a 'justiça social', isto é, com a busca de procedimentos que sejam conducentes à proteção dos direitos das pessoas comuns" (grifo meu) (CAPPELLETTI \& GARTH, 1988, p. 93).

78 Cappelletti \& Garth (1998) “À medida que as sociedades do laissez-faire cresceram em tamanho e complexidade, o conceito de direitos humanos começou a sofrer uma transformação radical. A partir do momento em que as ações e relacionamentos assumiram, cada vez mais, caráter mais coletivo que individual, as sociedades modernas necessariamente deixaram para trás a visão individualista dos direitos, refletida nas 'declarações de direitos', típicas dos séculos dezoito e dezenove. O movimento fez-se no sentido de reconhecer os direitos e deveres sociais dos governos, comunidades, associações e indivíduos. Esses novos direitos humanos, exemplificados pelo preâmbulo da Constituição Francesa de 1946, são, antes de tudo, os necessários para tornar efetivos, quer dizer, realmente acessíveis a todos, os direitos antes proclamados" (CAPPELLETTI \& GARTH 1988, p. 10-11): 
O livro tornou-se uma referência, principalmente porque sua abordagem era não apenas teórica, mas também de investigação das práticas de justiça de alguns países, o que conferiu profundidade às suas conclusões.

Contudo, já de início, pontua-se duas questões de ordem crítica sobre o texto. Primeiramente, os autores refletem sobre o acesso à justiça, colocando-o como o mais básico dos direitos humanos ${ }^{79}$, no âmbito de um sistema jurídico moderno e igualitário que pretenda concretizar direitos. Ora, num trabalho em que se discute a mobilização da sociedade civil em relação a direitos humanos, não se pode concordar com essa afirmação. Isso porque o acesso à justiça é uma das formas de se garantir os direitos, mas não a única. Se houver a garantia de prestação jurisdicional perfeita, porém, sem a possibilidade de livre expressão e manifestação popular, como se pode falar em democracia?

O que se pretende apontar aqui é que a possibilidade de mobilização, tanto da justiça, mas também da política - e isso implicaria os direitos de livre expressão e manifestação, associação e liberdade política num sentido amplo, não apenas esse da democracia representativa - poderiam ser considerados os direitos humanos mais básicos, nunca apenas o acesso à justiça sozinho.

Contudo, os autores alertam para a função social do processo, assim como que os tribunais não podem ser a única forma de solução de conflitos. Alternativas ao Poder Judiciário são encorajadas como maneira de otimizar o acesso à justiça, levando em conta como se opera a lei, a frequência de sua execução, que benefício provoca e que tipo de impacto social produz (CAPPELLETTI \& GARTH, 1988, p. 12-13).

Afirma-se, a partir das considerações do texto, produzido por juristas altamente renomados e respeitados na área do Processo Civil, que o Poder Judiciário, com seus juízes e cortes, não são, e não podem ser, a única forma de se acessar a justiça.

Há uma série de obstáculos ao acesso à justiça, dentro desse paradigma conservador de que justiça se identifica integralmente com Poder Judiciário. Entre eles, estão as custas judiciais, a demora para a prestação jurisdicional, os recursos financeiros diferença econômica entre as partes que são refletidas para dentro do processo -, capacidade processual. A efetividade do acesso à justiça reside na completa igualdade de armas (CAPPELLETTI \& GARTH, 1988, p. 15). Para isso, esses obstáculos devem ser combatidos

79 Discorda-se veementemente da afirmação proposta pelos autores: "O acesso à justiça pode, portanto, ser encarado como o requisito fundamental - o mais básico dos direitos humanos - de um sistema jurídico moderno e igualitário que pretenda garantir, e não apenas proclamar os direitos de todos" (CAPPELLETTI \& GARTH, 1988, p. 12). 
para serem, ao menos, mitigados.

A fim de exporem da melhor forma suas ideias, os autores trabalharam com a ideia de construção histórica da resposta jurisdicional, sob a forma de 3 ondas do acesso à justiça. Cappelletti \& Garth (1988) explanam, de forma sucinta, as três ondas do acesso à justiça:

O recente despertar de interesse em torno do acesso efetivo à Justiça levou a três posições básicas, pelo menos nos países do mundo Ocidental. Tendo início em 1965, estes posicionamentos emergiram mais ou menos em sequência cronológica. Podemos afirmar que a primeira solução para o acesso - a primeira 'onda' desse movimento novo - foi a assistência judiciária; a segunda dizia respeito às reformas tendentes a proporcionar representação jurídica para os interesses 'difusos', especialmente nas áreas de proteção ambiental e do consumidor; e o terceiro - e mais recente - é o que nos propomos a chamar simplesmente de 'enfoque de acesso à justiça' porque inclui os posicionamentos anteriores, mas vai muito além deles, representando, dessa forma, uma tentativa de atacar as barreiras ao acesso de modo mais articulado e compreensivo" (CAPPELLETTI \& GARTH, 1988) p. 31) (grifo meu).

A primeira onda é completamente identificada com o modelo judicial, por meio da assistência judiciária. Basicamente, seria a garantia de que todos tenham representação judicial - um advogado - para que haja equilíbrio na relação processual estabelecida.

Em relação à segunda onda, os autores trabalham com a possibilidade de um tipo específico de ação governamental - utilizam-se do exemplo do Ministério Público ${ }^{80}$. Contudo, essa possibilidade se dá dentro do enfoque que coloca a centralidade do acesso à justiça no Poder Judiciário. Importante observar que, ao tratar da segunda onda, os autores apenas trazem exemplos de instituições e práticas judiciais ou do Sistema de Justiça, a não ser uma breve menção à “(...) criação de certas agências públicas regulamentadoras altamente especializadas, para garantir certos direitos do público ou outros interesses difusos - são muito importantes, mas, também, limitadas" (CAPPELLETTI \& GARTH, 1988, p. 52). Essa foi a única menção dos autores ao acesso à justiça sem o envolvimento de um órgão do que já se denominou na presente investigação de Sistema de Justiça.

Quanto à terceira onda, incluem-se a advocacia privada e pública, nos âmbitos

80 A respeito do Ministério Público, os autores, já naquela oportunidade, têm importante observação a fazer: “O Ministério Público dos sistemas continentais e as instituições análogas, incluindo o Staatsanwalt alemão e Prokuratura soviética, estão inerentemente vinculados a papeis tradicionais restritos e não são capazes de assumir, por inteiro, a defesa dos interesses difusos recentemente surgidos. Eles são amiúde sujeitos a pressão política - uma grande fraqueza, se considerarmos que os interesses difusos, frequentemente, devem ser afirmados contra entidades governamentais.” (CAPPELLETTI \& GARTH, 1988, p. 51-52). Sobre o Ministério Público, haverá mais oportunidades no presente trabalho para destaque e debate sobre sua relação com as organizações da sociedade civil. 
judicial e extrajudicial. Contudo, vai-se além, trabalhando com a ideia de centrar a atenção no "conjunto geral de instituições e mecanismos, pessoas e procedimentos utilizados para processar e prevenir disputas nas sociedades modernas" (CAPPELLETTI \& GARTH, 1988, p. 67-68).

Resta claro que a representação judicial, por si só, não é suficiente para dar conta do significado social e político que o acesso à justiça possui na atualidade ${ }^{81}$. Assim como mostra-se insustentável que muitas áreas da vida humana, quiçá todas, sejam levadas aos tribunais e debatidas apenas entre advogados, mesmo que essas práticas judiciais sejam aperfeiçoadas. Com o foco na concretização dos direitos, e como os novos direitos exigem novas formas de execução, são necessárias novas respostas em relação ao acesso à justiça.

Nesse sentido, fundamental uma discussão sobre o Poder Judiciário e o Sistema de Justiça (CAPPELLETTI \& GARTH, 1988, p. 69). No livro, os autores, inclusive por conta do tempo que o texto já tem e das muitas inovações que se sucederam - inclusive as tecnológicas -, exploram um número bastante reduzido de alternativas ${ }^{82}$, que buscam fazer frente a essas demandas de renovação das alternativas de prestação jurisdicional ${ }^{83}$.

Importante, contudo, para o presente trabalho, assentar-se que o conceito de acesso à justiça foi expandido pelos autores - mesmo que de forma breve - tanto para além do Poder Judiciário, quanto para além mesmo do Estado. Concorda-se com tal expansão.

A experiência das organizações da sociedade civil no âmbito do Sistema Interamericano de Direitos Humanos, com sua Comissão e Corte, tem mostrado que há formas especializadas - no caso, em direitos humanos - de criação e ressignificação do sentido do acesso à justiça. É nesse debate - entre a teoria clássica do Direito e a experiência interamericana - que se procuram elementos para construir um conceito de acesso à justiça que seja condizente com as necessidades da vida prática das vítimas e organizações que

81 Por uma nova concepção de acesso à justiça, advogam os autores que o se segue: “A representação judicial - tanto de indivíduos, quanto de interesses difusos - não se mostrou suficiente, por si só, para tornar essas mudanças de regras 'vantagens tangíveis' ao nível prático. (...) Não é possível, nem desejável resolver tais problemas com advogados apenas, isto é, com uma representação judicial aperfeiçoada. Entre outras coisas, nós aprendemos, agora, que esses novos direitos frequentemente exigem nos mecanismos procedimentais que os tornem exequíveis" (CAPPELLETTI \& GARTH,1988, p. 68-69).

82 Os autores assim discriminam “(...) esse enfoque encoraja a exploração de uma ampla variedade de reformas, incluindo alterações nas formas de procedimento, mudanças na estrutura dos tribunais ou a criação de novos tribunais, o uso de pessoas leigas ou para profissionais, tanto como juízes quanto como defensores, modificações no direito substantivo destinadas a evitar litígios ou facilitar sua solução e a utilização de mecanismos privados ou informais de solução dos litígios. Esse enfoque, em suma, não receia inovações radicais e compreensivas, que vão muito além da esfera de representação judicial.” (grifo meu) (CAPPELLETTI \& GARTH, 1988, p. 71).

83 Muitas outras alternativas são apontadas por Santos (2011), ao tratar, especificamente, o caso brasileiro. 
defendem e promovem direitos humanos em nosso país.

\subsubsection{O necessário alargamento do direito}

No ponto anterior, afirmou-se que o Poder Judiciário, com seus juízes e cortes, não são, e não podem ser, a única forma de se acessar a justiça, haja vista o fenômeno da emergência de novos agentes que também tem a missão da produção de justiça, como é o caso do Sistema de Justiça, com seus promotores, procuradores, defensores, entre outros.

Vai-se além, todavia, desse raciocínio: a justiça não está apenas no Poder Judiciário ou no Sistema de Justiça, ou mesmo em qualquer outra área estatal, mas, sim, na sociedade ${ }^{84}$.

Para se falar no alargamento ${ }^{85}$ do direito ${ }^{86}$, primeiramente, deve-se observar a necessidade de simplificação dele. Cappelletti e Garth, no celebrado livro já referido, em 1978, a partir da perspectiva Norte-Oeste, já explicitavam, em termos pouco críticos, de forma descritiva, o quanto o nosso direito é complicado. Daí, apontavam que as ondas de ampliação do acesso à justiça teriam que passar, necessariamente, por um processo de descomplicação do direito, preceituando que "a simplificação é tanto desejável quanto possível"s7.

84 Neste item, não haverá espaço para se explorar todas as possibilidades de direito e justiça não-estatal. Lembrando que há, no Brasil, duas escolas muito fortes nesse sentido, que são a do pluralismo jurídico - a referência teórica é Antonio Carlos Wolkmer, da UFSC - e a do direito achado na rua - as referências teóricas são Roberto Lyra Filho, José Geraldo de Sousa Júnior e Alexandre Bernardino Costa, da UnB. A intenção, aqui, não é adentrar no tema em si, mas apenas fortalecer o argumento de que o direito não é encontrado apenas no âmbito do Estado; as organizações da sociedade civil, quando estão trabalhando, no seu dia a dia, com a normativa internacional, por exemplo, estão alargando o direito e promovendo a justiça.

85 Expressão inspirada no texto "Por uma concepção alargada de Acesso à Justiça", de José Geraldo de Sousa Júnior (2008), que será discutido nesse item.

86 Utiliza-se, nessa pesquisa, a concepção de direito dentro de seu sentido de produto cultural, tal como propõe Herrera Flores em relação aos direitos humanos. Utiliza-se, portanto, a expressão "direito" para se referir a essa estrutura jurídica que dá forma à nossa convivência social; a expressão "direitos" para se referir às normas específicas que são produzidas nesse contexto; e a expressão "Direito" para referir a disciplina na divisão dos saberes, apenas para distinguir "direito" de "Direito".

87 Cappelletti e Garth (1988) trazem à tona o tema da complicação do direito: "Nosso Direito é frequentemente complicado e, se não em todas, pelo menos na maior parte das áreas, ainda permanecerá assim. Precisamos reconhecer, porém, que ainda subsistem amplos setores nos quais a simplificação é tanto desejável quanto possível. Se a lei é mais compreensível, ela se torna mais acessível às pessoas comuns. No contexto do movimento de acesso à justiça, a simplificação também diz respeito à tentativa de tornar mais fácil que as pessoas satisfaçam as exigências para a utilização de determinado remédio jurídico." (CAPPELLETTI \& GARTH, 1988, p. 156) Nota-se que os autores não trabalham com a ideia de complexidade, mas sim de complicação, que seria uma ação deliberada dos "operadores do direito" de se tornaram imprescindíveis para a resolução de questões jurídicas. O problema é que virtualmente todas as questões sociais foram juricizadas, o que torna os "operadores do direito" sujeitos de enorme protagonismo político. Daí a necessidade da descomplicação do direito, mas, também, do retorno à política de questões que hoje se encontram juricizadas. Daí as propostas de democratização da justiça. 
Para além da simplificação do direito, tem-se de pensar em novos espaços e formas de se buscar e resolver questões envolvendo a justiça. Há uma tendência ainda vigente de criação e fortalecimento de instituições judiciais ou quase-judiciais ${ }^{88}$ a fim de estabelecer procedimentos que deem conta dessa necessidade. Aponta-se, contudo, para a urgência de reflexão, para o futuro, sobre estratégias relacionadas à justiça restaurativa, ou seja, fugir da criação ou reforço de mecanismos de judicialização.

Sousa Júnior produz uma reflexão que aponta para a necessidade de uma visão alargada do direito. De início, aponta que tal esforço necessita ser realizado a partir de uma problematização sobre o paradigma da modernidade ${ }^{89}$ : a) a modernidade - a partir de sua racionalidade científica e positiva - rejeita outras saberes, formas de conhecimento e de explicação da realidade; b) a modernidade - sob sua forma política, ou seja, o Estado subordinou outras de organização social, isolando-o como sua forma política por excelência; e c) a modernidade reduz o direito à sua expressão formal (codificação ou positivação), colonizando, a partir dessa perspectiva, "práticas jurídicas plurais inscritas nas tradições corporativas e comunitárias" (2008, p. 3).

A fim de se compreender na totalidade a proposta da mobilização do direito, tem-se de estar atento às possibilidades existentes junto da cidadania e da sociedade. $\mathrm{O}$ direito, acaso visto a partir de sua centralidade no Estado e na lei, não possui ferramentas para fornecer um olhar crítico sobre esse processo, quão menos para realizar a aproximação

88 Sonnenberg \& Cavallaro (2012) afirmam, ainda, sobre essa tendência: “Once rights abuses have been established, traditional rights advocacy focuses on efforts designed to investigate, prosecute, and punish wrongdoers and seek compensation for victims. Rights advocates routinely engage justice mechanismsdomestic investigations, prosecutions, international oversight bodies, and quasi-judicial and judicial structuresin order to seek accountability for past abuses. Because these institutions alone often fail to vindicate the rights of the oppressed, rights practitioners and rule of law consultants also frequently seek to intervene on a systemic level to improve the capacity of those judicial remedies to operate more effectively. Still, at the end of the twentieth century, one of the major focus areas of the human rights movement remained advocacy for the creation and strengthening of such judicial remedies, both at the domestic and increasingly at the international levels." (grifo meu) (SONNENBERG \& CAVALLARO, 2012, p. 261-262)

89 Sousa Júnior $(2008$, p. 3) assim esclarece: "Cabe por em relevo alguns pressupostos tanto teóricos quanto políticos que, na modernidade, contribuíram para facilitar o desenho desse monopólio [do Estado]. Com efeito, na discussão da questão da mediação popular de conflitos, uma estratégia de problematização desse tema aparece ancorada em três pilares, todos decorrentes de limites das condições de compreensão da realidade no paradigma da modernidade. Trata-se aqui da modernidade em seu sentido de tempo histórico e de racionalidade. Os três aspectos colocados em relevo são os seguintes: a modernidade compreendida como racionalidade científica e positiva que passou a rejeitar outras formas de conhecimento e de explicação da realidade, tais como as mítico-religiosas e as de natureza metafísica; a modernidade representada pela hegemonia da forma política do Estado, cuja expressão institucional passou a subordinar as experiências múltiplas de outros modos de organização política do espaço da sociedade; a modernidade caracterizada pela supremacia do modo legislativo de realizar o Direito, isolando o jurídico na usa expressão formal (codificação), por meio de uma colonização das práticas jurídicas plurais inscritas nas tradições corporativas e comunitárias" (SOUSA JÚNIOR, 2008, p. 3). 
necessária que deve ser feita junto às comunidades, organizações e movimentos, a fim de outras formas de direito sejam encontradas.

Esse esforço de aproximação nada mais é que a busca pelo direito e pela justiça, significando

(...) Mediar conflitos, portanto, requer atuar em uma situação de alteridade sem hierarquias, sejam as que opõem as práticas do social às prescrições da autoridade localizada do Estado; do Direito adjudicado por um especialista (juiz) a partir de um pauta restrita (o código, a lei), em relação a sujeitos que não são reconhecidos em suas identidades (ainda não constituídos plenamente como cidadãos) e que buscam construir a sua cidadania por meio de um protagonismo que procura o direito social, em um processo que antecede e sucede o procedimento legislativo e no qual, o Direito, que não se contêm apenas no espaço estatal e dos códigos é, efetivamente, achado na rua. (grifo meu) (SOUSA JÚNIOR, 2008, p. $5)$.

$\mathrm{O}$ direito e a justiça nada mais são do que instrumentos para a mediação de conflito, na busca pela paz social, como aqui já se destacou. O que a experiência da mobilização do direito, ou seja, o uso do direito pelas organizações da sociedade civil e os movimentos sociais têm demonstrado é que, em algumas circunstâncias, o direito proporciona resultados mais positivos, com maiores impactos, para esses grupos.

A prática do direito é contra-hegemônica quando ocorrem os eventos que se seguem: a) há alteridade e não hierarquia; b) não há autoridade, mas, sim, cooperação; c) não há especialistas, mas, sim, colaboradores; d) não há restrição à pauta de fatos e direitos que serão discutidos, mas, sim, a extensão adequada ao atendimento da demanda real dos indivíduos ou grupos envolvidos no conflito; e) não há indivíduos atomizados, mas, sim, sujeitos reconhecidos em suas identidades. Dessa forma, o direito não se sobrepõe à prática social, mas, sim, integra-se a ela; é o direito achado na rua.

Importante notar como essa perspectiva auxilia na análise do uso do Sistema Interamericano de Direitos Humanos pelas organizações da sociedade civil. Há uma restrição clara de acesso à justiça no Poder Judiciário e no Sistema de Justiça, apesar de esforços empreendidos pela sociedade brasileira nas últimas décadas. Algumas restrições são, inclusive, intrínsecas ao fato do sistema ser estatal e não poderão ser modificadas. Daí a relevância e a importância da mobilização do direito pelas organizações da sociedade civil.

Aqui, não se advoga que uma prática tenha que se sobrepor à outra, no sentido 
da extinção da prática jurídica estatal. Ambas devem ser utilizadas, na medida e no alcance em que se fizerem necessárias pelos indivíduos e grupos nos casos concretos, dentro do exercício da democracia ${ }^{90}$.

A proteção internacional dos direitos humanos, com sua normativa e seus órgãos de proteção, constitui-se, hoje, em um poderoso instrumento para as organizações da sociedade civil e movimentos sociais em todo o mundo. A mobilização transnacional do direito é um elemento essencial dessa proteção, para que sejam superados os limites postos, desde a sua origem, pela sua concepção liberal, individualista e legalista de direitos ${ }^{91}$. A afirmação do direito deve ir ao encontro da necessidade das vítimas, organizações e movimentos, e não, pelo contrário, a da garantia das práticas hegemônicas. Os direitos humanos e o alargamento do direito se dão, justamente, no campo da contra-hegemonia, mas não apenas em função de seu discurso, mas, também, em razão de suas práticas.

Ainda, José Manuel Pureza (2012, p. 10) pontua que o direito constitui-se em uma das ferramentas para o reconhecimento e concretização dos direitos humanos, fazendo a brilhante observação de que "(...) direitos humanos são sempre muito mais do que aquilo que o direito diz deles". Brilhante porque aponta para a natureza tanto de um, quanto de outro: enquanto os direitos humanos são transversais, perpassam uma série de dimensões, esferas, processos, o direito encontra-se no plano jurídico, lugar em que possui uma ação limitada.

De outro lado, o direito molda os direitos humanos, já que estes são sempre muito mais do que o direito os denomina. Inúmeras são as expressões possíveis do direito para os direitos humanos; entretanto, elege-se uma - ou outra - para dar-lhe densidade jurídica e, consequentemente, concretude na vida em sociedade, ao menos como a vivemos hoje. É uma relação delicada, muito íntima e, ao mesmo tempo, complexa, que se estabelece

90 Nesse sentido, Sousa Júnior (2008) argumenta da seguinte maneira: "O nível restrito do acesso à justiça, portanto, se reafirma no sistema judicial. O nível mais amplo do mesmo conceito se fortalece em espaços de sociabilidades que se localizam fora ou na fronteira do sistema de justiça. Contudo, ambos os níveis se referem a uma mesma sociedade, na qual se pretende o exercício constante da democracia" (SOUSA JÚNIOR, 2008 , p. 7).

91 No prefácio ao já citado livro coordenado por MacDowell Santos (2012), Pureza (p. 10) traça os contornos da mobilização transnacional do direito, trabalhando com as ideias de proteção internacional, legalidade cosmopolita e contra-hegemonia: "A mobilização transnacional do direito constitui um elemento essencial da afirmação de uma proteção internacional dos direitos humanos que supere os limites de uma concepção liberal, individualista e legalista dos direitos. $\mathrm{O}$ uso do direito e das instituições internacionais tem provado poder ser um fator de afirmação dessa legalidade cosmopolita alternativa em benefício das pessoas e dos povos. Como é óbvio, a mobilização do direito tanto é operada por atores que têm hegemonia na decisão da agenda económica e social global como por outros que vão abrindo espaços de contestação e dinâmicas de contra-hegemonia" (PUREZA, 2012, p. 10). 
entre o direito e os direitos humanos.

Antes de se reclamar a cisão entre direitos humanos e direito, ou mesmo a desnecessidade do uso do direito frente a magnitude moral e histórica dos direitos humanos $^{92}$, o desafio que se coloca no horizonte é de, justamente, realizar o contrário: devese mobilizar o direito de forma que ele funcione contra-hegemonicamente na luta pelos direitos humanos.

92 Pureza (2012) continua em sua argumentação sobre a mobilização transnacional do direito: (...) O direito é apenas uma das ferramentas para o reconhecimento e a aplicação dos direitos. A montante e a jusante do direito, a força dos direitos humanos tem muitas outras condicionantes. Mas engana-se quem pensar que o direito é irrelevante ou até inevitavelmente adverso para a ampliação do espaço dos direitos e a afirmação de uma agenda da dignidade contra todos os entendimentos hegemónicos que os espartilham e limitam. A história de tantos direitos - dos direitos das mulheres aos direitos dos trabalhadores e trabalhadoras, passando pelos direitos ambientais ou pelos direitos de diversidade cultural e social - mostra-nos que o uso sábio do direito, muitas vezes voltando-o contra os interesses sociais que o geraram ou confrontando-os com as contradições que uma aplicação plena desse seu direito lhes provoca, é uma arma poderosíssima." (PUREZA, 2012, p. 10) (grifo meu). 


\section{CAPÍTULO 2 - O PRESÍDIO PROFESSOR ANÍBAL BRUNO NO SISTEMA INTERAMERICANO DE DIREITOS HUMANOS}

No segundo capítulo dessa dissertação, restam expostos alguns conceitos, dados e informações relevantes para a compreensão do caso Aníbal Bruno. Em primeiro lugar, é necessário uma explanação, mesmo que sucinta, a respeito do Sistema Interamericano de Direitos Humanos, o espaço político e jurídico escolhido pelas organizações da sociedade civil para confronto com o Estado brasileiro a respeito das violações de direitos humanos ocorridas na unidade prisional Aníbal Bruno. Para uma compreensão resumida do Sistema, deve-se atentar para sua normativa e meios de proteção - Comissão e Corte - que são os instrumentos que concretizam a proteção que o Sistema pretende para os direitos humanos no plano da Organização dos Estados Americanos. Ainda, faz-se relevante apontar como se encontram as relações entre o SIDH e o Estado brasileiro, particularmente no que se refere aos casos de violação de direitos humanos dentro do sistema prisional brasileiro.

Logo depois, adentra-se no debate específico sobre o sistema prisional brasileiro, com a atualidade dos temas sobre superencarceramento e a miséria nas e das suas prisões. Isso porque o caso Aníbal Bruno está dentro de um contexto de uma série de violações de direitos humanos: são várias as violações que ocorrem nas unidades, e, ainda, a maioria das unidades do Brasil apresentam as mesmas violações que ocorrem no Presídio Professor Aníbal Bruno. Tal afirmação não se baseia somente em informações produzidas pela sociedade civil no Brasil, mas também em dados produzidos por órgãos estatais. Se o caso Aníbal Bruno encontra-se num contexto maior de violações, não se pode pensar em soluções que estejam desconectadas das soluções para os outros casos. Trata-se, portanto, de um problema estrutural, que deve ser tratado de forma estrutural, para sua melhor compreensão e possibilidade de encaminhamento de solução. Procura-se, daí, expor a atual situação do sistema prisional brasileiro por meio de dados produzidos por inúmeros órgãos do país, que possuem a missão de controlá-lo e monitorá-lo. Ainda, demonstram-se as potencialidades do Estado brasileiro - tanto em relação à sua normativa progressista, quanto aos inúmeros e diversificados mecanismos estatais relacionados ao controle e monitoramento do sistema prisional. Expõe-se, assim, a perplexidade de um estado de coisas - as violações maciças de direitos humanos nas prisões - que não se justifica, sob as condições em que existem - a riqueza de normativa e mecanismos estatais. 
$\mathrm{Na}$ terceira parte do capítulo, trata-se especificamente do caso Aníbal Bruno. O trabalho das organizações da sociedade civil, representantes dos beneficiários das medidas cautelares - no âmbito da CIDH. Em seguida apresentam-se as medidas provisórias - no âmbito da Corte IDH - a partir da experiência das organizações na mobilização do direito internacional dos direitos humanos, consubstanciado no ingresso da demanda junto ao Sistema Interamericano de Direitos Humanos. Analisam-se as suas manifestações enviadas à Comissão Interamericana de Direitos Humanos, no período compreendido entre 2011 e 2014; examinam-se as medidas cautelares outorgadas pela Comissão em 2011 e 2012, as manifestações da sociedade civil e, ainda, a remessa pela CIDH do caso à Corte Interamericana em 2014. Da mesma forma, são trazidos os principais elementos das manifestações dos representantes dos beneficiários, assim como as medidas provisórias decretadas pela Corte Interamericana de Direitos Humanos em 2014 e 2015.

\subsection{O Sistema Interamericano de Direitos Humanos}

O Sistema Interamericano de Direitos Humanos constitui-se no conjunto de instrumentos normativos e estruturas institucionais, parte da Organização dos Estados Americanos $^{93}$, criados no sentido de promover e defender os direitos humanos em todo o continente americano.

Seus principais instrumentos normativos são a Carta da OEA, a Declaração Americana de Direitos e Deveres do Homem e a Convenção Americana sobre Direitos Humanos, também conhecida como Pacto de São José da Costa Rica. Juntamente com esses, há uma série de outros instrumentos, conhecidos como documentos básicos ${ }^{94}$ do Sistema

93 A OEA é uma organização internacional constituída, atualmente, por 35 Estados: Antígua e Barbuda, Argentina, Bahamas, Barbados, Belize, Bolívia, Brasil, Canadá, Chile, Colômbia, Costa Rica, Cuba, Dominica, Equador, El Salvador, Estados Unidos da América, Granada, Guatemala, Guiana, Haiti, Honduras, Jamaica, México, Nicarágua, Panamá, Paraguai, Peru, República Dominicana, Santa Lúcia, São Cristóvão e Nevis, São Vicente e Granadinas, Suriname, Trinidad e Tobago, Uruguai e Venezuela. Disponível em $<$ www.oas.org/pt/estados membros/autoridades.asp $>$, acesso em junho de 2015.

94 Os documentos básicos do Sistema Interamericano de Direitos Humanos são os que se seguem: i) a Convenção Interamericana para Prevenir e Punir a Tortura; ii) o Protocolo Adicional à Convenção Americana sobre Direitos Humanos em Matéria de Direitos Econômicos, Sociais e Culturais; iii) o Protocolo Adicional à Convenção Americana sobre Direitos Humanos relativo à Abolição da Pena de Morte; iv) a Convenção Interamericana para Prevenir, Punir e Erradicar a Violência contra a Mulher; v) a Convenção Interamericana sobre Desaparecimento Forçado de Pessoas; vi) a Convenção Interamericana para a Eliminação de Todas as Formas de Discriminação contra Pessoas com Deficiência; vii) a Convenção Interamericana contra o Racismo, a Discriminação Racial e Formas Conexas de Intolerância; viii) a Convenção Interamericana contra toda Forma de Discriminação e Intolerância; $i x$ ) a Declaração de Princípios sobre Liberdade de Expressão; $x$ ) a Carta Democrática Interamericana; e xi) os Princípios e Boas Práticas sobre a Proteção a Pessoas Privadas de Liberdade nas Américas. Além desses, são referidos os Estatutos e Regulamentos da CIDH e Corte IDH. 
Interamericano de Direitos Humanos.

Quanto à estrutura institucional do SIDH, seus meios de proteção são a Comissão Interamericana de Direitos Humanos e a Corte Interamericana de Direitos Humanos, encarregadas da supervisão do cumprimento dos direitos reconhecidos nos instrumentos normativos sobre direitos humanos em seu âmbito.

\subsubsection{A normativa interamericana de proteção dos direitos humanos}

A Organização dos Estados Americanos foi fundada em maio de 1948 em Bogotá, Colômbia, durante a IX Conferência Interamericana. Após décadas de trajetória, a Organização desenvolveu sua estratégia de trabalho com base em quatro pilares fundamentais, que são a democracia, os direitos humanos, a segurança e o desenvolvimento. A Carta da Organização dos Estados Americanos ${ }^{95}$ dá-lhe estrutura normativa, dispondo, em seu artigo $1^{\circ}$, que a Organização visa

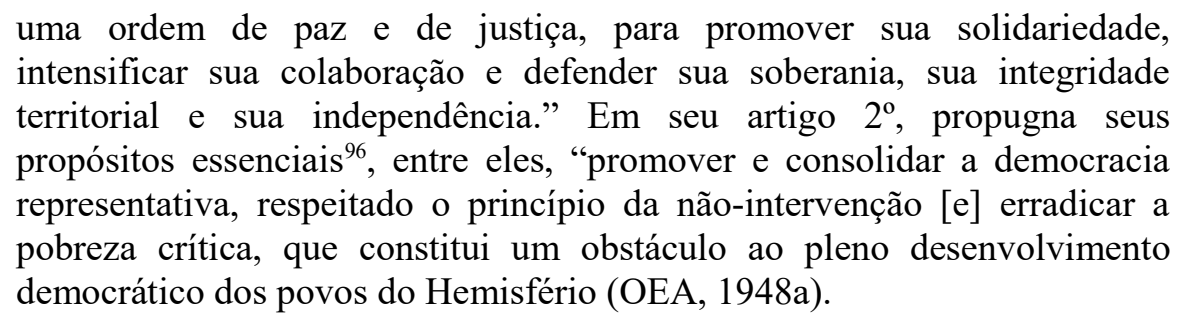

Contudo, para além de se ater ao texto do documento, importante notar que a Carta da OEA estabelece, fundamentalmente, parâmetros para a relação jurídica entre os Estados membros da Organização uns em relação aos outros, como nos artigos 10 a 23, ao instituir direitos e deveres fundamentais dos Estados. Diferentemente da Carta da OEA, a Declaração Americana de Direitos e Deveres do Homem (DADDH) possui, como sua

Disponível em < www.oas.org/es/cidh/mandato/documentos basicos.asp $>$, acesso em junho de 2015 .

95 Promulgada em 1948, foi emendada pelos Protocolos de Buenos Aires (1967), de Cartagena das Índias (1985), de Washington (1992) e de Manágua (1993).

96 O artigo $2^{\circ}$ da Carta da OEA dispõe o que se segue: “a) Garantir a paz e a segurança continentais; b) Promover e consolidar a democracia representativa, respeitado o princípio da não-intervenção; c) Prevenir as possíveis causas de dificuldades e assegurar a solução pacífica das controvérsias que surjam entre seus membros; d) Organizar a ação solidária destes em caso de agressão; e) Procurar a solução dos problemas políticos, jurídicos e econômicos que surgirem entre os Estados membros; f) Promover, por meio da ação cooperativa, seu desenvolvimento econômico, social e cultural; g) Erradicar a pobreza crítica, que constitui um obstáculo ao pleno desenvolvimento democrático dos povos do Hemisfério; e h) Alcançar uma efetiva limitação de armamentos convencionais que permita dedicar a maior soma de recursos ao desenvolvimento econômico-social dos Estados membros." 
centralidade, os direitos e deveres das pessoas, ou seja, constitui-se fundamentalmente em um documento de salvaguarda dos direitos dos cidadãos frente ao poder exercido pelo Estado.

Apesar de alguns antecedentes históricos ${ }^{97}$, pode-se afirmar que a Declaração Americana de Direitos e Deveres do Homem, juntamente com a Carta da OEA, formam a base normativa central do Sistema Interamericano de Direitos Humanos (CANÇADO TRINDADE, 2003, p. 33), ao traçar uma perspectiva geral, e não mais segmentada, sobre a proteção dos direitos do ser humano.

A DADDH, adotada em maio de 1948, na mesma IX Conferência Internacional Americana, em Bogotá, Colômbia, é o primeiro instrumento internacional de direitos humanos de caráter geral. Em seus considerandos, declara que

em repetidas ocasiões, os Estados americanos reconheceram que os direitos essenciais do homem não nascem do fato de ser nacional de determinado Estado, mas sim como fundamento dos atributos da pessoa humana" e que "a proteção internacional dos direitos do homem deve ser guia principalíssima do direito americano em evolução (OEA, 1948).

Tanto o argumento de que o fundamento da normativa de direitos humanos é a pessoa humana - e daí podemos inferir sua dignidade - quanto o de que a proteção internacional dos direitos humanos deve ser o condutor do direito americano em construção, foram de extrema vanguarda na época, sendo uma importante referência para todos os documentos supervenientes.

O texto da Declaração Americana conta com 38 artigos, divididos entre dois capítulos. O primeiro capítulo estabelece os direitos ${ }^{98}$; o segundo, os deveres ${ }^{99}$. A fim de esclarecer a relação entre direitos e deveres, fica estabelecido, em seu preâmbulo, que

97 Instrumentos jurídicos antecedentes ao Sistema Interamericano: Convenção sobre Direitos dos Estrangeiros (1902); Convenção sobre o Estatuto de Cidadãos Naturalizados (1906), Convenção sobre o Estatuto dos Estrangeiros (1928); Convenção sobre o Asilo (1928); Convenções sobre Asilo Diplomático e Asilo Territorial (1954); Convenções Interamericanas sobre Direitos Políticos e Civis da Mulher (1948).

98 Entre os direitos, que são ao todo 28 , destacam-se, em razão do tema da investigação, o direito à vida, à liberdade, à segurança e à integridade da pessoa (art. $1^{\circ}$ ); direito de igualdade perante a lei (art. $2^{\circ}$ ); direito à justiça, de petição e ao devido processo (arts. 18, 24 e 26); e direito à proteção contra a detenção arbitrária (art. 25).

99 Já os deveres estão em menor número - por isso são reproduzidos integralmente aqui -, sendo ao todo 10: deveres perante a sociedade (art. 29); deveres para com os filhos e pais (art. 30); dever de instrução (art. 31); dever de voto (art. 32), dever de obediência à lei (33); dever de servir à comunidade e à nação (art. 34); deveres de assistência e seguridade sociais (art. 35); dever de pagar impostos (art. 36); dever de trabalho (art. 37); dever de se abster de atividades políticas em país estrangeiro (art. 38). 
(...) o cumprimento do dever de cada um é exigência do direito de todos. Direitos e deveres integram-se correlativamente em toda a atividade social e política do homem. Se os direitos exaltam a liberdade individual, os deveres expressam a dignidade dessa liberdade (OEA, 1948).

Importante notar que essa construção do Sistema Interamericano de Direitos Humanos deu-se dessa forma em função de determinadas características históricas, políticas, sociais, econômicas e culturais ${ }^{100}$. Existem, paralelamente a essa experiência americana, outros sistemas regionais já estabelecidos, que são o europeu e o africano ${ }^{101}$. Há de se fazer, ainda, referência ao Sistema Universal de Direitos Humanos ${ }^{102}$ e sua relação com o Sistema Interamericano de Direitos Humanos. As Nações Unidas e os sistemas regionais funcionam de maneira conjunta, com a finalidade de proteger e promover direitos humanos da maneira mais eficaz o possível. A universalidade não significa a supressão do plano regional, no sentido de que "não equivale à uniformidade total; ao contrário, é enriquecida pelas particularidades regionais" (CANÇADO TRINDADE, 2003, p. 30).

A respeito de sua força normativa, tanto a Comissão quanto a Corte já estabeleceram que, apesar de ter sido adotada como uma declaração e não como um tratado, na verdade, a Declaração Americana de Direitos e Deveres do Homem constitui fonte de obrigação internacional para os Estados membros da OEA ${ }^{103}$.

100 Antônio Augusto Cançado Trindade (2003, p. 30) pontua que a particularidade de cada sistema de proteção tem suas características determinadas pela sua própria realidade: "Cada sistema regional tem funcionado, pois, em seu próprio ritmo, e, atento à realidade dos direitos humanos em seu continente respectivo, tem vivido seu momento histórico e seguido sua própria trajetória."

101 Existem, atualmente, três sistemas regionais de Direitos Humanos consolidados, que são de grande importância para o fortalecimento do discurso e prática dos direitos humanos em nível global. O Sistema Europeu tem como base a Convenção Europeia de Direitos Humanos de 1950, com entrada em vigor em 1953. O Sistema Interamericano, a Convenção Americana de Direitos Humanos, também conhecida como Pacto de San José da Costa Rica, de 1969, com entrada em vigor em 1979. O Sistema Africano tem como documento fundamental a Carta Africana dos Direitos Humanos e dos Povos de 1981, com entrada em vigor em 1986. Em 16 dezembro de 1977, a Assembleia Geral da ONU, em sua 105 ${ }^{\text {a }}$ Reunião Ordinária, passou a acolher formalmente a formação de sistemas regionais e, especialmente, a incentivar acordos regionais de direitos humanos nas áreas onde inexistissem tais acordos, conforme Resolução 32/127 de 1977 (PIOVESAN, 2011a, pp. 99 e ss).

102 Ramos (2013, p. 77) explica, da seguinte forma, o Sistema protetivo das Nações Unidas: "A apuração das violações de direitos humanos no âmbito da Organização das Nações Unidas é complexa e dividida em duas áreas: a área convencional, originada por acordos internacionais, elaborados sob a égide da ONU, dos quais são signatários os Estados, e a área extraconvencional, originada de resoluções da Organização das Nações Unidas e seus dispositivos relativos à proteção dos direitos humanos. Ambas (a convencional e a extraconvencional) formam o sistema onusiano, universal ou global de proteção de direitos humanos, assim denominado por ter sua origem na Carta da Organização das Nações Unidas e seus dispositivos relativos à proteção dos direitos humanos".

$103 \mathrm{O}$ mesmo fenômeno ocorre com a DUDH no Sistema ONU. A discussão aqui é sobre a diferença entre as normas estabelecidas por uma declaração e por um tratado, quanto à sua eficácia. Para a tradicional doutrina do Direito Internacional Público, faz-se a distinção entre a eficácia de uma norma de hard law e de soft law. Contudo, de acordo com entendimento do Direitos Internacional dos Direitos Humanos, pode-se afirmar que as 
Desde sua criação, a OEA tem produzido uma série de instrumentos internacionais que se converteram na base normativa do Sistema Regional de Promoção e Proteção dos Direitos Humanos. É chamado e reconhecido como "sistema" justamente porque há o reconhecimento dos direitos das pessoas, nacionais de seus estados membros, assim como o estabelecimento de obrigações para esses Estados, no sentido dessa mesma promoção e proteção dos direitos humanos, e, ainda, a existência de órgãos supranacionais e especializados em direitos humanos, que realizam o monitoramento da sua situação no continente.

A Convenção Americana sobre os Direitos Humanos ${ }^{104}$, ou Pacto de São José da Costa Rica - o mais importante e potente instrumento de proteção dos direitos humanos do Sistema -, foi adotada pela Assembleia Geral da OEA em 22 de novembro de 1969, no âmbito da Conferência Especializada Interamericana sobre Direitos Humanos. Os antecedentes da Convenção Americana remontam a Conferência Interamericana realizada no México em 1945, em que se encomendou ao Comitê Jurídico Interamericano a preparação de um projeto de Declaração. Essa ideia foi retomada na $5^{\text {a }}$ Reunião de Consulta de Ministros de Relações Exteriores, em Santiago do Chile, em agosto de 1959 ${ }^{105}$. Nessa oportunidade, decidiu-se impulsionar a preparação de um tratado de direitos humanos. $\mathrm{O}$ projeto original da Convenção foi elaborado pelo Conselho Interamericano de Jurisconsultos, submetido ao Conselho da OEA e sujeito a comentários pelos Estados e pela Comissão Interamericana de Direitos Humanos. Em 1967, a Comissão apresentou novo projeto de Convenção. Para analisar os diferentes projetos, a OEA convocou uma Conferência Especializada Interamericana sobre Direitos Humanos, que se reuniu em San José da Costa Rica, no período entre 7 e 22 de novembro de 1969 (CANÇADO TRINDADE, 2003, p. 42).

Atualmente, a Convenção Americana conta com a adesão de 23 países ${ }^{106}$. Desde sua adoção pela Assembleia Geral, dois países ratificaram o instrumento e, anos depois,

Declarações, tanto a Universal quanto a Americana, possuem eficácia similiar a de hard law, em face de seu compromisso histórico. Sobre o debate do valor jurídico da DUDH, ver Piovesan, $2011 \mathrm{~b}$.

104 A Convenção Americana de Direitos Humanos foi ratificada pelo Estado brasileiro em 25 de setembro de 1992. O Decreto n. 678, de 6 de novembro de 1992, promulga a Convenção Americana sobre Direitos Humanos (Pacto de San José da Costa Rica), de 22 de novembro de 1969.

105 Nessa mesma Reunião, decidiu-se pela criação da CIDH, como se verá a seguir.

106 São signatários da CADH os seguintes países: Argentina, Barbados, Bolívia, Brasil, Chile, Colômbia, Costa Rica, Dominica, Equador, El Salvador, Grenada, Guatemala, Haiti, Honduras, Jamaica, México, Nicarágua, Panamá, Paraguai, Peru, República Dominicana, Suriname, Uruguai. Disponível em $<$ www.oas.org/dil/esp/tratados B-32 Convencion_Americana_sobre_Derechos_Humanos firmas.htm $>$, acesso em junho de 2015 . 
denunciaram-no: Trinidad e Tobago e Venezuela, que, respectivamente, ratificaram-no em 1991 e 1977, finalmente, denunciando o tratado em 1998 e $2012^{107}$. O conjunto de países que são parte da Convenção encontram-se obrigados internacionalmente por meio de suas regras. No preâmbulo, importante a afirmação de que a proteção internacional é de natureza coadjuvante ou complementar em relação à oferecida no direito interno dos Estados membros. A entrada em vigor da Convenção Americana ocorreu em 18 de julho de 1978, quase dez anos após sua criação ${ }^{108}$. A vigência da $\mathrm{CADH}$, entre outros avanços, permitiu incrementar a efetividade da Comissão, estabelecer uma Corte Interamericana de Direitos Humanos e modificar a natureza jurídica dos instrumentos que dá base para sua estrutura institucional.

O Brasil, assim como outros países da OEA, estavam, à época da criação da Convenção Americana de Direitos Humanos, vivendo regimes autoritários, em que violações de direitos humanos eram cometidos de forma maciça ${ }^{109}$. Por que o processo foi, então, adiante, com a participação do Brasil? A resposta estaria num esforço para manter as aparências de regime democrático, o que foi amplamente buscado pelos governos militares que se sucederam no Brasil por mais de vinte anos e, em especial, pelo governo do General Garrastazu Médici, presidente durante um dos períodos em que a ditadura mostrou sua face mais cruel no país, coincidindo, em grande parte, com o processo de debate e coleta de assinaturas da Convenção Americana de Direitos Humanos (RAMOS, 2013, p. 214).

Quanto ao seu conteúdo, os dois artigos que sustentam juridicamente a $\mathrm{CADH}-$ no sentido da responsabilização internacional dos Estados - são os $\operatorname{artigos~} 1^{\circ}$ e $2^{\circ}$. O artigo $1^{\mathrm{o}_{110}}$ dispõe que os Estados comprometem-se a respeitar os direitos e liberdades nela

107 Para maiores informações sobre esses dois casos de denúncia da Convenção Americana de Direitos Humanos, cf.

$<$ www.oas.org/dil/esp/tratados B32 Convencion Americana sobre Derechos Humanos firmas.htm>, acesso em junho de 2015.

$10 \overline{8}$ A CADH demorou quase dez anos para entrar em vigor em razão de regra de seu próprio texto convencional que, em seu art. 74, determina que "Tão logo 11 Estados tenham depositado seus respectivos instrumentos de ratificação ou adesão, a Convenção entrará em vigor.” A demora do Estados em ratificar ou aderir ao tratado é expressão da instabilidade política vivida na região àquela época.

109 Ramos (2013, p. 214) explica o paradoxo vivido no caso brasileiro: "Paradoxalmente, essa mesma Ditadura Militar, sob o comando do General Presidente Emílio Garrastazu Médici (que havia tomado posso em outubro de 1969, sucedendo uma Junta Militar), enviou representantes à Conferência de San José da Costa Rica, que foram recebidos normalmente pela OEA e participaram das discussões e votações. Médici, ao longo de seu mandato, tornou-se símbolo de violações maciças de direitos humanos do regime militar, tendo ocorrido em seu governo a prática de desaparecimento forçado e crimes contra a humanidade. Esse paradoxo pode ser explicado pela tentativa de ditaduras da época (e, consequentemente da OEA, organização intergovernamental) de transmitir uma aparência de normalidade e semelhança com outros Estados da sociedade internacional, obtendo, com isso, legitimação e apoio para sua perpetuação. Para tanto, nada melhor que mimetizar o discurso de respeito a direitos humanos e democracia, mesmo sem qualquer intenção de pô-lo em prática."

$110 \mathrm{O}$ artigo $1^{\circ}$ da CADH dispõe sobre a "Obrigação de respeitar os direitos" da seguinte forma: "1. Os 
reconhecidos e garantir livre e pleno exercício a toda pessoa sujeita à sua jurisdição, sem qualquer discriminação. Chama-se, usualmente, tal compromisso de "obrigação de respeitar os direitos". O artigo $2^{\text {ol11 }}$ determina que os Estados comprometem-se no sentido da adoção das medidas legislativas e de outro caráter que forem necessárias para efetivar tais direitos e liberdades. Essa obrigação é recorrentemente denominada de "dever de adotar disposições de direito interno".

Quanto à estrutura dos direitos, a Convenção Americana reconhece 23 direitos civis e políticos, entre eles o direito à vida $\left(\operatorname{art.} 4^{\circ}\right)$, o direito à integridade pessoal $\left(\operatorname{art.} 5^{\circ}\right)$, a proibição da escravidão e da servidão (art. $6^{\circ}$ ), garantias judiciais (art. $8^{\circ}$ ), igualdade perante a lei (art. 24) e proteção judicial (art. 25), entre outros. Não existe previsão de direitos econômicos, sociais e culturais na $\mathrm{CADH}$, distinguindo-se, nesse ponto, o processo interamericano do universal, já que, no âmbito das Nações Unidas, houve a adoção de dois Pactos - o Pacto Internacional de Direitos Civis e Políticos (PIDCP) e o Pacto Internacional de Direitos Econômicos Sociais e Culturais (PIDESC) ${ }^{112}$-, ambos com o mesmo status de vinculação obrigacional para os Estados, o que não ocorre no SIDH $^{113}$. Entretanto, há previsão sobre a matéria no artigo 26, que encerra todo o conteúdo do Capítulo III, sobre Direitos Econômicos, Sociais e Culturais ${ }^{114}$.

Estados-partes nesta Convenção comprometem-se a respeitar os direitos e liberdades nela reconhecidos e a garantir seu livre e pleno exercício a toda pessoa que esteja sujeita à sua jurisdição, sem discriminação alguma, por motivo de raça, cor, sexo, idioma, religião, opiniões políticas ou de qualquer outra natureza, origem nacional ou social, posição econômica, nascimento ou qualquer outra condição social. 2. Para efeitos desta Convenção, pessoa é todo ser humano."

$111 \mathrm{O}$ artigo $2^{\circ}$ da CADH determina o chamado "dever de adotar disposições de direito interno", nos seguintes termos: "Se o exercício dos direitos e liberdades mencionados no artigo 1 ainda não estiver garantido por disposições legislativas ou de outra natureza, os Estados-partes comprometem-se a adotar, de acordo com as suas normas constitucionais e com as disposições desta Convenção, as medidas legislativas ou de outra natureza que forem necessárias para tornar efetivos tais direitos e liberdades."

112 Em 1966, sobrevieram, no âmbito das Nações Unidas, dois instrumentos de proteção de direitos humanos - o Pacto Internacional dos Direitos Civis e Políticos e o Pacto dos Direitos Econômicos Sociais e Culturais que deram origem à chamada Carta Internacional dos Direitos Humanos. Foram sucedidos, após, por várias convenções internacionais, todas com força vinculante para os países signatários, e que permitem, hoje, afirmar-se a existência de um sistema internacional de Direitos Humanos, com força jurídica, embora ainda não inteiramente consolidado (PIOVESAN, 2011a, p. 216-217).

113 O Protocolo Adicional à Convenção Interamericana Sobre Direitos Humanos em Matéria de Direitos Econômicos, Sociais e Culturais, também denominado de Protocolo de San Salvador, de 17 de novembro de 1988, ratificado pelo Brasil em 21 de agosto de 1996, com entrada em vigor prevista no próprio texto do Protocolo em 16 de novembro de 1999, é o instrumento normativo, no âmbito da OEA, que assegura direitos econômicos, sociais e culturais. O Decreto que o promulga é de n. 3.321, de 30 de dezembro de 1999.

114 Reproduz-se, aqui, o art. 26 da CADH: "Artigo 26 - Desenvolvimento progressivo. Os Estados-partes comprometem-se a adotar as providências, tanto no âmbito interno, como mediante cooperação internacional, especialmente econômica e técnica, a fim de conseguir progressivamente a plena efetividade dos direitos que decorrem das normas econômicas, sociais e sobre educação, ciência e cultura, constantes da Carta da Organização dos Estados Americanos, reformada pelo Protocolo de Buenos Aires, na medida dos recursos disponíveis, por via legislativa ou por outros meios apropriados." Existem muitas críticas em relação a essa 
O artigo 28 da Convenção Americana de Direitos Humanos ${ }^{115}$ é de grande relevância para países como o Brasil, Argentina e México, devido à forma de estado adotada nesses países - a federação. A cláusula federal determina que o governo nacional cumprirá todas as disposições da $\mathrm{CADH}$, relacionadas a matérias sobre as quais tenha competência legislativa e judicial. Ainda, a cláusula estabelece que, quanto às matérias de competência dos estados federados, o governo nacional deve tomar as medidas pertinentes, em conformidade com sua Constituição e leis, para que as autoridades estaduais competentes adotem as disposições cabíveis para o cumprimento da Convenção. É uma norma de garantia de efetividade da Convenção Interamericana, visto que busca evitar que os Estados e seus estados federados tentem burlar as suas obrigações convencionais, utilizando como justificativa para sua inércia a autonomia do ente federado.

Para além da Declaração Americana sobre os Direitos e Deveres do Homem e da Convenção Americana de Direitos Humanos, a OEA tem produzido, ao longo dos anos, uma série de importantes instrumentos normativos que visam à proteção e defesa de determinados direitos humanos no continente americano. Dentro do processo de especificação dos direitos humanos ${ }^{116}$, a tendência atual do Direito Internacional dos Direitos Humanos é a da produção de instrumentos particulares para dar conta de situações de violações específicas de um determinado grupo de pessoas. O que ocorre no momento de monitoramento e supervisão do cumprimento de tais compromissos pelos Estados é que, na maioria das vezes, a Convenção Americana é evocada para a proteção de determinado direito, conjuntamente com outro instrumento, ocorrendo o fenômeno da densificação

diferença de tratamento entre direitos civis e políticos face aos econômicos, sociais e culturais no âmbito interamericano. Contudo, como esse tema foge ao interesse da presente dissertação, não haverá aprofundamento dos debates.

$115 \mathrm{O}$ art. 28 da CADH, que traz a cláusula federal, dispõe o que se segue: "Artigo 28. Cláusula federal. 1. Quando se tratar de um Estado-parte constituído como Estado federal, o governo nacional do aludido Estadoparte cumprirá todas as disposições da presente Convenção, relacionadas com as matérias sobre as quais exerce competência legislativa e judicial. 2. No tocante às disposições relativas às matérias que correspondem à competência das entidades componentes da federação, o governo nacional deve tomar imediatamente as medidas pertinentes, em conformidade com sua Constituição e com suas leis, a fim de que as autoridades competentes das referidas entidades possam adotar as disposições cabíveis para o cumprimento desta Convenção. 3. Quando dois ou mais Estados-partes decidirem constituir entre eles uma federação ou outro tipo de associação, diligenciarão no sentido de que o pacto comunitário respectivo contenha as disposições necessárias para que continuem sendo efetivas no novo Estado, assim organizado, as normas da presente Convenção."

116 "Especificação dos direitos" é um processo apontado por Bobbio (2000, p. 482), por meio do qual vieram a ser contempladas novas pretensões e demandas relativas a direitos humanos, decorrentes tanto do surgimento de que se poderia chamar de novos sujeitos, quanto da emergência de demandas específicas. Ao tratar da questão do feminismo, Gregorio Peces-Barba define o processo de especificação dos direitos como um avanço do historicismo sobre o racionalismo, na perspectiva da "idea de considerar a los derechos más vinculados a las personas concretas de sus titulares" (apud GARCÍA-MUÑOZ, 2001, p. 5). 
normativa, ampliando, assim, a capacidade de proteção do Sistema Interamericano de Direitos Humanos.

Nesse sentido, a OEA produziu uma série de instrumentos normativos que vem ao encontro dessa tendência de ampliação protetiva. Apontam-se, a seguir, apenas os instrumentos que têm relação com a proteção das pessoas privadas de liberdade ${ }^{117}$, por conta do recorte do presente objeto de pesquisa.

A Convenção Interamericana para Prevenir e Punir a Tortura (CIPPT) ${ }^{118}$, adotada em 9 de dezembro de 1985 e com entrada em vigor em 28 de fevereiro de 1987, emprestou contornos de alta expressão política e normativa para o tema no continente americano. $\mathrm{O}$ texto convencional possui detalhada definição de tortura, assim como da responsabilização do agente estatal pelo cometimento do delito. Os Estados partes não apenas se comprometem a punir de forma severa a tortura, mas também se obrigam, dentro de suas respectivas jurisdições, a adotar medidas para prevenção e sanção de qualquer outro tratamento cruel, desumano ou degradante. Nota-se que o texto convencional possui mecanismo para evitar que pessoas acusadas do crime de tortura fujam do território onde cometeram tais atos, sob pena de serem extraditados para fins de processamento da respectiva ação penal.

Os Princípios e Boas Práticas sobre a Proteção das Pessoas Privadas de Liberdade nas Américas ${ }^{119}$ foram elaborados e adotados pela CIDH no $131^{\circ}$ Período Ordinário de Sessões, realizado entre 3 a 14 de março de 2008. Os Princípios e Boas Práticas estabelecem uma série de princípios relativos às pessoas submetidas a qualquer regime de privação de liberdade, dispondo que privação de liberdade consiste em

117 A expressão "pessoas privadas de liberdade" é utilizada pela CIDH para tratar de presos, mas também de outras situações em que existem pessoas custodiadas pelo Estado. No caso brasileiro, são abrangidos também pela expressão os adolescentes em cumprimento de medida socioeducativa.

118 Fazem parte da CIPPT 18 Estados: Argentina, Bolívia, Brasil, Chile, Colômbia, Costa Rica, Equador, El Salvador, Guatemala, México, Nicarágua, Panamá, Paraguai, Peru, República Dominicana, Suriname, Uruguai, Venezuela. Disponível em <www.oas.org/juridico/spanish/firmas/a-51.html $>$, acesso em junho de 2015. A Convenção Interamericana para Prevenir e Punir a Tortura, de 9 de dezembro de 1985, foi ratificada pelo Estado brasileiro em 20 de julho de 1989. O decreto que a promulga é de n. 98.386 de 9 de novembro de 1989. 119 Os Princípios e Boas Práticas sobre a Proteção das Pessoas Privadas de Liberdade nas Américas é um documento aprovada na Assembleia Geral da OEA, não necessitando passar pelo processo de um tratado como a CADH ou a CIPPT. Possui uma densidade normativa reduzida, em relação a esses outros diplomas; contudo, realizando-se uma interpretação conjunta dos artigos, as normas reforçam-se mutuamente. Além disso, interessante notar que se pode traçar um paralelo entre os "Princípios e Boas Práticas" com as regras Mínimas para Tratamento de Presos das Nações Unidas, que é um instrumento normativo das Nações Unidas que dispõe sobre as condições de encarceramento de pessoas privadas de liberdade, assim como o equivalente interamericano. 
(...) qualquer forma de detenção, encarceramento, institucionalização ou custódia de uma pessoa, por razões de assistência humanitária, tratamento, tutela, proteção ou por delitos e infrações à lei, determinada por ou sob o controle de fato de uma autoridade judicial ou administrativa ou qualquer outra autoridade, podendo ser uma instituição pública ou privada, na qual a pessoa não possa dispor de sua liberdade ambular. (CIDH, 2008)

Nesse sentido, a definição abarca não apenas as pessoas condenadas em função do cometimento de crimes, mas também as que estão sob a custódia e responsabilidade de instituições estatais, em que haja restrição de seu direito de ir e vir. Entre os princípios indicados no instrumento, encontram-se os de caráter geral (trato humano, igualdade e nãodiscriminação, devido processo legal, entre outros) e os relacionados com as condições de detenção das pessoas privadas de liberdade (saúde, alimentação, água potável, moradia, condições de higiene e vestimenta, medidas contra a superlotação, contato com o mundo exterior, trabalho e educação, entre outros).

\subsubsection{A Comissão e a Corte Interamericana de Direitos Humanos}

Voltando ao exame da Convenção Americana sobre Direitos Humanos, em sua segunda parte, encontram-se os capítulos que versam sobre os meios de proteção, a saber a estrutura normativa básica da Comissão e Corte Interamericana de Direitos Humanos ${ }^{120}$. O Sistema Interamericano de Direitos Humanos não é somente feito de normas de Direito Internacional dos Direitos Humanos. Afinal, que relevância prática há para as normas sem instituições e pessoas que possam interpretá-las e aplicá-las, emprestando-lhes concretude?

Nesse sentido, Ramos (2013, p. 32) adverte que

Logo, são justamente os mecanismos internacionais de apuração das violações de direitos humanos que conferem uma carga de ineditismo e relevância aos diplomas normativos internacionais de direitos humanos. De fato, atualmente, o Direito interno já reproduz - em linhas gerais - o rol internacional de direitos humanos protegidos, devendo agora o estudo recair sobre as fórmulas internacionais de obrigar o Estado a proteger tais direitos. Sem tal vinculação entre os mecanismos de apuração de violação de obrigações internacionais e os direitos humanos, estaremos

120 Reproduz-se, aqui, o dispositivo fundamental: “Art. 33. São competentes para conhecer de assuntos relacionados com o cumprimento dos compromissos assumidos pelos Estados-partes nesta Convenção: a) a Comissão Interamericana de Direitos Humanos, doravante denominada a Comissão; e b) a Corte Interamericana de Direitos Humanos, doravante denominada a Corte.” A partir do art. 34 da CADH, há normas sobre organização, funções, competência e processo no âmbito da CIDH. A partir do art. 52, encontram-se esses mesmos elementos - organização, funções, competência e processo - relativos à Corte IDH. 
a um passo de afirmar o caráter de mero conselho ou exortação moral da proteção internacional dos direitos humanos. (grifo meu)

A fim de dar efetividade a esse aparato normativo, por meio de monitoramento e supervisão, foram criados dois órgãos distintos dentro do Sistema: a Comissão Interamericana de Direitos Humanos e a Corte Interamericana de Direitos Humanos.

O documento estabelece a Comissão Interamericana de Direitos Humanos como órgão principal da OEA, com função de promover a observância e a defesa dos direitos humanos e servir como órgão consultivo para a Organização sobre a matéria de direitos humanos. A Comissão Interamericana realiza seu trabalho com base em três pilares: i) o sistema de casos e petições; ii) o monitoramento da situação dos direitos humanos nos Estados membros; e iii) a atenção a linhas temáticas prioritárias ${ }^{121}$.

Outras diretrizes, de forma complementar, também compõem a rotina de trabalho da Comissão. Uma delas expressa-se no princípio pro personae ${ }^{122}$, amplamente difundido no Direito Internacional dos Direitos Humanos. De acordo com este, a interpretação de uma norma deve ser realizada da forma mais favorável ao ser humano. Outra diretriz é fornecida pelo princípio da subsidiariedade ${ }^{123}$, determinando que o Direito Internacional dos Direitos Humanos somente será imperativo caso não exista uma adequada resposta no plano nacional para a violação de direitos humanos. Outra diretriz importante é aquela que diz respeito ao acesso à justiça, a ser tomado como um direito universal. Ainda, a

121 A partir dessa proposta de trabalho, a Comissão considera que, no contexto de proteção dos direitos de toda a pessoa submetida à jurisdição dos Estados americanos, fundamental dar-se atenção às populações, comunidades e grupos historicamente discriminados (CIDH, 2014), tornando, assim, prioritários temas que não encontram espaço para avançar politicamente no âmbito interno dos Estados.

122 Sobre o princípio pro personae, a regra geral é a aplicação da norma internacional - ou mesmo nacional, no caso do controle de convencionalidade - mais favorável à pessoa. Ramos (2013, p. 345) anota o seguinte: “A doutrina em geral aponta que a régle d'or de interpretação das normas de proteção internacional dos direitos humanos é a primazia da norma mais favorável ao indivíduo. Essa busca da maior proteção possível consta explicitamente dos tratados, na medida em que nos mesmos é mencionada a impossibilidade de interpretação do próprio tratado que exclua ou revogue proteção normativa maior já alcançada".

123 Para Cançado Trindade (2003, p. 412), o princípio da subsidiariedade consubstancia-se na seguinte ideia: “(...) é certo que os tribunais internacionais de direitos humanos existentes - as Cortes Europeia e Interamericana de Direitos Humanos - não 'substituem' os tribunais internos, e tampouco operam como tribunais de recursos ou de cassação de decisões dos tribunais internos. Não obstante, os atos internos dos Estados podem a vir a ser objeto de exame por parte dos órgãos de supervisão internacionais quando se trata de verificar a sua conformidade com as obrigações internacionais dos Estados em matéria de direitos humanos. Os atos internos dos Estados não se encontram isentos de verificação quanto ao seu valor de prova, porquanto podem não estar conformes com as obrigações internacionais dos Estados. Isto se aplica à legislação nacional assim como às decisões internas judiciais e administrativas. Por exemplo, uma decisão judicial interna pode dar uma interpretação incorreta de uma norma de um tratado de direitos humanos; ou qualquer outro órgão estatal pode deixar de cumprir uma obrigação internacional do Estado neste domínio. Em tais hipóteses pode-se configurar a responsabilidade internacional do Estado, porquanto seus tribunais ou outros órgãos não são os intérpretes finais de suas obrigações internacionais em matéria de direitos humanos.” 
Comissão trabalha com e pela incorporação da perspectiva de gênero em todas as suas $\operatorname{atividades}^{124}$.

A CIDH mantém as faculdades adicionais conferidas pela Carta da OEA e seus protocolos subsequentes, que antecederam a Convenção e, portanto, não derivam diretamente dela. Entre essas faculdades adicionais da Comissão, estão a de realizar audiências temáticas sobre violações de direitos humanos requeridas por organizações da sociedade civil, assim como Estados, e processar petições individuais relativas a Estados membros da OEA que ainda não são parte da Convenção Americana ${ }^{125}$.

Mas como se chegou a essa complexa estrutura de supervisão e monitoramento de direitos humanos nas Américas? A Comissão Interamericana de Direitos Humanos foi criada em 1959, reunindo-se, pela primeira vez, no ano de 1960. Em 1961, a Comissão começou a realizar suas visitas in loco, a fim de observar a situação geral dos direitos humanos em um país ou, ainda, para investigar uma situação particular. Desde então, a CIDH realizou inúmeras visitas a todos os países membros da OEA. Em 1965, a CIDH foi autorizada expressamente a receber e processar denúncias e petições sobre casos individuais nos quais se alegavam violações a direitos humanos.

Com sede em Washington, D.C., Estados Unidos da América, é composta por sete membros independentes que desempenham suas funções a título pessoal, ou seja, não são representantes dos Estados de sua origem. Constitui-se em um órgão quase-judicial ${ }^{126}$. O

124 Para Soledad García-Muñoz (2001, p. 32-33), muitos esforços internacionais ainda devem ser empreendidos no que tange os direitos das mulheres e as questões de gênero, a fim de que os países incorporem em seus ordenamentos jurídicos e estruturas políticas e sociais parâmetros adequados relativos ao tema: "Los desafios, en la esfera estricta de la protección internacional de los derechos humanos en relación con la mujer, pasan porque la comunidad internacional en su conjunto adopte una real conciencia de género, y trate de ponerse a la altura de los avances normativos y protectores de los derechos de la mujer; de entrada mediante la ratificación universal y sin reservas de los instrumentos y mecanismos de protección existentes. Todos los países del mundo deben aplicar internamente esos compromisos internacionales, y contribuir a la dotación de los recursos necesarios a los órganos internacionales de protección de derechos humanos para que puedan, a cabalidad, desempeñar las funciones que les han sido encomendadas. Tales órganos tienen que mirar con mucha atención hacia la mujer, desarrollar jurisprudencia con contenido de género tan pronto tengan oportunidad, e incorporar la perspectiva de género en su estructura y funcionamiento cotidiano."

125 Os Estados Unidos da América são o exemplo mais contundente de um país que não faz parte da Convenção Americana de Direitos Humanos, assim como não subscreveu qualquer tratado sobre direitos humanos no âmbito regional ou universal, mas que é frequentemente instado a responder questionamentos feitos pela CIDH sobre sua situação de direitos humanos, com base na força normativa da Carta da OEA e da Declaração Americana. O esforço da CIDH é no sentido da universalização dos instrumentos interamericanos. Para maiores informações, cf. o Relatório da CIDH intitulado "Consideraciones sobre la ratificación universal de la Convención Americana y otros tratados interamericanos en materia de derechos humanos", de 14 de agosto de 2014.

126 A Comissão é assim denominada porque possui uma série de características que somente possuem órgãos judiciais; todavia, não se constitui em uma Corte. O Protocolo de Buenos Aires, de 1967, declarou-a como órgão principal da OEA, com a missão de zelar, por meio do prisma jurídico, pela promoção dos direitos humanos, atestando, da mesma forma, o eventual descumprimento das normas de direitos humanos pelos 
mandato de quatro anos dos comissionados caracteriza-se por uma série de tarefas, dentre elas, tornar-se relator ou chefe de unidade temática, que, atualmente, são as seguintes ${ }^{127}: i$ ) Relatoria sobre os Direitos das Mulheres; ii) Relatoria sobre os Direitos dos Migrantes; iii) Relatoria sobre Defensoras e Defensores de Direitos Humanos; iv) Relatoria sobre os Direitos dos Povos Indígenas; v) Relatoria sobre os Direitos das Pessoas Privadas de Liberdade; vi) Relatoria sobre os Direitos das Pessoas Afrodescendentes e contra a Discriminação Racial; vii) Relatoria sobre os Direitos da Criança; viii) Relatoria sobre os Direitos das Pessoas Lésbicas, Gays, Bissexuais, Trans e Intersex (LGBTI); e, ix) Unidade sobre os Direitos Econômicos, Sociais e Culturais. As relatorias encarregam-se de investigar, à distância ou in loco ${ }^{128}$, as violações de direitos humanos relacionadas aos seus respectivos temas e preparam relatórios a esse respeito, dentre outras funções.

O sistema de casos e petições é sua atribuição mais conhecida. Por meio dele, a Comissão constitui-se na porta de entrada para o Sistema Interamericano de Direitos Humanos, e a única maneira ${ }^{129}$ de se chegar à Corte Interamericana de Direitos Humanos. Petições ou denúncias de indivíduos, grupos de indivíduos ou organizações da sociedade civil que denunciam violações de direitos humanos, ocorridas em países membros da OEA, consubstanciadas em violações ao texto da $\mathrm{CADH}$, são processadas no âmbito da Comissão.

Estados. Ainda, “A Comissão é o órgão ao qual incumbe a promoção e averiguação do respeito e a garantia destes direitos fundamentais. Pode elaborar estudos e ofertar capacitação técnica aos Estados. Pode também criar relatorias (similares às relatorias do mecanismo extraconvencional onusiano), dirigidas pelos Comissários, cujos relatórios serão submetidos à Assembleia Geral da OEA. Além disso, pode efetuar visitar de campo, a convite do Estado interessado.” (RAMOS, 2013, p. 209-211)

127 A Relatoria Especial para a Liberdade de Expressão foi criada pela CIDH em outubro de 1997, durante o seu $97^{\circ}$ Período de Sessões. Foi estabelecida como um escritório permanente e independente, atuando dentro do marco e com o apoio da CIDH. Em seu $98^{\circ}$ Período de Sessões, celebrado em março de 1998, a CIDH definiu de modo geral as características e funções da Relatoria Especial, e decidiu criar um fundo voluntário para a sua assistência econômica. A pessoa que exerce a função de relatora ou relator não é um comissionado, daí seu caráter independente. É a única relatoria que se estrutura dessa forma.

128 Devido aos recorrentes cortes orçamentários, a CIDH tem realizado, nos últimos anos, cada vez menos inspeções e visitas in loco. Em 2015, a fỉm de dar tratamento à grave situação de desaparecimento de 43 estudantes em Ayotzinapa no México, a Comissão, de forma muito criativa, delegou as competências de relatoria para uma comissão de experts que têm realizando o trabalho de coleta de dados e confecção de relatórios, acompanhando o caso de perto e reportando os resultados à CIDH. Essa experiência aponta para uma alternativa às inspeções e visitas, já que se resolvem os problemas orçamentários para deslocamento e manutenção de equipes da CIDH no México e, ao mesmo tempo, constroem-se localmente redes de proteção e promoção de direitos humanos em torno do caso, com a chancela da Comissão Interamericana de Direitos Humanos. Informações sobre o Grupo Interdisciplinario de Expertos Independientes (GIEI) disponíveis em $<$ www.oas.org/es/cidh/actividades/giei.asp $>$, acesso em outubro de 2015.

129 A princípio, o sistema de casos e petições é iniciado na CIDH. Contudo, existem exceções, formas de se escapar dessa necessária porta de entrada da Corte por meio da Comissão: a) as medidas de urgência na Corte denominadas medidas provisórias -, a depender do caso em concreto, poderão ser analisadas e concedidas expressamente pela Corte, sem terem de passar pela Comissão; b) as opiniões consultivas, que são interpretações que a Corte faz sobre a Convenção, a partir da iniciativa de um Estado ou grupos de Estados; e c) os casos de demanda entre Estados - modalidade que até a presente data não ocorreu. 
Somente após o trâmite perante a CIDH, um caso de violação de direitos humanos aporta na Corte Interamericana de Direitos Humanos.

Ressalta-se que as petições ou denúncias podem ser enviadas por correio postal, fac-símile ou mesmo correio eletrônico, desde que preenchido o formulário de denúncia, conforme se encontra no sítio na internet ${ }^{130}$. Essa petição ou denúncia não precisa ser assinada por advogado; pode ser subscrita pela vítima ou por quem a representar ${ }^{131}$. Essa informalidade, característica do Sistema Interamericano, representa a ampliação da possibilidade de denúncias de violações de direitos humanos chegarem à CIDH e poderem ter um encaminhamento no sentido de prevenir e proteger as vítimas que sofrem com graves violações.

Ao receber uma petição ou denúncia, a CIDH realiza exame prévio e, assim, inicia-se o processo de admissibilidade ${ }^{132}$. A partir do processamento da petição ou denúncia, a CIDH informa ao Estado o seu recebimento e pede informações a seu respeito. Aqui, a depender do tema, caminho escolhido ou objeto da petição ou denúncia, o tempo de demora pode variar de maneira considerável ${ }^{133}$. Enviadas comunicações da Comissão tanto para o

130 Em folheto, a CIDH explica, de forma bastante didática, como funciona a formulação de uma denúncia, disponível <www.oas.org/es/cidh/docs/folleto/CIDHFolleto_port.pdf $>$, acesso em junho de 2015. A princípio, as denúncias podem ser feitas por e-mail, no site da CIDH, por correio e por fac-símile. Ainda, em 2015, foi lançado um sistema de peticionamento on-line, que se pretende, para o futuro, tornar-se o sistema em que se encontrarão as informações de todas as petições e casos em trâmite na CIDH. Sobre esse novo sistema, o Portal del Sistema Individual de Peticiones está disponível em $<$ www.oas.org/es/cidh/portal/>, acesso em outubro de 2015.

131 A CADH dispõe, em seu art. 44 que "Qualquer pessoa ou grupo de pessoas, ou entidade nãogovernamental legalmente reconhecida em um ou mais Estados-membros da Organização, pode apresentar à Comissão petições que contenham denúncias ou queixas de violação desta Convenção por um Estado-parte".

$132 \mathrm{O}$ art. 46 da $\mathrm{CADH}$ prevê os requisitos de admissibilidade de uma petição: "Para que uma petição ou comunicação apresentada de acordo com os artigos 44 ou 45 seja admitida pela Comissão, será necessário: a) que hajam sido interpostos e esgotados os recursos da jurisdição interna, de acordo com os princípios de Direito Internacional geralmente reconhecidos; b) que seja apresentada dentro do prazo de seis meses, a partir da data em que o presumido prejudicado em seus direitos tenha sido notificado da decisão definitiva; c) que a matéria da petição ou comunicação não esteja pendente de outro processo de solução internacional; e d) que, no caso do artigo 44, a petição contenha o nome, a nacionalidade, a profissão, o domicílio e a assinatura da pessoa ou pessoas ou do representante legal da entidade que submeter a petição. 2. As disposições das alíneas 'a' e 'b' do inciso 1 deste artigo não se aplicarão quando: a) não existir, na legislação interna do Estado de que se tratar, o devido processo legal para a proteção do direito ou direitos que se alegue tenham sido violados; b) não se houver permitido ao presumido prejudicado em seus direitos o acesso aos recursos da jurisdição interna, ou houver sido ele impedido de esgotá-los; e c) houver demora injustificada na decisão sobre os mencionados recursos."

133 Para se ter uma ideia, os casos contra o Estado brasileiro, quanto aos temas, possuem espectro amplo: desde debates jurídicos sobre regime de precatórios e duração razoável do processo - em sede de petição, assinada por advogado, referente a processo específico de um indivíduo da cidade de São Paulo - a denúncias sobre genocídio de povos indígenas guarani-kaiowás - em sede de medida cautelar, com representação assinada por uma série de organizações da sociedade civil, com fotos, vídeos e depoimentos sobre ataques, referente a um processo social amplo de desmonte da proteção social e regime jurídico constitucional indígena, tendo como vítimas povos do interior do Mato Grosso do Sul. O ponto que se procura comprovar é que os casos no âmbito do Sistema Interamericano são muito diferentes entre si, possuindo tratamento diferenciado 
Estado, quanto para a parte peticionária, estabelece-se, assim, o contraditório, ficando conhecidos os pontos de vista de ambas as partes - Estado e peticionários. A CIDH tem condições, após determinado tempo e a depender da complexidade e urgência do caso, de adotar a decisão sobre a admissibilidade da petição.

Os requisitos para admissibilidade ${ }^{134}$ da petição são os seguintes: i) que tenham sido interpostos e esgotados os recursos internos para resolução da questão ${ }^{135}$; ii) que a petição tenha sido apresentada dentro do prazo de seis meses seguintes à notificação de uma decisão definitiva no plano interno ${ }^{136}$; e, iii) que a matéria da petição não esteja pendente de resultado em outro procedimento internacional, o que se denomina litispendência internacional $^{137}$.

A Comissão Interamericana de Direitos Humanos emite um relatório em que descreve brevemente o posicionamento de ambas as partes, trazendo também sua posição sobre os direitos da $\mathrm{CADH}$ presumidamente violados. Uma vez adotada a decisão sobre a admissibilidade da petição, emite-se o chamado relatório de admissibilidade, em que ficam

pela Comissão, assim como produzindo resultados muito diversos.

134 Cançado Trindade (2003, p. 41-2) explica como funciona na prática o exame de admissibilidade de petições pela CIDH: “A prática da Comissão Interamericana a respeito, mesmo antes da adoção e entrada em vigor da Convenção Americana sobre Direitos Humanos, tem demonstrado que aquele requisito de admissibilidade não é sacrossanto, imutável ou absoluto, e tem sido aplicado - à luz do critério da eficácia dos recursos internos - com muito mais flexibilidade no contexto da proteção internacional dos direitos humanos. Aqui os recursos internos formam parte integrante do próprio sistema de proteção internacional dos direitos humanos, em ênfase no elemento da reparação (redress) e não no processo de um esgotamento mecânico de recurso. Tal requisito dá testemunho da interação entre o direito internacional e o direito interno no presente contexto de proteção, fundamentalmente orientado às vítimas aos direitos dos seres humanos e não dos Estados. As regras geralmente reconhecidas do direito internacional - as quais se refere a formulação do requisito do esgotamento nos tratados e instrumentos internacionais de proteção dos direitos humanos, ademais de seguirem uma evolução própria nos distintos contextos em que se aplicam, sofrem necessariamente, quando inseridas em tratados e instrumentos de direitos humanos, um certo grau de ajuste ou adaptação, ditado pelo caráter especial do objeto e propósito destes e pela especificidade amplamente reconhecida da proteção internacional dos direitos humanos."

135 Há exceções a esse requisito na Opinião Consultiva n. 11 de 1990 da Corte Interamericana de Direitos Humanos, que trata do acesso ao Sistema Interamericano por pessoas indigentes ou sem recursos para acessar a justiça doméstica. A opinião consultiva é instrumento de interpretação da CADH, previsto em seu art. 64: "1. Os Estados-membros da Organização poderão consultar a Corte sobre a interpretação desta Convenção ou de outros tratados concernentes à proteção dos direitos humanos nos Estados americanos. Também poderão consultá-la, no que lhes compete, os órgãos enumerados no capítulo X da Carta da Organização dos Estados Americanos, reformada pelo Protocolo de Buenos Aires. 2. A Corte, a pedido de um Estado-membro da Organização, poderá emitir pareceres sobre a compatibilidade entre qualquer de suas leis internas e os mencionados instrumentos internacionais." (grifo meu)

136 As exceções previstas na Opinião Consultiva n. 11 de 1990 da Corte IDH também se aplicam, em parte, a esse requisito.

137 Sobre a litispendência internacional, muito interessante anotar-se que, em face da multiplicidade de níveis de proteção e diversidade de mecanismo que existem para investigação e responsabilização em termos de direitos humanos, esse conceito - que tem origem no direito internacional público clássico, em que os únicos personagens possíveis eram os Estados - vem sendo mitigado, muito em função dos desafios práticos impostos ao direito internacional dos direitos humanos. 
registrados os fatos - consubstanciadores da violação de direitos humanos - e os artigos infringidos da Convenção Americana. Inicia-se, daí, o procedimento sobre o mérito. Nesta fase, a Comissão pode, por exemplo, colocar-se à disposição das partes para composição de uma solução amistosa ${ }^{138}$; pode, ainda, pedir esclarecimentos específicos sobre algum fato que chegou a seu conhecimento ou mesmo convocar as partes para uma reunião de trabalho.

Não se chegando a uma solução amistosa, a Comissão emite um relatório de mérito, em que considera, ponderando a partir de todos os fatos que chegaram a seu conhecimento, dentro do seu quadro normativo, se o Estado denunciado violou ou não direito reconhecido em um instrumento interamericano. Constatada tal violação, a CIDH emite recomendações com a finalidade de reparação de danos, tanto do ponto de vista de quem teve seus direitos violados, quanto no sentido da prevenção de novas violações de direitos humanos, por conta do caráter estrutural da violação em tela. Não havendo o cumprimento espontâneo do Estado, o caso pode ser apresentado pela Comissão à Corte IDH. Esse procedimento que acabou de ser descrito em linhas gerais é o padrão, qual seja, o processamento de uma petição. Quando a violação de direitos humanos envolver matéria de urgência e gravidade, as medidas cautelares ${ }^{139}$ poderão ser utilizadas, a fim de que sejam resguardados esses direitos, configurada a situação de urgência e gravidade.

A Corte Interamericana de Direitos Humanos constitui-se na instituição judicial da Organização dos Estados Americanos. Compõe-se de sete juízes e tem sede em San José da Costa Rica. Possui várias competências, entre as quais emitir opiniões consultivas sobre matéria de Direito Internacional de Direitos Humanos, decretar medidas provisórias em casos de gravidade extrema e urgência para evitar danos irreparáveis a pessoas. Contudo, sua função contenciosa é a mais conhecida e reconhecida.

138 A solução amistosa tem sido cada vez mais incentivada pela Comissão Interamericana de Direitos Humanos. Significa que, na prática, as partes - Estado e vítimas/peticionários - são instigadas pela Comissão a negociarem uma solução para as violações de direitos humanos. O Brasil, infelizmente, possui apenas dois casos de solução amistosa: a) Relatório de solução amistosa n. 95/03, de 24 de outubro de 2003, relativo ao caso 12. 289 - José Pereira versus Estado brasileiro, que se refere ao tema do trabalho escravo; b) Relatório de solução amistosa n. 43/06, de 15 de março de 2006, relativo aos casos 12.426 e 12.427 - Meninos emasculados do Maranhão, que se refere a mutilação e assassinato de adolescentes, em que houve falha graves dos órgãos locais do Sistema de Justiça. Para informações sobre o estado da arte da solução amistosa na CIDH, cf. o Relatório da CIDH intitulado "Impacto del procedimiento de solución amistosa", de 18 de dezembro de 2013. 139 Medidas cautelares são as medidas de urgência previstas no âmbito da Comissão Interamericana; medidas provisórias são as medidas de urgência previstas no âmbito da Corte Interamericana de Direitos Humanos. Até em função da matéria - proteção do direito à vida, art. $4^{\circ}$ da $\mathrm{CADH}$, e proteção da integridade pessoal, art. $5^{\circ}$ da $\mathrm{CADH}$-, os casos sobre o sistema prisional brasileiro chegam à CIDH pela via das medidas cautelares. Explorar-se-á esse ponto quando da atenção ao caso concreto do Presídio Professor Aníbal Bruno, que aportou, primeiramente, na CIDH como pedido de medidas cautelares e agora encontra-se na Corte, com a decretação de medidas provisórias. 
Para que um Estado possa ser acionado perante a Corte IDH, devem ser cumpridos os seguintes requisitos indispensáveis: a) $\mathrm{O}$ Estado deve ter ratificado a Convenção Americana sobre Direitos Humanos; e, b) O Estado deve ter declarado expressamente que aceita a competência contenciosa da Corte ${ }^{140}$. Uma vez que um caso é submetido pela Comissão Interamericana de Direitos Humanos à Corte IDH, existe um procedimento escrito e oral, com audiências, perícias, testemunhos, oitivas de vítimas, similar a qualquer outro procedimento contencioso doméstico. Por conta da reforma do Regulamento da Corte, que entrou em vigor em $1^{\circ}$ de janeiro de 2010 , foram modificados alguns aspectos envolvendo a participação da CIDH no procedimento de um caso contencioso. Como resultado dessa mudança, pode-se dizer que, atualmente, o protagonismo no litígio perante a Corte IDH é exercido pelas vítimas e pelos representantes das vítimas.

Em suas sentenças condenatórias, a Corte normalmente ordena o Estado a pagar uma compensação às vítimas, além de arcar com as custas processuais, assim como a executar outras formas de reparação, tais como medidas de não-repetição de violações de direitos humanos, como atos públicos de reconhecimento de responsabilidade, pedido de desculpas públicas às vítimas, modificações legislativas ou constitucionais, entre outras medidas. As sentenças da Corte Interamericana possuem caráter “definitivo e inapelável”, sendo seu cumprimento obrigatório, de acordo com a Convenção Americana. Os Estados devem, portanto, cumprir a ordem da Corte, mesmo que de forma parcial. Caso não haja o cumprimento, há previsão no artigo 65 da $\mathrm{CADH}^{141}$ da faculdade de informar tal descumprimento à Assembleia Geral da OEA.

Até aqui foi tratada a questão da estrutura do SIDH. Em seguida, passa-se ao debate sobre o conteúdo produzido pela Corte Interamericana de Direitos Humanos. A jurisprudência interamericana constitui-se em acervo fundamental para o trabalho das

140 Dos 23 Estados que atualmente ratificam a Convenção Americana, 21 (vinte e um) reconheceram, adicionalmente, a competência contenciosa da Corte IDH: Argentina, Barbados, Bolívia, Brasil, Chile, Colômbia, Costa Rica, Equador, El Salvador, Guatemala, Haiti, Honduras, México, Nicarágua, Panamá, Paraguai, Peru, República Dominicana, Suriname, Uruguai e Venezuela. Nesse sentido, ressalta-se a situação da Venezuela. O país ratificou a CADH em 09 de agosto de 1977 e reconheceu a competência contenciosa da Corte IDH em 24 de junho de 1982. Em 10 de setembro de 2012, a Venezuela denunciou a Convenção com base em seu artigo 78. A denúncia somente surte efeitos, de acordo com o texto convencional, um ano depois de sua subscrição. Portanto, as violações aos direitos humanos que ocorreram após o dia 10 de setembro de 2013 não podem ser conhecidas pela Corte. Em função disso, apenas os primeiros 20 (vinte) Estados antes mencionados podem ser demandados perante o órgão a menos que, no caso específico da Venezuela, os fatos tenham ocorrido antes da data de entrada em vigor dos efeitos da denúncia.

$141 \mathrm{O}$ art. 65 da CADH dispõe o seguinte: "A Corte submeterá à consideração da Assembleia Geral da Organização, em cada período ordinário de sessões, um relatório sobre as suas atividades no ano anterior. De maneira especial, e com as recomendações pertinentes, indicará os casos em que um Estado não tenha dado cumprimento a suas sentenças." 
autoridades nacionais, no sentido da proteção aos direitos humanos em consonância com os instrumentos normativos internacionais. Os chamados parâmetros interpretativos interamericanos, extraídos dos julgados da Corte garantem uma efetividade mínima à Convenção Americana, a partir da ampliação dos efeitos para o âmbito interno dos países (MAC-GREGOR, 2014, p. 116).

Em termos de direito penal, que possui relação com a presente pesquisa, pode-se encontrar abundante jurisprudência da Corte ${ }^{142}$. Julgados que, em última análise, constituemse em desdobramentos dos dispositivos da normativa interamericana, aplicados a casos concretos. Na análise de Eduardo Mac-Gregor Poisot (2014, p. 30-31), há sete linhas jurisprudenciais em matéria de justiça penal na Corte Interamericana de Direitos Humanos $^{143}$, quais sejam tortura e outros tratamentos ou penas cruéis, desumanos ou degradantes, execução extrajudicial, desaparecimento forçado de pessoas, jurisdição militar, leis de anistia, responsabilidades ulteriores no exercício da liberdade de expressão e pena de morte.

Nesse sentido, cumpre destacar entendimento da Corte, a partir do Caso Gelman contra Uruguai, em sede de Supervisão de Cumprimento de Sentença (2013). Determinouse, ali, que há obrigação para todos os Estados, mesmo não sendo parte no processo internacional em que foi estabelecido o julgado específico, mas apenas por serem parte da Convenção, no sentido de que todas suas autoridades públicas e todos seus órgãos estão

142 Mac-Gregor (2014, p. 29) aponta a importância da área penal para a formação da jurisprudência da Corte, o que também, ao mesmo tempo, aponta a necessidade que as vítimas e as organizações possuem ao demandarem o Sistema Interamericano de Direitos Humanos, ou, por outro lado ainda, a área do direito que constitui o foco de violação pelos Estados: "La jurisprudencia de la Corte Interamericana de Derechos Humanos (Corte IDH o Tribunal Interamericano) en materia de justicia penal es tan rica como abundante, si tenemos en consideración que de los 172 casos contenciosos que ha resuelto hasta finales de enero de 2014 , aproximadamente 140 se refieren a esta materia1. Lo anterior implica que un $\mathbf{8 1 \%}$ del total de casos contenciosos están directamente relacionados con la materia penal o procesal penal." (grifo meu)

$143 \mathrm{O}$ autor continua, buscando indicadores mais específicos, para avaliar quais são os direitos mais violados dentre as denúncias que chegam à Corte IDH: "Para efectos de estudio y sistematización, podemos agrupar estos 140 casos relacionados con la justicia penal en siete grandes líneas jurisprudenciales, que el Tribunal Interamericano ha venido desarrollando a lo largo de sus más de veinticinco años de jurisdicción contenciosa, desde la primera sentencia de fondo que dictó en el emblemático caso Velásquez Rodríguez v. Honduras, de 1982. Estas siete principales líneas jurisprudenciales (mencionando el número de casos y porcentaje que la integran del total de asuntos en justicia penal) son: (1) tortura y otros tratos o penas crueles, inhumanos o degradantes ( 89 casos, 51\%); (2) ejecución extrajudicial (42 casos, 24\%); (3) desaparición forzada de personas (35 casos, 20\%); (4) jurisdicción militar (19 casos, 11\%); (5) leyes de amnistía (14 casos, 8\%); (6) responsabilidades ulteriores en el ejercicio de la libertad de expresión ( 8 casos, 4\%), y (7) pena de muerte ( 5 casos, 2\%). Cabe aclarar que hemos destacado las siete principales líneas jurisprudenciales atendiendo el número reiterado de casos que ha conocido el Tribunal Interamericano y al impacto que han tenido en el ámbito interno de los Estados. Existen, evidentemente, diversos temas no contemplados en estas líneas jurisprudenciales de gran trascendencia para la justicia penal, por ejemplo, los relativos al principio de legalidad y de no retroactividad, presunción de inocencia, adecuada defensa, doble instancia, ne bis in idem, entre otros (18 casos, 10\% del total de casos en materia de justicia penal)" (MAC-GREGOR, 2014, p. 29-30). 
vinculados ao parâmetro estabelecido pelos precedentes da jurisprudência da Corte Interamericana $^{144}$.

O que se pretende apontar é que, apesar do Estado brasileiro possuir quatro condenações na Corte Interamericana de Direitos Humanos ${ }^{145}$, inexistindo marco normativo interno para a execução ${ }^{146}$ das próximas sentenças condenatórias que serão inevitavelmente emitidas contra o Estado brasileiro ${ }^{147}$, faz-se, aqui, uma nova proposta: ao invés de se pensar nos casos específicos, que deverão passar por todo o trâmite, tanto na Comissão Interamericana de Direitos Humanos, quanto na Corte IDH, até chegarem a uma sentença, que depois também terá de ser cumprida - com todas as dificuldades que existem, mesmo nos países em que o cumprimento tem maior efetividade, como a Argentina e a Colômbia por que não se pensar nos casos já julgados pela Corte Interamericana e a interpretação que deles podem ser extraídas no sentido de concretizar o entendimento da Convenção Americana de Direitos Humanos no plano jurídico interno dos países? A proposta é, portanto, a mudança do foco de atenção para o tema: por meio da observância, por todos os

144 De acordo com Resolução da Corte IDH, de 20 de março de 2013, em sede de Supervisão de Cumprimento de Sentença, § 69: "En cambio, diversa eficacia de vinculación produce la sentencia interamericana para los demás Estados Parte que no intervinieron en el proceso internacional, al sólo limitarse a la "jurisprudencia interamericana", es decir, a la "norma convencional interpretada" y no así a la totalidad del fallo. Esta eficacia interpretativa es "relativa", en la medida en que se produce siempre y cuando no exista una interpretación que otorgue mayor efectividad a la norma convencional en el ámbito nacional. Esto es así, ya que las autoridades nacionales pueden ampliar el estándar interpretativo; incluso, pueden dejar de aplicar la norma convencional cuando exista otra norma nacional o internacional que amplíe la efectividad del derecho o libertad en juego, en términos del artículo 29 de la Convención Americana. Además, deben considerarse las reservas, declaraciones interpretativas y denuncias en cada caso, si bien en esos supuestos la Corte IDH puede, eventualmente, pronunciarse sobre su validez y adecuada interpretación, 1 como lo ha realizado en algunas ocasiones". Esse pronunciamento da Corte Interamericana de Direitos Humanos expandiu o conceito de controle de convencionalidade, tema que ainda não encontrou espaço na prática e no debate jurídico no Brasil. 145 Das quatro sentenças de condenação contra o Estado brasileiro - Damião Ximenes Lopes (2006), Sétimo Garibaldi (2009), Escher (2009) e Guerrilha do Araguaia (2010) -, apenas a sentença do caso Escher está completamente cumprida, de acordo com Resolução da Corte IDH de 19 de junho de $2012 \mathrm{em}$ sede de Supervisão de Cumprimento de Sentença no caso, que resolve: "1. Dar por concluído o caso Escher e outros, em razão de que o Estado do Brasil deu cumprimento ao que fora ordenado nos pontos resolutivos sétimo, oitavo e décimo da Sentença emitida pela Corte Interamericana de Direitos Humanos em 9 de julho de 2009 e da conclusão da supervisão do cumprimento do ponto resolutivo nono da referida Sentença. 2. Arquivar o expediente do presente caso". As outras sentenças de condenação do Estado brasileiro ainda estão em fase de supervisão.

146 Não existe, no Brasil, a chamada lei ponte, que faz a ligação entre os planos interno e internacional. Existem alguns projetos de lei, mas nenhum, até o presente momento, dá conta da diversidade de situações que são impostas pelos dispositivos de sentenças da Corte Interamericana de Direitos Humanos. Dentre os casos atuais, sem dúvida o de maior dificuldade para cumprimento é a sentença da Guerrilha do Araguaia. A fim de que fique bem esclarecido, aqui, não se está afirmando que a inexistência da chamada lei ponte seja algo desejável. Apenas propõe-se um outro enfoque.

147 Em 2015, dois casos brasileiros que há muito estavam em trâmite na Comissão Interamericana de Direitos Humanos foram apresentados à Corte Interamericana: Fazenda Brasil Verde (Caso n. 12.066) - referente a violações de direitos humanos envolvendo trabalho escravo no Pará - e Favela Nova Brasília (Caso n. 11.566) - referente a violência policial e execução extrajudicial no Rio de Janeiro. 
agentes públicos, dos parâmetros interpretativos interamericanos, decorrentes da rica jurisprudência da Corte Interamericana de Direitos Humanos.

\subsubsection{O Estado brasileiro perante o Sistema Interamericano de Direitos Humanos}

O primeiro ponto que deve ser tratado, ao se estudar o direito internacional dos direitos humanos no Brasil desde a perspectiva estatal, é o enfrentamento crítico do debate sobre a hierarquia das normas nacionais e internacionais - mais especificamente as internacionais de direitos humanos -, o qual pode ser chamado, ainda, no país, de debate da supremacia da norma nacional sobre a internacional. Esse tema é importante porque, para além de determinar como se concretiza o direito internacional dos direitos humanos no plano nacional, indica, pelo seu estado atual, que o país possui uma cultura jurídica fechada e provinciana, que não admite que norma internacional tenha força vinculante maior que aquelas emanadas pelo seu poder constituinte originário. A decorrência lógica - e ponto mais relevante para quem decide, em última análise, sobre o assunto - é que as decisões do Supremo Tribunal Federal sobre a constitucionalidade das normas são absolutamente intangíveis pelo direito internacional dos direitos humanos.

Em dezembro de 2008, sobreveio a tese da supralegalidade das normas de tratados internacionais de direitos humanos. O Supremo Tribunal Federal, em sede do Recurso Extraordinário n. 466.343, entendeu insubsistente a disposição constitucional e a correlata legislação infraconstitucional que determinava a prisão civil do depositário infiel, compreendendo-a como afronta ao $\S 7^{\circ}$ do artigo $7^{\circ}$ da Convenção Interamericana de Direitos Humanos, dispositivo que veda a prisão civil para tais casos. A maioria dos ministros decidiu pela modificação da jurisprudência anterior daquela Corte, que, até então, entendia que as Convenções e Tratados Internacionais, inclusive de Direitos Humanos, adentravam no sistema jurídico nacional com o status de lei ordinária. $\mathrm{O}$ voto condutor da posição vencedora, do Ministro Gilmar Mendes, teve por fundamento, dentre outros ${ }^{148}$, o novo parágrafo $3^{\circ}$ do artigo $5^{\circ}$ da Constituição Federal de $1988^{149}$, introduzido pela Emenda Constitucional n. 45 de 2004. Para o Ministro, com base nesse dispositivo constitucional, os

$148 \mathrm{O} \S 2^{\circ}$ do artigo $5^{\circ}$ da Constituição Federal de 1988 dispõe o seguinte: "Os direitos e garantias expressos nesta Constituição não excluem outros decorrentes do regime e dos princípios por ela adotados, ou dos tratados internacionais em que a República Federativa do Brasil seja parte.”

$149 \mathrm{O} \S 3^{\circ}$ do artigo $5^{\circ}$ da Constituição Federal de 1988 dispõe o que se segue: "Os tratados e convenções internacionais sobre direitos humanos que forem aprovados, em cada Casa do Congresso Nacional, em dois turnos, por três quintos dos votos dos respectivos membros, serão equivalentes às emendas constitucionais." 
tratados e convenções sobre direitos humanos que não forem internalizados sob o rito qualificado exigido pelo novo parágrafo são infraconstitucionais, entretanto, supralegais. Segundo o STF, portanto, os tratados internacionais de direitos humanos - inclusive a própria $\mathrm{CADH}$ - que não forem aprovados segundo a nova regra do $\S 3^{\circ}$, art. $5^{\circ}$, da Constituição ${ }^{150}$, são hierarquicamente inferiores à Constituição, mas, pela natureza da matéria, sempre superiores à legislação infraconstitucional, inclusive leis complementares.

Na sequência, em 29 de abril de 2010, o Supremo Tribunal Federal julgou a ADPF 153, em que, por maioria, rejeitou pedido da OAB para a revisão da Lei n. 6.683 de $1979^{151}$ - a Lei de Anistia. O relator do processo, Ministro Eros Grau ressaltou não caber ao Poder Judiciário rever acordo político que, na transição do regime militar para a democracia, resultou na anistia daqueles que cometeram crimes políticos e conexos a eles no Brasil, colocando-se firmemente no sentido da impossibilidade da revisão da lei.

Meses depois, em 24 de novembro de 2010, a Corte Interamericana de Direitos Humanos finalizou um longo processo no SIDH, condenando o Estado brasileiro no caso Gomes Lund (Guerrilha do Araguaia); dentre seus vários dispositivos, a Corte Interamericana determinou que a Lei de Anistia é incompatível com a Convenção Americana e que, portanto, não produz efeitos jurídicos ${ }^{152}$. Segundo a Corte IDH,

(...) em prol da garantia da supremacia dos Direitos Humanos, especialmente quando degradados por crimes de lesa-humanidade, faz-se mister reconhecer a importância dessa sentença internacional e incorporá-la de imediato ao ordenamento nacional, de modo a que se possa investigar, processar e punir aqueles crimes até então protegidos por uma interpretação da Lei de Anistia que, afinal, é geradora de impunidade, descrença na proteção do Estado e de uma ferida social eternamente aberta, que precisa ser curada com a aplicação serena mas incisiva do Direito e da Justiça. (grifo meu)

$150 \mathrm{O}$ único texto convencional que passou pelo referido trâmite foi a Convenção Internacional sobre os Direitos das Pessoas com Deficiência das Nações Unidas, conhecida como Convenção de Nova Iorque, de 30 de março de 2007. Em função do atual entendimento do STF, pode-se afirmar que a Convenção de Nova Iorque possui maior força normativa que a Convenção Americana de Direitos Humanos.

151 A Lei de Anistia é a Lei Federal n. 6.683/79, que dispõe sobre a concessão de anistia a todos que, no período compreendido entre 02 de setembro de 1961 e 15 de agosto de 1979, cometeram crimes políticos ou conexo com estes.

152 Excerto da sentença segue nesse sentido: "As disposições da Lei de Anistia brasileira que impedem a investigação e sanção de graves violações de direitos humanos são incompatíveis com a Convenção Americana, carecem de efeitos jurídicos e não podem seguir representando um obstáculo para a investigação dos fatos do presente caso, nem para a identificação e punição dos responsáveis, e tampouco podem ter igual ou semelhante impacto a respeito de outros casos de graves violações de direitos humanos consagrados na Convenção Americana ocorridos no Brasil." (grifo meu) 
Deve-se apontar que, partindo-se da ideia acima esboçada de aplicação de parâmetros interpretativos interamericanos, o Supremo Tribunal Federal poderia ter se apoiado no extenso cabedal de jurisprudência sobre leis de anistia da Corte IDH $^{153}$ para responder juridicamente de forma oposta ao que fez na ADPF 153.

Aqui, ressalta-se: a interpretação nacional de norma internacional não é válida; para buscar o direito interpretado, deve-se ir até aquele que é legitimado para fazer essa interpretação. Ao buscar uma interpretação da Convenção Americana de Direitos Humanos, deve-se ir até a Corte Interamericana de Direitos Humanos, e não ao Supremo Tribunal Federal. Nesse sentido há total concordância com o que se afirma Ramos (2013) quando aponta a ausência de diálogo entre a jurisprudência nacional com a internacional:

Com efeito, após a adesão brasileira a mecanismos internacionais de
averiguação de respeito a normas de direitos humanos, cabe agora
compatibilizar a jurisprudência do STF sobre os diversos direitos
protegidos com a posição hermenêutica dos citados órgãos internacionais.
Pior, continuar nesse caminho de ausência de diálogo, a
internacionalização dos direitos humanos para o STF parece ser restrita aos
textos dos tratados: a interpretação deles deve continuar a ser nacional.
Esse caminho 'nacionalista' nega a universalidade dos direitos
humanos e transforma os tratados e a Declaração Universal de
Direitos Humanos em peças de retórica, pois permite que cada país
interprete o que é 'tortura', 'intimidade', 'devido processo legal' e
outros comandos abertos dos textos de direitos humanos, gerando
riscos de abuso e relativismo puro e simples. (RAMOS, 2013, p. 374)
(grifo meu)

Mais adiante, quando da análise da situação do caso Aníbal Bruno, o argumento de que o caso ainda não tramitou por todo o procedimento junto ao Sistema Interamericano de Direitos Humanos, produzindo sentença de condenação contra o Estado brasileiro, é débil. Existe vasta jurisprudência, inúmeros precedentes, que vinculam, sim, o Estado brasileiro, pois se constituem em parâmetros interpretativos interamericanos, orientadores dos Estados signatários da Convenção Americana de Direitos Humanos quanto à proteção das pessoas no âmbito da Organização dos Estados Americanos.

153 A jurisprudência da Corte IDH é farta em matéria de leis de anistia. Barrios Altos versus Perú, de 2001, foi o primeiro caso a enfrentar a questão no continente. Depois dele, vieram, no mesmo sentido, Myrna Mack Chang versus Guatemala, em 2003; Carpio Nicolle e outros versus Guatemala, em 2004; Comunidade Moiwana versus Suriname, em 2005; La Cantuta versus Peru, em 2006; e o caso Almonacid Arellano e outros versus Chile, em 2006. Após o caso Guerrilha do Araguaia, ainda houve a condenção de dois Estados em casos dessa natureza: Gelman versus Uruguay, em 2011 - em que a Corte avança ainda mais em sua compreensão sobre as leis de anistia e, também, sobre o controle de convencionalidade - e, mais recentemente, o caso El Mozote versus El Salvador, em 2013. 
O Sistema Interamericano de Direitos Humanos funciona com a finalidade de promover e defender os direitos humanos daquelas e daqueles que se encontram sob sua proteção - a partir dos parâmetros estabelecidos pelos documentos normativos assinados pelos Estados-membros da OEA -, com base na entrega voluntária de parte de sua soberania para a organização interestatal, por meio da ideia de responsabilização internacional dos Estados. Em decorrência disso, não existem indivíduos processados no Sistema Interamericano: encontram-se, em juízo, como "réus", os Estados, e não seus agentes.

Em direitos humanos, esse mecanismo é fundamental: se não existisse a responsabilidade internacional do Estado, em função da subscrição de tratados internacionais, não haveria a possibilidade de dar concretude à normativa internacional de direitos humanos (RAMOS, 2013, p. 32). Se assim não fosse, as normas de proteção teriam apenas função de coagir moralmente os $\operatorname{Estados}^{154}$.

Amplamente aceita pelos teóricos e também pelos juízes das Cortes internacionais e estrangeiras, a força vinculante do direito internacional dos direitos humanos encontra barreiras para ser integralmente admitida pelas instituições que compõem o Estado brasileiro. Enfrenta-se uma série de dificuldades no sentido de dar consequência aos desdobramentos ${ }^{155}$ dessa responsabilidade internacional que se impõe.

Para o direito internacional, os atos internos de um país, suas leis, atos administrativos e decisões judiciais, são expressões da vontade do Estado Democrático de Direito, que tem como sua base o texto constitucional. Além dessa base, tal Estado possui compromissos internacionais, que devem ser observados, sob pena de sua responsabilização internacional. Em consequência, "um Estado não poderá justificar o descumprimento de uma obrigação internacional em virtude de mandamento interno" (RAMOS, 2013, p. 371), mesmo que tal descumprimento esteja baseado em uma norma constitucional:

Assim, mesmo a norma constitucional de um Estado é vista não como 'norma suprema', mas como mero fato, que, caso venha a violar norma jurídica internacional, acarretará a responsabilização internacional do

154 Ramos (2013, p. 32) esclarece a função da responsabilidade internacional do Estado: "No campo dos direitos humanos, a responsabilização do Estado é essencial para reafirmar a juridicidade deste conjunto de normas voltado para a proteção dos indivíduos e para a afirmação da dignidade humana. Com efeito, as obrigações internacionais nascidas com a adesão dos Estados aos instrumentos internacionais de proteção aos direitos humanos só possuem conteúdo real quando o mecanismo de responsabilização por violações é eficaz. Tal mecanismo deve ser o mais amplo possível para que se evite o caráter meramente programático das normas internacionais sobre direitos humanos."

155 Como a presente dissertação centra-se na perspectiva da sociedade civil, e não do Estado, não cabe aqui a investigação dessas dificuldades. 
Estado infrator. A consequência de tal posicionamento para o atual estudo é que o Estado brasileiro não pode justificar o descumprimento de uma obrigação internacional de direitos humanos, alegando a existência de norma constitucional ou mesmo utilizando em sua defesa a teoria da 'separação dos poderes' e o respeito à posição reiterada do Supremo Tribunal Federal ${ }^{156}$. (ibid) (grifo meu)

O Estado brasileiro tem cumprido compromissos internacionais em direitos humanos - i. e. tem subscrito, a partir dos anos noventa, quase que a totalidade de instrumentos internacionais de direitos humanos ${ }^{157}$ e tem agido, no espaço diplomático, de forma contundente em alguns espaços e temas específicos, como atualmente no Conselho de Direitos Humanos das Nações Unidas em relação à questão LGBT, ou mesmo nos anos noventa, quando foi um dos líderes no debate sobre a questão racial junto às Nações Unidas $^{158}$ - de forma bastante ampla, sendo reconhecido como um dos países que mais atua no tema em termos mundiais.

Apesar dessas posições, especialmente no que tange à subscrição de documentos, há espaços em que o Estado brasileiro não consegue avançar da mesma forma.

156 Sobre o tema, continua Ramos (2013, p. 372): "Para o Direito Internacional, essas justificativas são inócuas. As decisões judiciais internas, as normas constitucionais e todas as demais normas e atos internos são apreendidos pelo juiz internacional como meros fatos praticados pelo Estado, não importando qual foi o órgão interno realizador do mesmo (Supremo Tribunal Federal, membro do Poder Executivo, como um delegado da Polícia Federal, ou mesmo o Poder Constituinte Originário).” (grifo meu)

157 Dos tratados internacionais de direitos humanos que existem no âmbito da OEA, o Brasil é subscritor de todos, participando ativamente dos processos de debate e votação de seus textos. O último a ser assinado, em junho de 2015, foi a Convenção Interamericana sobre a Proteção dos Direitos Humanos das Pessoas Idosas. Antes dessa, o corpo diplomático brasileiro foi ativo nos debates, assinados prontamente, em 2013, a Convenção Interamericana Contra o Racismo, a Discriminação Racial e Formas Correlatas de Intolerância e a Convenção Interamericana Contra Toda Forma de Discriminação e Intolerância. O paradoxo, aqui, é evidente, já que o Brasil possui, atualmente, um dos seus congressos mais reacionários desde há ditadura militar lembrando que as Convenções foram, apenas, subscritas, ou seja, há um longo caminho, ainda, para a ratificação). O Brasil encontra-se no seleto grupo de países que cumpre com a chamada universalização dos documentos de direitos humanos e, ainda, submete-se à jurisdição da Corte Interamericana de Direitos Humanos. Em relação às Nações Unidas, existe apenas uma dificuldade: não há perspectivas, apesar do esforço da sociedade civil organizada, para a subscrição do Protocolo Adicional ao PIDESC, que prevê um mecanismo de peticionamento individual junto ao Comitê que monitora o Pacto. O outro documento que demorou muito a ser ratificado foi o do desaparecimento forçado no âmbito da OEA; a demora evidencia resquícios de uma disputa intestina entre governo militar e civil. Quanto ao PIDESC, existe a dificuldade de aceitação, por parte do Estado brasileiro, da garantia de concretização dos direitos econômicos, sociais e culturais. De resto, o Estado brasileiro, em regra, subscreve prontamente os tratados internacionais de direitos humanos.

158 Sobre a atuação diplomática do Brasil em direitos humanos, um dos melhores exemplos é o da campanha que o País promoveu em relação à questão racial nos anos noventa e início dos anos 2000. Ver José Augusto Lindgren Alves (2005). Lembrando que, hoje, a Relatoria da CIDH para o tema, que foi criada a partir de proposição brasileira, não tem financiamento algum para continuar seus trabalhos, quão mais evidencia-se a continuidade da liderança do Brasil no tema. Ao mesmo tempo, o Brasil liderou os debates - e já subscreveu as Convenções sobre Discriminação - tanto Racial, quanto de Todas as Formas - do âmbito da OEA, que se encontram em fase de recolhimento de assinaturas para que se possa colocá-las em funcionamento. Pode-se perceber uma tendência do País - a mesma ainda da época da ditadura, que já foi reportada no trabalho - de subscrição dos documentos, mas, ao mesmo tempo, de enormes obstáculos de, após esse momento, cumprir com as obrigações que ali estão contidas. 
O Sistema Interamericano de Direitos Humanos pode ser tomado como exemplo desse outro lado: o Estado brasileiro aderiu à Convenção Americana de Direitos Humanos em 1992, aceitando a cláusula de jurisdição da Corte IDH em 1998. Contudo, ainda não conseguiu avançar em termos de respostas efetivas ao Sistema Interamericano de Direitos Humanos.

O primeiro obstáculo já foi apontado: o Poder Judiciário - e o Sistema de Justiça como um todo - e sua relação com o direito internacional dos direitos humanos. Poucos são os juízes, promotores, procuradores, advogados, delegados e demais servidores da justiça brasileira que conhecem o SIDH, seus instrumentos e como funciona. O outro obstáculo, daí especificamente em relação à resposta aos casos em trâmite no Sistema Interamericano, é a difícil coordenação entre os órgãos estatais - tanto em função dos níveis federal e estadual, quanto em função dos diferentes atores, a depender do Poder a que se vinculam e a quem estão subordinados - com a finalidade de cumprir as recomendações da CIDH e as sentenças da Corte IDH.

Atualmente, no âmbito da $\mathrm{CIDH}^{159}$, o Estado brasileiro possui i) 11 relatórios de inadmissibilidade; ii) 53 de admissibilidade; iii) 5 de mérito; iv) 17 de arquivamento; v) 1 de solução amistosa; v) 3 casos enviados à Corte IDH e vi) 12 medidas cautelares outorgadas. Países como a Argentina e o México possuem números bem maiores de solução amistosa, por exemplo, o que indica que as partes - organizações da sociedade civil e/ou vítimas e Estado - são mais abertas para utilizar o espaço da CIDH para a negociação de soluções amigáveis $^{160}$.

No âmbito da Corte, o Estado brasileiro possui 4 condenações em sede de sentença - Damião Ximenes Lopes (2006), Sétimo Garibaldi (2009), Escher (2009) e Guerrilha do Araguaia (2010) - e 2 casos apresentados em 2015 pela Comissão Interamericana de Direitos Humanos - Fazenda Brasil Verde e Favela Nova Brasília.

Em relação às medidas de urgência contra o Estado brasileiro, existe uma tendência de sua utilização nos últimos anos, pela sociedade civil, em relação às violações de direitos humanos das pessoas privadas de liberdade. No âmbito da Comissão, há 1

$159 \mathrm{CIDH}$, Estadísticas, disponível em < $<$ http://www.oas.org/es/cidh/multimedia/estadisticas/estadisticas.html>, acesso em outubro de 2015.

160 Para fins de comparação com o Brasil, escolheram-se países de grande população e com estrutura federativa: o Estado argentino possui 8 relatórios de inadmissibilidade, 37 relatórios de admissibilidade, 4 relatórios de mérito, 27 relatórios de arquivamento, 16 relatórios de solução amistosa, 13 casos enviados à Corte IDH e 7 medidas cautelares outorgadas; enquanto o Estado mexicano, 9 de inadmissibilidade, 31 de admissibilidade, 3 de mérito, 19 de arquivamento, 7 de solução amistosa, 6 casos enviados à Corte IDH e 50 medidas cautelares outorgadas. Estadísticas, disponível em

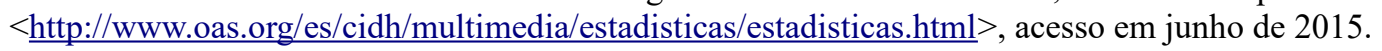


medida cautelar ativa relativamente ao sistema prisional, que é o caso do Presídio Central de Porto Alegre ${ }^{161}$. No âmbito da Corte IDH, há apenas 3 medidas provisórias decretadas contra o Estado brasileiro, todas elas versando sobre violações de direitos humanos de pessoas privadas de liberdade: UNIS é um caso de violações de direitos humanos relativas a adolescentes no sistema socioeducativo do Estado do Espírito Santo; o Complexo Prisional de Pedrinhas é um caso de violações no sistema prisional do Estado do Maranhão; e o Aníbal Bruno/Complexo do Curado é, da mesma forma, um caso relativo ao sistema prisional. Não se pode olvidar do caso Urso Branco, que se encontra com as medidas provisórias levantadas pela Corte IDH, contudo, com monitoramento do "Pacto para Melhoria do Sistema Prisional do Estado de Rondônia e Levantamento das Medidas Provisórias Outorgadas pela Corte Interamericana de Direitos Humanos" pela Comissão Interamericana. Em resumo, há quatro casos de medidas de urgência no SIDH a respeito do sistema prisional brasileiro: Presídio Urso Branco, Presídio Professor Aníbal Bruno/Complexo do Curado, Complexo Penitenciário de Pedrinhas e Presídio Central de Porto Alegre.

Feita essa contextualização, passa-se à análise da estrutura estatal brasileira que responde ao SIDH. A resposta do Estado brasileiro perante o Sistema Interamericano de Direitos Humanos é, atualmente, articulada por três órgãos do Poder Executivo Federal: a Secretaria de Direitos Humanos da Presidência da República ${ }^{162}$, o Ministério das Relações

161 Informação da CIDH sobre a MC 8/13 - Pessoas privadas de liberdade no Presídio Central de Porto Alegre: "El 30 de diciembre de 2013, la CIDH solicitó la adopción de medidas cautelares a favor de las personas privadas de libertad en el Presidio Central de Porto Alegre (PCPA), Brasil. La solicitud de medidas cautelares alega que estas personas estarían en una situación de riesgo debido a las precarias condiciones de detención, hacinamiento extremo, falta de control del Estado en varias áreas del recinto, entre otras situaciones, que podrían afectar su derecho a la vida e integridad personal. Tras analizar los alegatos de hecho y de derecho presentados por los solicitantes y el Estado, la Comisión considera que la información presentada permite suponer que las personas privadas de libertad en el PCPA se encontrarían en una situación de gravedad y urgencia, puesto que sus vidas e integridad personal estarían en grave riesgo. En consecuencia, de acuerdo con el Artículo 25 del Reglamento de la CIDH, la Comisión solicitó al Estado de Brasil que adopte las medidas necesarias para salvaguardar la vida e integridad personal de los internos del Presidio Central de Porto Alegre; que provea condiciones de higiene en el recinto y proporcione tratamientos médicos adecuados para los internos, de acuerdo a las patologías que éstos presenten; que implemente medidas tendientes a recuperar el control de seguridad en todas las áreas del PCPA, siguiendo los estándares internacionales de derechos humanos y resguardando la vida e integridad personal de todos los internos." Disponível $<$ http://www.oas.org/es/cidh/decisiones/cautelares.asp $>$, acesso em outubro de 2015.

162 A maior parte dessa dissertação foi escrita antes da reforma ministerial de outubro de 2015 que modificou a estrutura da então Secretaria de Direitos Humanos da Presidência da República. Como, até o final da confecção do texto, ainda não foram promovidas as modificações de sua estrutura, por meio de norma publicada no Diário Oficial da União, só se pode, aqui, noticiar que a competência e a estrutura da Secretaria de Direitos Humanos da Presidência da República foram absorvidas pelo Ministério das Mulheres, da Igualdade Racial e dos Direitos Humanos; contudo, ainda não se sabe em que termos tal absorção se dará. Encontra-se vigente o Decreto n. 8.162 de 18 de dezembro de 2013; em seu art. $1^{\circ}$, X, dispõe que é da competência da SDH/PR "Encaminhar à Presidente da República propostas de atos necessários para o 
Exteriores e a Advocacia Geral da União.

$\mathrm{Na} \mathrm{SDH} / \mathrm{PR}$, a Assessoria Jurídica e a Assessoria Internacional são responsáveis pela coordenação dos órgãos estatais domésticos envolvidos no cumprimento das recomendações e na resposta ao Sistema Interamericano de Direitos Humanos. Num caso sobre o sistema prisional, por exemplo, normalmente, a SDH/PR coordena o processo de confecção da resposta do Estado brasileiro ${ }^{163}$, com os órgãos estatais que possuem competência para o encaminhamento de soluções para os problemas apontados: no nível federal, o Departamento Penitenciário Nacional do Ministério da Justiça é o principal órgão; no nível estadual, a Secretaria de Segurança Pública ou Justiça, com sua Superintendência ou Subsecretaria de Administração Penitenciária, em geral, é o principal. Contudo, existem, ainda, os órgãos do Sistema de Justiça - Poder Judiciário, Ministério Público, Defensoria Pública, Procuradoria do Estado, Polícias, órgão de perícia forense - que necessitam ser convocados para cumprir com suas tarefas no sentido de proteger as pessoas privadas de liberdade. Além desses atores, por vezes, há necessidade de uma intervenção do Poder Legislativo, a fim de fazer uma modificação ou outra em lei, mas esses casos são mais raros e de intervenção pontual. Esses órgãos devem ser chamados a responder de forma coordenada aos problemas apresentados pelas organizações da sociedade civil. Caracterizam-se, contudo, em seu dia a dia, por não trabalharem de forma articulada. Daí, a importância da coordenação no âmbito doméstico da resposta - que significa a coordenação dos órgãos -, que recai, atualmente, sobre a SDH/PR ${ }^{164}$.

O Ministério das Relações Exteriores, por meio da Portaria n. 212, de 30 de abril

cumprimento de decisões de organismos internacionais motivadas por violação dos direitos humanos e realizar eventual pagamento de valores decorrentes". Daí decorre a competência da Secretaria para o tratamento dos casos do Sistema Interamericano de Direitos Humanos.

163 Importante frisar a diferença entre a resposta formal e a resposta política. Existe uma resposta formal no caso, que é o que se lê na forma de um relatório. Existe, contudo, uma outra resposta, que deve ser articulada de forma política para dar conta dos problemas que são colocados pelos órgãos do SIDH: essa resposta política - na forma de criação/melhoria de políticas públicas - tem de preceder a resposta formal. A adequada resposta formal do Estado brasileiro depende de uma coordenação de seus órgãos a fim de resolver um problema de direitos humanos. Pode-se, dessa forma, encarar cada caso que se encontra no SIDH como uma oportunidade política para que o aparato estatal - que não é homogêneo - possa ser orientado no sentido do cumprimento das obrigações de direitos humanos.

164 Faz-se uma observação: está-se, ainda, em uma fase artesanal quanto à resposta estatal ao SIDH no Brasil. Os órgãos envolvem-se episodicamente e sem um quadro normativo completo para a realização da tarefa. Exemplo disso foram algumas vezes em que a SDH/PR foi excluída, por determinados períodos de tempo, da coordenação da resposta, como no caso das medidas cautelares relativas a Belo Monte (2011-2012) e das medidas cautelares referentes ao Complexo de Pedrinhas (2013-2014). Várias questões políticas e institucionais determinam esse arranjo. Não há espaço para esse debate no presente trabalho, mas não há dúvidas de que seja central para a efetividade das decisões, recomendações e sentenças do Sistema Interamericano de Direitos Humanos no Brasil. 
de 2008, instituiu seu Regimento Interno. Em seu art. $3^{\circ}$, define que, dentro de suas competências, o MRE possui a incumbência de acompanhar e participar da evolução dos aspectos internacionais relacionados a direitos humanos e temas sociais. Por meio de sua estrutura do Departamento de Direitos Humanos e Temas Sociais, e, dentro dele, da Divisão de Direitos Humanos ${ }^{165}$, o Ministério acompanha os casos que se encontram no Sistema Interamericano, trabalhando em estreita parceria com a SDH/PR. Todas as comunicações com os órgãos do SIDH - tanto para Washington, quanto para São José - passam pela Divisão para, somente depois de sua revisão, irem para as missões diplomáticas nessas cidades, onde as manifestações são impressas e entregues a seus destinatários. Além disso, o MRE tem a atribuição de realizar a política externa brasileira ${ }^{166}$, estando presente em todos os fóruns em que o Estado brasileiro se encontra, por exemplo, quando há uma audiência temática na $\mathrm{CIDH}$, em que o Estado brasileiro é chamado, a equipe do MRE encontra-se a postos, a fim de representá-lo naquela ocasião.

A Advocacia-Geral da União, nos termos do artigo 131 da Constituição de $1988^{167}$, é a instituição que representa judicial e extrajudicialmente a União. Dentro da

165 “Art. 48. Compete à Divisão de Direitos Humanos (DDH): I - acompanhar, dirigir e orientar a posição oficial brasileira relativa à promoção e à proteção internacional dos direitos humanos e da democracia, inclusive direitos civis e políticos, direitos econômicos, sociais e culturais, direito ao desenvolvimento, direito à autodeterminação dos povos, direitos da criança, direitos dos povos indígenas, promoção da igualdade racial, prevenção e combate a formas de discriminação e intolerância inclusive por motivo de orientação sexual ou identidade de gênero, promoção da educação em direitos humanos, proteção a defensores de direitos humanos, direitos de minorias nacionais, étnicas, religiosas e linguísticas, direitos humanos de deslocados internos, refugiados, apátridas, migrantes, trabalhadores migrantes e outros grupos vulneráveis, nos níveis multilateral, regional e bilateral; II - acompanhar, dirigir e orientar a representação do Brasil em reuniões, conferências, organismos, negociações e foros internacionais afetos a sua área de atuação, em especial no tratamento dos temas de direitos humanos levados: (...) d) à Organização dos Estados Americanos (OEA), especialmente: 1. à Comissão Interamericana de Direitos Humanos; 2. à Corte Interamericana de Direitos Humanos; (...) VI representar o Ministério junto à Comissão e à Corte Interamericana de Direitos Humanos, bem como acompanhar, supervisionar e coordenar a preparação das respostas do Governo brasileiro aos procedimentos de análise de denúncias de violações de direitos humanos instaurados perante aqueles órgãos e a preparação de visitas de trabalho de seus membros ao país; (...) VIII - acompanhar, coordenar e orientar a política de candidaturas do Brasil aos mecanismos internacionais de promoção e proteção de direitos humanos de sua área de atribuição, especialmente: (...) b) a Comissão e a Corte Interamericanas de Direitos Humanos, o Instituto Indigenista Interamericano e o Instituto Interamericano da Criança e do Adolescente; (...) IX - manter diálogo e cooperação, na área de sua competência, com interlocutores governamentais internos, organizações nãogovernamentais e com o meio acadêmico."

166 A política externa brasileira em direitos humanos tem mudado seu perfil nos últimos anos. Com a qualificação da estrutura e dos servidores da SDH/PR, os agentes estatais que ali atuam estão, cada vez mais, aprimorando-se em sua área de expertise, deixando um espaço menor para a atuação do diplomata. Além disso, a comunicação mudou muito nos últimos anos; há dez anos, havia informações que somente poderiam ser obtidas por um diplomata, de maneira confidencial. Com o desenvolvimento dos meios de comunicação e a maior difusão de informação, o diplomata perdeu o seu maior trunfo: o monopólio da informação. Esse tema merece maiores e mais profundas reflexões, mas, sem dúvida, tais mudanças transformaram e continuam transformando o cenário dos direitos humanos no Brasil e no mundo.

167 O caput do art. 131 da Constituição Federal de 1988 dispõe o seguinte: "A Advocacia-Geral da União é a instituição que, diretamente ou através de órgão vinculado, representa a União, judicial e 
organização administrativa da AGU, compete ao Departamento Internacional, de modo geral, assessorar o Advogado-Geral da União nas questões de Direito Internacional, tanto em processos de celebração de tratados, acordos e ajustes internacionais, bem como na representação judicial e extrajudicial da União nas causas ou controvérsias em foro estrangeiro e em processos judiciais perante os órgãos judiciários brasileiros, decorrentes de tratados, acordos ou ajustes internacionais ou em execução dos pedidos de cooperação judiciária internacional ${ }^{168}$. O DPI/AGU realiza, portanto, a defesa da União no exterior, por meio da propositura de ações em foros estrangeiros, assim como a defesa jurídica do Estado brasileiro em Tribunais Internacionais. Neste contexto, cabe ao DPI/AGU a elaboração de subsídios jurídicos para a defesa perante a Corte Interamericana de Direitos Humanos, em atuação conjunta com outros órgãos competentes ${ }^{169}$.

Atualmente, portanto, a SDH/PR, o MRE e a AGU respondem, em conjunto, pelo Estado brasileiro junto ao Sistema Interamericano de Direitos Humanos. Importante se atentar para a ausência de legislação que normatize as competências e atribuições de cada um dos órgãos, assim como a inexistência de legislação estabelecendo a forma com que o Estado brasileiro responde - agora na acepção política - às demandas do SIDH. Aqui, necessita-se de reflexão a respeito dos sistemas de resposta de outros países, onde existe a chamada lei ponte ${ }^{170}$. No Brasil, tanto o debate relativo à confecção da resposta formal - três órgãos já citados - quanto à da resposta política - que envolve inúmeros órgãos, a depender

extrajudicialmente, cabendo-lhe, nos termos da lei complementar que dispuser sobre sua organização e funcionamento, as atividades de consultoria e assessoramento jurídico do Poder Executivo.” (grifo meu)

168 De acordo com o art. $8^{\circ}$ do Ato Regimental n. 5/2002 da AGU, conforme redação alterada pelo Ato Regimental n. 1 de $1^{\circ}$ de abril de 2005.

169 Informação disponível em <www.agu.gov.br/page/content/detail/id_conteudo/113927>, acesso em junho de 2015.

170 Diferentemente de países como a Colômbia e o Peru, no Brasil, o legislador encontra-se inerte quanto à chamada lei ponte. Em relação aos dispositivos das sentenças que determinam o pagamento de indenização, não há problemas, aparentemente, de ordem prática. Por força do art. 68 da CADH - "a parte da sentença que determinar indenização compensatória poderá ser executada no país respectivo pelo processo interno vigente para a execução de sentenças contra o Estado", aplica-se o Código de Processo Civil, visto que se trata de sentença internacional e não estrangeira (a estrangeira demanda homologação junto ao STJ por comando constitucional). Aparentemente porque persiste a questão da responsabilidade dos estados federados. Da maneira como o quadro normativo encontra-se atualmente, não há forma jurídica alguma de forçá-los ao pagamento da indenização, mesmo que o caso seja preponderantemente de sua competência. A questão mais difícil, contudo, trata-se da internalização das obrigações de fazer e não-fazer impostas ao Estado. Nota-se que a Corte IDH possui um extenso rol delas em sua jurisprudência, tais como ordenar a soltura de pessoa presa, ordenar a construção de uma escola, ordenar a realização de uma cerimônia e pedido público de desculpas, entre outros. Para o cumprimento desse tipo de obrigação, fundamental seria a existência de lei. Atualmente, essas obrigações são cumpridas a partir de acordos e compromissos políticos, de acordo com cada caso. Ainda, importante citar que a lei ponte deve trazer dispositivos sobre como o Estado brasileiro deve atuar nos casos de recomendações e medidas cautelares da $\mathrm{CIDH}$, assim como delimitar o espectro de negociação para o agente público em sede de negociação de solução amistosa. O projeto de lei n. 4.667 encontra-se em trâmite; porém, há modificações importantes para que se torne adequado às reais necessidades que o tema impõe. 
da situação de violação de direitos humanos - está muito tímido no meio acadêmico e da gestão pública, impondo-se encaminhamentos urgentes face a importância do que se encontra em questão.

\subsection{O sistema prisional brasileiro}

O sistema prisional brasileiro é um dos maiores problemas sociais do país, diuturnamente constituindo-se em palco de violações de direitos humanos (ADORNO, 2002). Existe a percepção, há décadas, de que as condições das prisões brasileiras são deploráveis, com problemas básicos de qualidade da água e do ar, ausência de esgoto, temperaturas muito baixas ou muito altas, alimentação ruim ou insuficiente ou estragada, inexistência de local para dormir, falta de produtos de higiene, hiperlotação de espaços, ausência de banho de sol, inexistência de atividades de educação, trabalho e lazer. Para além desses problemas, que já se apresentam de enorme dificuldade de resolução, a omissão estatal dentro das unidades - número reduzido de agentes penitenciários, educadores, assistentes sociais, psicólogos, agentes de saúde, médicos, dentistas - resulta em unidades comandadas e disciplinadas pelos próprios presos. Uma minoria que submete uma maioria sob a égide do terror: mortes, estupros, espancamentos, torturas; ainda, observa-se que há um enorme comércio dentro dos presídios, o que dá margem a outras relações de abuso ${ }^{171}$. Nota-se que essas condições não são somente vivenciadas pelos presos, mas também por suas familiares, que também são subjugadas, contudo, de forma diversa ${ }^{172}$, sob o olhar inerte

$171 \mathrm{Na}$ presente dissertação, o foco reside nas violações de direitos humanos que ocorrem nas prisões. Observa-se, contudo - e deve ser registrado -, que nem todas as relações estabelecidas dentro do sistema prisional brasileiro são de abuso. A minha vivência nos presídios, assim como a minha escuta das organizações da sociedade civil que adentram as cadeias todas as semanas, aponta que existe, da parte da maioria dos presos e na maioria do tempo, grande solidariedade entre as pessoas, inclusive com códigos morais e sociais muito fortes, que fazem com que aquelas condições subumanas sejam possíveis de serem vividas. Existe um debate teórico sobre essas relações estabelecidas, no sentido de que são expressão popular de uma vivência, de um modo de organização. Esse ponto merece melhor reflexão; para tanto. Contudo, um limite claro, parece-me ser que o uso da violência pelos presos em relação a outros presos não pode ser tolerado e deve ser combatido pelos órgãos estatais, em quaisquer circunstâncias, visto que a custódia dos privados de liberdade é do Estado, sendo de sua responsabilidade a vida e a integridade pessoal dessas pessoas.

172 As familiares dos presos são subjugadas de variadas formas, por parte do Estado e também por parte dos presos que formam a elite do presídio - os presos que subjugam os outros presos; no caso de Pernambuco, são os chamados "chaveiros". Desde a questão do jumbo - sacola de alimentos, materiais de higiene e roupa que os familiares têm de levar a cada visita para que seu ente querido tenha como sobreviver - passando pelos pagamentos, por meio de extorsão, que devem realizar - para que o preso possa continuar a viver, para que não seja torturado, para que seja liberado de determinado pavilhão, para que possam fazer a visita, para que possam fazer a visita íntima, entre outros tantos relatos - finalizando com a disposição de seu próprio corpo - há relatos em Pernambuco e no Maranhão de esposas, companheiras, filhas e sobrinhas que foram estupradas dentro das unidades prisionais durante as visitas e as visitas íntimas, sujeitando-se à violência como forma de 
- e, a depender da situação, ativo - do Estado.

A situação de hoje é caótica, com números que apontam um crescimento de $119 \%$ na taxa de aprisionamento da população masculina brasileira no período de 2000 a 2014, segundo dados do Infopen do Ministério da Justiça ${ }^{173}$. Em relação às mulheres, o crescimento foi amplamente superior, consistindo em um crescimento de 567\% no mesmo período $^{174}$. O superencarceramento torna todos os problemas das prisões brasileiras ainda mais graves, além de expor ainda maiores contingentes de pessoas à discriminação, estigmatização, violência e, eventualmente, morte. Ao se pensar nas violações de direitos humanos que ocorrem no sistema prisional, e seu agravamento pela ideologia do superencarceramento e sua prática, deve-se também pensar nas hordas de familiares e amigos que são afetadas pelo seu emprisionamento ${ }^{175}$. Em conclusão, a realidade das prisões é lastimável no país, o que resta comprovado por uma profusão de relatórios da sociedade civil e de órgãos estatais.

O paradoxo que se coloca é o seguinte: hoje, há extensa informação sobre o que ocorre nessas "masmorras modernas". As informações são coletadas, dados são confeccionados, há envolvimento de organizações da sociedade civil, universidades e órgãos estatais no processo. Há, de outro lado, legislação nacional e internacional no sentido de proteção das pessoas privadas de liberdade e de uma execução penal dentro dos parâmetros do Estado Democrático de Direito. Se existe a situação de violação maciça, que se

evitar que seu ente querido fosse morto ou torturado. Nota-se que a esmagadora maioria das visitas aos presídios - tanto masculinos, quanto femininos - é realizada por mulheres e meninas, cumprindo com seu papel social de cuidadoras em função das imposições de gênero. A revista vexatória, mais um suplício pelo qual passam essas mulheres e meninas, é a expressão estatal do quanto vale, na percepção cultural brasileira, a dignidade desse grupo de pessoas, lembrando que há a sobreposição das discriminações em função de serem um grupo majoritariamente formado por mulheres, pobres e negras.

173 O Relatório do Infopen, publicado em junho de 2015, denomina-se "Levantamento Nacional de Informações Penintenciárias - Infopen - Junho de 2014”. Em relação aos números, no relatório $(2015$, p. 16) consta que "Em 2000, havia 137 presos para cada 100 mil habitantes. Em 2014, essa taxa chegou a 299,7 pessoas. Caso mantenha-se esse ritmo de encarceramento, em 2022, a população prisional do Brasil ultrapassará a marca de um milhão de indivíduos. Em 2075, uma em cada dez pessoas estará em situação de privação de liberdade".

174 Sobre o tema, foi publicado o Relatório "Levantamento Nacional de Informações Penitenciárias - Infopen Mulheres - Junho de 2014" (2015, p. 5), ressalta-se o que se segue: "Segundo os últimos dados de junho de 2014, o Brasil conta com uma população de 579.7811 pessoas custodiadas no Sistema Penitenciário, sendo 37.380 mulheres e 542.401 homens. No período de 2000 a 2014 , o aumento da população feminina foi de $567,4 \%$, enquanto a média de crescimento masculino, no mesmo período, foi de $220,20 \%$, refletindo, assim, a curva ascendente do encarceramento em massa de mulheres no Brasil."

175 Para além das violações já citadas que sofrem os familiares dos presos, deve-se observar que as prisões de mulheres, justamente por seu papel social de cuidadoras, afetam toda a sua família, muitas vezes deixando crianças, pessoas com deficiência, pessoas doentes e idosos desguarnecidos. Nesse sentido, interessante a legislação argentina que impõe o dever de maior fundamentação ao juiz para decretação de prisão de uma mulher, visto que sua ausência no âmbito familiar pode, muitas vezes, causar um mal maior que a sua liberdade provisória. 
encontram devidamente registradas, inclusive por órgãos estatais com competência legal para tanto, por que esse estado de coisas apenas piora? E por que as organizações da sociedade civil sentem a necessidade de demandar o sistema internacional de proteção dos direitos humanos, quando há tamanho arcabouço normativo e de instituições nacionais que possuem o dever legal de zelar pelos direitos das pessoas privadas de liberdade no Brasil? Com esses questionamentos, passa-se ao tema do supercencarceramento.

\subsubsection{O fenômeno do superencarceramento no Brasil}

Da mesma forma que o Estado constitui-se em uma criação humana relativamente recente, as prisões também são um advento novo na história da humanidade. Michel Foucault, em seu célebre "Vigiar e punir" (1977), trabalhou a ideia de que a prisão surgiu em fins do século XVIII para substituir os suplícios que eram inflingidos ao corpo práticas de tortura, que eram expostas ao público. Ao debater as características das prisões enquanto espaço de disciplina e vigilância integral dos corpos, e com o enfoque nas "práticas de aprisionamento", o autor mitiga a percepção corriqueira de que a prisão foi um passo civilizatório do Estado moderno.

O Brasil possui uma larga experiência de violação de direitos humanos nas prisões (ADORNO, 2002). Contudo, a presente dissertação busca centrar atenção no atual fenômeno do superencarceramento. Há mais de uma década, o Brasil vem enfrentando um aumento vertiginoso de sua população carcerária, o que tem colaborado sobremaneira para a que as condições na prisão sejam ainda mais agravadas ${ }^{176}$. Em junho de 2014, o Departamento Penitenciário Nacional do Ministério da Justiça divulgou números sobre a população carcerária brasileira, os quais refletem o processo de superencarceramento em curso:

Entre 2000 e 2014, a taxa de aprisionamento aumentou 119\%. Em 2000,

176 Segundo Azevedo \& Cifali (2015, p. 106), “As taxas de criminalidade têm crescido pelo menos desde os anos de aumento da pobreza e hiperinflação que marcaram a transição da ditadura militar para a democracia em meados da década de 1980. O retorno à democracia efetivou-se com a intensificação sem precedentes da criminalidade." Pode-se inferir que, dentro de uma democracia, o Estado precisa, dentro dos parâmetros da legalidade, ainda mais do direito penal para o controle social da sua população. Daí a importância do estudo sobre as sobreposições e relações entre democracia, direito penal e direitos humanos. A radicalização da democracia pode levar ao uso cada vez mais intensivo do direito penal. Sobre o tema, interessante acompanhar projeto de lei que cria o tipo penal do terrorismo no Brasil, que está sendo amplamente criticado pelo campo contra-hegemônico como um instrumento de repressão aos movimentos sociais e organizações da sociedade civil. 
havia 137 presos para cada 100 mil habitantes. Em 2014, essa taxa chegou a 299,7 pessoas. Caso mantenha-se esse ritmo de encarceramento, em 2022, a população prisional do Brasil ultrapassará a marca de um milhão de indivíduos. (MJ, 2015, p. 16)

Os números brasileiros confirmam que o país segue uma tendência de crescimento exponencial da quantidade de pessoas presas no mundo, apontada na literatura (WACQUANT, 2015; CID \& LARRAURI, 2009). O encarceramento em massa, superencarceramento ou hiperencarceramento indica uma situação em que o Estado, detentor do monopólio da violência, aprisiona grandes parcelas de sua população, baseado em discurso de caráter populista penal, dentro de um contexto de economia capitalista neoliberal.

Para Loïc Wacquant (2001), o fenômeno atual não é apenas um processo, mas é um projeto de combinação e complementação da mão invisível do mercado e do punho de ferro do Estado. Esse projeto amolda-se a esse novo ciclo do capitalismo, a que as pessoas devem se adaptar, sendo que aos mais pobres cabe aceitarem a piora das condições sociais, o que é facilitado pela sensação de instabilidade na área da segurança pública. Segundo Wacquant, esse projeto, que teve adesão há alguns anos pelos Estados Unidos e Europa, compõe-se de três transformações distintas.

\begin{abstract}
Apagar o Estado econômico, desmantelar o Estado social e fortalecer o Estado penal: essas três transformações estão intimamente ligadas uma à outra e todas as três resultam essencialmente de uma conversão das classes dominantes à ideologia neoliberal. ${ }^{177}$ (tradução livre) (WACQUANT, 2001, p. 404)
\end{abstract}

No Brasil, existem algumas peculiaridades atinentes ao fenômeno. Há alguns anos, os criminólogos críticos atacavam duramente o RDD - regime disciplinar diferenciado, quando este se encontrava em trâmite legislativo, afirmando que sua criação

177 O papel do neoliberalismo econômico e político é central nessa análise sobre o supercencarceramento, conforme propõe Wacquant (2001, p. 404): "In fact, those who are glorifying the penal state today, in America as well as in Europe, are the same ones who, yesterday, were demanding the end of 'Big government' on the social and economic front, and who did indeed succeed in curtailing the prerogatives, expectations, and exigencies of the collectivity in the face of the market - that is, in the face of the dictatorship of large corporations. This may seem like a contradiction, but in reality these are the two components of the new institutional machinery for managing poverty that is being put in place in the era of mass joblessness and precarious employment. This new 'government' of social insecurity - to use Michel Foucault's terminology rests, on the one hand, on the disciplining of the deskilled and deregulated labour market and, on the other, on an intrusive and omnipresent penal apparatus. The invisible hand of the market and the iron fist of the state combine and complement each other to make the lower classes accept desocialised wage labour and the social instability it brings in its wake. After a long eclipse, the prison thus returns to the frontline of institutions entrusted with maintaining social order." (grifo meu) 
seria um instrumento a serviço do superencarceramento. Salo de Carvalho e Christiane Russomano Freire (2007, p. 270), ao criticarem o RDD, afirmam "o irreversível ingresso do país nos modelos punitivos de hiperpunitividade que atingem os Estados que têm optado por políticas criminal e penitenciária sustentadas pelos discursos de Lei e Ordem e Tolerância Zero."

Nos dias de hoje, o superencarceramento é gerado fundamentalmente pela aplicação da Lei Federal n. 11.343, de 23 de agosto de 2006, a Lei de Drogas, que produziu a possibilidade legislativa - que foi amplamente aproveitada pelos outros agentes públicos para se levar ao extremo a lógica do inimigo pelo Sistema de Justiça brasileiro (BOITEUX, 2015). Dentro dessa lógica, as polícias - agentes públicos que prendem as pessoas -, o Ministério Público - agentes públicos que confeccionam a denúncia contra o preso -, e o Poder Judiciário - agentes públicos que decretam a prisão provisória ${ }^{178}$, com base, na quase totalidade das vezes, apenas no testemunho do policial militar que realiza a prisão - apoiamse uns nos outros, dentro de uma ordem mecanizada, que indica, desde o princípio, quem é o inimigo que deve ser perseguido.

Nesse contexto, deve-se notar que, no Brasil, a seletividade penal encontra-se fortemente incrustada nas instituições do Sistema de Justiça. A seletividade é um conceito central para a compreensão do fenômeno do superencarceramento; aqui, está exemplarmente explicada da seguinte forma por Eugenio Raúl Zaffaroni (2009, p. 72-73):

É indiscutível que em toda a sociedade existe uma estrutura de poder e segmentos ou setores mais próximos - ou hegemônicos - e outros mais alijados - marginalizados do poder. Obviamente, esta estrutura tende a sustentar-se através do controle social e de sua parte punitiva, denominada sistema penal. Uma das formas mais violentas de sustentação é o sistema penal, na conformidade da comprovação dos resultados que este produz sobre as pessoas que sofrem os seus efeitos e sobre aquelas que participam nos seus seguimentos estáveis. Em parte, o sistema penal cumpre esta função, fazendo-o mediante a criminalização seletiva dos marginalizados,

178 Prisão provisória é uma prisão precária, realizada sem base em condenação definitiva. É gênero de que fazem parte a prisão por flagrante, a preventiva e a temporária. Grande parte dos presos no Brasil são presos provisórios, ou seja, pessoas que estão presos sem que o devido processo legal tenha tramitado, a fim de que seja produzida uma condenação definitiva. Sobre esse ponto, "No Brasil, cerca de $41 \%$ das pessoas privadas de liberdade são presos sem condenação. Significa dizer que quatro a cada dez presos estão encarcerados sem terem sido julgados e condenados. A figura 10 mostra que, entre as Unidades da Federação, a variância dessa taxa é ampla: enquanto apenas $16 \%$ das pessoas privadas de liberdade em Roraima são presos provisórios, em Sergipe 7 em cada 10 presos encontram-se nessa situação. Além deste estado, outras sete Unidades da Federação têm uma quantidade maior de presos provisórios do que condenados: Maranhão, Bahia, Piauí, Pernambuco, Amazonas, Minas Gerais e Mato Grosso.” (MINISTÉRIO DA JUSTIÇA, 2015, p. 21) (grifo meu) 
para conter os demais. ${ }^{179}$

O resultado, num país com a estrutura social e política do Brasil, é o aprisionamento de uma massa carcerária composta majoritariamente por pessoas jovens, pobres, negras e com baixa escolaridade ${ }^{180}$. As pessoas privadas de liberdade, além de sofrerem em função da discriminação e da sua condição de pobreza, padecem com as péssimas condições das prisões, que em larga medida remontam as experiências nazistas de campos de concentração (WACQUANT, 2015; ZAFFARONI, 2007). Devido à história brasileira e todas às mazelas de sua sociedade, arrisco a ideia de que não remontam campos de concentração, mas, sim, senzalas. Importante relacionar o fenômeno do superencarceramento, sobre o qual gravitam as questões relativas à seletividade, prática de tortura e execuções policiais, com a experiência da colonialidade que constituiu o continente e que, ainda, produz seus efeitos. O superencarceramento de hoje tem relação com a ditadura de ontem, que, por sua vez, também se relaciona com o extermínio e expropriação, bases da fundação das nações latino-americanas (SEGATO, 2007, p. 143-144).

Pode-se traçar um paralelo entre os casos sobre violações de direitos humanos no sistema prisional brasileiro que se encontram no Sistema Interamericano e o fenômeno do superencarceramento. Pode-se traçar, portanto, uma relação entre a quantidade de casos perante o Sistema Interamericano e o aumento do número de presos no Brasil, que resulta na piora da situação prisional, que se está a testemunhar ao longo dos últimos anos.

Por outro lado, mesmo que se trabalhe com alguns casos específicos que estão na Comissão e na Corte Interamericana ou mesmo com a confecção de rankings das piores prisões no Brasil, como foi realizado pela CPI do Sistema Carcerário entre 2007 e $2008^{181}$,

179 Continua o autor: "E também em parte, quando os outros meios de controle social fracassam, o sistema não tem dúvida em criminalizar pessoas dos próprios setores hegemônicos, para que estes sejam mantidos e reafirmados no seu rol, e não desenvolvam condutas prejudiciais à hegemonia dos grupos a que pertencem, ainda que tal fenômeno seja menos frequente (criminalização de pessoas ou de grupos contestadores pertencentes às classes média e alta). Também, em parte, pode-se chegar a casos em que a criminalização de marginalizados ou contestadores não atenda a nenhuma função em relação aos grupos a que pertencem, mas unicamente sirvam para levar uma sensação de tranquilidade ais mesmos setores hegemônicos, que podem sentir-se inseguros por qualquer razão (geralmente, por causa da manipulação dos meios massivos de comunicação). Em síntese, o sistema penal cumpre uma função substancialmente simbólica perante os marginalizados ou os próprios setores hegemônicos (contestadores e conformistas). A sustentação da estrutura do poder social por meio da via punitiva é fundamentalmente simbólica." (grifo meu) 180 Relatório do Ministério da Justiça. INFOPEN, 2015, p. 6 e 48-60.

181 De acordo com o Relatório (2009, p. p. 488-489), esse é o ranking das piores unidades prisionais: $1^{\circ}$ Presídio Central de Porto Alegre/RS; $2^{\circ}$ Colônia Agrícola de Campo Grande/MS; $3^{\circ}$ Distrito Policial de Contagem/MG, Delegacias de Valparaíso/GO, 52 $\mathrm{DP}$ de Nova Iguaçu e $54^{\mathrm{a}} \mathrm{DP}$ de Mesquita, ambas do Rio de Janeiro; $4^{\circ}$ Presídio Lemos de Brito/BA, Vicente Piragibe/RJ, Presídio Aníbal Bruno/PE, Penitenciário Masculina Doutor José Mário Alves da Silva "Urso Branco"/RO, Complexo Policial de Barreiras/BA; 50 
não se pode perder de vista, como apontam Wacquant e Zaffaroni, que as mazelas do sistema prisional no Brasil são estruturais, e, como tal, devem ser tratadas.

Uma crítica possível, a partir da perspectiva do superencarceramento, ao tratamento e aos encaminhamentos feitos pelo Estado brasileiro no âmbito dos referidos casos de medidas cautelares e provisórias no SIDH, é que solução não se encontra na produção de mais vagas no sistema prisional brasileiro. A captação de recursos financeiros do Fundo Penitenciário para a produção de mais vagas no sistema prisional, a fim de diminuir o deficit de vagas, não é compatível com a busca de uma solução estrutural. Afora os possíveis rankings que possam ser montados, ou mesmo os números alarmantes da superpopulação, é imprescindível a afirmação de que a situação de violação de direitos humanos em nossos presídios é estrutural e não apenas questão isolada em uma ou outra unidade. O risco que se corre ao se isolar unidades em rankings ou mesmo em uma lista de unidades que estão se encontram no Sistema Interamericano de Direitos Humanos é justamente esse: ao se centrar o olhar nas violações de direitos humanos ocorridas em uma unidade, foca-se apenas em um problema e perde-se a noção do todo.

Nesse sentido, o debate sobre um limite para a quantidade de pessoas presas é enorme relevância, para além da garantia de condições dentro dos presídios. Zaffaroni, em entrevista de Julita Lemgruber, analisa uma série de fenômenos envolvendo a segurança pública e o sistema prisional no Brasil. Ao responder a uma pergunta sobre a aplicação extensiva do regime disciplinar diferenciado, diz que "a solução não é construir mais cadeias, mas diminuir o número dos presos" (2007, p. 137). Continua, afirmando que

Cada país decide o número de presos que quer ter na cadeia (...) Se o Estado decidir ter mais presos, deve tê-los em condições minimamente adequadas de vida. Quando não puder, deve reduzir o número, adotar uma outra política a respeito dos presos por crimes de gravidade média. (2007, p. 137-138) (grifo meu)

Conquanto o problema do superencarceramento seja estrutural no Brasil, sendo apenas um desdobramento de uma das facetas do novo ciclo capitalista, não se pode ignorar

Centro de Detenção Provisória de Pinheiros/SP; $6^{\circ}$ Instituto Masculino Paulo Sarasate/CE; $7^{\circ}$ Penitenciária Feminina Bom Pastor/PE; $8^{\circ}$ Penitenciária Feminina de Santa Catarina/SC; $9^{\circ}$ Casa de Custódia Masculina do Piauí/PI; $10^{\circ}$ Casa de Detenção Masculina SEJUC/MA. Interessante observar que os quatro casos que se encontram com medidas de urgência estão nesse ranking, a saber o Presídio Central de Porto Alegre, o Complexo do Curado (antigo Aníbal Bruno), o Urso Branco e parte do Complexo de Pedrinhas (Casa de Detenção Masculina SEJUC). Nota-se que os 4 casos que se encontram no SIDH - Urso Branco, Aníbal Bruno, Pedrinhas e Presídio Central - figuram no ranking da CPI do sistema carcerário. 
o sofrimento humano que existe por trás das violações de direitos humanos que ocorrem diuturnamente no Presídio Aníbal Bruno. O argumento do superencarceramento deve ser somado a todos os outros que vão ao encontro de soluções construtivas e adequadas aos problemas enfrentados no dia a dia. Ou seja, não se trata de apenas debater o superencarceramento e esquecer-se do resto: trata-se de incorporar, quando do momento criativo de pensar em soluções para os problemas do sistema prisional de Pernambuco, a linha argumentativa em torno do tema, a fim de buscar respostas contra-hegemônicas às questões do sistema prisional e não reforçar a já conhecida forma da construção de mais e mais vagas e unidades para o encarceramento de pessoas.

\subsubsection{Registrando a realidade da miséria nas e das prisões}

A realidade dos dados é assustadora: o país caminha, a passos largos, para se tornar a terceira maior população carcerária do mundo, somente atrás dos Estados Unidos e China $^{182}$. Dentro dessa cultura de direito penal máximo ${ }^{183}$ e aprisionamento, já apontada, a produção de dados e informações sobre a situação dos presos no país mostra-se crucial para que se possa enfrentar o problema com o conhecimento pleno da realidade.

Uma referência nesse sentido foi o relatório da Comissão Parlamentar de Inquérito da Câmara dos Deputados, que foi publicado em 2009. Em 2007, frente a rebeliões, motins, mortes de presos, agentes de segurança pública e familiares, assim como organizações comandando o crime de dentro das unidades prisionais ${ }^{184}$, a Câmara de Deputados constituiu uma Comissão Parlamentar de Inquérito a fim de

182 Cf. dados do ICPS - Centro Internacional de Estudos Prisionais, do King's College, de Londres, em $<$ http://www.prisonstudies.org/world-prison-brief $>$, acesso em outubro de 2015.

$183 \mathrm{O}$ direito penal máximo é um dos instrumentos desse novo ciclo do capitalismo, conforme Wacquant (2001). Portanto, vale uma brevíssima reflexão sobre o papel dos movimentos e organizações de direitos humanos nesse debate, dado o seu caráter contra-hegemômico. Que sentido existe em uma pauta baseada na criminalização das práticas discriminadoras, quando, na outra ponta, movimentos e organizações ligadas a direitos humanos advogam pelo direito penal mínimo ou, até, pelo abolicionismo penal? Essa contradição encontra-se evidente na busca dos movimentos pelo direito penal como resposta ao racismo, à lesbo-, homo- e transfobia e à violência contra a mulher, com a criação do tipo penal do feminicídio. Essa questão merece reflexão posterior.

184 A percepção sobre a força política e social das organizações criminosas fica evidente no Relatório (2009, p. 14), que traz o seguinte argumento com justificativa de criação da CPI: "Deparamos-nos, ainda, com a insegurança que vem dos estabelecimentos penais, de onde grupos organizados controlam e manipulam a massa de presos pobres e despolitizados, e de lá comandam uma rede de subordinados e aliados na prática dos mais variados ilícitos. A força e o poder desses grupos é tanta que chegaram a parar a cidade de São Paulo, desafiando autoridades e atacando instituições - como ocorreu em 2006 - ou simplesmente dividindo espaço com o poder público constituído como ocorre no Rio de Janeiro.” 
Investigar a realidade do sistema carcerário brasileiro, com destaque para a superlotação dos presídios, custos sociais e econômicos desses estabelecimentos, a permanência de encarcerados que já cumpriram pena, a violência dentro das instituições do sistema carcerário, a corrupção, o crime organizado e suas ramificações nos presídios e buscar soluções para o efetivo cumprimento da Lei de Execuções Penais. (2009, p. 41-42)

Em oito meses de atividade, entre 2007 e 2008, a CPI realizou audiências com autoridades federais e estaduais dos poderes Executivo, Judiciário e Legislativo, especialistas, pesquisadores, jornalistas, policiais, representantes da sociedade civil e dos agentes penitenciários na Câmara dos Deputados. Presente em 18 Estados, a Comissão realizou audiências públicas, colhendo depoimentos de autoridades, representantes de entidades da sociedade civil, líderes dos agentes penitenciários e das pessoas privadas de liberdade, tanto em audiências públicas quanto reservadas.

A CPI do Sistema Carcerário, cujo relator foi o Deputado Federal Domingos Dutra, então do Partido dos Trabalhadores pelo Estado do Maranhão, foi um marco referente à denúncia e à problematização do contexto histórico-social em que se situa a prisão brasileira. Pautou-se especialmente pela busca de "soluções e alternativas capazes de humanizar o sistema prisional do país, contribuindo com a segurança da sociedade" (2009, p. 41). O relatório não produziu desdobramentos práticos evidentes; contudo, todos os relatórios que se seguiram o tomam como referência. A contribuição mais interessante do processo da CPI foi engajar todos esses atores sociais já referidos no processo de levantamento de dados e debates sobre o sistema prisional. Como já se advertiu, há obstáculos na coordenação de trabalho entre instituições diferentes, portanto, essa iniciativa foi um passo importante para a visibilização do problema e da necessidade de colaboração dos diversos órgãos públicos para a busca de soluções para o sistema prisional brasileiro.

Destaca-se a atuação da sociedade civil nessa área de levantamento de dados e reflexão sobre o sistema prisional. De formas diferentes, em maior ou menor profundidade, organizações têm se posicionado a respeito do tema, em consonância sobre sua gravidade e complexidade, dentro da área de direitos humanos no Brasil. Anistia Internacional ${ }^{185}$, Human

185 A Anistia Internacional, em seu relatório sobre a situação dos direitos humanos no Brasil em 2014, referiu que o ano de 2014 foi marcado pelo agravamento da crise da segurança pública no Brasil. Uma das principais questões apontadas foram as rebeliões com mortes violentas em presídios superlotados e casos de tortura. 
Rights Watch ${ }^{186}$, Conectas ${ }^{187}$, além da Pastoral Carcerária e Justiça Global - representantes dos beneficiários no caso Aníbal Bruno - que trabalham diretamente com casos do sistema prisional, levantando dados no dia a dia de seu monitoramento e produzindo relatórios periódicos com seus resultados.

Afora a sociedade civil organizada, os órgãos estatais que fazem o controle do sistema prisional também desenvolveram a prática de produção de relatórios. Normalmente, compõe-se de duas partes: levantamento de dados e recomendações. Dentre os órgãos de âmbito nacional, destacam-se o Conselho Nacional de Justiça - CNJ, o Conselho Nacional do Ministério Público - CNMP, o Conselho Nacional de Política Criminal e Penitenciária CNPCP e a Ouvidoria do Departamento Penitenciário Nacional do Ministério da Justiça OSPEN.

O CNJ possui uma área específica para o tratamento de casos do sistema prisional que é o Departamento de Monitoramento e Fiscalização do Sistema Carcerário e do Sistema de Execução de Medidas Socioeducativas - DMF ${ }^{188}$. Uma das principais atuações do DMF é a realização dos mutirões carcerários, que produzem, entre outros resultados, relatórios sobre a situação do sistema prisional dos Estados federados visitados. Com base nesse diagnóstico, o DMF faz recomendações às instituições do Sistema de Justiça. Especificamente em relação ao caso Aníbal Bruno, o CNJ produziu 2 relatórios - 2011 e 2014 - sobre os mutirões realizados na unidade.

O CNMP, da mesma forma que o CNJ, possui uma unidade especializada sobre o sistema prisional, que também realizam inspeções e confeccionam relatórios. Em 2013,

186 A Human Rights Watch, além de ressaltar as violações de direitos humanos nos presídios brasileiros em seu relatório anual de 2014, produziu um relatório específico sobre a situação do sistema prisional de Pernambuco em outubro de 2015. Intitulado "O Estado Deixou o Mal Tomar Conta" - A Crise do Sistema Prisional do Estado de Pernambuco, o relatório trata da superlotação, da questão da saúde, dos "chaveiros", das audiências de custódia, dos atrasos judiciais injustificados e das obrigações do Brasil perante o direito internacional.

187 A Conectas, em seu relatório 2013-2014, denuncia o caso do Complexo Penitenciário de Pedrinhas, no Maranhão, assim como a política de encarceramento e a criminalização da pobreza. Ainda, presta contas sobre sua atuação no monitoramento do sistema prisional brasileiro. Merece nota a participação da Conectas na audiência temática na Comissão Interamericana em 20 de outubro de 2015 sobre a audiência de custódia. Pedida pelo Estado brasileiro a fim de expor a nova experiência do Poder Judiciário, a audiência teria sido apenas uma apresentação do sucesso da nova experiência se não fossem os dados apresentados pela organização. A partir do acompanhamento de audiências, a organização concluiu que existem graves deficiências na condução das audiências, que estão servindo, em resumo, apenas como uma forma de diminuir o input no sistema prisional, mas não como instrumento de prevenção e combate à tortura, função que faz parte da natureza do instituto.

188 Estrutura criada pela Lei Federal n. 12.106 de dezembro de 2009, com a finalidade de verificar as condições de encarceramento, as ações de reinserção social dos presos, $\mathrm{o}$ andamento dos processos criminais, a execução penal e o atendimento aos adolescentes em conflito com a lei. 
produziu um relatório sobre o sistema prisional brasileiro, que compila informações das inspeções realizadas pelo órgão, apontando a realização de inspeções e a produção de relatórios como instrumentos que permitirão a identificação de "experiências positivas e os pontos em que haja ainda necessidade de maior aprimoramento" (2013, p. 23). Ainda, há a indicação que tal expediente auxilia o Ministério Público, no sentido de que, assim, tem informação para decidir “onde e como agir, por meio do diálogo, da celebração de acordos e de parcerias com o Poder Público e, finalmente, por meio da propositura de ações para garantir o respeito efetivo aos direitos humanos no cumprimento das penas" (2013, p. 23). Em relação especificamente ao Aníbal Bruno, o CNMP realizou visita e fiscalização em 7 e 8 de maio de 2013, produzindo relatório datado de 26 de junho de 2013. O relatório descreve uma série de problemas na unidade e faz recomendações ao final.

No âmbito do Ministério da Justiça, funcionam o CNPCP e o Departamento Nacional Penitenciário com sua Ouvidoria. Antes de fazer referência a esses órgãos, deve-se anotar que a base de dados sobre o sistema prisional brasileiro é de sua atribuição - o Infopen. O Infopen é um sistema de informações estatísticas do sistema penitenciário brasileiro, que é atualizado pelos gestores desde 2004. Sua função principal é sintetizar informações sobre os estabelecimentos penais e sua população prisional. Importante observar que, dentro dessa tendência de órgãos estatais criarem/melhorarem bases de dados e produzirem informações e relatórios sobre o sistema prisional, o Infopen, em 2014, passou por diversas alterações quanto à sua metodologia e seu instrumento de coleta de informações para o aprimoramento do diagnóstico do sistema prisional ${ }^{189}$. A finalidade desse aprimoramento constitui-se na possibilidade de elaboração de políticas públicas cada vez mais adequadas à realidade prisional $(2015$, p. 8$)$.

A Ouvidoria do Sistema Penitenciário, assim como o próprio DEPEN, acompanham de forma muito próxima o caso Aníbal Bruno. Já foram realizadas várias inspeções, diligências, reuniões técnicas e outras atividades relativas à unidade. Relatório de

189 Essas modificações foram apresentadas à sociedade brasileira em junho de 2015 com a publicação do Levantamento Nacional de Informações Penitenciárias - Infopen - Junho de 2014. Na apresentação (2015, p. 6-7), o Ministro José Eduardo Cardozo e o Diretor-Geral do DEPEN Renato Campos Pinto De Vitto observam que "A situação carcerária é uma das questões mais complexas da realidade social brasileira. O retrato das prisões apresentado neste Relatório do Infopen desafia o sistema de justiça penal, a política criminal e a política de segurança pública. $\mathrm{O}$ equacionamento de seus problemas exige, necessariamente, o envolvimento dos três Poderes da República, em todos os níveis da Federação, além de se relacionar diretamente com o que a sociedade espera do Estado como ator de pacificação social. (...) Nesse cenário, este Relatório do Infopen é uma importante ferramenta para o conhecimento da realidade prisional brasileira. O processo de revisão e ampliação do escopo dos dados coletados e os exercícios de tratamento dos dados, conforme explicações das notas metodológicas, representa grande avanço na política de gestão da informação do Depen”. 
inspeção da OSPEN no Presídio Professor Aníbal Bruno foi inclusive utilizado pelos representantes dos beneficiários para ilustrar a situação em que se encontrava a unidade. Ainda, evidencia o quão heterogêneo é o Estado brasileiro, em um sistema de sobreposição de competências e controles, que deveria gerar melhores resultados práticos.

O CNPCP - Conselho vinculado ao Ministério da Justiça - possui, entre suas atribuições, a inspeção e a confecção de relatórios sobre os sistemas prisionais dos Estados federados. Em relação a Pernambuco, o Conselho já se fez presente inúmeras vezes em suas unidades. Sua última visita ao Estado foi realizada em 30 e 31 de março de 2015. Duas das três unidades do então Presídio Aníbal Bruno - Presídio Juiz Antônio Luiz Lins de Barros (PJALLB) e Presídio Frei Damião de Bozzano (PFDB) - foram visitadas. As recomendações foram feitas aos órgãos separadamente ${ }^{190}$, emitidas ao Governador do Estado de Pernambuco, ao Presidente do Tribunal de Justiça de Pernambuco e a Corregedoria Geral de Justiça do Tribunal de Justiça de Pernambuco, ao Secretário de Estado da Justiça e Direitos Humanos de Pernambuco e Secretário Executivo de Ressocialização, ao Presidente do Tribunal de Justiça e ao Secretário Executivo de Ressocialização - apenas uma recomendação para a cooperação entre os órgãos no sentido da articulação com o Conselho Nacional de Justiça e o Departamento Penitenciário Nacional com a finalidade de implementação da Audiência de Custódia com a apresentação dos presos em flagrante -, ao

190 O relatório e as recomendações estão muito bem confeccionadas, atendendo à especificidade de cada problema e à competência de cada órgão envolvido. Em função da extensão das recomendações, que possuem 58 pontos, não serão reproduzidas todas as recomendações. Contudo, a título de exemplo, dispõem-se aquelas relativas ao Governador do Estado de Pernambuco: "1. Que crie uma Ouvidoria do Sistema Penitenciário específica, nos termos da resolução nº3/2014 - CNPCP, com estrutura adequada e autônoma, com Ouvidor (a) externo (a) e com mandato próprio, tendo em vista que a Ouvidoria existente pertence à estrutura da Secretaria de Justiça e Direitos Humanos. 2. Que crie uma Corregedoria do Sistema Penitenciário específica, com estrutura adequada e autônoma, com Corregedor (a) externo (a) e com mandato próprio. 3. Que os (as) 67 defensores (as) públicos (as) aprovados (as) no concurso em andamento sejam nomeados com a urgência que o caso requer e sejam alocados de preferência nos estabelecimentos penais mais necessitados, visando ampliar as ações da Defensoria Pública em todas as fases processuais e fortalecer os núcleos voltados à execução penal. 4. Que sejam providos, através de concurso público, todos os demais cargos vagos de defensores públicos, a fim de garantir o acesso à justiça aos privados de liberdade. 5. Que, na realização de concurso público previsto para contratação de 200 agentes penitenciários para atuação no sistema prisional do estado, haja ampliação desse quantitativo, tendo em vista que, apenas para suprir o déficit existente, o Estado precisaria de, no mínimo, mais 2.200 agentes penitenciários. 6. Que intensifique o programa de monitoramento eletrônica para aos presos provisórios e do regime semi-aberto como forma de desencarceramento suprindo a ausência de vagas, não sendo usado o monitoramento como uma política de segurança pública a exemplo da saída temporária. 7. Que reavalie o programa Pacto pela Vida, evitando a adoção de política de incentivo ao encarceramento como opção para redução de índices de criminalidade. 8. Que articule com o Conselho Nacional de Justiça, o Departamento Penitenciário Nacional, Tribunal de Justiça, Secretaria de Defesa Social, Secretaria de Justiça, Defensoria Pública e Ministério Público para a implementação da Audiência de Custódia com a apresentação dos presos em flagrante, para fiscalizar a legalidade das prisões, racionalizar o uso da prisão cautelar e viabilizar de aplicação de medidas alternativas a prisão preventiva. 9. Que promova a ampliação de vagas no sistema penitenciário pernambucano." 
Secretário de Estado da Justiça e da Cidadania e ao Secretário de Saúde, ao Defensor Público Geral de Pernambuco, ao Ministério Público do Estado de Pernambuco.

Mais recentemente, com a superveniência da Lei Federal n. 12.847, de 2 de agosto de 2013, foi criado o Sistema Nacional de Prevenção e Combate à Tortura SNPCT $^{191}$, que compreende o Comitê Nacional de Prevenção e Combate à Tortura - CNPCT e o Mecanismo Nacional de Prevenção e Combate à Tortura - MNPCT. O Mecanismo Nacional é composto por 11 especialistas independentes, que têm acesso às unidades de privação de liberdade, como centros de detenção, estabelecimento penal, hospital psiquiátrico, comunidade terapêutica, abrigo de pessoa idosa, instituição socioeducativa ou centro militar de detenção disciplinar. O instrumento utilizado pelo Mecanismo, quando constatadas violações, é o da elaboração de relatórios com recomendações às autoridades competentes $^{192}$. O Comitê Nacional, por sua vez, é um colegiado composto por 23 membros, 11 representantes de órgãos federais e 12, da sociedade civil. Para além de acompanhamento de ações e programas para a erradicação da tortura no Brasil, de proposições legislativas, e de trâmites de apuração administrativa e judicial, um dos focos do Comitê é a sistematização de informações em um banco de dados relacionado às denúncias e às respostas institucionais e estatais.

Demonstrou-se que o Estado brasileiro, por meio de variados órgãos, e, ainda, a sociedade civil produzem uma quantidade enorme de informação sobre o sistema prisional. Para além da ideia do panóptico, de que o agente possui total controle sobre rotina do preso, pode-se afirmar que houve sua expansão: tem-se informação registrada sobre todos os aspectos da prisão, inclusive aqueles que deveriam necessariamente gerar uma ação estatal. O Estado brasileiro - e aqui não importa qual seja o órgão: todos são Estado brasileiro - não pode ignorar as informações registradas em detalhes dos crimes ocorridos dentro das unidades, espaços em que as vítimas são integralmente custodiadas pelo Estado, razão pela qual o Estado possui, em relação a essas pessoas, especial responsabilidade internacional, segundo jurisprudência da Corte IDH.

191 O SNPCT também é composto pelo Conselho Nacional de Política Criminal e Penitenciária e pelo Departamento Penitenciário Nacional do Ministério da Justiça. Outras instituições podem solicitar a inclusão no Sistema, como organizações da sociedade civil, órgãos do Poder Judiciário, Conselhos Tutelares e corregedoria e ouvidorias de polícia por meio de instrumento de adesão ao SNPCT. A participação dos Comitês e Mecanismos Estaduais é aceita mediante um termo de adesão específico.

192 Até a finalização dessa dissertação, o Mecanismo Nacional não realizou visita, tampouco confeccionou relatório sobre o Complexo do Curado/Presídio Professor Aníbal Bruno. Há previsão de visita no primeiro semestre de 2016. 


\subsubsection{O abismo entre a riqueza normativa e de instituições e a miséria das prisões}

O Brasil é um país cheio de paradoxos - um deles se refere ao abismo existente entre seu quadro normativo e a realidade social enfrentada pela grande maioria de sua população. Esse paradoxo evidencia-se plenamente no sistema prisional brasileiro: justamente porque a seletividade do direito penal ${ }^{193}$ atua no sentido de escolher a parcela mais pobre, jovem e negra como clientela. É um dos poucos países em que a pena de morte foi abolida há décadas, enquanto os esforços dos organismos internacionais de direitos humanos ainda são enormes na tentativa de extirpar a previsão da pena de morte, ou penas humilhantes e degradantes, dos ordenamentos jurídicos de um grande contingente de países do mundo. A Lei de Execução Penal brasileira ${ }^{194}$ é aclamada como uma das mais progressistas do mundo ocidental, em plena consonância com as Regras Mínimas para Tratamento de Presos da ONU. Direitos ao trabalho, à educação e à visita íntima, que não são assegurados à população carcerária de muitos países, encontram-se plasmadas na legislação brasileira. Contudo, dada a situação encontrada na miséria das e nas prisões, essa legislação não é concretizada na realidade das pessoas privadas de liberdade no país.

Ela Wiecko V. de Castilho (1988), ao acompanhar o processo de debates e a superveniência da Lei de Execuções Penais ${ }^{195}$, que foi promulgada em 1984, discorre sobre a legalidade da execução penal. Àquela época, a execução penal ainda não era considerada

193 A seletividade do direito penal é uma das categorias trabalhadas pelos teóricos da criminologia crítica. Segundo Andrade (2013, p. 340), a seletividade opera da seguinte forma: "Consolidou-se, assim, seletivamente, uma identificação da criminalidade com 'a' criminalidade dos baixos estratos sociais (dominantemente recortada pela seletividade de gênero e racial), a qual, amalgamada com a ideologia da periculosidade e dos sujeitos e/ou grupos perigosos, acabou por estabelecer uma identificação com 'a' violência, fazendo este conceito se subsumir integralmente naquele. Daí resulta que a consolidação dos estereótipos de criminalidade e de criminosos (perigosos) e do medo e do sentimento de insegurança contra estes, numa sociedade cada vez mais comandada pelo poder do espetáculo midiático, foi um passo. Aliás, torna-se sempre um passo para a construção de novas emergências." (grifo meu)

194 A LEP, a princípio, apenas regulamenta os direitos e deveres dos presos condenados definitivamente pelo Estado. Num país como o Brasil, em que em torno de $40 \%$ da população carcerária é composta por presos provisórios, tal divisão - uma parte dos presos é protegida pela LEP e outra parte, não - é problemática para a solução prática dos problemas. Tendo-se em vista que as penas estão submetidas no atual modelo ao juiz, e que a especialização em varas da execução é uma realidade em todas as unidades da federação, por vezes, existirão dois juízes lidando com os mesmo problemas estruturais de uma unidade, porque um cuida da execução da pena de um preso condenado definitivamente e outro, da legalidade da prisão provisória de outro - isso ocorre também com o Ministério Público e com a Defensoria Pública, que também possuem núcleos especializados. As unidades prisionais deveriam, em tese, realizar a divisão dos presos, para que eles os condenados definitivamente e os provisórios ficassem separados. Contudo, isso não acontece na realidade de nenhum estado federado. Portanto, necessário pensar em adequar a lei à realidade existente: presos provisórios e condenados definitivamente convivem e, por vezes, devem ter tratamento jurisdicional igual, p. e., quando houver uma demanda em relação às condições de habitabilidade de uma unidade prisional.

195 Lei Federal n. 7.210 de 11 de julho de 1984. 
uma área da prática e do conhecimento jurídicos, e, sim, um conjunto de meros atos administrativos. A LEP é criada com a finalidade de garantia de maiores e melhores controles na execução penal. Escolheu-se o controle judicial, que - se imaginava - daria conta de garantir os direitos dos presos no ordenamento jurídico. O texto aponta para a origem de um dos obstáculos para a efetividade da Lei (1988, p. 25).

\begin{abstract}
A finalidade da execução deve ser explicitada em lei para que sirva de orientação aos seus intérpretes e aplicadores. É evidente que a lei não pode fixar toda a atividade da execução. Mas do princípio decorre a previsão de uma intervenção judicial através de procedimento que assegure todas as garantias jurisdicionais: isto é, contraditório, ampla defesa, defesa técnica, possibilidade de recurso, sempre que haja passagem justificada de um degrau a outro no regime progressivo ou se questionem direitos dos presos reconhecidos nas Regras Mínimas da ONU. Observe-se que, tanto quanto no Direito Penal e no Direito Processual Penal, resta superar o âmbito das garantias puramente formais, procurando tornar real o princípio ideológico. (WIECKO, 1988, p. 25) (grifo meu)
\end{abstract}

A autora adverte, contudo, de que nada vale a legalidade formal se não traduzir o dia a dia da execução. Afirma que, para tanto, são necessárias garantias, apontando o controle jurisdicional de atos da execução como a resposta para concretizar os direitos garantidos nesse plano (1988, p. 69). Infelizmente, com o passar dos anos, o controle jurisdicional, e ainda outros controles por meio de outros órgãos estatais sobre o sistema prisional, não se demonstrou como uma resposta que dê conta dos suplícios impostos aos presos, como se pensava à época da promulgação da Constituição de 1988.

Ao longo do tempo, a LEP sofreu algumas alterações. A mais criticada delas, pelos teóricos da linha contra-hegemônica da área do direito penal, é a criação do regime disciplinar diferenciado, o RDD. Salo de Carvalho e Alexandre Wunderlich (2004, p. 384385), ao tratar da então inovação do regime disciplinar diferenciado imposta pelo Congresso Nacional, utilizam o conceito de "não-lugar" para descrever a Lei: algo projetado para conquista, não algo que se tenha, ou seja, algo inexistente. Continuam os autores:

(....) o recente texto delimita uma forma de execução da pena totalmente inédita, visto que consagra em Lei o suplício gótico vivido pelos condenados nos presídios brasileiros. Se antes ainda havia possibilidade de desqualificar a desumana realidade carcerária nacional invocando a LEP, com sua alteração, a tragédia é subsumida à Lei. Não nos referimos, logicamente, a eventual legitimidade que a Lei 10.792/03 estaria auferindo à péssima "qualidade de vida doméstica" imposta ao preso. Certamente 
nosso legislador não encontraria palavras para descrever a fétida realidade prisional; não teria coragem de redigir texto cujo conteúdo produzisse a adequação da Lei ao cotidiano de ostentação do sofrimento; não realizaria o ato de desvelar o gozo da "opinião publicada" ao ver seus excluídos penarem corporalmente. (CARVALHO \& WUNDERLICH, 2004, p. 384) (grifo meu)

Nessa passagem, resta evidente que o pressuposto da realidade é a do suplício. Quanto à previsão legal do RDD, chegam à conclusão de que o suplício, agora, estaria introjetado na Lei de Execuções Penais, que até ali vinha resistindo aos apelos populistas legiferantes. No outro ponto destacado, os autores ressaltam a discrepância entre a realidade e a Lei, chegando ao limite de afirmar que o legislador não encontraria palavras para descrever o que ocorre na prática das prisões brasileiras. Evidencia-se, portanto, o abismo entre a lei - no caso, a Lei de Execuções Penais - e a realidade vivida - ou sobrevivida - no sistema prisional brasileiro.

Apesar dessa alteração, houve outras que vieram na contramão do direito penal do inimigo. A mais recente trata da educação no sistema prisional, especificando as condições em que estão assegurados esses direitos às presas e aos presos ${ }^{196}$. Apesar do contexto do supercencarceramento e do direito penal máximo, a Lei de Execução Penal continua sendo um excelente instrumento de proteção das pessoas privadas de liberdade no Brasil.

Os órgãos da execução, de igual forma, só foram expandidos, fazendo com que constituam, atualmente, um grande conjunto de instituições que tem o dever de realizar o controle da execução penal. O Conselho Nacional de Política Criminal e Penitenciária, o Juízo da Execução, o Ministério Público, o Conselho Penitenciário, os Departamentos Penitenciários, o Patronato, o Conselho da Comunidade, a Defensoria Pública. Todos esses órgãos, adicionados os supracitados, fazem parte de um grande aparato de controle da execução penal. A maioria deles é estatal. Os ligados ao Sistema de Justiça, tais como o Poder Judiciário e o Ministério Público, possuem membros e corpo técnico muito bem remunerados e qualificados, além de boa estrutura para atuação. Fica-se com o questionamento: por que a LEP, então, não é cumprida?

A função desse item da dissertação não é investigar as razões pelas quais não se cumpre a Lei de Execução Penal, que, deve ser repisado, encontra-se em consonância com o direito internacional dos direitos humanos. Nesse ponto, busca-se pontualmente indicar a 
discrepância entre a legislação avançada e a riqueza das instituições e a miséria das e nas prisões brasileiras.

Ao se utilizarem de uma figura mitológica, Carvalho e Wunderlich (2004, p. 386) traduzem a realidade do cumprimento da pena nas prisões brasileiras. Tântalo foi condenado aos infernos, recebendo como sentença a eterna fome e sede; ele cumpria sua pena sempre que tentava se aproximar do lago, e a água lhe fugia, e sempre que tentava apanhar um fruto da árvore, que de repente se tornava inatingível. O endurecimento da legislação penal dos últimos anos vem nesse sentido: quando parece que há alívio, sobrevém um novo suplício, que se agrega aos já vividos pelas pessoas privadas de liberdade no país.

\subsection{O caso Aníbal Bruno}

O Presídio Professor Aníbal Bruno é uma unidade prisional do sistema prisional pernambucano, localizado no bairro do Curado, zona oeste da cidade de Recife, atualmente denominada de Complexo do Curado. Inaugurado em 06 de março de 1979, só entrou em funcionamento no dia 17 de dezembro do mesmo ano, data em que 164 detentos foram transferidos para seus espaços (ARRUDA, 2006, p. 36).

O presídio foi criado para presos que aguardavam julgamento, e não condenados em definitivo. A construção foi realizada nos moldes do "estilo pavilhonar", em que pavilhões isolados funcionavam como forma de separar núcleos que não deveriam se misturar. A obra foi inaugurada em um período de notória violência e criminalidade, em que o então governador Moura Cavalcanti "pediu ao Ministério da Justiça ${ }^{197}$ auxílio financeiro para suprir as necessidades do sistema prisional no Estado de Pernambuco" (SILVA, 2013, p. 3-4).

A origem do Presídio Professor Aníbal Bruno está no Centro de Classificação e Triagem do Recife, também chamado de Presídio do Recife. Esse local funcionava como um espaço para observação e triagem da pessoa privada de liberdade, em que uma equipe formada por assistentes sociais, médicos, psicólogos, psiquiatras, assessores jurídicos e educadores - traçava o perfil biopsicossocial do preso, a fim de encaminhá-lo para a unidade

197 Silva (2013, p. 4) evidencia o ineditismo da parceria entre governo federal e estadual, acrescentando que “A preocupação do governo era mostrar à população que o alto investimento, cerca de 55 milhões de cruzeiros valia a pena, pois era uma obra, a primeira do país, dessa categoria, planejada e construída dentro das recomendações básicas para uma programação penitenciária. Era o envolvimento do governo federal nas questões sociais do Estado (...)”. 
prisional mais adequada, dentro dos padrões estabelecidos pela política criminal do Estado de Pernambuco (SILVA, 2013, p. 5). O governador Marco Maciel, em 3 de setembro de 1980, por meio do Decreto n. 6.685, trocou o nome do Presídio do Recife para Presídio Professor Aníbal Bruno ${ }^{198}$.

Com os anos, a unidade prisional foi crescendo, assim como foi crescendo sua população carcerária - desde o início em maior número do que o de vagas - e, também, foram crescendo seus problemas. O Presídio Professor Aníbal Bruno figurou no ranking dos 10 piores presídios do notório relatório da CPI sobre o sistema carcerário da Câmara de Deputados de 2007. Em 2011, as organizações da sociedade civil, depois de anos de monitoramento da unidade - principalmente pelo SEMPRI e pela Pastoral Carcerária de Recife - decidem ingressar com uma demanda internacional para denunciar as violações de Direitos Humanos dentro do Presídio Professor Aníbal Bruno.

\subsubsection{A mobilização do direito internacional e o ingresso da demanda}

Em 3 de junho de 2011, a rede de organizações da sociedade civil - composta pela Pastoral Carcerária de Pernambuco, pelo Serviço Ecumênico de Militância nas Prisões (SEMPRI), pela Pastoral Carcerária Nacional, pela Justiça Global e pela Clínica Internacional de Direitos Humanos da Universidade de Harvard - solicita à Comissão Interamericana de Direitos Humanos medidas cautelares, com a finalidade de proteger a vida e a integridade pessoal dos presos no Presídio Professor Aníbal Bruno, em Recife. Em um documento de 40 páginas ${ }^{199}$, a rede de organizações denuncia "graves riscos à vida e integridade pessoal - entre mortes violentas, torturas, agressões e ameaças - sofridos pelos homens presos no Presídio Professor Aníbal Bruno (...), e as condições desumanas e degradantes por eles vividas", além de "proteger a vida e integridade pessoal dos presos,

198 Arruda (2006, p. 38) esclarece quem foi Aníbal Bruno: “O Professor Aníbal Bruno, jurista e médico, foi à personalidade escolhida para dar nome ao novo presídio, teve sua existência pautada em valores humanísticos. Filho de Palmares, cidade situada na mata sul do Estado de Pernambuco, nasceu em 06 de outubro de 1889, aos 16 anos concluiu ciências e letras no Ginásio Pernambucano. E, aos 23 anos concluiu o curso de direito na Faculdade de Direito do Recife. Aos 31 anos ingressa na primeira turma de Medicina de Pernambuco, concluindo o curso em 1925. Após 8 anos do exercício da medicina, abandona esse ofício para abraçar de vez a sua paixão: o magistério. Lecionando na Faculdade de Direito e na de Medicina."

199 O documento 1, chamado de "solicitação de medidas cautelares para proteger a vida e a integridade pessoal dos presos no Presídio Professor Aníbal Bruno" consiste na primeira solicitação da rede de organizações à CIDH. Disponível em: $<$ http://arquivoanibal.weebly.com/uploads/4/7/4/9/47496497/01 solicitacao-de-medidas-cautelares-presidioanibal-bruno-final-2011-06-03 --pub.pdf >. Acesso em: 20 out. 2015. 
funcionários e demais pessoas que ingressem na unidade" (p. 1).

Desde o início, portanto, o pedido dos peticionários ${ }^{200}$ consistia na outorga de medidas cautelares para proteção da vida e integridade pessoal - artigos $4^{\circ}$ e $5^{\circ}$ da CADH -, referente não só às pessoas privadas de liberdade na unidade, mas também em relação aos funcionários e demais pessoas que ingressem na unidade, que, em geral - e em grande número - são familiares de presos. Os peticionários afirmaram, na solicitação, que o presídio tinha contabilizado ao menos 52 mortes violentas desde 2008. Além desse dado, apontaram a superpopulação da unidade, naquela época com capacidade de 1.448 vagas, entretanto, com 4.042 presos.

No documento, relatam-se mortes, torturas, falta de assistência médica, ausência de investigação e/ou responsabilização por crimes e/ou faltas, necessidade de reforma estrutural dos prédios. Contudo, um dos relatos mais impressionantes - não porque não exista uma figura semelhante nos presídios do país, mas porque ainda não havia sido, assim, relatado para um órgão de proteção de direitos humanos - é a respeito dos "chaveiros". Em linhas gerais, o "chaveiro" é aquele preso que possui prerrogativas em relação aos demais, o que possui - ou possuiria, porque, às vezes, a depender da estrutura do pavilhão, não existem portas - a chave da cela dos demais presos. Segundo os peticionários, os “chaveiros" são expressão da "deformidade administrativa do sistema prisional no Estado de Pernambuco e fomentam a violência no espaço prisional com autorização do Estado". É o preso que substitui a figura de poder do agente penitenciário que se encontra ausente no dia a dia do cárcere ${ }^{201}$.

200 Designam-se as organizações da sociedade civil que advogam interesses de vítimas no âmbito da CIDH, no sistema de casos e petições, de peticionários, diferenciando-as das vítimas, até em função de prerrogativas existentes nos regulamentos da Comissão relativamente a um e a outro, que a vítima também pode levar à frente um caso no Sistema Interamericano de Direitos Humanos sozinha, se assim desejar, pois não há necessidade de se constituir advogado. Contudo, a fim de se estabelecer maior equilíbrio processual entre as partes, agora, no âmbito da CIDH, existe a figura do defensor interamericano, que poderá atuar, caso a vítima deseje, como seu advogado, levando à frente o procedimento perante a Comissão. A fim de implementar esse avanço no sentido do acesso à justiça de vítimas que não encontram apoio de organizações da sociedade civil, a Corte IDH - e agora a Comissão - desenvolveram cooperação técnica com a AIDEF - Associação Interamericana dos Defensores - que realiza, a depender do país e do sistema adotado, uma parceria com advogados ou defensores no âmbito nacional para a composição de um quadro de defensores interamericanos, de vários países da América. Quando uma vítima pede à CIDH ou à Corte IDH assessoramento jurídico de um defensor, existem uma série de nomes dispostos a trabalhar nesse sentido, capacitados para tanto. No Brasil, a AIDEF possui acordo de cooperação com a ANADEP, que realiza a seleção e capacitação dos defensores interamericanos brasileiros. Atualmente, os defensores interamericanos brasileiros são Antonio José Maffezoli Leite (DPE/SP) e Carlos Eduardo Barros da Silva (DPE/PA).

201 Os peticionários (p. 3-4) descrevem "chaveiros" desse modo: "Determinam quem pode ou não negociar drogas, aplicam castigos (torturas), encaminham para o castigo oficial, decidem quem deve ser encaminhado para os setores de atendimento médico, jurídico, psicossocial e outros setores de atendimento. Têm controle sobre o corpo e a vida de seus iguais, pois se um preso for assassinado dentro do pavilhão, outro que nem 
Quanto à metodologia, os peticionários esclarecem que a Pastoral Carcerária e o SEMPRI, durante longos anos, já vinham monitorando de forma rigorosa o Presídio Professor Aníbal Bruno, com visitas frequentes e, por certos períodos, com periodicidade semanal. Relatam que, em 20 de agosto e 20 de setembro de 2010, em conjunto com representantes da Pastoral Carcerária de Pernambuco, da Justiça Global e da Clínica Internacional de Direitos Humanos da Universidade de Harvard, realizaram visitas amplas ao Presídio Aníbal Bruno, que deram base para as informações contidas na solicitação das medidas cautelares. Ainda, ressaltam que houve coleta de informações junto a órgãos e instituições estatais - tanto em nível estadual, quanto federal -, por meio de visitas, diálogos com autoridades estaduais competentes e pesquisa de dados oficiais.

Ainda em relação ao método, fazem uma grave observação sobre a falta de transparência na unidade: relatam terem sido, em geral, bem recebidos pelo diretor e funcionários, com sua concordância para manter diálogo, mas com vigilância por policiais militares, agentes penitenciários ou "chaveiros" durante grande parte das visitas ${ }^{202}$. Acabam, nesse ponto, queixando-se do número restrito de presos a que tiveram acesso para conversar, especialmente se ao se comparar com o universo de mais de 4.000 pessoas. Os relatos das organizações evidenciam a restrição ao monitoramento realizado pela sociedade civil e, ao mesmo tempo, provas de ação ou omissão de agentes públicos em relação à proteção da vida e integridade pessoal dos presos naquela unidade.

Sobre as mortes, os peticionários relatam, de forma pormenorizada, as

sempre é o verdadeiro assassino muitas vezes é escolhido para assumir. Chaveiros cobram taxas de manutenção, que os presos normalmente chamam de pedágio, e caso a família de um preso não possa assumir esta dívida, ele apanha e é obrigado a sair do pavilhão. Chaveiros controlam as vendas das celas e dos espaços conhecidos como 'come quieto', onde os presos recebem suas visitas." (grifo meu)

202 Relato de alguns episódios envolvendo a falta de transparência na unidade (p. 5-6): “os peticionários foram barrados pela polícia militar ao tentar entrar no Pavilhão $G$ porque a guarda militar afirmou estar fazendo um 'baculejo', como é chamada a revista. Relatamos com mais detalhes abaixo como os policiais depois nos expulsaram da área dos Pavilhões G, H e I enquanto ameaçaram espancar um preso. Pouco depois, os peticionários receberam ordens para se retirar imediatamente do pavilhão 'Nova Disciplina' justamente enquanto entrevistavam um preso que relatava ter sido vítima de tortura e apresentava ferimentos graves causados por facão e comparáveis com ferimentos que havíamos visto em outro preso naquele dia. Curiosamente, o chaveiro do Pavilhão J, primeiro pavilhão visitado por nós naquele dia, estava nos esperando mais tarde na saída da Nova Disciplina. Em outro momento, logo após terem visitado a escola do presídio, os peticionários notaram que a guarda militar se aproximou e entrou no local. Tal fato foi um tanto estranho vez que não estava ocorrendo nenhuma aula ou evento na escola, estando presentes apenas poucos funcionários e professores, o que sugeriu que os peticionários estavam sendo seguidos e vigiados pela polícia militar. Como se pôde inferir dos relatos acima, também levando em conta que o chaveiro de cada pavilhão e seus assistentes acompanharam os peticionários durante toda a visita ao respectivo pavilhão, os peticionários praticamente não tiveram privacidade para conversar com os presos. (...) Os peticionários observaram, por exemplo, que em vários momentos os presos com quem conversaram elogiaram o trabalho do chaveiro na frente deste." (grifo meu) 
ocorrências de morte dentro do presídio, destacando as mortes violentas que, desde janeiro de 2008 até a data da solicitação das medidas cautelares ficavam em 52 mortes, dentro de um universo de 94 (mortes "naturais" e outras causas). Montam um quadro explicativo das mortes por ano (p. 8) e, nas páginas que se seguem, descrevem morte por morte violenta, com a finalidade de fornecer à Comissão Interamericana o maior número de informações o possível, na tentativa de facilitação da recomendação ao Estado brasileiro da investigação e responsabilização pelas violações.

Uma informação, nas próximas páginas, salta aos olhos: os peticionários, não raras as vezes - em verdade, na maioria delas - têm de recorrer a jornais e internet a fim de coletar dados sobre as mortes. Tal fato evidencia uma realidade que não é apenas da unidade em estudo ou de Pernambucano: existe uma dificuldade enorme em se obter informações, mesmo que de eventos tão significativos quanto à morte de pessoas sob custódia do Estado, na área da segurança pública no Brasil, em todos os seus Estados. A Lei de Acesso à Informação - Lei Federal n. 12.527 de 2011 - parece não se aplicar a esses casos específicos. O que dificulta ainda mais a obtenção de respostas para questões que envolvem segurança pública é que $a$ ) os órgãos são estaduais, não possuindo subordinação ou mesmo coordenação pelo Ministério da Justiça ${ }^{203}$; b) cada Estado possui uma estrutura particular de organização da sua segurança pública; c) são muitos os órgãos do Sistema de Justiça, também estaduais e, ainda, alguns federais, que atuam na área, fazendo com que as atribuições sejam compartimentadas, mas sem que alguma instituição realmente se responsabilize pela produção da informação; $d$ ) inexiste obrigação ${ }^{204}$ para a produção e disponibilização de dados e informações sobre segurança pública; e e) inexiste a centralização da informação no âmbito federal, para que as informações sejam transparentes e se possam traçar paralelos entre as situações vivenciadas nos diferentes Estados do país.

Logo após, os peticionários passam a relatar os casos de tortura que encontraram na unidade. Apontam a frequência do encontro com as práticas, mesmo que tenham tido acesso a um número reduzido de presos, assim como a conivência da administração do presídio. Ressaltam como torturadores preferenciais os policiais militares e os "chaveiros"; denunciam a existência de celas de castigo e isolamento e o uso de spray de pimenta e armas

203 O Conselho Nacional de Secretários de Segurança Pública não é uma experiência exitosa, tendo-se reunido muito pouco nos últimos anos. Portanto, não se chega a considerá-lo como uma expressão de coordenação dos órgãos estaduais, porquanto não possui efetividade.

204 Obrigação, aqui, em seu sentido forte: que gere responsabilização penal para o agente público responsável pela área, p. e., o Secretário de Justiça. 
de bala de borracha ${ }^{205}$. Apontam que os numerosos relatos de tortura e abusos recebidos pelos peticionários somente podem indicar a gravidade da situação enfrentada pelos presos. $\mathrm{Na}$ sequência, enumeram relatos de abuso e de tortura - espancamento, esfaqueamento, bater nas juntas das mãos com pedaço pesado de madeira, quebrar braço - para dar base à denúncia. Ao final desse ponto, os peticionários afirmam terem repassado as informações ao Ministério Público Estadual, que se quedou inerte ${ }^{206}$; advertem que sua pesquisa "confirma que casos registrados de tortura permanecem sem investigação e responsabilização".

Passam, daí, a tratar da ausência de assistência de saúde. Afirmam que o Pavilhão $\mathrm{S}$ era o local em que ficavam concentradas as pessoas que necessitavam de assistência de saúde, contudo, de que, ali, não havia espaço adequado para tanto. Relatam, para além da falta de estrutura, a falta de funcionários da área da saúde ${ }^{207}$. Chegam à

205 Segundo os peticionários (p. 18-19), "A prática de tortura é altamente frequente no Presídio Aníbal Bruno, o que é de conhecimento da administração do presídio. Os presos são alvo de abuso e violência nas mãos dos policiais militares cuja a função é garantir a segurança interna das prisões. Aos chaveiros também é delegada autoridade pela administração, e muitos atuam de maneira cruel. O Pavilhão R, também chamado de RRD (fazendo referência ao sistema de isolamento extremo previsto na lei do Regime Disciplinar Diferenciado), é um Pavilhão de controle oficial realizado indevidamente por um corpo de guarda da Polícia Militar de Pernambuco. Neste local existe uma cela chamada de espera, celas de castigo e celas de isolamento. A responsabilidade pelo espancamento e prática de tortura denunciados pelos presos nesse local seria, segundo eles, da polícia militar. Além de denúncias de torturas praticadas com uso de barrotes, chutes e outros, existem denúncias do uso de balas de borracha e spray de pimenta sem regulamentação oficial para o uso destas armas. $\mathrm{O}$ spray de pimenta tem sido acionado no rosto do preso para que ele não identifique o agente que comete agressões físicas. Agentes penitenciários fazem uso destas armas sem nenhuma restrição porque consideram como um método de tortura autorizado pelo Estado".

206 Assim narram os peticionários (p. 21): "Em agosto de 2010, um padre da Pastoral Carcerária apresentou ao [texto tachado], bem como a o promotor [texto tachado] um relatório sobre a tortura do preso com ferimentos de facão nas costas mencionado no parágrafo "b" e na Figura 1 acima. Semanas após fornecer tal prova, o padre entrou em contato com o promotor e descobriu que nenhuma investigação tinha sido iniciada até então. Como descrito no parágrafo "b" acima, os peticionários encontraram novamente com a vítima em setembro de 2010, após o encontro entre o padre e o promotor. A vítima informou aos peticionários que não tinha sido entrevistada por nenhuma autoridade e que seus ferimentos não tinham sido examinados por nenhum profissional do Instituto Médico Legal. Três dias após o segundo encontro com a vítima, em setembro de 2010, os peticionários perguntaram ao mesmo promotor [texto tachado] se ele havia iniciado uma investigação sobre o ocorrido. Ele alegou que sim, no entanto, este não pareceu ser o caso. Quando o promotor retirou o ofício original enviado pelo padre e fotografia de dentro de sua pasta, os peticionários observaram que não havia folha alguma anexada ao documento original indicando que algum procedimento teria sido aberto. $\mathbf{O}$ promotor, então, afirmou que a conversa com os peticionários o tinha lembrado de que precisava tratar do assunto." (grifo meu) Quanto ao texto tachado, foi uma escolha dos peticionários, agora representantes dos beneficiários perante a Corte IDH, tacharem os nomes e marcas particulares em fotos, que pudessem identificar pessoas, a fim de preservar sua privacidade e integridade, já que resolveram, por meio do uso de página na internet, abrir todos os documentos do caso.

207 Sobre a questão da saúde, os peticionários (p. 21-22) apontam que: "Muitos dos presos dormem no chão do corredor do pavilhão, em colchões extremamente finos, pois não há leitos suficientes para acomodar todos. Os presos que se encontram no pavilhão $\mathrm{S}$ estão em situação de completo abandono, praticamente sem nenhum acompanhamento médico ou mesmo medicamento. Durante as visitas ao presídio em agosto e setembro de 2010, os peticionários foram informados de que havia apenas 5 (cinco) médicos para cuidar dos aproximadamente 4.000 presos que havia no Aníbal Bruno na época. No dia da visita dos peticionários em setembro de 2010, não havia nenhum médico no local. Outro problema sério é a falta de agentes, carros e ambulâncias para encaminhar os presos ao hospital. Isto foi uma das principais reclamações dos presos quando 
conclusão, a partir da narrativa de um agente penitenciário, de que as mortes "naturais", já referidas, possuem conexão com a ausência de assistência de saúde, que pode ser apreendida a partir das condições - ou falta delas - encontradas. Na sequência, indicam uma série de casos de saúde que precisam de tratamento urgente, com pedido para o órgão estadual de saúde, de que não obtiveram resposta (p. 22-25).

Os peticionários começam, então, a tratar das condições de habitabilidade da unidade - celas com péssimas condições estruturais, superlotadas, sem iluminação suficiente, presos sem acesso regular a água potável, sem alimentação adequada, sem atendimento médico e sem condições mínimas de higiene e limpeza -, utilizando-se, para tanto, como parâmetro as Regras Mínimas para o Tratamento de Presos das Nações Unidas ${ }^{208}$ e o Conjunto de Princípios para a Proteção de Todas as Pessoas Submetidas a qualquer Forma de Detenção ou Prisão, também das Nações Unidas ${ }^{209}$. Em relação à normativa interamericana, apontam que tais fatos consubstanciam-se em violações à Convenção Americana - quanto à proteção da integridade pessoal, em seu artigo $5^{\circ}$ - assim como configuram a prática de tortura, de acordo com o artigo $2^{\circ}$ da Convenção Interamericana para Prevenir e Punir a Tortura.

Com base no artigo 25 do Regulamento da $\mathrm{CIDH}$, os peticionários alegam, diante dos fatos apresentados, a gravidade, a urgência, os danos irreparáveis às pessoas e a necessidade para a concessão das medidas.

Pedem, especificamente, que se adotem medidas para a garantia da vida e da integridade pessoal de todas as pessoas presas na unidade, assim como as pessoas que ali trabalham ou ingressam; garantia de atendimento de saúde adequado; garantia de redução da população carcerária; garantia de investigação dos crimes e abusos cometidos dentro da unidade; garantia do direito dos membros das entidades peticionárias para a realização de visitas de monitoramento; garantia de imediata capacitação e ampliação do quantitativo de agentes penitenciários lotados no presídio; e garantia de consulta com os peticionários sobre

da visita dos peticionários. Um dos agentes penitenciários com quem conversamos afirmou que há pelo menos uma morte 'natural' por mês. Dadas as condições descritas, não é difícil presumir que muitas destas mortes, se não a maioria, são causadas pela falta de cuidado médico apropriado. Importante salientar que os casos descritos a seguir não têm a pretensão de exaurir todos os casos de necessidade de assistência médica no Presídio Aníbal Bruno". (grifo meu)

208 As Regras Mínimas para o Tratamento de Presos das Nações Unidas foram adotadas pelo Primeiro Congresso das Nações Unidas sobre Prevenção do Delito e Tratamento do Delinquente, celebrado em Genebra em 1955, e aprovadas pelo Conselho Econômico e Social em suas resoluções 663C (XXIV) de 31 de julho de 1957 e 2076 (LXII) de 13 de maio de 1977. As Regras Mínimas encontram-se, há anos, em processo de debates e revisão.

209 Adotado pela Assembleia Geral da ONU em sua resolução 43/173, de 9 de dezembro de 1988. 
ações coordenadas no sentido de cumprimento das medidas cautelares.

Em 8, 14 e 18 de julho de 2011 210 , os peticionários encaminharam informações adicionais sobre a gravidade e urgência da situação no Presídio Aníbal Bruno, reportando novos casos de tortura, violência praticada por "chaveiros", rebelião com feridos por conta da ação da Batalhão de Choque da Polícia Militar e mortes de presos, no sentido de reiteração da solicitação das medidas cautelares.

\subsubsection{As medidas cautelares perante a Comissão Interamericana de Direitos Humanos}

Em 28 de junho de 2011, a CIDH emitiu manifestação ${ }^{211}$ no sentido de solicitar informação adicional sobre o caso às organizações e ao Estado. Houve notificação, portanto, do Estado brasileiro relativamente às 4 manifestações enviadas pelas organizações; contudo, o Estado brasileiro restou silente. Foi nesse contexto que se deu a adoção das medidas cautelares pela Comissão Interamericana.

Com a contundente e vastamente documentada manifestação das organizações da sociedade civil que, por 4 vezes, em menos de 2 meses, solicitaram e reiteraram a solicitação de medidas cautelares, a Comissão Interamericana de Direitos, em 4 de agosto de 2011, decidiu no sentido de adotar medidas urgentes em favor das pessoas privadas de liberdade no Presídio Professor Aníbal Bruno, no bojo da MC 199-11, assim determinando ao Estado brasileiro:

1. adotar todas as medidas necessárias para proteger a vida, integridade pessoal e saúde das pessoas privadas da liberdade no Presídio Professor Aníbal Bruno na cidade de Recife, Estado do Pernambuco;

2. adotar as medidas necessárias para aumentar o pessoal de segurança do Presídio Professor Aníbal Bruno e garantir que sejam os agentes das forças de segurança do Estado os encarregados das funções de segurança interna, eliminando o sistema dos chamados "chaveiros" e assegurando que não thes sejam conferidas às pessoas privadas da liberdade funções disciplinarias, de controle ou de segurança;

3. assegurar o provimento de uma atenção médica adequada aos beneficiários, oferecendo atendimento médico que permita a proteção da

210 Documentos disponíveis em <http://arquivoanibal.weebly.com/arquivo.html>. Acesso em: 20 out. 2015.

211 A CIDH, nessa oportunidade, ressaltou que "Igualmente, cabe-me informar-lhes que no dia de hoje, a Comissão remeteu uma solicitação de informações ao Estado em relação à situação em referência. As partes pertinentes dessa comunicação estabelecem: 'Em conformidade com o artigo 25(5) do Regulamento da Comissão, e sem prejulgar sobre a possível adoção de medidas cautelares, cabe-me solicitar a Vossa Excelência que tenha por bem enviar a esta Secretaria, no prazo de 10 dias, contados a partir do recebimento desta comunicação, as informações que considerar oportunas sobre a situação a que se referem os peticionários."' (grifo meu) 
vida e da saúde dos beneficiários;

4. adotar todas as medidas necessárias para evitar a transmissão de doenças contagiosas dentro do Presídio Professor Aníbal Bruno, inclusive através de uma redução substantiva da superpopulação das pessoas ali privadas de liberdade;

5. adotar estas medidas em consulta com os representantes dos beneficiários; e

6. informar sobre as ações adotadas a fim de diminuir a situação de superpopulação verificada no Presídio Professor Aníbal Bruno. (grifo meu)

O Estado brasileiro manifestou-se pela primeira vez em 25 de agosto de 2011, no sentido de adotar todas as medidas possíveis para a solução dos problemas apontados pela Comissão Interamericana de Direitos Humanos.

Em 10 de novembro, os representantes dos beneficiários entregaram à Comissão Interamericana o que chamaram de $1^{\mathrm{o}}$ Contrainforme ${ }^{212}$, em que enfrentaram os pontos trazidos pelo Estado brasileiro, chegando à conclusão de que a situação permaneceu a mesma, com o acréscimo de novos casos de tortura e outros abusos e, ainda, um incremento de população carcerária, que passou de 4.042 para 4.827 presos.

Em sua segunda manifestação, em 23 de fevereiro de 2012, o Estado brasileiro repisou sua manifestação no sentido realizar as mudanças apontadas, em acordo com as medidas cautelares adotadas pela Comissão.

Os representantes dos beneficiários, em seu $2^{\circ}$ Contrainforme ${ }^{213}$, datado de 26 de

212 As organizações, em resumo, manifestaram-se da seguinte maneira: “As medidas cautelares precisam ser mantidas. Três presos do Aníbal Bruno foram assassinados nos primeiros três meses de vigência das medidas cautelares que a Honorável Comissão Interamericana de Direitos Humanos (CIDH ou Comissão) emitiu no dia 4 de agosto de 2011 visando a proteção, pelo Estado brasileiro, da vida, integridade pessoal e saúde das pessoas privadas de liberdade naquele complexo prisional. Ademais, através de visitas ao Aníbal Bruno, análise de dados oficiais e reuniões com autoridades, documentamos 26 casos recentes de tortura e outros abusos ocorridos no presídio, muitos desses praticados por agentes estatais ou por presos oficialmente contratados para desempenhar funções de estado. As condições desumanas de habitação, a insalubridade generalizada e a falta de atendimento médico no Aníbal Bruno também permanecem. O Estado não cumpriu com a determinação da Comissão de diminuir, inclusive para fins de melhoras de saúde, a extrema superlotação carcerária do Aníbal Bruno. Quando solicitamos as medidas cautelares para a Comissão no início de junho de 2011, havia cerca de 4.042 presos no Aníbal Bruno. No dia $1^{\circ}$ de novembro, o Aníbal Bruno contava com 4.827 homens em espaço destinado para apenas 1.448." (grifo meu)

213 Com base em novas denúncias, a rede faz as seguintes solicitações à CIDH: "Com base no exposto, reiteramos a necessidade da Honorável Comissão dar continuidade às medidas cautelares 199-11 vigentes, dada a continuidade da situação de extrema gravidade, urgência e risco de danos irreparáveis a pessoas no Aníbal Bruno. Solicitamos que a Comissão considere a possibilidade de: 1) ampliar a aplicação das medida aos funcionários, visitantes e demais pessoas que ingressam no Aníbal Bruno, dado ao risco a essas pessoas, tal como demonstramos no presente contrainforme; e 2) acrescentar às atuais medidas cautelares, um pedido para que o Estado brasileiro adote todas as medidas necessárias para prevenir e mitigar o alto número de casos de prolongada detenção provisória, arbitrária, excessiva e/ou ilegal no Aníbal Bruno, inclusive combatendo a morosidade no sistema de justiça penal e aumentando significativamente a prestação de assistência jurídica tempestiva e célere nos casos de presos provisórios. Tal solicitação se embasa nos numerosos e extremamente graves, urgentes e irreparáveis danos a presos encarcerados por razões 
agosto de 2012, em face de novas denúncias de violações de direitos humanos no Presídio Professor Aníbal Bruno, solicitam a ampliação das medidas cautelares estender sua proteção “aos funcionários, visitantes e demais pessoas que ingressam no Aníbal Bruno”; o acréscimo às atuais medidas cautelares, no sentido de que o Estado brasileiro "adote todas as medidas necessárias para prevenir e mitigar o alto número de casos de prolongada detenção provisória, arbitrária, excessiva e/ou ilegal no Aníbal Bruno"; e o envio pela Comissão à Corte IDH de pedido de medidas provisórias.

A Comissão Interamericana de Direitos Humanos, em posse dessas informações e documentos, decidiu, em 2 de outubro de 2012, ampliar as medidas cautelares ${ }^{214}$ já concedidas, dentro do seguinte escopo:

(...) Em vista da informação referida, corresponde ampliar a vigência das medidas cautelares de referência a fim de cobrir também aos funcionários do centro penitenciário e aos visitantes, além de solicitar ao Governo de Sua Excelência tenha por bem informar à CIDH sobre o acerto de implementação realizado com os beneficiários e os peticionários. (grifo meu)

No mesmo 2 de outubro, a CIDH emitiu convocação para reunião de trabalho entre os representantes dos beneficiários e o Estado brasileiro a ser realizada em 3 de novembro de 2012, em Washington, no âmbito da $146^{\circ}$ Período de Sessões.

A fim de atualizar a Comissão sobre o Presídio, as organizações apresentaram, durante a reunião de trabalho, informações sobre sua situação à época ${ }^{215}$, com dados que descabidas, de forma inadequada ou por tempo indevido no Aníbal Bruno. Solicitamos ainda que a Comissão encaminhe à Corte Interamericana de Direitos Humanos um pedido de medidas provisórias nos termos das atuais medidas cautelares, mais os acréscimos acima solicitados." (grifo meu)

214 Nesse contexto, decidiu a Comissão Interamericana de Direitos Humanos pela ampliação das medidas cautelares no caso Aníbal Bruno: “A CIDH recebeu informação dos peticionários que indica que existiria o risco da situação de violência no Complexo Penal Professor Aníbal Bruno ultrapassar a capacidade dos funcionários que trabalham ali, deixando-os sujeitos ao risco de violência. Os peticionários indicam que pelo menos dois funcionários haviam sido feridos durante rebeliões e pelo menos um agente havia resultado falecido devido à violência na penitenciária. A respeito dos visitantes, em alguns dos motins, os atos de violência haviam supostamente ocorrido durante o horário de visitas. Aparentemente, os guardas de segurança haviam disparado balas de borracha de maneira indiscriminada."

215 A rede apresentou as seguintes informações sobre a atuação do Presídio Professor Aníbal Bruno: “Ao menos 14 homicídios (incluindo um em outubro de 2012) e seis mortes "naturais" (incluindo três em outubro de 2012) ocorreram no Presídio Aníbal Bruno desde a adoção de medidas cautelares pela Comissão Interamericana de Direitos Humanos para a proteção da vida, integridade pessoal e segurança dos presos da unidade há pouco mais de um ano, em 4 de agosto de 2011.1 Além destes homicídios e mortes no Aníbal Bruno, diversos novos casos de tortura, um número decrescente de agentes penitenciários em serviço, severas deficiências continuadas no sistema de saúde e um aumento na superlotação demonstram que os beneficiários das medidas cautelares MC 199-11 continuam enfrentando um risco de extrema gravidade e urgência de danos irreparáveis. A situação, portanto, justifica a manutenção das medidas cautelares e a solicitação de medidas provisórias à Corte Interamericana de Direitos Humanos. De fato, a situação no Aníbal 
apontavam o aumento da população carcerária e da continuidade de problemas de homicídio, violência, tortura, ausência de assistência de saúde e falta de agentes penitenciários com a finalidade de extinguir a figura do "chaveiro". Reiteraram o pedido feito anteriormente referente à questão da contratação de agentes penitenciários e extinção da figura do chaveiro ${ }^{216}$, contudo, agregaram as seguintes demandas: a) abolição imediata da revista íntima; b) estabelecimento de uma delegacia da Polícia Civil especializada para investigar os crimes ocorridos no sistema prisional de Pernambuco e, também, de uma forçatarefa independente para condução de investigação de atos de corrupção relativos à unidade; c) criação, por meio de lei, do comitê e mecanismo estaduais de prevenção à tortura, assim como a aprovação da lei federal criando o Mecanismo Nacional de Prevenção e Combate à Tortura; $d$ ) estabelecimento de uma intervenção de emergência na área médica (mutirão da saúde); e) garantia da apresentação imediata perante autoridade judicial de cada novo ingressante em situação de prisão provisória no Aníbal Bruno e garantia a defensor público; f) Suspensão da entrada de novos presos na unidade; g) Extinção da proibição do uso de câmeras pelos representantes dos beneficiários durante suas inspeções ao Aníbal Bruno e orientação para toda a equipe da unidade no sentido da cooperação com as organizações para o monitoramento da implementação das medidas cautelares.

O Estado brasileiro respondeu em 14 de novembro de 2012.

Em 13 de setembro de 2013, os representantes dos beneficiários remetem à Comissão Interamericana de Direitos Humanos seu $3^{\circ}$ Contrainforme, em que trazem, em resumo, as seguintes informações a) 35 novas denúncias de violência; b) 76 solicitações de atendimento à saúde no Aníbal Bruno; c) aumento do número de presos, agravando, ainda mais, o problema da superlotação da unidade (6.456 presos para 1.514 vagas); d) relatório do governo federal constatando a insuficiência da atuação do Estado ${ }^{217}$. A solicitação, ao

Bruno se deteriorou desde nosso último relatório em agosto de 2012 por ter o Estado aumentado a população da prisão de 5473 para 5827 nos últimos dois meses, agravando a ameaça de motins, violência, negligência na área de saúde e disseminação de doenças contagiosas no presídio com capacidade para 1513 presos." (grifo meu)

216 Reproduz-se, integralmente, o primeiro pedido das organizações em sede dessa manifestação: "Eliminar a figura do 'chaveiro' com segurança e contratar novos agentes penitenciários para reduzir a proporção entre agentes e presos (atualmente de mais de 100 para um por plantão) para 5:1 por plantão, alinhando-se com a Resolução 1, de 09 de março de 2009, do Conselho Nacional de Política Criminal e Penitenciária; [Medidas cautelares 1, 2, 3, 4]".

217 Referência ao Relatório de Inspeção confeccionado pela Ouvidoria do Sistema Penitenciário, Departamento Penitenciário Nacional, Ministério da Justiça da Relatório, de 26 de dezembro de 2012, produzido a partir de inspeção e audiência pública, realizados em novembro de 2012 em Recife, sobre o sistema prisional de Pernambuco. Em suas conclusões, a Ouvidora conclui que "[A]pesar dos esforços da SERES [Secretaria de Ressocialização], é necessário considerar que estes não foram suficientes para resolver as mazelas do sistema (...) [O] estado de Pernambuco ainda precisa melhorar significativamente a garantia dos 
final, é de que as medidas cautelares sejam mantidas.

Em função de comunicação da CIDH de 19 de setembro de 2013, que veiculava perguntas específicas ${ }^{218}$ para pronta resposta, o Estado brasileiro respondeu à Comissão em 28 de outubro de 2013. Em 26 de novembro de 2013, a Comissão Interamericana remete questionamento ao Estado brasileiro, especificamente sobre o resultado da reunião realizada em outubro com órgãos federais e estaduais, no que se convencionou denominar Fórum Permanente para o Acompanhamento das Medidas Cautelares relativas ao Presídio Aníbal Bruno. O Estado brasileiro manteve-se silente.

Em 18 de fevereiro de 2014, as organizações encaminharam à CIDH seu $4^{\circ}$ Contrainforme, em que trazem novas denúncias de violência, abuso e ausência estatal, concluindo com os seguintes pedidos: a) manutenção das medidas cautelares; b) ampliação das medidas para proteção da liberdade pessoal de alguns presos que colaboraram com os representantes, denunciando as violações sofridas; c) solicitação de medidas provisórias à Corte IDH. Os representantes apresentaram, ainda, por e-mail, novas denúncias de violações em 28 de março de 2014.

\subsubsection{As medidas provisórias perante a Corte Interamericana de Direitos Humanos}

Em 9 de abril de 2014, a Comissão Interamericana, com base no artigo 63.2 da $\mathrm{CADH}^{219}$ solicita à Corte IDH que ordene ao Estado brasileiro adotar imediatamente as

direitos humanos em suas unidades penais (...) [N]em todos os questionamentos realizados foram atendidos pelo estado de Pernambuco e (...) ainda persistem denúncias veementes de violação de direitos."

218 A CIDH fez as seguintes proposições: “1. Medidas adotadas para proteger a vida, integridade pessoal e saúde dos beneficiários, bem como as medidas tomadas para investigar as 35 denúncias de violência indicadas pelos representantes; 2. Medidas implementadas para aumentar o pessoal de segurança do Presídio Professor Aníbal Bruno e garantir que sejam os agentes das forças de segurança do Estado os encarregados das funções de segurança interna, eliminando o sistema dos chamados 'chaveiros' e assegurando que não seja conferido a pessoas privadas de liberdade funções disciplinares, de controle ou de segurança; 3. Ações adotadas para assegurar o provimento de atenção médica adequada aos beneficiários, oferecendo atendimento que permita proteger suas vidas e saúde, em particular a respeito das 76 solicitações de atendimento alegadas pelos representantes; 4. Medidas adotadas para evitar a transmissão de doenças contagiosas dentro do referido centro de detenção, inclusive através de uma redução substantiva da superlotação de pessoas privadas de liberdade; 5 . Procedimentos tomados para consultar os representantes dos beneficiários em relação à implementação das medidas cautelares; 6. Informar sobre as ações adotadas a fim de diminuir a situação da superlotação no Presídio Professor Aníbal Bruno, e concretamente qual seria o número de vagas comportadas e quantas pessoas estariam privadas de liberdade atualmente no estabelecimento penitenciário; e 7. Medidas adotadas para investigar as denúncias de exploração sexual de menores no interior do presídio em questão."

219 Art. 63.2 da CADH: "Em casos de extrema gravidade e urgência, e quando se fizer necessário evitar danos irreparáveis às pessoas, a Corte, nos assuntos de que estiver conhecendo, poderá tomar as medidas provisórias que considerar pertinentes. Se se tratar de assuntos que ainda não estiverem submetidos ao seu conhecimento, poderá atuar a pedido da Comissão.” 
medidas necessárias para proteção dos direitos à vida e à integridade pessoal dos indivíduos privados de liberdade no Centro Penitenciário Professor Aníbal Bruno. A Comissão centra seu pedido ${ }^{220}$ nos seguintes pontos: a) controle efetivo da unidade, com respeito aos direitos humanos das pessoas privadas de liberdade; b) identificação das causas da entrada de armas na unidade; c) eliminação da prática do "chaveiro"; d) eliminação dos altos índices de superpopulação; e) acesso aos serviços de saúde para casos graves; f) combate à propagação de doenças contagiosas; g) eliminação das inspeções vexatórias dos visitantes; e h) investigação e responsabilização os fatos denunciados, a fim de que não se repitam no futuro.

Ainda, ao final, a Comissão roga que a Corte atente para a necessidade de agentes penitenciários capacitados, em número suficiente e com os meios para o desempenho adequado de suas funções relativas à custódia das pessoas privadas de liberdade no Presídio Professor Aníbal Bruno. Ainda, a Comissão solicita que o "planejamento e a execução das medidas se leve a cabo com a participação dos solicitantes dos beneficiários", assim como que o Estado brasileiro envie periodicamente relatório sobre o andamento de sua execução.

A rede de organizações apresentou manifestação à Corte Interamericana de Direitos Humanos em 21 de maio de 2014, com denúncias de novas violações: 1 homicídio - em 12 de maio de 2014 - e 3 outras mortes - em março de 2014. Ressaltam ser ainda mais preocupante o fato de que, entre essas três mortes, duas terem sido de presos que já referidos no último contrainforme - de 18 de fevereiro de 2014. Um deles havia solicitado assistência médica e outro havia denunciado maus tratos, que teriam sido a causa para sua necessidade de atendimento hospitalar. Ou seja, o Sistema Interamericano, assim como o Estado brasileiro, já tinha conhecimento de suas necessidades, contudo, quedaram-se inertes,

220 O pedido integral da Comissão Interamericana à Corte IDH foi feito nos seguintes termos: "79. No parecer da Comissão, a prioridade no presente caso é a adoção de todas as medidas necessárias para garantir que não haja mais mortos ou feridos, e que as condições de segurança no centro penitenciário "Professor Aníbal Bruno" sejam adequadas, a fim de evitar novas situações de violência. especificamente, a Comissão solicita que se rogue ao Estado do Brasil que envide todos os esforços necessários, em sua condição especial de garante dos direitos das pessoas sob sua custódia, para: i) conseguir um controle efetivo do centro penitenciário, em estrito apego aos direitos humanos das pessoas privadas de liberdade; ii) identificar as causas que permitem o tráfico de armas no interior do centro penitenciário, e responder a elas de maneira efetiva; iii) eliminar a prática de "chaveiros"; iv) eliminar os altos índices de superlotação; v) assegurar o acesso de serviços de saúde a pessoas que sofrem de doenças graves; vi) evitar a propagação de doenças contagiosas entre os internos; vii) eliminar as inspeções vaginais e anais em detrimento dos visitantes bem como de qualquer outra medida que atente contra sua vida ou integridade pessoal; e viii) investigar de maneira diligente os fatos denunciados, a fim de punir as pessoas responsáveis, inclusive agentes penitenciários, e evitar que os fatos narrados se repitam no futuro." 
resultando na morte de duas pessoas sob sua custódia. Ao fim, reiteram a necessidade da outorga das medidas provisórias para a proteção e garantia do direito à vida e integridade pessoal das pessoas privadas de liberdade, assim como para pessoas que ingressem no Presídio Professor Aníbal Bruno.

A Corte Interamericana de Direitos Humanos emitiu, em 22 de maio de 2014, resolução em que requer que o Estado brasileiro adote, entre outras ${ }^{221}$,

(...) todas as medidas que sejam necessárias para proteger eficazmente a vida e a integridade pessoal de todas as pessoas privadas de liberdade no Complexo de Curado, assim como de qualquer pessoa que se encontre neste estabelecimento, incluindo os agentes penitenciários, funcionários e visitantes.

\section{A Corte Interamericana de Direitos Humanos roga que o Estado brasileiro assim}

haja, adotando as seguintes medidas:

(...) a) elaborar e implementar um plano de emergência em relação à atenção médica, em particular, aos reclusos portadores de doenças contagiosas, e tomar medidas para evitar a propagação destas doenças; $b$ ) elaborar e implementar um plano de urgência para reduzir a situação de superlotação e superpopulação no Complexo de Curado; c) eliminar a presença de armas de qualquer tipo dentro do Complexo de Curado; d) assegurar as condições de segurança e de respeito à vida e à integridade pessoal de todos os internos, funcionários e visitantes do Complexo de Curado, e e) eliminar a prática de revistas humilhantes que afetem a intimidade e a dignidade dos visitantes.

Os juízes da Corte entenderam configurada a "situação de extrema gravidade e urgência e de possível irreparabilidade de danos aos direitos à vida e à integridade pessoal dos internos desse centro", assim como "de seus funcionários e de outras pessoas que

221 "1. Requerer ao Estado que adote, de forma imediata, todas as medidas que sejam necessárias para proteger eficazmente a vida e a integridade pessoal de todas as pessoas privadas de liberdade no Complexo de Curado, assim como de qualquer pessoa que se encontre neste estabelecimento, incluindo os agentes penitenciários, funcionários e visitantes, nos termos do Considerando 20 desta Resolução. 2. Requerer ao Estado que, na medida do possível, mantenha os representantes dos beneficiários informados sobre as medidas adotadas para a implementar a presente medida provisória. 3. Requerer ao Estado que informe à Corte Interamericana de Direitos Humanos a cada três meses, contados a partir da notificação da presente Resolução, sobre as medidas provisórias adotadas em conformidade com esta decisão. 4. Solicitar aos representantes dos beneficiários que apresentem as observações que considerem pertinentes ao relatório requerido no ponto resolutivo anterior dentro de um prazo de quatro semanas, contado a partir do recebimento do referido relatório estatal. 5. Solicitar à Comissão Interamericana de Direitos Humanos que apresente as observações que considere pertinentes ao relatório estatal requerido no ponto resolutivo terceiro e às correspondentes observações dos representantes dos beneficiários dentro de um prazo de duas semanas, contado a partir da transmissão das referidas observações dos representantes. 6. Dispor que a Secretaria da Corte notifique a presente Resolução ao Estado, à Comissão Interamericana e aos representantes dos beneficiários.” 
ingressem ao mesmo", no mesmo sentido que já haviam compreendido os membros da CIDH. Ressaltam que os fatos apresentados concernentes ao desrespeito à vida e à integridade pessoal dos indivíduos privados de liberdade na unidade, na forma de "rebeliões, agressões entre internos e por parte de funcionários contra internos, ameaças de morte, assassinatos", ressaltando que todos são fatos reconhecidos pelo Estado brasileiro, e, ainda, "supostos atos de tortura e tratamentos cruéis, doenças contagiosas sem atendimento de saúde adequado", indicam risco de extrema intensidade, gerando enorme preocupação à Corte.

Ademais, observa a Corte Interamericana de Direitos Humanos que a superpopulação no Complexo do Curado persiste, "apesar da construção de um novo pavilhão e dos esforços para transferir centenas de internos que já não deveriam estar abrigados nesse estabelecimento." Ao tratar dos esforços estatais para lidar com as violações, a Corte observa que o Estado busca reformar e construir novos estabelecimentos de detenção, criar foros de debate e elaboração de propostas de melhorias, fomentar a cooperação entre os órgãos do governo estadual e federal e melhorar a gestão do sistema prisional como um todo. Contudo, a Corte IDH afirma que, apesar de tais esforços, a situação de risco é extremamente grave e urgente, assim como é de caráter irreparável o possível dano aos direitos da vida e da integridade pessoal a que essas pessoas estão expostas.

Nesse sentido, conclui o que se segue:

Como a Corte já afirmou em outras oportunidades, o Estado tem o dever de adotar as medidas necessárias para proteger e garantir o direito à vida e à integridade pessoal das pessoas privadas de liberdade e de se abster, sob qualquer circunstância, de atuar de maneira tal que se viole a vida e a integridade das mesmas. Neste sentido, as obrigações que o Estado deve inevitavelmente assumir em sua posição de garante incluem a adoção das medidas que possam favorecer a manutenção de um clima de respeito dos direitos humanos das pessoas privadas de liberdade entre si, evitar a presença de armas dentro dos estabelecimentos em poder dos internos, reduzir a superlotação, procurar as condições de detenção mínimas compatíveis com sua dignidade, e prover pessoal capacitado e em número suficiente para assegurar o adequado e efetivo controle, custódia e vigilância do centro penitenciário. Além disso, dadas as características dos centros de detenção, o Estado deve proteger os presos da violência que, na ausência de controle estatal, possa ocorrer entre os privados de liberdade. (grifo meu)

A Corte explicita, portanto, sua posição quanto à custódia das pessoas privadas 
de liberdade 222 , ao afirmar que o ente estatal encontra-se em uma "posição especial de garante com respeito às pessoas privadas de liberdade em razão de que as autoridades penitenciárias exercem um controle total sobre estas". Adverte, contudo que a adoção das presentes medidas "não prejulga a responsabilidade estatal pelos fatos informados" (p. 13).

O Estado brasileiro manifestou-se em 2 de outubro de 2014.

Os representantes dos beneficiários das medidas provisórias encaminharam seu primeiro relatório para a Corte IDH em 5 de novembro de 2014, com pedidos pela manutenção das atuais medidas provisórias e pela solicitação ao Estado brasileiro de informações detalhadas acerca da investigação das denúncias que deram origem às medidas provisórias. As organizações, contudo, apresentam uma série de denúncias e argumentos interessantes à Corte.

Em 20 de janeiro de 2015, os representantes dos beneficiários remetem mais informações à Corte IDH sobre violações de direitos humanos cometidas dentro do Presídio Aníbal Bruno, como uma rebelião iniciada no dia anterior no Complexo Prisional, com o resultado de duas pessoas mortas e 29 , feridas. Os representantes afirmam terem decidido enviar a comunicação fora do cronograma em razão da grave preocupação com a possibilidade de escalada de violência no futuro próximo, assim como em função da dificuldade de prestação de informação por parte das autoridades competentes. Alegam que, enquanto confeccionavam a manifestação, mais notícias de rebeliões, mortes e feridos.

Em 3 de fevereiro de 2015, a Corte IDH envia comunicação às partes, observando que o Estado brasileiro descumpriu o prazo para envio de relatório trimestral datado de 24 de novembro de 2014 -, nos termos da resolução que adota as medidas provisórias, à Corte. Solicita-se ao Estado brasileiro que apresente o mais rápido possível o relatório, e que esse esclareça, inclusive, as denúncias trazidas pelas organizações na sua manifestação de 20 de janeiro de 2015.

O Estado brasileiro manifestou-se em 4 de fevereiro de 2015.

Em 28 de setembro de 2015, as organizações da sociedade civil e o Estado

222 Continua a Corte Interamericana de Direitos Humanos: “Adicionalmente, é oportuno recordar que o artigo 1.1 da Convenção estabelece as obrigações gerais que têm os Estados Parte de respeitar os direitos e liberdades nela reconhecidos e de garantir seu livre e pleno exercício a toda pessoa que esteja sujeita à sua jurisdição, as quais se impõem não somente em relação ao poder do Estado, mas também em relação a atuações de terceiros particulares. Esta Corte considerou que o Estado se encontra em uma posição especial de garante com respeito às pessoas privadas de liberdade em razão de que as autoridades penitenciárias exercem um controle total sobre estas. Além disso, a Corte afirmou que, independentemente da existência de medidas provisórias específicas, o Estado se encontra especialmente obrigado a garantir os direitos das pessoas em circunstâncias de privação de liberdade." 
brasileiro participaram de uma audiência pública perante a Corte Interamericana de Direitos Humanos. Na oportunidade, os representantes dos beneficiários apresentaram uma lista, em que se encontram compiladas mais de 500 denúncias de violações de direitos humanos, consubstanciadas em violências dos mais variados tipos, tais como mortes, agressões físicas, torturas e estupros.

Logo após, a Corte emitiu nova resolução, de 7 de outubro de 2015, em que determina o seguinte:

1. Requerer ao Estado que continue adotando, de forma imediata, todas as medidas e sejam necessárias para proteger eficazmente a vida e a integridade pessoal de todas as pessoas privadas de liberdade no Complexo de Curado, bem como de qualquer pessoa que se encontre neste estabelecimento, incluindo os agentes penitenciários, funcionários e visitantes, nos termos dos Considerandos 9, 15, 16, 20, 24 a 27, 33 e 36 a 38 da presente Resolução. 2. Requerer ao Estado que mantenha os representantes dos beneficiários informados sobre as medidas adotadas para cumprir as presentes medidas provisórias e que lhes facilite o acesso amplo, com o exclusivo propósito de acompanhar e documentar de forma confiável a implementação das presentes medidas. 3. Requerer ao Estado que informe à Corte Interamericana de Direitos Humanos a cada três meses, contados a partir da notificação da presente Resolução, sobre a implementação das medidas provisórias adotadas em conformidade com esta decisão e seus efeitos. 4. Solicitar aos representantes dos beneficiários que apresentem as observações que considerem pertinentes ao relatório requerido no ponto resolutivo anterior dentro de um prazo de quatro semanas, contado a partir do recebimento do referido relatório estatal. 5. Solicitar à Comissão Interamericana de Direitos Humanos que apresente as observações que considere pertinentes ao relatório estatal requerido no ponto resolutivo terceiro e às correspondentes observações dos representantes dos beneficiários dentro de um prazo de duas semanas, contado a partir da transmissão das referidas observações dos representantes. 6. Dispor que a Secretaria da Corte notifique a presente Resolução ao Estado, à Comissão Interamericana e aos representantes dos beneficiários.

Quanto aos termos assinalados no ponto 1, referente à garantia dos direitos à vida e à integridade pessoal dos indivíduos privados de liberdade no Complexo do Curado, a Corte demonstrou preocupação especificamente com os seguintes temas: a) combate às doenças contagiosas, como HIV e tuberculose, com especial atenção a pessoas que se encontram em condição de vulnerabilidade, tais como pessoas com deficiência ${ }^{223}$; b) redução

223 "9. Particularmente em relação aos casos de doenças contagiosas, a Corte ressalta que "[a] infecção [de tuberculose e HIV] em centros penitenciários representa, além disso, um sério problema de saúde pela alta transmissão de ambas as doenças. A progressiva deterioração da imunidade nos indivíduos infectados pelo HIV, lhes predispõe a que contraiam uma série de infecções oportunistas, entre elas a [tuberculose]. É em razão 


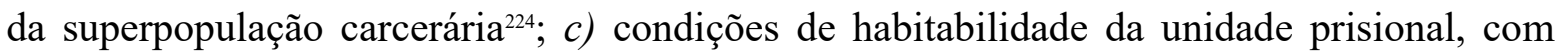
vistas à melhoria das condições de ventilação, luz natural, local para repouso, higiene, tempo fora do cárcere, ao ar livre, trabalho, entre outros ${ }^{225}$; d) revistas periódicas realizados no Complexo, a fim de controlar a manipulação de armas, drogas, bebidas e celulares pelos $\operatorname{presos}^{226}$; e) controle da segurança da unidade pelo Estado, com a consequente extinção da prática dos chaveiros ${ }^{227}$; f) condições para o monitoramento das medidas pelas organizações

disso que o controle da [tuberculose] nestes locais não pode ser abordado sem levar em consideração a prevenção e o controle do HIV". Portanto, o Estado deve tomar medidas urgentes para garantir a atenção médica adequada às pessoas doentes e também garantir que os demais internos e pessoas presentes nesse centro penitenciário não sejam contagiados. Em concreto, o Estado deve adotar um enfoque preventivo, de acordo com as necessidades particulares de saúde das pessoas privadas de liberdade e de grupos de alto risco ou vulneráveis, entre eles as pessoas com deficiência, portadores de tuberculose, HIV e outras doenças contagiosas." (grifo meu)

224 "15. A esse respeito, a Corte recorda que, em relação às condições das instalações nas quais se encontram pessoas privadas de liberdade, manter uma pessoa detida em condições de superlotação, com falta de ventilação e luz natural, sem leito para o repouso ou condições adequadas de higiene, em isolamento e incomunicação ou com restrições indevidas ao regime de visitas constitui uma violação à integridade pessoal. Portanto, é imprescindível que o Estado tome medidas concretas e com a máxima prioridade para reduzir a situação de superlotação e superpopulação de mais de $380 \%$ no Complexo Penitenciário de Curado.” (grifo meu)

225 "16. Ao implementar as medidas para redução da superlotação, o Estado deve ter presente que 'A capacidade de alojamento dos centros de privação de liberdade deverá ser formulada tendo em consideração critérios como: o espaço real disponível por recluso; a ventilação; a iluminação; o acesso aos serviços sanitários; o número de horas que os internos passam encerrados em suas celas ou dormitórios; o número de horas que estes passam ao ar livre; e as possibilidades que tenham de fazer exercício físico, trabalhar, entre outras atividades. Entretanto, a capacidade real de alojamento é a quantidade de espaço com que conta cada interno na cela na que é mantido encerrado. A medida deste espaço resulta da divisão da área total do dormitório ou cela entre o número de seus ocupantes. Neste sentido, como mínimo, cada interno deve contar com espaço suficiente para dormir deitado, para caminhar livremente dentro da cela ou dormitório, e para acomodar seus objetos pessoais' (Comissão Interamericana de Direitos Humanos, Relatório sobre os direitos humanos das pessoas privadas de liberdade nas Américas, 2011, par. 465)". (grifo meu)

226 "20. Em sua Resolução de 22 de maio de 2014, a Corte destacou que o Estado devia assegurar que as revistas fossem realizadas correta e periodicamente, destinadas à prevenção da violência e à eliminação do risco, em função de um adequado e efetivo controle no interior dos pavilhões por parte da autoridade penitenciária, e que os resultados destas revistas fossem devida e oportunamente comunicados às autoridades competentes. A esse respeito, o Estado informou sobre os resultados das revistas realizadas e sobre algumas medidas tomadas para evitar a entrada de armas, outros objetos ilegais e drogas no Complexo Penitenciário de Curado. Porém, a própria informação apresentada pelo Estado demonstra a completa falta de eficácia das medidas adotadas até o momento, pois mais de 16 meses depois da adoção das medidas provisórias no presente assunto, continuam sendo apreendidos centenas de armas, drogas de vários tipos, centenas de litros bebida alcoólica, centenas de celulares, entre outros. A Corte expressa sua grande preocupação com a continuação da presença de armas e o risco gerado por essa situação à integridade pessoal e à vida das pessoas presentes no Complexo de Curado, tanto internos como funcionários, agentes de segurança e visitantes. Ademais, a Corte considera imperativo que o Estado investigue de maneira diligente as denúncias de corrupção e comércio de armas por parte de funcionários e internos e que informe o Tribunal a esse respeito." (grifo meu)

227 "26. É imperativo que o Estado exerça o controle efetivo dos centros penitenciários. O anterior implica ser capaz de manter a ordem e a segurança no interior das prisões. O Estado deve ser capaz de garantir a todo momento a segurança dos presos, seus familiares, dos visitantes e das pessoas que trabalham nos centros penitenciários. Não é admissível sob nenhuma circunstância que as autoridades penitenciárias se limitem à vigilância externa ou perimetral, e deixem o interior das instalações nas mãos dos presos. Quando isso 
da sociedade civil, representantes dos beneficiários ${ }^{228}$; e $g$ ) proteção especial a pessoas com deficiência e $\mathrm{LGBT}^{229}$.

Em 18 de novembro de 2015, a Corte IDH emitiu nova resolução, que amplia as medidas provisória, no sentido da proteção da vida e integridade pessoal de Wilma Melo, representante dos beneficiários e membro do SEMPRI - Serviço Ecumênico de Militância nas Prisões. A Corte, a partir de comunicação remetida pelas organizações em 12 de novembro de 2015 , resolveu o que se segue:

\begin{abstract}
1. Ampliar as medidas provisórias emitidas sobre o presente assunto, de tal forma que o Estado adote as medidas necessárias para proteger a vida e a integridade pessoal da senhora Wilma Melo. 2. Reiterar ao Estado que continue adotando de forma imediata as medidas que sejam necessárias para proteger eficazmente a vida e a integridade pessoal das pessoas privadas de liberdade no Complexo de Curado, bem como de qualquer pessoa que se encontre no referido estabelecimento, incluindo os agentes penitenciários, funcionários e visitantes, nos termos da Resolução de 7 de outubro de 2015. 3. Requerer ao Estado que mantenha os
\end{abstract}

ocorre, o Estado coloca os presos em uma situação permanente de risco, expondo-os à violência carcerária e aos abusos de outros internos mais poderosos ou de grupos criminosos que atuam nestes recintos."

228 "33. Por outro lado, os representantes informaram à Corte em 18 de maio de 2015 sobre a proibição de entrada no Complexo de Curado com máquinas fotográficas e de vídeo. Além disso, em duas oportunidades posteriores, o Secretário de Justiça e Direitos Humanos de Pernambuco teria mantido esta proibição. $\mathrm{O}$ anterior dificultaria o monitoramento de violações de direitos humanos, em particular de alegados atos de tortura, ocorridos nesse centro carcerário." (grifo meu) A Corte continua, de maneira mais enfática, a se manifestar nesse sentido: "38. Finalmente, a Corte lamenta a imposição da restrição à entrada de máquinas fotográficas imposta aos representantes dos beneficiários por parte do Estado, em virtude de que isto constituiu uma interferência na capacidade de monitorar a implementação das medidas provisórias e na possibilidade de documentar eventuais graves violações de direitos humanos ocorridas no Complexo de Curado. Além disso, diante da informação do Estado do Brasil de que a referida restrição estaria baseada no Decreto n. 41.448, aprovado em 29 de janeiro de 2015, com vigência de 180 dias, a Corte entende que esta restrição expirou em 28 de julho de 2015 e, portanto, não estaria vigente. Por outro lado, a Corte avalia a informação apresentada pelo Brasil sobre a implementação em todo o território nacional, e também no Estado de Pernambuco, da Resolução n. 1, de 7 de fevereiro de 2013, do Conselho Nacional de Política Criminal e Penitenciária, a qual explicitamente permite o uso de meios audiovisuais e fotográficos por parte dos órgãos de execução da pena, bem como por entidades estatais e da sociedade civil de fiscalização do sistema penitenciário e defensores de direitos humanos, com a finalidade de elaborar relatórios. Em razão do anterior, a Corte não observa razões que justifiquem a proibição de entrada de meios fotográficos e audiovisuais por parte das organizações representantes dos beneficiários das presentes medidas provisórias. Finalmente, em relação à possível utilização de imagens internas do Complexo de Curado em programas sensacionalistas, a Corte observa que não recebeu informação concreta que indique que os representantes sejam responsáveis pela divulgação indevida dos casos documentados durante suas visitas de monitoramento."

229 "37. Sobre a situação em particular de pessoas com deficiência e pessoas LGBT, a Corte faz notar o dever de proteção do Estado diante de situações conhecidas de discriminação e risco de grupos em situação de vulnerabilidade. Nesse sentido, o Estado tem a obrigação de tomar todas as medidas disponíveis para proteger e garantir o gozo do direito à vida e à integridade pessoal das pessoas sob sua custódia. O anterior adquire particular urgência quando o Estado tem conhecimento de situações violatórias à integridade pessoal destas pessoas. A Corte toma nota do indicado pelo Estado sobre a criação de um espaço de convivência especial para pessoas LGBT, e espera que o Estado apresente informação concreta e detalhada em seus próximos relatórios sobre este ponto em particular." (grifo meu) 
representantes dos beneficiários informados sobre as medidas adotadas para cumprir com as medidas provisórias ordenadas e que coordene com a senhora Melo as medidas de proteção a seu favor. 4. Requerer ao Estado que, em seu próximo relatório à Corte Interamericana de Direitos Humanos disposto na Resolução de 7 de outubro de 2015, inclua informações sobre a implementação das medidas provisórias adotadas de conformidade com esta decisão e seus respectivos efeitos. 5. Solicitar aos representantes dos beneficiários que apresentem as observações que considerem pertinentes ao relatório requerido no ponto resolutivo anterior dentro de um prazo de quatro semanas, contado a partir do recebimento do referido relatório estatal. 6. Solicitar à Comissão Interamericana de Direitos Humanos que apresente as observações que considere pertinentes ao relatório estatal requerido no terceiro ponto resolutivo e às correspondentes observações dos representantes dos beneficiários dentro de um prazo de duas semanas, contado a partir da transmissão das referidas observações dos representantes. 7. Dispor que, de conformidade com artigo 27.8 do seu Regulamento, e prévio consentimento e coordenação com a República Federativa do Brasil, uma delegação da Corte Interamericana realize uma visita ao Complexo Penitenciário do Curado e ao estado de Pernambuco, no Brasil, com a maior brevidade possível, com o fim de obter, de forma direta, informação pertinente das partes para monitorar o cumprimento das medidas provisórias. 8. Dispor que a Secretaria da Corte notifique a presente Resolução ao Estado, à Comissão Interamericana e aos representantes dos beneficiários. (grifo meu)

Ademais, importante observar a severidade com que a Corte Interamericana de Direitos Humanos avalia a situação, ao solicitar uma visita ao Complexo do Curado e ao Estado de Pernambuco com a maior brevidade possível.

O caminho procedimental trilhado pela rede de organizações da sociedade civil restou demonstrado, primeiramente enquanto representante dos beneficiários de medidas cautelares perante a Comissão Interamericana de Direitos Humanos e, após, de medidas provisórias perante a Corte Interamericana de Direitos Humanos. O esforço, a partir de agora, será justamente aprofundar a busca pela perspectiva da sociedade civil sobre esse processo de mobilização transnacional do direito junto ao Sistema Interamericano de Direitos Humanos. 


\section{CAPÍTULO 3 - A PERSPECTIVA DAS ORGANIZAÇÕES DA SOCIEDADE CIVIL}

A rede da sociedade civil que se agrupou em torno dos problemas do Presídio Professor Aníbal Bruno começou a ser formada em 2010, por meio de contatos entre os representantes das organizações. Desde os anos noventa, o Serviço Ecumênico de Militância nas Prisões (SEMPRI) e a Pastoral Carcerária de Recife monitoravam periodicamente o sistema prisional de Pernambuco, sem, contudo, realizar ações conjuntas para além das inspeções e eventuais encaminhamentos de denúncias e pedidos individuais de presos que necessitavam, pontualmente, de seu auxílio na unidade. Com o passar dos anos, a experiência foi se acumulando, e os representantes das organizações criaram laços de confiança entre si, com os presos, familiares e agentes estatais.

Um olhar de fora - Pastoral Carcerária Nacional, Justiça Global e Clínica de Direitos Humanos da Universidade de Harvard - propôs uma nova fase para o trabalho de proteção e defesa dos direitos humanos nesse contexto: o Aníbal Bruno foi escolhido como a unidade paradigmática do sistema prisional pernambucano e brasileiro para ser levado ao sistema internacional de proteção dos direitos humanos. Ao pensar em uma ação de litigância estratégica internacional, aqueles que olhavam de fora - no caso, de longe procuraram aqueles que estavam dentro da realidade e, a partir desse primeiro contato, começaram uma articulação que foi se modificando. Foram, aos poucos, conhecendo-se, testando-se, desenvolvendo laços de afeto e formas de atuarem juntos pelos direitos humanos das pessoas privadas de liberdade no Presídio Professor Aníbal Bruno. O olhar de fora juntou-se com o olhar de dentro, e, dessa composição de olhares, nasceu uma parceria que se encontra em pleno vigor, após mais de cinco anos de atuação conjunta, e com novos espaços e ideias a serem exploradas no futuro.

A expectativa que eu tinha como pesquisadora era de encontrar uma divisão de trabalho segmentada, organizada e delimitada de acordo com os planos local, nacional e global, assim como com a expertise de cada organização específica. Surpreendentemente, a horizontalidade da rede que foi criada é um estímulo para se pensar em formas contrahegemônicas de trabalho em direitos humanos. Percebi que não apenas a demanda referente a violações de direitos humanos - as violações no Presídio Professor Aníbal Bruno - e o instrumento utilizado - as medidas cautelares que se tornaram provisórias na Corte IDH são o foco do trabalho da rede de organizações, mas, também, o processo em si de formação 
e manutenção sustentada de uma ação coletiva transnacional.

Com o objetivo de compreender melhor de que forma se constitui essa ação coletiva transnacional, fez-se necessário o uso das entrevistas para a coleta de dados junto às organizações. Isso porque a pergunta que rege a presente dissertação, qual seja, como as organizações percebem sua experiência num litígio internacional como o referido, seu alcance e limites, apenas pode ser respondida ao se ouvirem os representantes das organizações, que vivem o dia a dia do procedimento. Exploram-se algumas ideias, argumentos e sensações surgidas em duas entrevistas realizadas em outubro de 2015, com Eduardo Baker e Natália Damazio - representantes da Justiça Global ${ }^{230}$ - e com Wilma Melo - representante do SEMPRI ${ }^{231}$. As outras organizações - Pastoral Carcerária e Clínica de Direitos Humanos da Universidade de Harvard - não estavam disponíveis para a realização de entrevistas ${ }^{232}$. Contudo, o caráter diversificado das organizações apresentadas no trabalho dá consistência às informações que serão debatidas. O SEMPRI situa-se em Recife, Pernambuco, atua de forma local e possui foco nas questões sobre sistema prisional pernambucano, centrando-se em seu controle e monitoramento ${ }^{233}$. Já a Justiça Global situa-se no Rio de Janeiro, atua nacional e internacionalmente - mais especificamente em litigância estratégica no Sistema Interamericano de Direitos Humanos - e possui foco diversificado de atuação, trabalhando com vários temas na área de proteção a direitos humanos ${ }^{234}$. As entrevistas foram experiências muito ricas. O achado mais impressionante foi o debate

230 Entrevista realizada em por skype no dia 6 de outubro de 2015. Natália Damazio somente participou da entrevista por um curto espaço de tempo, em função de outros compromissos que tinha na organização; em decorrência disso, ver-se-á poucas manifestações feitas por ela.

231 Entrevista realizada em por skype no dia 9 de outubro de 2015.

232 As organizações estavam muito atarefadas no segundo semestre desse ano, especialmente em função da audiência pública realizada na Corte IDH em setembro e das audiências temáticas realizadas em outubro e novembro junto à Comissão Interamericana de Direitos Humanos.

233 Nas palavras de Wilma Melo: “O SEMPRI nasce de uma necessidade específica para trabalhar questões básicas do sistema prisional. Em 91, 92 eu já estava enquanto familiar de preso dentro das prisões. E já fazia denúncias. E aí foi quando conheci uma comissão carcerária aqui que o GAJOP fundou. Então foi Ronidalva (de Andrade Melo) que estava à frente dessa comissão com outras pessoas, mas ela, na verdade, era quem mais se doava. Era uma socióloga da Fundação Joaquim Nabuco. Ela que compreendia melhor as questões dos laços afetivos dos familiares de presos. Fui convidada e participei por algum tempo, mas continuei a fazer as denúncias. Em 97, ela conversou comigo, um grupo da Pastoral Carcerária também conversou comigo e a gente fundou o SEMPRI, o Serviço Ecumênico de Militância nas Prisões. A militância é coisa mais forte, é a coisa de maior doação, na perspectiva mais ativista, essa militância é muito forte, quando a gente cria o nome é muito forte. Militância e compromisso tá colocado. Eu gosto muito dessa militância. E eu não abandonei essa militância. SEMPRI nasce com essa perspectiva da luta pelos direitos humanos na prisão." (grifo meu)

234 A Justiça Global atua com a promoção e defesa dos direitos humanos nas áreas de acesso à justiça; defensoras e defensores de direitos humanos; direitos econômicos, sociais e culturais; e segurança pública e violência institucional. Informações disponíveis em <http://global.org.br/programas/>, acesso em outubro de 2015 . 
interno e o uso da expressão coalizão como forma de autodenominação por parte da rede de organizações. Outro achado interessante é que os entrevistados não identificam em qualquer instituição doméstica do Sistema de Justiça as funções ou o perfil da CIDH. Quando perguntados sobre o Ministério Público - comparação que normalmente se faz nas faculdades de direito quando se estuda o caráter quase-judicial da $\mathrm{CIDH}-$, ambos os entrevistados foram enfáticos em dizer que não havia similaridade alguma. Quanto à escolha pelo SIDH em detrimento das Nações Unidas, apareceram elementos interessantes, como especificidade da CIDH e da Corte IDH, a própria existência da Corte IDH, a existência de resposta, mesmo que tímida, do Estado brasileiro junto ao SIDH, a proximidade com a OEA e não com as Nações Unidas, entre outros. Questões que nesta pesquisa se pressupunha ter alguma relevância, como por exemplo, o debate sobre o não esgotamento dos recursos internos, foram praticamente ignoradas. Insisti em saber como havia sido a formação da rede, ao que, consensualmente, a resposta foi que a maioria das organizações já são parceiras há anos e possuíam confiança uma no trabalho da outra, o que resume a formação da rede na visão dos entrevistados.

O capítulo está disposto em três partes. A primeira abarca as manifestações e reflexões sobre o começo da parceria das organizações da sociedade civil e seu caminho para a construção de uma coalizão. A segunda agrega aquelas que se referem ao processo de internacionalização da demanda, com os temas da persistência mesmo em face aos obstáculos encontrados. A terceira indica as respostas que se conectam com o tema das oportunidades políticas, que num primeiro momento foi pensado apenas em relação ao Sistema ONU, havendo, contudo, uma expansão dessa proposição.

\subsection{Da parceria à coalizão}

\subsubsection{A escolha do Presídio Professor Aníbal Bruno}

\section{"Qualquer coisa de ruim que você possa imaginar de cadeia tem ou já teve no Aníbal Bruno" Eduardo Baker, Justiça Global}

Quanto às razões para a escolha do Presídio Professor Aníbal Bruno como objeto da demanda, a resposta foi um "simplesmente é". Para as organizações, havia um consenso 
implícito de que a unidade deveria ser escolhida como caso emblemático para lidar com questões de violações de direitos humanos no sistema prisional pernambucano, fazendo a ponte para a discussão sobre o sistema prisional brasileiro. Quando perguntei pelos critérios utilizados para a escolha do Aníbal Bruno, Eduardo Baker respondeu-me da seguinte forma:

\begin{abstract}
No caso de Pernambuco, o Aníbal simplesmente é. Que nem o Urso Branco em Rondônia. É a unidade com mais gente, boa parte do contingente prisional tá lá. É uma unidade para presos provisórios, então todo mundo meio que passa por ali. Quem vai fazer audiência na capital passa por ali. É a grande unidade de Pernambuco. É grande também porque tem muito mais gente do que vaga. São mil e oitocentas vagas e sete mil pessoas. Era isso. A experiência que a gente tem tido com o Aníbal é que todas as contradições e violências do sistema prisional estão ali, de alguma forma. Então você vê tudo lá. O Urso Branco também tinha, mas em menor grau. Então é a corrupção, tortura por preso, tortura por agente, morte por preso, morte por agente, falta de acesso à saúde, falta de acesso à defensoria e ao sistema de justiça de maneira geral, qualquer coisa de ruim que você possa imaginar de cadeia tem ou já teve no Aníbal Bruno. Construção improvisada. Tá tudo lá. É interessante nesse sentido, né, mórbido da palavra talvez, como raio $\mathbf{x}$ do sistema prisional brasileiro. Superlotação. Tá tudo lá. (grifo meu)
\end{abstract}

Na perspectiva de Wilma Melo, do SEMPRI, as violações, o número de morte, tudo o que estava acontecendo naquele momento - em 2010 - indicava que o Presídio Professor Aníbal Bruno deveria ser escolhido para ser o representante da realidade prisional do Estado de Pernambuco ${ }^{235}$.

\title{
3.1.2. A escolha de um caso emblemático para debater um problema estrutural
}

O grupo de organizações trabalhou com a ideia de uma ação de litigância estratégica para tratar dos casos de violações de direitos humanos no âmbito da unidade prisional. Conforme afirma Eduardo Baker, houve o desenho de uma ação de litigância estratégica, em que o Presídio Professor Aníbal Bruno reunia as características para ser uma boa escolha de caso.

Sim, por isso que o fato do Aníbal ter um pouco de tudo torna-o uma boa escolha de caso, porque dá pra tratar de quase qualquer tema que você poderia querer tratar em relação ao sistema prisional. É o que te dá

235 Por conta das violações, do número de mortes, de tudo o que estava acontecendo. Tinha-se a ideia de que se trabalhasse o Aníbal Bruno era uma representação da realidade prisional do Estado. 
espaço pra ver tudo isso. (grifo meu)

\title{
3.1.3. O monitoramento do sistema prisional pela sociedade civil pernambucana
}

\author{
"A partir daí, a gente passou a ter esse olhar de que \\ monitorando, a gente poderia intervir na realidade." Wilma \\ Melo, SEMPRI
}

Wilma Melo explica como foi sendo formado, ao longo do tempo, o monitoramento realizado pelo SEMPRI. Primeiro, houve uma formação de agentes de cidadania e direitos humanos na prisão, como uma forma de criar uma rede de pessoas que atuem como monitores do sistema prisional em várias partes do Estado de Pernambuco, e com acesso privilegiado aos presos, por serem seus familiares. A ideia, como coloca Wilma Melo, é que os familiares conhecessem como a prisão funciona, o que não ocorre normalmente.

\begin{abstract}
Além de atender familiares de preso, existe a ideia de criar um projeto para formação de agentes de direitos humanos, agentes de cidadania e direitos humanos na prisão para formar familiares de preso pra conhecer por dentro como a prisão funciona. É incrível que muitas vezes esse familiar tem um relacionamento pontual com o preso e por isso não conhece a prisão como um todo. O familiar apenas vai até onde o preso está. A gente viu isso depois de implantar o projeto. As pessoas não tinham conhecimento amplo dos espaços prisionais. Se o fulano tá no pavilhão $\mathrm{x}$, ela vai até o pavilhão $\mathrm{x}$, no máximo dá uma voltinha ali próximo. Até porque a prisão exige isso, a dinâmica prisional exige isso. Geralmente, não se fica muito exposto na prisão. Fica-se num contexto mais reservado. Até porque existe uma forma diferente na prisão de circulação. Nem marido, nem pai, nem filho vai querer a familiar circulando ali livremente. É um espaço mais reservado para essa família. É o espaço que eles têm de convivência familiar. E nesse pequeno tempo não vão querer expandir mais isso. Daí, fica cada vez mais segregado esse espaço. Foi através do MLAL [Movimento Leigo América Latina] que conseguimos financiamento para formação de 90 familiares. O curso foi em 2002 salvo engano. Esse curso trouxe essa nova perspectiva de monitoramento. (grifo meu)
\end{abstract}

Essa formação foi um intenso processo de aprendizagem que resultou em conhecimento e empoderamento de mais de uma centena de familiares, que se tornaram, além de monitoras do sistema prisional, multiplicadoras de conhecimento.

Aí passamos a fazer uma grade curricular. Não gosto nem de falar grade, nessa planilha curricular, nós colocamos matérias referentes à formação 
do agente de direitos humanos na prisão. Execução penal, quem deu na época foi Adeíldo Nunes, que foi um juiz que foi diferente. Como eu dizia, ele desceu do Olimpo e foi pra dentro de uma sala com familiares de preso, daqueles que ele cuidava da execução e era responsabilidade dele. Tinha familiares de preso de várias unidades prisionais que fizeram o curso. Ronidalva foi responsável pela cadeira de ética. Tínhamos promotores que deram aula também. Foi uma formação diferenciada. Talvez que uma universidade não teria dado pra um aluno. Inclusive a própria secretária da SERES na época, Olga Câmara, também foi professora. Foi algo histórico. Ali, o laboratório da aprendizagem foi comigo na época. O que era o laboratório? Após conseguirem o conhecimento teórico, eu preparava pra entrar na prisão como agente de direitos humanos, para conhecer a prisão como aluna e não como familiar de preso. Preparávamos isso com muito carinho, elas iam para ter um olhar sobre a prisão. É nesse momento de retorno para o trabalho final delas que eu escutei muito isso, que não conheciam a prisão, não sabiam como era a prisão. Também o empoderamento de ser tratada com dignidade, de entrar dentro da prisão com dignidade, com respeito à aluna. Foram momentos de muita felicidade. Para quem ensina e para quem aprende. Era uma troca. Uma experiência única. Projeto piloto que deu certo. Porque elas levaram isso pra vida, para suas comunidades, para seu dia a dia. Conhecer como funcionava a dinâmica de uma execução penal, de uma lei. Dizer pro marido quanto tempo ele tinha ainda pra cumprir, tomar consciência de quanto tempo ela teria ainda de entrar dentro da prisão. É muito interessante. Além disso, compreender a dinâmica prisional, os seus limites, na perspectiva do Estado de Direito. $\mathbf{E}$ aprender também o que era violação de direito. Esse era também muito importante que ela aprendesse, saber exatamente como reivindicar seus direitos. Elas passaram a ser multiplicadoras. Aprenderam a fazer uma petição simples, aprenderam a reivindicar direitos. Eu via o empoderamento delas, por exemplo, quando diziam, na porta da prisão, que eram do SEMPRI. Foram anos bons para o sistema prisional. O sistema se sentia monitorado. Havia ajuda de bolsa, transporte, lanche. Se tinha aula à tarde, tinha almoço também. Elas faziam outros cursos também. Logo depois, a Brazil Foundation contribui com mais uma turma, com 30 vagas. Então, foram ao todo 120 agentes formadas. Elas tiveram essa oportunidade. Daí gente se especializa e traça um projeto de monitoramento multiplicado." (grifo meu)

Continuo a entrevista perguntando se as agentes de cidadania e direitos humanos na prisão eram somente mulheres. Wilma Melo respondeu que formaram 4 homens e 116 mulheres. E prosseguiu: "Quando os primeiros presos foram para Catanduvas, o presídio federal,
dentre eles, foram alguns que as esposas fizeram o curso. Você conhece a
região nordeste. Nós aqui temos clima e alimentação diferente. Chegaram
lá e sofreram muito com o frio, com a alimentação. E elas procuraram o
Sempri para dizer. E nós mudamos alguma coisa. Fomos ao Ministério
Público. Quando eu fui à Brasília, fui diretamente falar sobre isso. E até em
Catanduvas a agente monitorava como era a situação, que tipo de
humilhação que as pessoas passam. Me lembro de uma que disse que tinha 
que tirar a prótese dentária porque tinha um tipo de metal que ela tinha que tirar. É uma coisa constrangedora. Então a gente passou também a monitorar também, aqui de Pernambuco, Catanduvas. Até hoje existe esse link. O pessoal procura o Sempri por conta dessa formação. A gente pensa em fazer novamente uma formação dessa porque já foram anos e já existe uma nova perspectiva, um novo olhar sobre isso. Mas foi muito interessante. O Sempri permaneceu fazendo o monitoramento e atendendo os familiares." (grifo meu) Interessante pensar como o monitoramento do sistema prisional pode ser expandido de diversas formas, justamente porque é um sistema e possui grande rotatividade de seus presos.

Sobre a experiência da formação das agentes de cidadania e direitos humanos na prisão, Wilma Melo resume que foram bons anos para o sistema prisional pernambucano, época em que havia a percepção de monitoramento. Essa também foi uma passagem importante para sua história pessoal: de familiar de preso, tornara-se professora de cidadania e direitos humanos, mais especificamente capacitando as agentes para o monitoramento na prática.

\subsubsection{Defensoras de direitos humanos e a militância profissional em direitos humanos}

\section{"Não estou dentro do perfil do corpo dócil." Wilma Melo, SEMPRI}

Apesar de ser um tópico de interesse indireto para essa pesquisa, faz-se necessário aqui já que haverá uma conexão posterior quando se adentrar no tema da proteção especial que a Corte IDH concedeu à Wilma Melo, em função de estar ameaçada em relação à sua vida e integridade pessoal. Ainda, julguei importante trazê-lo, não para debater exaustivamente o tema, mas, sim, para contribuir com outros debates que estão em curso. Para ela, a capacidade do SEMPRI de incidir na realidade está umbilicalmente ligada à independência financeira da organização. Portanto, coloca-se como defensora do trabalho voluntário em direitos humanos, contrapondo-se, ainda que indiretamente, à profissionalização dos militantes de direitos humanos, referindo que esses têm de ser mais comportados.

A gente quer realmente fazer um trabalho voluntário. Daqui a alguns anos eu vou escrever sobre o trabalho voluntário. Ser voluntario não é fácil. Eu trabalho, eu dou aula. (...) É muito complicado porque você precisa ter linhas de atuação [referindo-se ao militante profissional de direitos 
humanos]. Sua linha de atuação não tem muito a perspectiva ativista, de militância. Tem de ser mais comportado. Como eu sou mal-comportada... (grifo meu)

Ressalta-se, novamente, a decisão de não adentrar no tema. Contudo, parece-me interessante, pensando em uma rede de organizações da sociedade civil, que os tipos de militância possam se misturar - os voluntários, os profissionais e os acadêmicos -, até para que os vários perfis possam contribuir de maneira construtiva para a ação coletiva a ser criada e levada a cabo.

\title{
3.1.5. A formação da rede
}

Wilma Melo conta que, do ponto de vista do SEMPRI, tudo ocorreu por conta do trabalho em conjunto já realizado havia muitos anos com a Pastoral Carcerária.

\begin{abstract}
Aí acho que essa questão de monitoramento e desse entrosamento que a gente sempre teve com a Pastoral Carcerária. Muitas pessoas até me confundem com Pastoral Carcerária. Mas sendo ecumênico é a nossa proposta. Somar e nunca dividir. Aí em 2010, Fernando teve no Brasil e chegaram num consenso com a Justiça Global e com a Pastoral Carcerária, nessa época José, acho que você conheceu José, que a situação de Pernambuco era dramática e resolveram vir a Pernambuco para ver a situação carcerária de Pernambuco. (...) Padre Vilmar também na angústia dele de tanto querer junto com José, a estadual e a nacional [Pastoral Carcerária] se uniram a Sandra [Justiça Global] e a Fernando, que é da Clínica de Direitos Humanos de Harvard resolveram vir a Pernambuco e olhar essa situação tão dramática do sistema prisional.
\end{abstract}

Em outra passagem, Wilma Melo lembra como foi construído o primeiro relatório da rede de organizações, que foi posteriormente enviado à Comissão Interamericana de Direitos Humanos.

Em 2011, após essa visita (2010), foi construído um relatório. E Fernando perguntou se poderia passar o relatório para mim para que eu conhecesse o que iria ser apresentado à Comissão. Disse que eu ficasse à vontade pra ajudar. Fiz alguns ajustes que eu achava necessário sobre a questão do chaveiro. Desenhava mais pontualmente a questão do chaveiro e outras questões. E aí ele chegou e perguntou se o SEMPRI não subscreveria. Daí que o SEMPRI começou. Foi nesse momento que o SEMPRI começou, quando foi solicitado à Comissão Interamericana de Direitos Humanos. O primeiro relatório já estava subscrito pelo SEMPRI, mas foi assim, uma conversação inicial. (grifo meu) 
$\mathrm{Na}$ perspectiva da Justiça Global, a Pastoral Carcerária também foi a organização que fez o contato inicial, sendo que as organizações possuem, desde longa data, trabalho em conjunto no âmbito do sistema prisional. Eduardo Baker conta que

O contato inicial foi com a Pastoral na verdade. Foi através da Pastoral que a gente entrou em contato com a Wilma. E com a Pastoral a gente já tem contato de longa data. A gente já trabalhou com ela em alguns casos e por um bom tempo, né? Às vezes, diretamente com a Pastoral, às vezes com as entidades parceiras. No caso de Porto Velho, com a Arquidiocese, então, assim, vai mudando. E com a Pastoral a gente foi apresentado à Wilma e aí que começou, formou a rede. No caso, com a Clínica de Harvard a gente também já trabalha com o Fernando há muito tempo, né? Ele trabalhou na Justiça Global por um certo tempo e há um bom tempo atrás. Depois, ele continuou, depois ele foi pra Harvard, começou na Clínica que era o James [Cavalaro] que coordenava, nós temos uma relação com o James [Cavalaro] há muito tempo. É como costuma funcionar atualmente a Justiça Global. São parceiros, na parte de prisão, de longa data. E tinha essa situação do Aníbal Bruno que era mais ruim ainda do que já é. E tivemos a ideia de apresentar as cautelares, né? (grifo meu)

\subsubsection{Formação da rede já com a ideia de internacionalizar a demanda}

Questionado sobre se já existia a ideia de ingressar com a medida internacional, Eduardo Baker responde que

\footnotetext{
Sim. A Justiça Global trabalha principalmente nessa parte de litigância internacional quase que exclusivamente com o Sistema Interamericano. Claro que também tem algo de Sistema ONU, mas é pouco, é mais Sistema Interamericano. Em relação ao sistema prisional, tem um histórico longo, de Sistema Interamericano, além do Urso, que já teve medidas cautelares no passado. A ideia foi um pouco essa, pra ver o que acontecia. (grifo meu)
}

\subsubsection{O significado da coalizão?}

Wilma Melo afirma que a rede de organizações da sociedade civil, nos idos de 2010, trabalharam em parceria. Contudo, com o tempo, o trabalho e a convivência, o conjunto passou a ter mais importância que as partes.

A partir dali se fundamentou essa inicialmente parceria, que eu chamava 
também de consórcio. Para atingir essa formatação neoliberal. A coisa vai caminhando. E aí Fernando diz que era uma coalizão. E a gente comprou a ideia imediatamente, que é uma coisa muito mais do conjunto do que de partes. (...) E daí a gente caminha. Cada vez que a gente caminha junto, mais a gente aprende.

E continua, explicando como surgiu a ideia de coalizão para designar a rede de organizações.

No início a gente tinha a ideia de parceria, logo no início era parceria. Depois foi tendo uma afinidade tão grande que ninguém mais trabalhou como partes, a gente foi percebendo que a gente não era mais partes, mas um todo. Acho que Fernando sai com essa pérola de coalizão exatamente por essa percepção, que a gente passou a trabalhar realmente como um todo, ninguém é mais do que ninguém, a gente consegue compreender exatamente qual é o papel de cada um, a gente consegue respeitar o que cada um tem pra oferecer. É mais bonito pensar assim. Porque cada um tem algo pra oferecer. Dentro dessa coalizão, que é uma coalizão acadêmica, cada troca é uma aprendizagem coletiva. É muito interessante. Essa troca de experiência que cada um tem torna-se uma aprendizagem coletiva. Ficou muito claro com esses últimos anos. Cada vez mais foi se fortalecendo. $\mathbf{E}$ daí ficou muito claro que é uma coalizão.

A horizontalidade, alteridade e solidariedade são indiretamente evocadas para descrever a coalizão. Além disso, um elemento que fica muito marcado em sua fala é o da aprendizagem coletiva, que ela repete algumas vezes durante a entrevista, ao se referir brevemente à experiência de ser coalizão.

\subsubsection{Divisão de trabalho dentro da rede}

Quando perguntados sobre a divisão de trabalho, Eduardo Baker disse que

Acho que acaba que todo mundo faz tudo assim né? A gente faz as visitas, a Wilma também, o relatório todo mundo escreve, acho que, nesse sentido, todo mundo faz meio que tudo. Pelo menos, em relação à produção de material, coleta, redação.

E Natália Damazio completou afirmando o que se segue: “Óbvio que o ator local faz mais visitas que os outros, até por questão de estar lá, mas, de forma geral, todo mundo participa de todos os pontos".

Eduardo Baker continua, afirmando que a Justiça Global procura fazer o trabalho 
sem esse tipo de divisão, sem divisão entre aqueles que coletam as denúncias na cadeia e os especialistas em direito internacional que processam a demanda no Sistema Internacional de Proteção dos Direitos Humanos:

\begin{abstract}
De maneira geral, a impressão que eu tenho é que a Justiça Global tenta fazer uma coisa mais assim, né, menos com divisão de tarefas. A divisão de tarefas dá espaço pra umas dinâmicas não muito interessantes. Ah, nós somos a organização especialista em direitos humanos e vocês entram na cadeia e coletam material, mandam pra gente que a gente processa. Essa é a função dos especialistas. Acho um pouco complicado essa coisa muito segmentada. (grifo meu)
\end{abstract}

De forma mais detalhada, explica que existem, sim, diferenças, mas que essas não são centrais para o trabalho:

Tem alguma diferença. Tem que fazer um argumento sobre a ampliação das medidas, baseado em direito internacional. A Wilma não vai fazer isso. Nós vamos fazer. Mas isso é uma diferença em apenas alguns pontos concretos. Depois que a medida é concedida, pouco é argumento jurídico estrito senso, então acaba que ocupa um papel menor do que no primeiro momento [antes de ser concedida] ou no litígio de um caso propriamente dito, que acaba tendo uma demanda maior de um advogado. Nas provisórias, é um pouco diferente esse formato. Mas de maneira geral a gente tenta fazer as coisas de uma maneira mais horizontal. A tentativa é mais essa. O Brasil não tem tanta gente que trabalha com essa parte, é positiva essa maneira de trabalhar.

Eduardo Baker observa algo relevante para a prática no SIDH: a depender de que instrumentos se está utilizando - no sistema de petições e casos, por exemplo, pode-se utilizar o caminho de uma petição ou o caminho de uma medida cautelar - necessitar-se-á de mais ou menos argumentação jurídica. No caso de medidas cautelares, após a concessão das medidas, como aponta, não há maiores debates jurídicos relevantes. O foco torna-se o controle da política pública, no caso, as condições em que se encontram as pessoas privadas de liberdade na unidade específica. Nota-se que não se prescinde do direito, já que existem discussões sobre execução penal e sobre responsabilização de agentes penal, civil e administrativamente, como exemplos, mas, sim, de argumentos de direito internacional. Passada a barreira da concessão das medidas, os debates são, basicamente, sobre o Poder Executivo - e a administração do sistema prisional - e o Sistema de Justiça doméstico, como funciona ou deixa de funcionar. 


\subsection{Internacionalização da demanda e obstáculos para a concretização das medidas}

\subsubsection{Por que internacionalizar a demanda?}

\section{“(...) não tem mais espaço para diálogo quando a gente está dialogando com o violador." Wilma Melo}

Fiz um questionamento sobre o Sistema de Justiça doméstico. Procurei saber o porquê das organizações não acharem válido levar o caso para os órgãos do Sistema de Justiça nacional. Wilma Melo foi enfática ao responder o que se segue:

\footnotetext{
Como se entra dentro de uma prisão e não se tem um mínimo de indignação? Se sai sem se cumprir no mínimo o seu dever? Parte daquela prisão era para estar interditada. Então justifica acionar os mecanismos internacionais? Justifica, porque não tem mais espaço para diálogo quando a gente está dialogando com o violador. Por que a gente vai dialogar com um secretário que autoriza o uso de arma letal? Dialogar com ele mais o quê? Dialogar com o gestor prisional que permite violações? Que permite que o chaveiro bata, espanque? Esse chaveiro depois não vai pro castigo, não sofre nenhuma medida disciplinar?
}

O sentido, portanto, aqui encontrado para a internacionalização da demanda é que as organizações da sociedade civil não vislumbram condições de dialogar com aqueles que violam de forma tão explícita e extensiva os direitos humanos. Nota-se que Wilma Melo não falou em eficácia ou efetividade, mas, sim, em não haver espaço para o diálogo com o violador de direitos humanos. Olhando de outra forma, pode-se dizer que, enquanto houver violações de direitos humanos, o SIDH será necessário, mesmo que o Sistema de Justiça doméstico funcione de forma adequada. Afinal, o Sistema de Justiça também é Estado brasileiro; fica também subsumido na figura do violador de direitos humanos.

\subsubsection{A tensão entre a inércia do Estado e a persistência da demanda no SIDH}

Em dado momento, Wilma Melo afirma que parece que não haver medida provisória para o Estado, no sentido de que ele não cumpre com o que lhe é ordenado. De 
posse dessa afirmação, indaguei-lhe qual o sentido para a sociedade civil de se ter um caso no Sistema Interamericano de Direitos Humanos, apesar de sua aparente ineficácia.

É acreditar, Julia, que ainda existe caminhos e que a gente não vai desistir enquanto existir caminho. O mínimo que acontece é a certeza de que há possibilidade, quando a abolição da revista vexatória, é concreto o resultado, quando nós conseguimos no monitoramento que a cela número 5 no pavilhão ' $n$ ' fosse desativada é a certeza de que ainda há possibilidade de mudança. Talvez essa coalizão venha quebrar alguns paradigmas. Na forma de trabalho, na forma de fazer, na forma de acreditar que é possível. (...) É um grande ganho de aprendizagem, de transformar parceiros numa rede de coalizão. Por mais que o estado não faça, a gente sabe e é concreto que ele está em litígio internacional. Esse constrangimento ele não tem como negar. Por esse constrangimento ele fica sempre devendo uma resposta pra sociedade. (grifo meu)

Sobre essa questão do impacto, Eduardo Baker responde que

Você tem resultados, né? Poucos e tímidos, mas você vê algum impacto. É bizarro imaginar a necessidade de esforço que você tem pra coisas tão pontuais às vezes, né? Tipo ter coleta de lixo na cadeia, mas acaba sendo que a gente sabe que só pedindo é difícil, né? No âmbito interno é complicado esse tipo de funcionamento. A gente já fez pedido para intervenção de presídios e coisas do gênero. Tirando algumas coisas pontuais em lugares específicos, dificilmente você consegue alguma coisa mais substancial no judiciário, né? Agora, com essa ADPF aí do PSOL e do Sarmento vamos ver se a coisa muda um pouco, mas até o momento a coisa é mais complicada. Talvez a coisa mude um pouco de figura. Mesmo tímidos, os resultados existem no Sistema Interamericano. A gente acaba tendo muita dificuldade na parte de responsabilização das pessoas envolvidas, não só na responsabilização criminal. Pessoas morrem, pessoas ficam sem assistência judiciária, pessoas ficam sem assistência à saúde, e o máximo que se tem às vezes é a indenização da pessoa ou da família. A gente até hoje não conseguiu descobrir um mecanismo eficaz de responsabilização, para implicar as pessoas envolvidas concretamente. É um problema que a gente tem, não só em relação à prisão, mas nesse caso específico também tem essa dificuldade.

Portanto, levar a diante a demanda, por mais que não sobrevenham os impactos desejados, tem relação com um constrangimento constante em que resta colocado o Estado brasileiro, de que se encontra em litígio internacional por tal e qual violação de direitos humanos. Compreendo o que Wilma Melo quer dizer. Em minha experiência na Assessoria Internacional da SDH/PR, o constrangimento manifestava-se todos os dias. É difícil descrever, pois são vários pequenos gestos, atos e ações e, infelizmente, somente em poucas 
ocasiões os eventos são condizentes com o constrangimento que realmente existe, na sua proporção real. Contudo, quantas vezes, em função de uma comunicação da Comissão Interamericana de Direitos Humanos, dezenas de pessoas se reúnem, debatem problemas e soluções, chegam a acordos e colocam em ação planos a fim de concretizar as determinações do SIDH? As tentativas que não resultam em acertos restam invisibilizadas; em razão disso, tem-se a sensação de que nada funcionará para solucionar as mazelas do sistema prisional brasileiro. Contudo, segundo Wilma Melo, resta o contínuo constrangimento do Estado brasileiro.

\subsubsection{A resposta do Estado brasileiro}

\section{“Não vejo outro caminho.” Wilma Melo}

Ao tratar do que atualmente ocorre no Presídio, Wilma Melo relata que

Entre 2011 e 2014 nada foi feito. Nem o lixo foi resolvido. De 2011 a 2013, o que foi que aconteceu? Qual foi investimento que se teve? O que houve entre 2011 a 2012? Mais uma rebelião de grandes proporções. A Comissão entendeu ampliar e não reduzir as medidas, o que não é comum, você sabe disso. O caso do Aníbal Bruno é emblemático porque houve aumento e não redução de medida cautelar. Por quê? Porque o estado não tomou atitude, ele menosprezou as relações internacionais, seus compromissos internacionais com direitos humanos. E pouco fez. Quando aumentou, o que foi que aconteceu? Fizeram uma atividade melhor. 2013. Fizeram concurso, mas não chamaram. Pela falta de atenção do estado, em 2014, as medidas transformam-se em provisórias. Em 2013, houve uma melhora na questão da saúde, não melhora, mas pelo menos tenta-se fazer algumas cirurgias, se organizar a questão da saúde, mesmo assim de forma muito deficitária, tão deficitária que a Comissão resolveu peticionar à Corte pra o agravamento das medidas. Desde maio de 2014, houve um impacto. Em 2013, já havia chamada de agentes penitenciários. Em 2014, houve um impacto de imediato, conseguimos sensibilizar para a questão da revista vexatória, a abolição da revista vexatória. Esse foi um grande impacto. Para o Brasil também, não só pra Pernambuco, com resolução do CNPCP, tudo a partir de maio de 2014. O juiz das execuções penais faz isso em caráter de portaria, e logo depois o Secretário Bernardo cria para todo o sistema penitenciário e subscrito, assina $o$ governo do estado e o conselho estadual de defesa dos direitos humanos. Foi um momento marcante. Ali ficou reconhecido os papeis de cada um. Foi o único momento que a gente pode dizer que houve o reconhecimento que a medida seria responsabilidade de todos. (grifo meu) 
Falando sobre a questão do lixo na unidade prisional, Wilma Melo chega à conclusão de que não vê outro caminho que não seja o Sistema Interamericano de Direitos Humanos:

\begin{abstract}
Houve um posicionamento, houve também em 2014 a proposta da criação de colocar em prática o programa da política de saúde para presos. 2014 foi um ano de grandes avanços. Inclusive a partir da medida provisória houve o planejamento e o estado se compromete a resolver o problema do lixo. Uma das coisas, Julia, que mais me impacta é saber que a gente tem que acionar mecanismos internacionais para tratar de uma questão básica, o lixo. Eu disse isso agora recentemente na Corte, na audiência. Isso até envergonha, entendeu? Você dizer que seu estado precisa de uma medida provisória, porque uma medida cautelar não foi suficiente para ele se lembrar de cuidar do lixo, que nem precisaria disso. E depois de quatro anos o estado dizer que todas três unidades têm containeres para lixo. Se o estado trata o lixo do mesmo jeito que trata o preso, como lixo. $O$ mesmo jeito que ele trata os profissionais como lixo. Então tudo no sistema é tratado como lixo. E o próprio estado acredita que vai punir também tratando como lixo. Nem o lixo ele trata dentro desse local porque tudo é lixo. Tudo é lixo. Não vejo outro caminho. (grifo meu)
\end{abstract}

Ainda sobre a questão do lixo, pergunto sobre a partir de que momento foi resolvido o problema do lixo. Wilma Melo responde que

(...) a partir do momento que se cria, que a Corte pede na medida provisória o planejamento, que eles encaminham o planejamento. Mas mesmo assim só vem terminar o último container agora. E mesmo assim a situação do lixo não está definitivamente resolvida. Ter container não quer dizer ter educação ambiental. Porque ainda nós presenciamos amontoados de lixo, mesmo com container. A prefeitura também não faz a coleta corretamente. Tem que ter uma coleta, tem que entrar dentro da prisão. É uma questão da saúde, da insalubridade, a superlotação, a superpopulação. $\mathrm{O}$ estado não quer. Houve um incêndio recentemente. A unidade não tinha sequer um extintor. $O$ estado não tem um programa contra incêndio. Resultado: morreram duas pessoas. Os presos morreram queimados. $\mathrm{E}$ as gambiarras continuam as mesmas. Ou seja, o estado não está fazendo muito.

Quando perguntada sobre como estava funcionando o Comitê Estadual de Prevenção e Combate à Tortura, Wilma Melo respondeu que

Eu assumi, enquanto SEMPRI, a primeira presidência do Comitê em 2012. Deixamos como legado da nossa gestão a lei que criava o comitê, que não era por portaria, mas agora por uma lei, e a lei que criou o mecanismo. 
Foram instalados a partir da pressão da Comissão Interamericana de Direitos Humanos. (grifo meu)

Ao perguntar se o Mecanismo Estadual de Prevenção e Combate à Tortura está funcionando, Wilma Melo respondeu que sim, sendo "o primeiro mecanismo do mundo a ter uma travesti como perita". Afirmou, ainda, que, ao fazer um monitoramento em uma prisão, a referida perita foi agredida por um agente penitenciário; ele teria a ameaçado com uma arma, o que apenas aponta os inúmeros desafios que se impõem quando se coloca em prática a transversalidade dos direitos humanos. Sobre o mecanismo em si, afirma que a experiência é muito nova, que está tudo no começo.

É novo ainda, precisa entender qual é o seu papel, que não é de funcionário público, mas ainda tem essa noção, o mecanismo ainda não percebe que ele é o ator do comitê, ele pensa numa independência sem link com a política pública, que é muito complicado. (...) O mecanismo é independente, mas ele nem devia estar atrelado a um setor do estado, do governo. Deveria ser órgão do Comitê Estadual da Tortura. E o Comitê deveria ter, veja só, um fundo para pagar o mecanismo. Seria a forma melhor de se trabalhar uma política pública de combate à tortura. Porque quando esse comitê, esse mecanismo fica sob responsabilidade do estado, a situação não é das melhores. Mas é tudo começo. (...) O Comitê fez a escolha dos peritos por meio de seleção, que foi ótimo. $\mathrm{O}$ atual secretário não estava ainda. Foi outra pessoa. O secretário atual por ele, ele indicava. O processo foi muito bom. O SEMPRI sempre esteve no Comitê Estadual e no Conselho Estadual de Direitos Humanos. (grifo meu)

\subsubsection{A questão dos "chaveiros"}

\section{"O chaveiro apresenta toda a deformidade do sistema." Wilma Melo}

Quando falamos sobre a situação atual do Presídio, Wilma Melo falou, entre outros pontos, sobre os "chaveiros". Afirmou que a existência da figura desestabiliza todo o processo de monitoramento da prisão, noticiando a preocupante informação de que atualmente o "sistema de chaveiros" está mais fortalecido.

(...) você tem chaveiro dentro do sistema que ele está atrelado a um sistema formal que dá condições para que ele exerça uma função paralela ao estado, mas com o consentimento do estado, que é uma função de segurança. $E$ isso desestabiliza todo um processo inclusive de monitoramento porque o preso chaveiro tem o domínio sobre várias situações inclusive da vida. Antes mesmo da coalizão já enfrentávamos 
situações muitos difíceis, inclusive de chaveiros fazerem a lista de quem ia para Catanduvas, de quem ia pro RDD. Não é hoje diferente. O chaveiro hoje diz 'se tiver fulano e fulano a cadeia vai ficar mais calma porque eles são problema no pavilhão'. Hoje a coisa é tão fortalecida que temos chaveiro como se fosse uma função de estado. $O$ chaveiro treina outro chaveiro que vai ficar no seu lugar, ele vende a função pra outro. E por conta disso se monta uma guerra de pessoas, um querendo derrubar o outro. É uma posição de privilegio, então um denuncia o outro pra assumir o cargo do outro. É tão interessante porque é como se fosse um espaço político-partidário. É muito interessante, ele tem que convencer os outros que ele tem que derrubar o chaveiro pro outro assumir. E o outro que vai assumir, que vai fazer toda essa relação, é muito esquisito porque nessa relação ele tem que ter também anuência do diretor. Não basta conquistar, tem que ser o que o diretor quer. É um sistema autoritário, onde a tortura existe, onde existe uma corrupção velada, mas silenciosa, então na época falar do chaveiro é falar de todo o sistema penitenciário. Não adianta matar um chaveiro porque a família é grande. Em qualquer cadeia a gente se comunica e quem tem de morrer vai morrer. (grifo meu)

Sobre o ano de 2015, Wilma Melo apresenta-se pessimista em relação à questão dos "chaveiros", apontando que

Houve um retrocesso porque a partir de 2015 com a mudança de gestão o que aconteceu? Voltou a questão do chaveiro, ficou muito mais preocupante, voltou ao que era antes. O chaveiro continuou agora com um poder de decisão muito grande. Durante os nossos monitoramentos, nós percebemos muito isso. Havia se quebrado em algum momento esse poder do chaveiro. Hoje o poder dele foi reforçado. (grifo meu)

\subsubsection{Monitoramento limitado}

Além da limitação imposta pela presença dos "chaveiros", a atual proibição do uso da máquina fotográfica não é novidade para as organizações que monitoram o então Presídio Professor Aníbal Bruno, atual Complexo do Curado. Entre 2012 a 2013, quando o caso estava em trâmite perante a CIDH, houve um período em que o uso de igual forma foi proibido.

A percepção que eu tenho é que nesses 10 últimos meses a situação ficou muito mais conflituosa. Aí reaparece, né? Em janeiro, a gente já teve rebelião, já voltamos a ter mortes e mortes dentro da prisão. A prisão foi fatiada em três, criaram-se três problemas porque os muros entre elas servem de comunicação pra malote pra tudo que você pode, pra arma branca, pra tudo; a prisão está cada vez mais armada. Mesmo com arma 
branca. Houve uma regressão. $\mathbf{E}$ houve também a proibição da imagem. Nós fomos proibidos. Foi em abril, maio desse ano. Simplesmente foi porque o gestor fala que é por causa do plano de emergência que foi de janeiro que a gente não poderia usar a máquina. Quando o Protocolo de Istambul, aquela recomendação do $\mathrm{CNPCP}$, que é exatamente em cima daquela visita em Recife, que era um dos membros do Conselho, que fez a pergunta, procurando saber por que a gente não entrava com máquina na audiência pública. Aí ele leva essa situação e enfim sai a resolução do Conselho. Ele não respeitou a recomendação, a resolução de ninguém. Ele não reconhece os princípios de Paris, ele é muito assim. Mas ele não respeitou a recomendação de Istambul. (grifo meu)

Importante salientar que a Resolução do $\mathrm{CNPCP}^{236}$ - citada por Wilma Melo foi justamente uma resposta à abusiva proibição de 2012-2013, proveniente da administração prisional do Estado de Pernambuco. Ou seja, a Resolução foi emitida em 2013, encontra-se em plano vigor, e o novo administrador prisional - em 2015 - resolve não mais aplicá-la, com a justificativa de que um plano de emergência está em curso. Perguntei se o Secretário, mesmo depois da audiência na Corte Interamericana de Direitos Humanos, continuava proibindo o uso da máquina fotográfica. Wilma Melo responde que

Até a semana passada não. Quando nós voltamos (da audiência da Corte no dia 28 de setembro de 2015), passamos a semana descansando. Tive problema de saúde. Mas para a semana possivelmente vou entrar na prisão. Não é novidade se ele disser que está, ele deve estar esperando a resolução do Corte. Lá ele já entendeu que ele deveria acatar. Agora é ver se ele vai acatar. Lá ficou bem claro. Talvez ele precise de alguma coisa por escrito. Nessa situação foi possível fazer algum tipo de informação falsa porque como a gente não tem como fotografar fica fácil de você reverter. Por exemplo, eles fizeram um castigo no PFDB sem luz sem nada e colocaram 60 presos lá. Não satisfeitos, como a gente não podia filmar, emparedaram, fizeram uma parede na frente, aí o ar não entra mais de jeito nenhum. Eu posso mandar pra você o emparedamento. Não entra mais ar de jeito nenhum. Aí eles informaram à Corte que nessa cela eles já haviam colocado entrada de ar. Eu até que acreditei. Quando eu fui lá não havia. Eles usaram photoshop, não era lá. Eu disse isso na Corte, na audiência, eu disse. Essa é a dificuldade, de eles manipularem os dados. Agora é pior ainda (que a outra gestão). Eles não têm limite. Eles criaram uma portaria junto à SDS e à SJDH autorizando o uso de arma letal em conflito. E o que é conflito? É um preso gritar com o outro e eles meter bala. Enquanto nós estávamos na audiência da Corte, no PFDB houve uso de arma letal que provavelmente matou uma pessoa fora do muro. Olha, o caminho que a gente pede é a federalização dessas investigações. Por que no próprio território não temos mais condições de nós estarmos lidando com os violadores dessa forma. (grifo meu)

236 Resolução n. 1 do CNPCP de 7 de fevereiro de 2013. Trata-se de resolução que permite registros audiovisuais e fotográficos na instrução de relatórios sobre estabelecimentos penais. 
Wilma Melo aponta para um caminho interessante aqui: a federalização das investigações sobre tortura, maus tratos e mortes. Segundo ela, "no próprio território não temos mais condições de nós estarmos lidando com os violadores dessa forma.” Indica o risco que correm os representantes dos beneficiários ao denunciaram esses crimes, além dos referentes à prática de corrupção e tráfico de drogas.

\subsubsection{O Pacto pela Vida e a superpopulação}

\section{“A gente não tem um política pública penitenciária. A gente tem os puxadinhos." Wilma Melo}

No Estado de Pernambuco, a centralidade da política pública na área da segurança encontra-se no programa chamado "Pacto pela Vida". Ao questionar Wilma Melo sobre o Pacto, ela afirmou o que se segue:

O Pacto pela Vida é um instrumento bom porque é um planejamento de estado, porém ele pactuou para a elaboração, mas não pactuou para o monitoramento de sua execução. Ninguém gosta de ser monitorado, nem fiscalizado. E eu terminei de dizer isso ontem. Quem não gosta de ser fiscalizado é porque tá errado. O monitoramento é positivo, ele é proativo, não é pra detonar ninguém. Quando da abolição da revista vexatória, a gente comemorou. Que bom que fez. Ou seja, é um processo avaliativo, é um instrumento de avaliação o monitoramento. E o Pacto foi inicialmente pactuado, com todos nós, nós participamos do Pacto. Porém na sua execução o acompanhamento não é pactuado. E hoje ele tem um grande valor como um programa, como um instrumento, como um projeto? Tem, mas ele não é uma política pública. É apenas um plano do governo de estado, mas a gente não pode dizer que é um plano de estado, até porque não criou um conselho, não criou política pública. É apenas um plano, não é uma política pública. Política pública a gente teria que ter todos os órgãos de controle funcionando. Primeiro a gente nem tem uma política pública penitenciária, muito menos de segurança. A gente tem órgãos que se tornam puxadinhos e cada um faz à moda da casa. Não temos uma política pública penitenciária. Porque além de execução penal, ela não pode ser considerada política pública, ela pode ser considerada o eixo para a instalação de uma política pública. O parâmetro para a instalação de uma política pública. Uma política pública penitenciária talvez fosse até descentralizar mais as questões e favorecer mais uma forma mais humana de execução ou de prisão, o que chegaria até os municípios também. As cadeias públicas seriam mais respeitadas, mais qualificadas. A gente não tem um política pública penitenciária. A gente tem os puxadinhos. (grifo meu) 
Desde que passou a ser implementado, em 2007, o Pacto pela Vida, apesar de ser um plano integrado de segurança pública, não trata da população carcerária de forma detida e refletida. Ao contrário, tem sido instrumento para o reforço da política de encarceramento em Pernambuco. Como bem esclarece Wilma Melo,

Fora isso a gente tem um Pacto pela Vida reforçando a questão do encarceramento. Além de ter a opção pelo encarceramento, ele ainda cria uma bonificação por prisão para os agentes da segurança pública. Onde a gente vai chegar? Piores salários e aí você ganha um prêmio pela quantidade de prisão que você fizer. (grifo meu)

Wilma Melo afirma que o que mudou no Aníbal Bruno no período entre o ingresso da demanda e hoje é que ali estão encarcerados atualmente 7.000 pessoas. Essa é uma informação central, autoevidente - não precisa ser debatida ou argumentada - e estarrecedora: o contingente prisional aumentou, entre 2011 e 2015, de 4.000 para 7.000 presos.

O que foi que mudou no Aníbal Bruno? Agora tem sete mil presos. No início das medidas, eram quatro mil e poucos. Hoje temos uns sete mil. O quantitativo de presos eles informavam que eram 1.148 no PJALB. De tanto a gente insistiu muito para que eles fizessem a recontagem de vagas, eles fizeram. Descobriram que não eram 1.148, mas 910 vagas. Mas o quantitativo de presos é 3.200 presos. Ou seja, pra que eles cheguem a dar uma informação precisa é muito complicado. (grifo meu)

Com a superpopulação, todas as condições na prisão - alimentação, higiene, temperatura, água potável, saneamento, lugar para dormir, banho de sol, acesso à saúde, à educação, ao trabalho, à justiça - pioram invariavelmente. Afora as questões envolvendo violência, que também tendem a ficar mais tensionadas com um contingente maior de presos, em condições ainda piores de subsistência.

\subsubsection{A questão da responsabilização}

A responsabilização dos agentes por atos ou omissões é o ponto mais difícil para cumprimento no âmbito do Sistema Interamericano de Direitos Humanos. São poucos os países que admitem, sob circunstâncias muito específicas, que seus agentes sejam punidos para além do estatuto de prescrição prevista em seus ordenamentos jurídicos, tanto no 
campo criminal, quanto no cível e administrativo.

Uma coisa que a gente tá fazendo diferente, a gente tá conseguindo que quando um preso sai de uma unidade pra outra, como é o caso do Wellington que teve a coluna deformada por tortura que até hoje ninguém foi investigar o caso do Wellington. Wellington foi o caso que na minha fala ele ficou com a fotografia chapada e eu falando. É um caso exemplar. Quem deveria estar preso, pelo que recomenda a lei nos casos de crime de tortura, é desde o secretário, pela omissão, até quem praticou. Essa fragilidade do Estado de Direito a gente tem no Brasil com muita clareza. Ninguém é responsável, ninguém se responsabiliza. Existe uma cadeia, quase uma coalizão também, só que não é uma coalizão porque aí tem interesses outros por dentro que fragiliza o estado de direito. Tem uma Lei de Execução Penal que não é respeitada. Quem é responsável por isso? O juiz? O promotor? A custódia é do executivo, mas que deve observar, fiscalizar é o Ministério Público e o Poder Judiciário. (grifo meu)

E continua sobre a falta de responsabilização dos agentes públicos:

Ele fica como depósito e fazendo tudo que desrespeita a lei porque há uma cumplicidade. Eu coloco ele aí dentro, mas tem de colocar, você cuida de qualquer jeito, mas tudo bem. A sociedade vai ter o retorno de tudo isso e vai ser o pior. A sociedade vai ter duplamente o retorno porque será afetada pela desordem comportamental que essa pessoa vai ter e porque também tá colocando uma pessoa ainda mais agressivo, deformada do que entrou. As pessoas que estão morrendo dentro do sistema prisional, por conta de câncer de fígado, falta de funcionamento dos rins, tortura, apanhou muito. Associado a droga. Essa facilitação que a gente tem, essa corrupção que a gente tem. Essa coisa absurda. Já nesse sentido eu quero te dizer que quando nós já com a medida provisória ali no puxadinho todo dia tem um preso morto. É como se não existisse a medida provisória para o estado. Eu coloco mais gente dentro do complexo, eu deixo mais puxadinho, eu permito que a corrupção mantenha a organização criminosa que me dá um retorno, que pinta a cela, que faz mais um puxadinho, que circula dinheiro, que faz a reforma física na prisão.

\subsubsection{Presídio Professor Aníbal Bruno/Complexo do Curado}

\section{"Eu acredito que a mudança do nome foi uma tentativa de descaracterizar a ação." \\ Wilma Melo}

Ao ser perguntada sobre a troca de nome do Presídio Professor Aníbal Bruno, e sua divisão em três, Wilma Melo respondeu o que se segue: 
A minha visão no início, não sei porque mudou o nome, na verdade era tentar descaracterizar a medida. Como se mudasse o nome fosse mudar a situação no mesmo espaço geográfico. A tentativa não solucionou a questão das violações. Eu acredito que a mudança do nome foi uma tentativa de descaracterizar a ação. (grifo meu)

Quando questionada sobre como as unidades funcionam hoje em dia, afirmou que

Estão (conseguindo funcionar) porque eles conseguiram institucionalizar as três unidades. Mas a situação interna é a mesma, cada vez mais agravante. É a mesma da época em que você monitorou. As câmaras frias são as mesmas, mofadas, quebrada, a comida deve mudar a qualidade por conta disso. Então, desde 2011 a gente pede uma câmara fria nova e ela continua lá do mesmo jeito. O espaço todo adulterado, todo insalubre. (...) Ele substitui hoje o Carandiru. Era uma unidade só, eles resolveram transformar em Complexo. Quando transforma em complexo, a gente tem a comparação com o complexo do Carandiru. A gente comparava com o Caradiru por ser o local que agrupava o maior número de presos. Hoje a gente compara por ser um complexo. Que antes não era um complexo, agora é. A justaposição é ainda melhor. Quanto mais pessoas, mais difícil de gerir. Não se resolveu o problema, criaram-se três problemas. (grifo meu)

\subsection{As oportunidades políticas}

\subsubsection{A preferência pelo Sistema Interamericano de Direitos Humanos}

Como já se demonstrou no capítulo anterior, a atuação internacional das organizações da sociedade civil com relação às mazelas do sistema prisional brasileiro tem sido majoritariamente centrada no Sistema Interamericano de Direitos Humanos. A partir desse dado da realidade, passei a refletir sobre o tema, sobre as razões para se preferir um sistema a outro, já que o Sistema das Nações Unidas possui alguns instrumentos que também poderiam ser utilizados. Interessei-me, portanto, em investigar a preferência das organizações pelo SIDH.

A fala de Wilma Melo é bastante esclarecedora:

Na minha visão, na visão do SEMPRI, na visão horizontal nossa, nós estamos mais próximos e é muito mais pontual você acionar a OEA pela sua especificidade; temos a Corte e a Comissão. Não digo que é 
questão de eficiência, mas acredito ser a instância mais apropriada para o caso específico contra o Brasil. A demanda para a ONU ficaria mais ampla do que pontual. Por exemplo, agora a gente tá mandando. Porque o SEMPRI também é filiado ao MNDH. Eu já fui articuladora do MNDH aqui em Pernambuco, então o SEMPRI nunca saiu do cenário da luta. Então. Várias vezes a gente teve visita de relator da $\mathrm{ONU}$ aqui e eu sempre falei do sistema prisional. Mas numa questão mais ampla do sistema, mas não na especificidade de uma prisão, de uma unidade prisional, mas no contexto sobre as violações de direitos humanos no sistema prisional brasileiro, no sistema de Pernambuco, nesse link que a gente faz, na produção de uma outra história muito mais universal do que pontual, como a gente fez agora. Mas que a ação direcionada, até porque é a OEA, ela é bem pontual. (grifo meu)

Ela aponta que existe a especificidade, a proximidade e a existência da Comissão e da Corte IDH. A palavra pontual deve ser entendida na contraposição com a palavra universal; enquanto o Sistema das Nações Unidas busca proteger os direitos humanos do mundo inteiro, o Interamericano centra seu foco nos países do continente americano, o que lhe confere as referidas especificidade e proximidade.

\subsubsection{A existência da Corte Interamericana de Direitos Humanos}

Na perspectiva de Wilma Melo, a Organização dos Estados Americanos tem uma melhor prestação jurisdicional que as Nações Unidas.

Eu acho que a OEA te dá um retorno jurisdicional melhor. É mais uma recomendação política a ONU. E a OEA é uma recomendação políticajurídica. Porque tem uma corte. E porque o Brasil é subscritor. Reconhece a corte. Nada melhor que esse caminho. Até porque mais perto, mais confortável. (grifo meu)

A existência da Corte IDH para Wilma Melo é uma diferença relevante de um sistema para outro a recomendação expedida pela ONU é meramente política, enquanto a recomendação emitida pela OEA possui caráter político-jurídico.

\subsubsection{Diferença entre o SIDH e o Sistema das Nações Unidas}

Questionado sobre a diferença entre o Sistema Interamericano de Direitos Humanos e o Sistema das Nações Unidas, Eduardo Baker pontua o que se segue: 
É bem diferente. As possibilidades, os instrumentos são bem diferentes. No caso, no Sistema ONU, você tem o Protocolo da Tortura, com o sistema de casos individual, que é mais concreto, tem o de detenções arbitrárias, mas que é muito restrito, não é amplo, e você tem a denúncia para o Conselho, mais ampla, com a utilização dos Pactos, que é uma experiência que a gente nunca teve, mas a impressão que tem um pouco é que pra uma coisa mais ampla, né? Por que a ideia desses litígios, tanto do Urso, quanto do Aníbal, quanto de vários outros, é uma tentativa mais de impacto em política pública ampla, uma tentativa muitas vezes frustrada, de usar o litígio estratégico. A partir de um caso específico, a coisa ir em outras direções. Para isso, o sistema ONU não é a melhor opção, pelo tipo de decisão que ele fornece ao final. Tem a questão do impacto midiático, que o sistema ONU é mais famoso, talvez pudesse, mas até agora o entendimento é que para algo mais sistemático o SIDH é mais interessante porque ele abre mais, como as sentenças são estruturadas, o sistema de supervisão de cumprimento, acaba tendo mais espaço para uma ingerência mais sustentada nas políticas públicas que o sistema ONU. (grifo meu)

Eduardo Baker indica uma informação importante: para uma ação sustentada no tempo, a experiência da Justiça Global indica que o litígio estratégico junto ao SIDH é a melhor alternativa. O impacto mais amplo em uma política pública tem mais chances de ocorrer com o acionamento do Sistema Interamericano, justamente por conta dessa sustentação da ação no tempo. A questão dos presídios, por exemplo, é um problema social histórico no Brasil. Não vai ser resolvido de uma hora para outra. Nesse sentido, uma ação sustentada no tempo faz mais sentido em termos de efetividade.

Sobre a resposta do Estado brasileiro ao Sistema das Nações Unidas, Eduardo Baker traz uma informação bastante desanimadora:

Um pouco da nossa experiência com o Sistema ONU é que o Brasil não responde. Mandamos pedido de informação via ação urgente e a resposta do Brasil é, no relatório, "não tem resposta". (grifo meu)

\subsubsection{O espaço mais aberto do SIDH em relação ao âmbito doméstico}

Quando questionada sobre o perfil do SIDH ser mais desburocratizado e fluido que o Sistema de Justiça doméstico, Wilma Melo respondeu o que se segue:

É muito interessante. Ontem eu queria acompanhar uma audiência no caso da Maria Clara (perita do Comitê Estadual de Prevenção e Combate à 
Tortura, que foi agredida por agente penitenciário durante inspeção), mas não pude acompanhar porque eu não tinha o curso de direito. $\mathrm{E}$ eu falei muito claro que direitos humanos está para além da visão puramente da legalidade. A visão é ainda muito limitada do que são direitos humanos. E isso eu não senti na Corte. No relato na audiência da Corte falaram todas as instituições.

$\mathrm{Na}$ comparação entre o SIDH e o Sistema de Justiça doméstico, questionei se existia algum órgão similar à Comissão. A resposta foi "não".

Não. Eu pensei até no CNJ e no CNPCP. Talvez chegasse um pouco mais perto, mas falta muito. Ainda temos uma questão de cumplicidade muito grande. O CNJ tá muito voltado para a defesa do juiz. Como o juiz, trabalhar para que ele não sofra nenhuma penalização. É forma também de dizer pro outro que ao menos é pedagógico. O sistema de justiça não está funcionando, então vamos fazer um mutirão. Isso não resolve. A prova de que não resolveu: fizeram um mutirão e o complexo está com sete mil presos. O que foi que mudou? Não mudou absolutamente nada. O CNPCP esse tem alguma coisa na sua fiscalização, chega mais próximo via resoluções. Cria resoluções, mas fica difícil de cumprir as resoluções. O CNPCP deveria estar puxando as medidas provisórias e sentando com cada estado que tem medida e tentando organizar junto com os beneficiários. $\mathrm{O}$ que acontece com as medidas provisórias? Nós, representantes dos beneficiários, somos vistos como pessoas non grata do sistema penitenciário. Não somos vistos como atores também dessa mudança. Não dão satisfação, não conversam, não chamam, o DEPEN chega aqui e entrega material. Não procuram para dizer. Há um sigilo. Não sei se é cumplicidade, mas existe o sigilo. Falta ainda que o Estado se reconheça como coalizão também. Nós já entendemos que não somos parte, somos um todo. Mas o estado não entendeu. Falta interinstitucionalidade, falta interdisciplinaridade. Falta muita coisa. (grifo meu)

Perguntei para Eduardo Baker se, dentro do Brasil, alguma instituição do

Sistema de Justiça assemelha-se à CIDH; ele responde um solene "não, do governo, com certeza, não". Logo após, indaguei a respeito do Ministério Público.

Nesse sentido, não. O Ministério Público tem uma atuação muito tímida em geral. A diferença é que a CIDH, até mais que a Corte IDH, tem uma atuação bastante desburocratizada. Você tem uma coisa mais informal, mais fluida. Essas instituições do sistema de justiça brasileiro são todas muito burocráticas, formais e engessadas, que é completamente diferente do sistema da CIDH. Você liga pra lá, fala com o advogado, manda e-mail pro comissionado, tem uma relação mais tranquila, não tem comparação com o Poder Judiciário e com o Ministério Público. A atuação é mais formal, protocolar um pedido, blablablá. A relação é mais fácil com a CIDH nesse sentido. E a outra coisa é que eles vivem disso, né? Direitos humanos. Então tem uma capacidade diferente, de um promotor 
ou juiz que vai estar trabalhando com prisão num momento e noutro vai estar denunciando alguém que desviou medicamento, então é diferente né? Eu não consigo ver nenhuma instituição do Estado que vai ter essa abertura e essa possibilidade da Comissão. Mas acho que é natural, né? O Estado tem uma função diferente do que tem a Comissão. A Comissão monitora, fiscaliza e colabora para o aprimoramento das instituições do estado. Ela tá aí pra isso aí. (grifo meu)

As indagações sobre as possibilidades de similaridade entre os órgãos da SIDH e os órgãos do Sistema de Justiça foram feitas no sentido de buscar significados para as razões que levam as organizações da sociedade civil a internacionalizarem demandas de violações de direitos humanos, quando existem órgãos nacionais com prerrogativas e com capacidade para lidar com tais demandas. Wilma Melo chegou a cogitar o CNPCP e o CNJ, mas mudou de ideia quase que imediatamente. Não reconhece no Ministério Público, apesar de suas prerrogativas e instrumentos extrajudiciais, um espaço institucional que guarde similaridades com a Comissão Interamericana, por exemplo. Wilma Melo aponta para outro lado ainda: afirma que ao Estado brasileiro falta reconhecer os representantes dos beneficiários como parte da transformação social necessária, assim como aos órgãos do Estado brasileiro falta reconhecer, uns nos outros, partes de um todo, para que se possa caminhar no sentido de resolver os problemas do sistema prisional brasileiro.

Eduardo Baker, por outro lado, é enfático ao negar qualquer similaridade de qualquer órgão estatal brasileiro com os órgãos da $\mathrm{CIDH}$, chegando a afirmar que o Estado tem função diferente da CIDH. Aponta a burocratização, o formalismo e a falta de fluidez como as características do Estado brasileiro, isso na sequência de ter respondido que a atuação do Ministério Público é muito tímida em geral. Também aponta a especialização em direitos humanos como um ponto forte da atuação da Comissão Interamericana de Direitos Humanos.

Um ponto aqui merece ser desdobrado, gerando reflexão: existem parcelas do Estado brasileiro, órgãos especializados, que trabalham com o monitoramento do sistema prisional, como se viu no capítulo segundo.

O Estado brasileiro é violador de direitos humanos em muitos casos, mas devese apontar que existem parcelas significativas dele que estão comprometidas - e não falo nas pessoas, mas sim nas estruturas institucionais - com o controle e o monitoramento do sistema prisional. O discurso pelo uso contra-hegemônico do direito - e por que não das estruturas institucionais - parece-me adequado nesse ponto, ao se enxergar não só a 
sociedade, mas também o Estado como um ente heterogêneo em constante disputa política pela sua hegemonia.

\subsubsection{Sistema de Justiça doméstico versus SIDH}

Perguntado sobre a possibilidade de explorar o Sistema de Justiça doméstico da mesma forma com o que fazem em relação ao SIDH, Eduardo Baker explica que

Tem uma questão: a Justiça Global não faz litígio interno. A primeira resposta é uma resposta institucional. Não existe essa possibilidade pra gente porque a gente não trabalha com o Poder Judiciário brasileiro. Só coisas muito específicas, coisas no STF. ADPF dos quilombolas que a gente está como amicus, mas de maneira geral a gente não atua. Essa é a primeira resposta: porque a gente não faz isso. Mas essa não é uma boa resposta. Nesse caso específico de prisão, você não tem tido uma atuação do judiciário muito proativa nesse sentido. Por exemplo, quem é o responsável por julgar essas ações? Vai ser o próprio juiz da VEP. Esse é o problema: no caso do sistema prisional, depende um pouco do regimento interno de cada Tribunal de Justiça. As atribuições para julgar as ações do sistema prisional - condições pro preso ou mesmo de violência dependem de cada TJ. Tem lugar que quase tudo vai pro juiz da VEP, por exemplo, porque ele é juiz corregedor também. Aquela coisa confusa da LEP. Nesse caso, como ele tem o dever de ofício de fazer tudo isso, ele só faz tudo isso se provocado, isso significa que ele não tá fazendo o trabalho dele de juiz corregedor. Então, é difícil esse arranjo funcionar de maneira geral. Não sei como é no RS, mas acaba caindo muito no próprio juiz do VEP ou vai cair na Fazenda Pública, mas como tem essa função de se falar que o juiz da VEP não tá trabalhando direito, então tem todo um arranjo complicado dessa coisa funcionar. Você acaba tendo interdição em alguns casos. No RJ tem algumas cadeias que foram interditadas, no Urso Branco também interditou depois das medidas lá fora, mas é muito tímido de maneira geral essas coisas. Nunca vi uma solução muito concreta. Nessa parte de responsabilização, aí que a coisa não funciona mesmo. Já viu algum diretor de presídio ser condenado administrativa ou civilmente por más condições de detenção? Por exemplo, se tem uma cadeia em que historicamente existem denúncias de tortura, não se vê o Secretário de Cadeia daquele Estado sendo responsabilizado disciplinarmente por isso. Poderia ser responsabilizado por omissão, né? No Brasil, você não vê nem tentativa disso acontecendo. Alguns países lá fora você já teve alguns casos assim, mas que também não costumam ir pra frente. Mas então é difícil, né? Você não vê o judiciário muito sensível pra isso, pra atuar. Pra mudar as coisas. Essa é pelo menos a leitura que eu tenho dos casos que eu já vi. O judiciário não tem uma postura muito combativa. (grifo meu)

O princípio da subsidiariedade leva ao desdobramento lógico de que, se dentro 
do Estado brasileiro houvesse órgãos capazes de dar conta das demandas, não haveria necessidade de que as tornassem internacionais. Contudo, ambas as respostas - tanto de Wilma Melo, quanto de Eduardo Baker - apontam para um outro lado.

Eduardo Baker afirma que o Poder Judiciário não é proativo e não é sensível para atuar na área de direitos humanos e do sistema prisional.

Em resposta anterior, Wilma Melo afirma que não há como se dialogar com o violador de direito humanos. Essa perspectiva é importante para se pensar na natureza da Comissão e Corte IDH. No sistema prisional brasileiro, todos os agentes estatais violam os direitos humanos, por sua ação ou omissão. Logo, todos os agentes estatais são violadores de direitos humanos. Será que, nesse caso, a ponderação de Wilma Melo não é válida? No momento em que um Estado não dá conta, em todos os âmbitos, de uma demanda maciça de violações de direitos humanos, é possível que somente um terceiro internacional possa auxiliar nessa difícil relação. Fica a questão: como se dialoga com o violador de direitos humanos?

Nesse sentido, nota-se que em sua última manifestação a Corte Interamericana emitiu medida específica em relação à proteção da vida e integridade pessoal de Wilma Melo, em função de ameaças que têm recebido. Em breve contato por escrito, perguntando sobre como estava, Wilma Melo afirmou que estava bem e que as coisas só estão um pouco mais tensas do que o normal delas. E repetiu pergunta sobre como dialogar com o violador.

A resposta da Corte IDH, provocada pela rede de organizações da sociedade civil, parece indicar um caminho: foi ordenado ao Estado brasileiro a proteção de Wilma Melo por meio do Programa de Defensores de Direitos Humanos. No âmbito da Organização dos Estados Americanos ${ }^{237}$, a Resolução AG/RES. 1671 (XXIX-O/99), aprovada na primeira sessão plenária de 7 de junho de 1999, dispõe sobre "Defensores de los derechos humanos en las Américas - Apoyo a las tareas que desarrollan las personas, grupos y organizaciones de la sociedad civil para la promoción y protección de los derechos humanos en las Américas" ${ }^{238}$. No Brasil, o Programa de Proteção aos Defensores dos Direitos Humanos foi criado em 2004, com o objetivo da adoção e da articulação de

237 Ressalta-se que uma das Relatorias Temáticas ocupadas por membro comissionado da CIDH trata de defensores e defensoras de direitos humanos.

$238 \mathrm{O}$ debate sobre o tema de defensores e defensoras de direitos humanos foi tratado primeiramente pela ONU. A proteção a defensores de direitos humanos, nos termos das Nações Unidas, compreende a proteção de pessoas, grupos e entidades da sociedade que atuam na promoção dos direitos humanos, conforme Resolução 53/144 da Assembleia Geral das Nações Unidas, de 9 de Dezembro de 1998, que dispõe sobre a "Declaration on the Right and Responsibility of Individuals, Groups and Organs of Society to Promote and Protect Universally Recognized Human Rights and Fundamental Freedoms”. 
medidas para a garantia de proteção de pessoas que estejam em situação de risco ou ameaça em decorrência de sua atuação na promoção ou defesa dos direitos humanos. O programa brasileiro tem como fundamento legal o Decreto Presidencial n. 6.044, de 12 de fevereiro de 2007, e está implementado nos Estados da Bahia, Minas Gerais, Espírito Santo, Pernambuco, Rio de Janeiro, Rio Grande do Sul e Ceará. Os Estados que não contam com o programa são atendidos pela Equipe Técnica Federal do Programa Federal2 ${ }^{239}$.

\subsubsection{Revisitando o "padrão bumerangue"}

Pensando sobre a diferença entre o âmbito internacional e o doméstico, questionei Eduardo Baker se eles se sentem mais protagonistas e mais ouvidos no SIDH, se sentem que naquele espaço têm um interlocutor que seja mais sensível ao que está sendo dito. Sua resposta foi a seguinte:

Sensível... Acho que não é uma boa palavra. Eu não acho que as pessoas que estão no governo federal - vocês, por exemplo, que estava lá - sejam insensíveis ao tema, mas as instituições têm sensibilidades diferentes, digamos assim. O governo federal e o estadual têm de ser provocados pra atuar. Em tese, eles não deveriam ter de ser provocados pra fazerem as coisas. Só precisar ser provocado já é um ponto contra essas instituições, né? Mas acaba que é outra forma de colocar a pressão, né? A pressão só na conversa: vamos sentar e conversar "a cadeia tá muito ruim, melhora a cadeia" não tem funcionado historicamente muito. Não só em relação à cadeia, mas em relação a qualquer coisa. Então esses espaços são uma outra forma de colocar pressão. E a esfera federal tem algum respeito pelas instituições internacionais, acaba funcionando um pouco. É claro que como tudo é muito indireto - você bota pressão no SIDH que bota no governo federal que bota pressão no governo do estado - muita coisa se perde nesse trajeto, né? Entre pressões. Mas acaba que funciona pra mobilizar os atores locais e regionais, né? Que só falando com o estado a nossa experiência não é das melhores. (grifo meu)

O "padrão bumerangue" é um instrumento que pode ser adaptado a qualquer ação coletiva transnacional, como se viu no texto de Bassano (2014). No caso em tela,

239 Não obtive informações sobre como Wilma Melo está ou será protegida, mas é um tema importante para reflexão posterior: como esse mesmo Estado violador poderá realizar a sua proteção? Mesmo que o programa seja gerido por organizações da sociedade civil, quando se precisa de segurança pessoal, por exemplo, tem-se de pedi-la ao órgão de segurança pública do Estado. Como isso pode ser feito sem que haja riscos para a pessoa que está sendo protegida? Um fator complicador desse programa é que, diferentemente do Programa de Proteção a Vítimas e Testemunhas Ameaçadas de Morte, sua função é de manter o defensor ou a defensora em sua base de luta pelos direitos humanos. Ou seja, não há a possibilidade de mandar a pessoa para longe, escondê-la. Essa função, que tem a ver com a natureza mesmo da proteção, merece especial atenção, visto que torna-se evidente a tensão entre a defensora de direitos humanos e seu violador. 
Eduardo Baker ilustra como funciona essa cadeia de pressões: as organizações da sociedade civil demandam o SIDH, que, por sua vez, demanda o Estado brasileiro. Por conta da questão federativa, a União pressiona o Estado, fechando o ciclo proposto pelo padrão. Eduardo Baker pondera que nessa longa cadeia perde-se muito a força da pressão colocada inicialmente.

Nesse contexto, importante observar que há algo no SIDH muito positivo para as vítimas e organizações da sociedade civil: previsibilidade. Por ser um Sistema, possuir dois órgãos de controle, com um procedimento quase-judicial e judicial, constituindo, assim, um corpo normativo e jurisprudencial sobre o tema de direitos humanos. Em função disso, quem aciona e conhece o SIDH sabe, em regra, o que esperar dele. Numa relação estabelecida a partir do exemplo clássico, que deu origem ao padrão bumerangue, essa previsibilidade não existe, visto que as relações têm de ser construídas uma a cada vez, mudando os atores e os contextos a cada nova demanda. Aqui, não se advoga que esse tipo de atuação não possa ser frutífera. Apenas aponta-se uma vantagem do Sistema Interamericano de Direitos Humanos, o que explica, em parte, o contínuo aumento de sua adesão pela sociedade civil que atua juntos às questões de violações de direitos humanos no Brasil.

\subsubsection{Debate-se o todo, e não as partes}

Um dos atrativos que o Sistema Interamericano de Direitos Humanos possui para as organizações da sociedade civil é sua aproximação com as complexas violações de direitos humanos de forma simples, desburocratizada e coletiva. $\mathrm{Na}$ Comissão Interamericana de Direitos Humanos, pela experiência que tenho como Estado brasileiro, a sociedade civil chega e coloca todas as questões juntas: é um pacote de violações de direitos humanos, que têm de ser traduzidas e organizadas, em termos mínimos, na forma de "ação para solução de tal violação" (política pública) e "responsável pela ação" (órgão que possui competência legal para fazê-lo). No sistema prisional, há desde questões envolvendo tortura, superlotação, alimentação, saúde, educação, trabalho. São muitas as vítimas, as políticas públicas e os órgãos competentes. Nesse contexto, as organizações podem chegar lá com essa enorme quantidade de informações e passá-las a diante pra CIDH. A Comissão Interamericana procura distribuir essas informações, realizando questionamentos ao Estado, que, depois, poderão se tornar medidas outorgadas ou recomendações específicas. Isso tudo 
levando em conta a sua vasta experiência no continente com a matéria, especialização que auxilia sobremaneira o trabalho dos advogados e comissionados que trabalham com os casos.

A atomização do Sistema de Justiça no plano interno, sem as condições e práticas para o trabalho de ações coletivas, mas, sim, preponderantemente, individuais, dificulta que as questões sejam tratadas de forma estrutural. Então, se um preso teve um problema de saúde e está pedindo uma indenização, isso vai se constituir, junto ao Poder Judiciário, numa ação específica, cujo responsável será um juiz específico, o que, ainda, demora muito tempo para chegar a um final. Outro juiz está cuidando, por meio da execução penal, do cumprimento de pena do mesmo preso. Esse é um exemplo simples, mas que ilustra como os problemas estruturais, ao ganharem tratamento da prestação jurisdicional, ficam diluídos. O Sistema de Justiça brasileiro trabalha com essa lógica do individual.

Utilizando a ideia de cadeia de pressão, proposta pelo "padrão bumerangue", o Sistema Interamericano de Direitos Humanos devolve para o âmbito doméstico o que é estrutural, o que é coletivo, e não o que é atomizado e individual.

Ao expor um esboço dessas ideias, durante a entrevista, Eduardo Baker afirmou que "a ADPF do PSOL vem nesse sentido, mas normalmente o Poder Judiciário brasileiro não é muito bom nisso. É um debate mais amplo de política pública. Lá tem esses espaços assim." Em sua perspectiva, o Poder Judiciário não é muito bom em questões coletivas, e o debate mais amplo se dá em espaços como o da Comissão Interamericana, que não possui similar dentro do plano doméstico.

\subsubsection{Arquivo Aníbal}

O Arquivo Aníbal é uma estratégia para dar visibilidade ao caso, de apontar o percurso todo que o caso teve já, que o caso caminhou, mas também uma forma de questionar o aparente sigilo que existe em torno dos casos do Sistema Interamericano. Wilma Melo coloca sua posição:

Acho também que é um estímulo, né? Pra outras pessoas, pras outras organizações. Pra conhecer também. Essa coisa mística, sacralizada, de pouco acesso, essa coisa distante. Agora é trabalho árduo. É estudar, é aprender, é aprender com o outro, aprender com o preso, aprender com a família, é uma aprendizagem, é uma troca. Ser coalizão é uma coisa muito 
especial. É você respeitar, é você entender o outro, é você aceitar nessa representação. Eu sou muito ansiosa, eu quero muito que aconteça, eu fico muito angustiada. E há uma compreensão disso. Eu sou muito ativista mesmo. Então eu fico aqui na ponta, eu tô aqui, e eu fico aqui nessa angústia junto com a Pastoral Carcerária. A questão do monitoramento é muito com o SEMPRI. Às vezes Fernando manda perguntar esse caso aí, a gente vai olhar daí. Esses facões, Wilma, tu visse, e a gente vai olhar, essas coisas todas que acontecem todos os dias e sai na mídia eles todos têm acesso e aí a gente vai mandando um pro outro quando pode e vai afinando a fala, que é uma fala única. As falas são muito parecidas.

Eduardo Baker afirma o que se segue a respeito do Arquivo Aníbal:

A ideia do Arquivo foi do Fernando e do pessoal do Harvard nessa tentativa, do que a gente sempre tenta um pouco, que é dar visibilidade para a questão. Essa pressão pela Comissão e pela Corte consegue criar um espaço na mídia que atinge o público. É um pouco essa a tentativa que é sempre uma tentativa de cavar espaço na mídia e sensibilizar as pessoas. Acho que foi um pouco nessa direção.

Natália Damazio pontua que o caso Urso Branco também tem um arquivo, mas no formato de relatório. Diz, contudo, que ambas as experiências adotam a mesma linha estratégica de proporcionar visibilidade interna para as violações de direitos humanos.

Eduardo Baker continua a respeito do instrumento, que, do seu ponto de vista, foi uma mudança em relação ao trâmite no SIDH:

Essa coisa do arquivo foi algo que mudou. E não só em relação ao Aníbal, mas de maneira geral, de tornar a coisa mais pública do que é. De maneira geral, o sistema prisional não é uma coisa muito pública, digamos assim. Tem algumas medidas que a gente toma, né? Apagar o nome de todo mundo, apagar as caras nas fotos, então tem um trabalho pra isso acontecer. Talvez tenha sido um pouco essa a principal mudança, né? Que é uma mudança de estratégia no litígio também: a coisa mais fora. [...]

Os regulamentos não são claros em relação a isso, ao sigilo. A princípio, os documentos são sigilosos, mas isso não está escrito em lugar algum. É muito confuso. O sigilo é baseado no dever de preservação dos presos. Não se pode publicizar nada. Esquisito. Essa justificativa é que se usa historicamente.

Segundo informações retiradas do próprio Arquivo Aníbal, sua metodologia é a

seguinte:

Autoridades competentes no âmbito internacional, federal e estadual possuem cópias integrais dos autos do processo internacional sobre o 
Complexo Prisional do Curado (antigo Aníbal Bruno), incluindo anexos, o que possibilita a tomada das providências devidas com respeito às denúncias encaminhadas. A decisão de publicar os autos após anos de litígio nos órgãos interamericanos de direitos humanos da Organização dos Estados Americanos (OEA), parte da avaliação de que tais medidas não vêm sendo efetivamente implementadas pelo Estado, necessitando, portanto, a busca de caminhos complementares para a garantia dos direitos. Para fins da publicação das principais peças processuais dos autos aqui apresentadas, certas informações foram ocultadas para preservar privacidade, segurança e integridade investigatória. Não houve tempo hábil para preparar os anexos dos documentos de litígio e peças meramente processuais para publicação nos mesmos termos, dado o imenso volume desse material. Foram retiradas as informações nos documentos que possam identificar solicitantes de diversos tipos de assistência (geralmente jurídica ou médica); denunciantes, vítimas ou acusados de violações de direitos humanos ou demais irregularidades; assim como outras pessoas possivelmente vulneráveis, sejam estes presos, familiares de presos ou funcionários do Estado - pessoas que circulam dentro do Complexo. Informações ocultadas incluem nomes, números de identificação, filiação, apelidos, rostos e tatuagens. Em certas ocasiões, foi necessário ocultar alguma outra informação que poderia revelar a identidade de uma dessas pessoas. Também foram retirados contatos privados, assinaturas e dados semelhantes.

Notei que as organizações da sociedade civil fazem uso dos jornais diários para monitoramento da situação da segurança pública em Pernambuco. O envio de manifestações frequentes, tanto para a Comissão, quanto para a Corte, de acordo com as violações encontradas - inclusive, muitas vezes, por conta desse monitoramento dos jornais - é um mecanismo importante, porque não depende de informações oficiais do Estado, e faz a ponte entre a realidade vivida em Recife e os órgãos de proteção que se encontram tão distantes nas cidades de Washington e de San José.

O uso do monitoramento dos jornais, para a obtenção de informações sobre o que está ocorrendo dentro da prisão, além dos dados colhidos nas inspeções, visitas e entrevistas com autoridades e, ainda, a inserção das organizações em organismos de direitos humanos, toda essa informação aliada à experiência/envolvimento em outros casos do SIDH sobre sistema prisional, faz com que o acúmulo de prática e reflexão no tema por parte das organizações seja muito grande, profundo e de enorme relevância para a melhoria do sistema prisional. Em algumas manifestações da rede de organizações do caso Aníbal Bruno, houve a menção a alternativas buscadas no caso UNIS ou Urso Branco, o que evidencia o referido acúmulo.

Debates, da mesma forma, como superencarceramento, e a crítica à construção de presídios como saída para a questão da superpopulação carcerária no Brasil, também só 
foram possíveis por meio do acúmulo e da percepção de que o problema do Aníbal Bruno não é apenas do Aníbal Bruno, nem apenas do sistema prisional de Pernambuco, mas, sim, do sistema prisional brasileiro como um todo.

As organizações da sociedade civil utilizam o Sistema Interamericano de Direitos Humanos para realizar suas demandas de promoção e proteção de direitos humanos no Brasil. As violações mais comuns envolvem violência policial, sistema prisional, sistema socioeducativo, indígenas e tortura. Pouca é a produção acadêmica sobre o tema, mas existem alguns registros de estratégias utilizadas pela sociedade civil.

Um deles é a experiência do pedido de medidas cautelares dos Guarani-Kaiowá do Mato Grosso do Sul, capitaneada pela Justiça Global. Em resumo, Sandra Carvalho e Eduardo Baker (2014) afirmam que, mesmo sem ter havido a adoção das medidas cautelares requeridas em 2012, houve impacto em função do pedido realizado, fazendo com que houvesse uma resposta estatal:

\begin{abstract}
"Por outro lado, a tramitação do pedido criou um fluxo entre os atores envolvidos, fortalecendo a parceria, e pressionou o Estado a se movimentar, ainda que de forma muito incipiente, por exemplo, formulando e aprovando um Plano de Segurança para parte do Estado do Mato Grosso do Sul para a proteção de algumas aldeias indígenas, ainda pendente de implementação efetiva. Durante esses meses, outros atores se somaram ao processo e passaram a compor essa frente de direito internacional dos direitos humanos na proteção do povo Guarani-Kaiowá do Mato Grosso do Sul. De forma temporária ou permanente, a Advogados Sem Fronteira, a Associação de Juízes pela Democracia, a Anistia Internacional e a Fian atuaram, ou atuam, nesta direção. Esta última organização, a Fian Brasil e a Internacional, aproximou-se mais fortemente na construção dessas iniciativas, principalmente pelo fato de que já desenvolviam há anos um trabalho junto aos Guarani-Kaiowá sob outra perspectiva, a da segurança alimentar. Passamos a formular outras estratégias de incidência internacional."
\end{abstract}

Muitas vezes, portanto, apenas uma comunicação à CIDH sobre a ocorrência de violação de direitos humanos pode auxiliar em uma estratégia de enfrentamento à situação. No sentido da máxima efetividade dos direitos humanos, busca-se ainda a cooperação entre os Sistemas das Nações Unidas e os regionais (ALENCAR, 2010), no que está se chamando de proteção multinível. As estratégias da sociedade civil podem ser pensadas das mais variadas formas, utilizando-se da proteção multinível para reforçar denúncias de violação de direitos humanos e, sem cair nas armadilhas da litispendência internacional, que responde tão somente a pouquíssimos casos, já que para tal caracterização deve haver a petição a um 
órgão jurisdicional ou quase-jurisdicional, com identidade total de partes, fato e norma infringida.

Como as estratégias são muito diversas e não existem apenas possibilidades que impliquem jurisdição ou quase-jurisdição. Um exemplo recente de proteção multinível é o trabalho feito pela ONG Conectas: utilizam o espaço do Conselho de Direitos Humanos das Nações Unidas para realizar manifestação oral e escrita, denunciando a situação do sistema prisional brasileiro, apontando o Presídio de Pedrinhas, no Maranhão, como emblemático dessa violação em massa. Entretanto, a mesma organização também é peticionária do caso Pedrinhas junto ao SIDH, que se encontra no momento em sede de medidas provisórias na Corte IDH. Trata-se da mesma denúncia de violação de direitos humanos, apenas em termos alargados, o que não gera litispendência internacional. 


\section{CONSIDERAÇÕES FINAIS}

Um dos pressupostos deste trabalho, no começo da aproximação com o Sistema Interamericano de Direitos Humanos, é de que as organizações da sociedade civil acessam o sistema internacional porque o Sistema de Justiça doméstico demonstra-se, de alguma forma, ineficaz. Refleti, num primeiro momento em formas para aperfeiçoar essa relação entre sociedade civil e prestação estatal de justiça, a fim de que o SIDH não tivesse de ser acionado tão frequentemente.

Deparei, contudo, com uma realidade inteiramente diversa do pressuposto. Os resultados da pesquisa apontaram para outro caminho.

Primeiramente, deve-se observar a distância física entre sociedade civil e órgãos internacionais protetivos de direitos humanos não é algo totalmente negativo. Há notórias dificuldades para o acesso ao Sistema Interamericano de Direitos Humanos pela sociedade civil. Contudo, os dados levantados pela pesquisa indicam que a distância do Brasil para Washington - CIDH - ou para San José - Corte IDH - funciona de forma positiva para a sociedade civil.

Deve-se apontar que existe um certo entendimento entre os membros das organizações consultadas com a Comissão e Corte, seus comissionados, juízes, assessores e estagiários. A sociedade civil pensa nesses órgãos como seus parceiros, o que não acontece de forma generalizada com os órgãos do Sistema de Justiça no plano interno. O extenso repertório de relatórios, decisões e jurisprudência desses órgãos constitui-se em manancial valioso para as defensoras e defensores de direitos humanos de todo o continente.

O segundo ponto, ao referir a questão da distância entre sociedade civil e órgão protetivo, reside justamente na maior autonomia e independência desses órgãos, ao menos em relação aos temas que são levados pela sociedade civil a seu conhecimento. Por vezes, a sociedade civil ressente-se da atuação dos órgãos de prestação estatal do Sistema de Justiça justamente por conta da proximidade com que esses se encontram dos violadores de direitos humanos, quando não é o caso de os próprios o serem.

Em função dessas questões desveladas durante a pesquisa, o ponto-chave não se encontra mais focado em descobrir como os órgãos do Sistema de Justiça doméstico podem se assemelhar aos órgãos protetivos do SIDH, mas, sim, em compreender que o distanciamento físico para temas de direitos humanos - portanto, a distinção entre os planos 
local, nacional e internacional - pode ser um fator relevante para a construçao de agenda e fortalecimento das lutas dentro dos países.

Pela natureza contra-hegemônica dos direitos humanos, seus avanços somente se dão nas frestas, beiradas e vácuos do sistema hegemônico, que também é o Sistema de Justiça doméstico. Não é possível imaginar um Poder Judiciário brasileiro que seja, em sua maior parte, organizado em função dos direitos humanos. A natureza do Poder Judiciário, do Ministério Público, das Polícias e até das Defensorias Públicas apontam, em larga medida, para a preservação da hegemonia, e não o contrário.

Portanto, o esforço político da sociedade civil não deve ser no sentido de tornar o Sistema de Justiça brasileiro mais parecido com o Sistema Interamericano de Direitos Humanos; fundamental é construir as capacidades na própria sociedade civil para se avaliar, na prática, o que as violações de direitos humanos impõem e quais são as brechas para o exercício da contra-hegemonia que existem nos órgãos que trabalham para a manutenção da hegemonia, utilizando-se o sistema internacional protetivo de direitos humanos como alavanca. Para tanto, a CIDH e a Corte IDH oferecem inúmeras ferramentas.

Em relação ao cumprimento das obrigações pelo Estado brasileiro, o estudo de caso apontou que a atenção da sociedade civil encontra-se nas questões estruturais, e não em casos pontuais. Os casos pontuais são utilizados como emblema para que ilustrem os problemas estruturais. A base mesmo da litigância estratégica reside nessa ideia: a partir de um caso concreto, abre-se espaço para debate da questão mais ampla, buscando uma solução que venha a reparar a violação, assim como evitar que outras similares ocorram no futuro.

Como restou evidente em relação ao sistema prisional, essa ideia agrega-se perfeitamente à discussão. Portanto, mais do que um esforço para que os órgãos domésticos do Sistema de Justiça cumpram as recomendações, decisões e sentenças da Comissão ou da Corte IDH, deve-se focar em reflexões e ações que trabalhem com a concretização dos parâmetros interpretativos interamericanos, com base na Convenção Americana de Direitos Humanos e na rica e diversificada jurisprudência da Corte.

Quanto às organizações em si, o maior achado da dissertação foi em relação à autodenominada coalizão por parte das organizações da sociedade civil. Um dos pressupostos da pesquisa é de que havia uma divisão de trabalho entre as organizações, de acordo com seu espaço geográfico e expertise acumulada. Funcionaria, de forma grosseira, da seguinte maneira: organizações locais colheriam as informações e as organizações 
internacionais ou com atuação internacional transmitiriam essa informação, já processada de acordo com seu conhecimento específico, para os órgãos de proteção.

O que restou delineado pela pesquisa é que não existe uma divisão de trabalho previamente delimitada: todas e todos fazem tudo. Nesse processo de construção coletiva, por óbvio existem alguns papeis fixos; entretanto, existe uma narrativa e uma prática que demonstram que há uma preocupação com o tema (de que todos exerçam todas as funções, dentro do possível) e de que eles enxergam produtos diversos e positivos nessa postura de trabalho em conjunto.

A ideia da coalizão mostra que as organizações possuem muitas possibilidades de construção de ações coletivas transnacionais, residindo nessa diversidade uma poderosa arma no sentido de infiltrar a contra-hegemonia nos espaços resistentes. O que fica demonstrado, ao menos em grandes linhas, é que as organizações da sociedade civil, para além de estar incidindo, mesmo que timidamente como avaliam, diretamente na política pública relativa ao sistema prisional de Pernambuco, está incidindo no debate nacional - e porque não no continente americano - ao possuir um caso no Sistema Interamericano de Direitos Humanos.

Para além de tudo isso, a coalizão demonstra que a aproximação entre as pessoas, o respeito, todas e todos fazerem todas as tarefas, é expressão de horizontalidade, o que é um salto entre o discurso de direitos humanos e sua difícil prática.

Outro achado da pesquisa é refletir sobre o "Arquivo Aníbal”. A construção desse site desafia o atual quadro posto nos procedimentos tanto da CIDH quanto da Corte IDH, em que o sigilo - que não é claramente imposto às partes - acaba tornando-se regra, na maioria das vezes em detrimento da proteção aos direitos humanos que deveria estar sendo concedida. Aqui, a sociedade civil mostra seu vigor, criatividade e capacidade de pensar, mesmo em termos jurídicos, fora dos espaços previamente delimitados.

Quanto à mobilização transnacional do direito, algumas observações merecem ser feitas. Ressalta-se uma primeira impressão, de que se poderia, eventualmente, realizar a proposição de uma nova expressão, que fundisse a mobilização transnacional do direito com os direitos humanos, criando-se, assim, a mobilização transnacional dos direitos humanos.

Depois de um certo período de reflexão, parece um equívoco o convite a tal proposta. Isso porque a mobilização transnacional do direito é um caminho, um processo, um instrumento, que qualifica, densifica, concretiza os direitos humanos. Seria tautológico, 
portanto, levar adiante tal ideia. Restou nítida a linha divisória entre o direito e os direitos humanos; portanto, falar em mobilização dos direitos humanos não faz sentido, já que a ideia de mobilização é, justamente, ser o meio - direito - para o atingimento de um fim direitos humanos.

O que se deve observar com atenção é que a mobilização transnacional do direito tem relação, no contexto aqui proposto, intrínseca com os direitos humanos. Ou seja, reputa-se relevante o uso dessa expressão, e realizou-se sua eleição dentre tantas outras expressões possíveis - ação coletiva, advocacy, litigância estratégica, formação de rede, ativismo, entre outras - pela simples razão de que ela comunica de maneira integral a ideia que se pretendeu expressar.

A mobilização transnacional do direito abre a possibilidade de se trabalhar com o objeto que escolhi - uma demanda relativa a violações de direitos humanos dentro do sistema prisional brasileiro levada pela sociedade civil transnacional ao Sistema Interamericano de Direitos Humanos - sob parâmetros que potencializam os debates que precisam ser feitos, ao contrário de limitá-los.

Ao se empregar esse conceito e todos os seus desdobramentos - como realizado no segundo capítulo - afirma-se a importância da sociedade civil e das vítimas, da extrajudicialidade, dos saberes do cotidiano, da luta pela construção dos direitos humanos, do direito enquanto instrumento de disputa política, que pode ser manejado para um lado e para outro. A mobilização transnacional do direito de igual forma produz reflexão quanto ao caráter de historicidade do direito, das disputas sociais e políticas que existem em torno dele e mesmo de que é uma eterna construção.

Para além disso, a palavra transnacional nos permite ir para além do internacional, ou seja, passa-se da ideia de embates e apoios entre nações, mas para além do conceito de nação. É, em suma, uma expressão que mitiga, num plano internacional, o tamanho e a importância dos estados, fortalecendo a ideia de sociedade civil num plano internacional.

A divisão estanque entre os planos local, nacional e internacional, num caso perante o SIDH, apenas funciona para fins didáticos. Em realidade, o que ocorre é a sobreposições das esferas. Nesse sentido, a proposição de revisitar o "padrão bumerangue" auxilia na compreensão dessa estrutura, pois restam evidenciadas as relações que são forjadas quando do ingresso de uma demanda no SIDH pela sociedade civil contra o Estado 
brasileiro.

O que se escolheu chamar de "cadeia de pressões" funciona como uma estrutura circular, em que as organizações da sociedade civil demandan o SIDH, que, por sua vez, demanda o Estado brasileiro. O Estado brasileiro, a depender da natureza da demanda proposta, terá de ser representado por órgãos específicos, que podem variar quanto ao poder a que estão submetidos - Poder Judiciário, Poder Executivo ou Poder Legislativo (sem esquecer o Ministério Público e a Defensoria Pública que, por conta de suas autonomias, são Estado brasileiro, mas fora do alcance do Poder Executivo) - assim como quanto à questão federativa e suas competências - União, Estados e Municípios.

Nessa rede que se forma, a União - por meio dos órgãos SDH/PR, AGU e MRE - acionam outros órgãos, passando a pressioná-los para que respondam - política e formalmente - a fim de realizar manifestação perante a Comissão ou Corte IDH. Ao manifestar-se, com base nessa composição de perspectivas de vários órgãos, fecha-se o ciclo proposto pelo padrão.

A compreensão de como funciona esse mecanismo pode auxiliar na reflexão sobre as próximas ações coletivas transnacionais a serem pensadas pelas organizações da sociedade civil. A mobilização transnacional do direito possui justamente essa característica de renovação contínua e constante abertura de novas possibilidades. Isso na relação entre a sociedade civil e o Estado, mas também no âmbito das organizações da sociedade civil entre si, como se vislumbrou com a coalizão formada pelas organizações da sociedade civil no caso Aníbal Bruno. 


\section{REFERÊNCIAS}

ABERS, Rebecca; VON BÜLOW, Marisa. Movimentos sociais na teoria e na prática: como estudar o ativismo através da fronteira entre Estado e sociedade? Sociologias, Porto Alegre, ano 13, n. 28, p. 52-84, set./dez. 2011.

ABRAMOVICH, Víctor. Das violações em massa aos padrões estruturais: novos enfoques e clássicas tensões no Sistema Interamericano de Direitos Humanos. Sur - Revista Internacional de Direitos Humanos, São Paulo, v. 6, n. 11, p. 7-39, dez. 2009.

ADORNO, Sérgio. Prisões, violência e direitos humanos no Brasil. In: PINHEIRO, Paulo Sérgio; GUIMARÃES, Samuel Pinheiro (org.). Direitos humanos no século XXI. Brasília: IPRI - Instituto de Pesquisa de Relações Internacionais Fundação Alexandre de Gusmão, 2002, p. 1005-1030.

ALBUQUERQUE NETO, Flavio de Sá Cavalcanti de. Punir, recuperar, lucrar: o trabalho penal na Casa de Detenção do Recife (1862-1879). 2015. 212 f. Tese (Doutorado em história). Programa de Pós-graduação em História da UFPE, Universidade Federal de Pernambuco, Recife.

ALENCAR, Antônio M. Cisneiros de. Cooperação entre sistemas Global e Interamericano de Direitos Humanos no âmbito do mecanismo de Revisão Periódica Universal. Sur Revista Internacional de Direitos Humanos, São Paulo, v. 7, n. 13, p. 177-190, dez. 2010.

ALVES, José Augusto Lindgren. Os direitos humanos na pós-modernidade. São Paulo: Perspectiva, 2005.

ANDRADE, Vera Regina Pereira de. A mudança do paradigma repressivo em segurança pública: reflexões criminológicas críticas em torno à proposta da $1^{\mathrm{a}}$ Conferência Nacional Brasileira de Segurança Pública. Seqüência, Florianópolis, n. 67, p. 335-356, dez. 2013.

ARAÚJO, Tânia Bacelar de. Apresentação. In: BRANDÃO, Carlos Antônio. Território e desenvolvimento: as múltiplas escalas entre o local e o global. 2. ed. Campinas, SP: Editora Unicamp, 2012, p. 17-22.

ARRUDA, Raimundo Ferreira de. Por uma geografia do cárcere: territorialidades nos pavilhões do Presídio Professor Aníbal Bruno em Recife - PE. 2006. 112 f. Dissertação (Mestrado em geografia). Programa de Pós-graduação em Geografia da UFPE, Universidade Federal de Pernambuco, Recife.

AZEVEDO, Rodrigo Ghiringhelli de; CIFALI, Ana Claúdia. Política criminal e encarceramento no Brasil nos governos Lula e Dilma: elementos para um balanço de uma experiência de governo pós-neoliberal. Civitas, Porto Alegre, v. 15, n. 1, p. 105-127, jan.mar. 2015.

BASSANO, David. The boomerang pattern verification and modification. PEACE \& CHANGE, v. 39, n. 1, p. 23-48, jan. 2014. 
BAUMAN, Zygmunt. Globalização: as consequências humanas. Trad. Marcus Penchel. Rio de Janeiro: Zahar, 1999.

BERNARDES, Márcia Nina. Esferas públicas transnacionais: entre o realismo vestfaliano e o cosmopolitismo. Revista Direito GV, São Paulo, v. 10, n. 1, p. 269-294, jan./jun. 2014.

Sistema Interamericano de Direitos Humanos como esfera pública transnacional: aspectos jurídicos e políticos da implementação de decisões internacionais. Sur - Revista Internacional de Direitos Humanos, São Paulo, v. 8, n. 15, p. 135-156, dez. 2011.

BOBBIO, Norberto. Era dos direitos. Trad. Carlos Nelson Coutinho. Rio de Janeiro: Campus, 1992.

O conceito de sociedade civil em Gramsci. Trad. Carlos Nelson Coutinho. Rio de Janeiro: Edições Graal, 1982.

Teoria geral da política: a filosofia política e as lições dos clássicos. Org. Michelangelo Bovero. Trad. Daniela Beccaccia Versiani. Rio de Janeiro: Elsevier, 2000.

BOITEUX, Luciana. Brasil: reflexões críticas sobre uma política de drogas repressiva. Sur Revista Internacional de Direitos Humanos, São Paulo, v. 12, n. 21, p. 1-6, ago. 2015.

BRANDÃO, Carlos Antônio. Território e desenvolvimento: as múltiplas escalas entre o local e o global. 2. ed. Campinas, SP: Editora Unicamp, 2012.

BRANDÃO, Marco Antônio Diniz; BELLI, Benoni. O sistema interamericano de proteção dos direitos humanos e seu aperfeiçoamento no limiar do século XXI. In: PINHEIRO, Paulo Sérgio; GUIMARÃES, Samuel Pinheiro (org.). Direitos humanos no século XXI. Brasília: IPRI - Instituto de Pesquisa de Relações Internacionais Fundação Alexandre de Gusmão, 2002, p. 273-302.

BRASIL. Ato Regimental n. 5, 2002. Advocacia-Geral da União. Disponível em: $<$ http://www.agu.gov.br/page/content/detail/id_conteudo/113488>. Acesso em: 20 out. 2015.

Constituição (1988). Constituição da República Federativa do Brasil. Brasília, DF: Senado Federal: Centro Gráfico, 1988.

CPI sistema carcerário. Congresso Nacional. Câmara dos Deputados. Comissão Parlamentar de Inquérito do Sistema Carcerário. Brasília: Câmara dos Deputados, Edições Câmara, 2009.

Decreto n. 8.162, de 18 de dezembro de 2013. Aprova a Estrutura Regimental e o Quadro Demonstrativo dos Cargos em Comissão e das Funções de Confiança da Secretaria de Direitos Humanos da Presidência da República e remaneja cargos em comissão. Disponível em: <http://www.planalto.gov.br/ccivil_03/_Ato20112014/2013/Decreto/D8162.htm>. Acesso em: 20 out. 2015.

Lei n. 7.210, de 11 de julho de 1984. Institui a Lei de Execução Penal. Disponível 
em: <http://www.planalto.gov.br/ccivil_03/leis/L7210compilado.htm>. Acesso em: 20 out. 2015.

Lei n. 9.807, de 13 de julho de 1999. Estabelece normas para a organização e a manutenção de programas especiais de proteção a vítimas e a testemunhas ameaçadas, institui o Programa Federal de Assistência a Vítimas e a Testemunhas Ameaçadas e dispõe sobre a proteção de acusados ou condenados que tenham voluntariamente prestado efetiva colaboração à investigação policial e ao processo criminal. Disponível em: <http://www.planalto.gov.br/ccivil_03/leis/L9807.htm>. Acesso em: 20 out. 2015.

Lei n. 11.343, de 23 de agosto de 2006. Institui o Sistema Nacional de Políticas Públicas sobre Drogas - Sisnad; prescreve medidas para prevenção do uso indevido, atenção e reinserção social de usuários e dependentes de drogas; estabelece normas para repressão à produção não autorizada e ao tráfico ilícito de drogas; define crimes e dá outras providências. Disponível em: <http://www.planalto.gov.br/ccivil_03/_ato20042006/2006/lei/111343.htm>. Acesso em: 20 out. 2015.

Lei n. 12.847, de 2 de agosto de 2013. Institui o Sistema Nacional de Prevenção e Combate à Tortura; cria o Comitê Nacional de Prevenção e Combate à Tortura e o Mecanismo Nacional de Prevenção e Combate à Tortura; e dá outras providências.. Disponível em: <http://www.planalto.gov.br/ccivil_03/_Ato20112014/2013/Lei/L12847.htm>. Acesso em: 20 out. 2015.

Levantamento Nacional de Informações Penintenciárias - Infopen. Ministério da Justiça., jun. 2014. Disponível em: <http://www.justica.gov.br/noticias/mj-divulgaranovo-relatorio-do-infopen-nesta-terca-feira/relatorio-depen-versao-web.pdf $>$. Acesso em: 20 out. 2015.

Levantamento Nacional de Informações Penintenciárias - Infopen Mulheres. Ministério da Justiça., jun. 2014. Disponível em: <http://www.justica.gov.br/noticias/estudotraca-perfil-da-populacao-penitenciaria-feminina-no-brasil/relatorio-infopen-mulheres.pdf $>$. Acesso em: 20 out. 2015.

Portaria n. 212, de 30 de abril de 2008. Ministério das Relações Exteriores. Disponível em: <http://www.itamaraty.gov.br/images/RISE.pdf>. Acesso em: 20 out. 2015.

Programa Nacional de Direitos Humanos (PNDH-3). Secretaria Especial dos Direitos Humanos da Presidência da República. Brasília: SEDH/PR, 2010.

CANÇADO TRINDADE, Antônio Augusto. Direito das organizações internacionais. 5. ed. revista, atualizada e ampliada. Belo Horizonte: Del Rey, 2012.

Tratado de Direito Internacional dos Direitos Humanos, v. 1, 1. ed. Porto Alegre: Sérgio Antonio Fabris Editor, 1997.

Tratado de Direito Internacional dos Direitos Humanos, v. 3, 1. ed. Porto Alegre: Sérgio Antonio Fabris Editor, 2003. 
CAPPELLETTI, Mauro; GARTH, Bryant. Acesso à justiça. Trad. Ellen Gracie Northfleet. Porto Alegre: Sergio Antonio Fabris Editor, 1988.

CARVAlHO, José Murilo de. Cidadania no Brasil: o longo caminho. 15. ed. Rio de Janeiro: Civilização Brasileira, 2012.

CARVALHO, Salo de; FREIRE, Christiane Russomano. O regime disciplinar diferenciado: notas críticas à reforma do sistema punitivo brasileito. In: CARVALHO, Salo de (coord.). Crítica à execução penal. Rio de Janeiro: Editora Lumen Juris, 2007, p. 269- 292.

CARVALHO, Salo de; WUNDERLICH, Alexandre. O suplício de Tântalo: a Lei 10.792/03 e a consolidação da política criminal do terror. In: CARVALHO, Salo de (org.). Leituras constitucionais do sistema penal contemporâneo. Rio de Janeiro: Editora Lumen Juris, 2004, p. 383-386.

CARVALHO, Sandra; BAKER, Eduardo. Experiências de litígio estratégico no Sistema Interamericano de Proteção dos Direitos Humanos. Sur - Revista Internacional de Direitos Humanos, São Paulo, v. 11, n. 20, p. 465-75, jun./dez. 2014.

CASTILHO, Ela Wiecko Volkmer de. O controle da legalidade na execução penal. Porto Alegre: Sergio Antonio Fabris Editor, 1988.

CAVALLARO, J. L.; BREWER, E. O papel da litigância para a justiça social no Sistema Interamericano. Sur - Revista Internacional de Direitos Humanos, São Paulo, v. 5, n. 8, p. 84-99, dez. 2010.

CID, José; LARRAURI, Elena. Sistema Penal \& Violência, Porto Alegre, v. 1, n. 1, p. 121, jul./dez. 2009.

COIMBRA, Elisa Mara. Sistema Interamericano de Direitos Humanos: desafios à implementação das decisões da Corte no Brasil. Sur - Revista Internacional de Direitos Humanos, São Paulo, v. 10, n. 19, p. 56-73, dez. 2013.

COMISSÃO INTERAMERICANA DE DIREITOS HUMANOS. Ampliação das medidas cautelares n. 199/11 - Pessoas privadas de liberdade na Prisão Professor Aníbal Bruno, 2012. Disponível em: <http://www.oas.org/pt/cidh/decisiones/cautelares.asp>. Acesso em: 20 out. 2015.

Consideraciones sobre la ratificación universal de la Convención Americana y otros tratados interamericanos en materia de derechos humanos, 2014. Disponível em: $<$ https://www.oas.org/es/cidh/informes/pdfs/Universalizacion-sistema-interamericano.pdf $>$. Acesso em: 20 out. 2015.

Documentos básicos de derechos humanos en el Sistema Interamericano. Disponível em: <http://www.oas.org/es/cidh/mandato/documentos_basicos.asp >. Acesso em: 20 out. 2015.

Informe sobre el impacto del mecanismo de solución amistosa, 2013. Disponível

em: $<$ http://www.oas.org/es/cidh/soluciones_amistosas/docs/Informe-Soluciones- 
Amistosas.pdf>. Acesso em: 20 out. 2015.

$\begin{array}{lccccr} & \text { Medidas cautelares } & \text { n. } & \text { 199/11 } & \text { - Pessoas privadas de libertade } & \text { na Prisão } \\ \text { Professor } & \text { Aníbal } & \text { Bruno, } & 2011 . & \text { Disponível } & \text { em } \\ <\text { http://www.oas.org/pt/cidh/decisiones/cautelares.asp }>\text {. Acesso em: } 20 \text { out. } 2015 . & \end{array}$

Princípios e boas práticas sobre a proteção das pessoas privadas de liberdade nas Américas, 2009. Disponível em: <https://cidh.oas.org/pdf\%20files/PRINCIPIOS \%20PORT.pdf $>$. Acesso em: 20 out. 2015.

COMPARATO, Fábio Konder. Afirmação histórica dos direitos humanos. 3. ed. São Paulo: Saraiva, 2004.

CONSElHO NACIONAL DO MINISTÉRIO PÚBLICO. A visão do Ministério Público brasileiro sobre o sistema prisional brasileiro. Brasília : CNMP, 2013.

CORTE INTERAMERICANA DE DIREITOS HUMANOS. Resolução de 22 de Maio de 2014. Medidas provisórias a respeito do Brasil. Complexo Penitenciário do Curado. Disponível em: <http://www.corteidh.or.cr/docs/medidas/curado_se_01_por.pdf >. Acesso em: 20 out. 2015.

. Resolução de 7 de Outubro de 2015. Medidas provisórias a respeito do Brasil. Complexo Penitenciário do Curado. Disponível em: $<$ http://www.corteidh.or.cr/docs/medidas/curado_se_02_por.pdf $>$. Acesso em: 20 out. 2015.

DALLARI, Dalmo de Abreu. Elementos de teoria geral do Estado. 12. ed. São Paulo: Saraiva, 1986.

DELLA PORTA, Donatella; TARROW, Sidney. Transnational protest and global activism. Lanham: Rowman \& Littlefield Publishing Group, 2005.

DINIZ, Debora. Carta de uma orientadora. O primeiro projeto de pesquisa. 2. ed. rev. Brasília: LetrasLivres, 2013.

. Esteriótipos de gênero nas cortes internacionais - um desafio à igualdade: entrevista com Rebecca Cook. Estudos Feministas, Florianópolis, v. 19, n. 2, p. 451-462, mai./ago. 2011.

FOUCAULT, Michel. Vigiar e punir: nascimento da prisão. Trad. Lígia Pondé Vassallo. Petrópolis: Vozes, 1977.

FONSECA, Lívia Gimenes Dias da. A luta pela liberdade em casa e na rua: a construção do Direito das mulheres a partir do projeto Promotoras Legais Populares do Distrito Federal. 2012. 171 f. Dissertação (Mestrado em direito) - Faculdade de Direito da UnB, Universidade de Brasília, Brasília/DF.

GALDINO, Danielle de Souza. Proteção pela metade: um estudo sobre as necessidades humanas no Programa Federal de Assistência a Vítimas e Testemunhas Ameaçadas. 2013. 229 f. Dissertação (Mestrado em política social) - Instituto de Ciências Humanas da 
UnB, Universidade de Brasília, Brasília/DF.

GARCÍA-MUÑOZ, Soledad. La progresiva generización de la protección internacional de los derechos humanos. Revista Electrónica de Estudios Internacionales, Asociación Española de Profesores de Derecho Internacional y Relaciones Internacionales, n. 2, p. 1-33, jun. 2001. Disponível em: <http://www.reei.org/index.php/revista/num2/notas/progresivagenerizacion-proteccion-internacional-derechos-humanos>. Acesso em: 20 out. 2015.

GONZÁLEZ, Felipe. As medidas de urgência no Sistema Interamericano de Direitos Humanos. Sur - Revista Internacional de Direitos Humanos, São Paulo, v. 7, n. 13, p. 5073, jun. 2010.

GORENSTEIN, Fabiana. Imunidade parlamentar: reflexões sobre o litígio no Sistema Interamericano de Proteção aos Direitos Humanos. In: LIMA JÚNIOR, Jayme Benvenuto (org.) Direitos Humanos Internacionais - avanços e desafios no início do século XXI. Recife: GAJOP, 2001, p. 142-160.

HABERMAS, Jürgen. Sobre a constituição da Europa: um ensaio. Trad. Denilson Luis Werle, Luiz Repa e Rúrion Melo. São Paulo: Editora Unesp, 2012.

HERRERA FLORES, Joaquín. Teoria crítica dos direitos humanos: os direitos humanos como produtos culturais. Rio de Janeiro: Editora Lumen Juris, 2009.

HOUAISS, Antônio. Dicionário Houaiss da Língua Portuguesa. Rio de Janeiro, Ed. Objetiva, 2001.

HUNT, Lynn. A invenção dos direitos humanos. Uma história. São Paulo: Companhia das Letras, 2009.

KECK, Margareth E.; SIKKINK, Kathryn. Activists beyond borders. Advocacy networks in international politics. Ithaca: Cornell University Press, 1998.

LYRA FILHO, Roberto. O que é Direito? 11. ed. São Paulo: Brasiliense, 1982.

MACDOWELL SANTOS, Cecília (org.). A mobilização transnacional do direito: Portugal e o Tribunal Europeu dos Direitos Humanos. Coimbra: Edições Almedina, 2012.

MACDOWELL SANTOS, Cecília. Ativismo jurídico transnacional e o Estado: reflexões sobre os casos apresentados contra o Brasil na Comissão Interamericana de Direitos Humanos. Sur - Revista Internacional de Direitos Humanos, São Paulo, v. 4, n. 7, p. 27 57, jun. 2007.

MAC-GREGOR, Eduardo Ferrer. Las siete principales líneas jurisprudenciales de la Corte Interamericana de Derechos Humanos aplicable a la justicia penal. Revista IIDH/Instituto Interamericano de Derechos Humanos, San José, Costa Rica, n. 59, p. 29-118, ene./jun. 2014. 
MORIN, Edgar. Ciência com consciência. 10. ed. Trad. Maria D. Alexandre e Maria Alice Sampaio Dória. Rio de Janeiro: Bertrand Brasil, 2007.

MÜLLER, Friedrich. Quem é o povo? A questão fundamental da democracia. 5 ed. Revista e atualizada. Trad. Peter Naumann. São Paulo: Revista dos Tribunais, 2010.

NEVES, Marcelo. Do diálogo entre as cortes supremas e a Corte Interamericana de Direitos Humanos ao transconstitucionalismo na América Latina. Revista de Informação Legislativa, Brasília, a. 51, n. 201, p. 193-214, jan./mar. 2014a.

(Não) solucionando problemas constitucionais: transconstitucionalismo além de colisões. Lua Nova, São Paulo, n. 93, p. 201-232, 2014 b.

ORGANIZAÇÃO DOS ESTADOS AMERICANOS. Carta da OEA, 1948. Disponível em $<$ http://www.oas.org/es/sla/ddi/tratados_multilaterales_interamericanos_A-

41_carta_OEA.asp>.Acesso em: 20 out. 2015.

. Convenção Americana sobre Direitos Humanos, 1969. Disponível em $<$ https://www.oas.org/dil/esp/tratados_B-

32_Convencion_Americana_sobre_Derechos_Humanos.htm>. Acesso em: 20 out. 2015.

Convenção Interamericana para Prevenir e Punir a Tortura, 1985. Disponível em: $<$ https://www.oas.org/pt/cidh/mandato/Basicos/tortura.pdf $>$. Acesso em: 20 out. 2015.

Declaração Americana de Direitos e Deveres do Homem, 1948. Disponível em $\overline{<\mathrm{http}: / / w w w . o a s . o r g / e s / c i d h / m a n d a t o / B a s i c o s / d e c l a r a c i o n . a s p>. ~ A c e s s o ~ e m: ~} 20$ out. 2015.

PASTORAL CARCERÁRIA et al. Arquivo Aníbal. Disponível em: $<$ http://arquivoanibal.weebly.com/>. Acesso em: 20 out. 2015.

PINHEIRO, Paulo Sérgio; MESQUITA NETO, Paulo de. Direitos humanos no Brasil: perspectivas no final do século. In: PINHEIRO, Paulo Sérgio (org.). Pesquisas: Cinquenta anos da Declaração Universal dos Direitos Humanos. Rio de Janeiro: Centro de Estudos Konrad Adenauer Stiftung, 1998, p. 53-70.

PIOVESAN, Flávia. Direitos humanos e justiça internacional. 2. ed. São Paulo: Saraiva, 2011a.

Direitos humanos e o direito constitucional internacional. 12. ed. revista e atualizada. São Paulo: Saraiva, 2011 b.

O caso Márcia Barbosa e a imunidade parlamentar. In: LIMA JÚNIOR, Jayme Benvenuto (org.) Direitos Humanos Internacionais - avanços e desafios no início do século XXI. Recife: GAJOP, 2001, p. 161-168.

Temas de direitos humanos. 7. ed. São Paulo: Saraiva, 2014.

PRONER, Carol. Os direitos humanos e seus paradoxos: análise do Sistema Americano de Proteção. Porto Alegre: Sergio Antonio Fabris Editor, 2002. 
PUREZA, José Manuel. Prefácio. In: MACDOWELL SANTOS, Cecília (org.). A mobilização transnacional do direito: Portugal e o Tribunal Europeu dos Direitos Humanos. Coimbra: Edições Almedina, 2012, p. 9-11.

QUIJANO, Aníbal; WALLERSTEIN, Immanuel. Americanity as a concept, or the Americas in the modern world-system. International Social Science Journal, v. 44, n. 4, p. 549-557, 1992.

RAMOS, André de Carvalho. Processo internacional de direitos humanos. 3. ed. São Paulo: Saraiva, 2013.

RAMOS, Leonardo César Souza. A sociedade civil em tempos de globalização: uma perspectiva neogramsciana. Rio de Janeiro: PUC-Rio, Instituto de Relações Internacionais, 2005.

ROSATO, Cássia Maria; CORREIA, Ludmila Cerqueira. Caso Damião Ximenes Lopes: mudanças e desafios após a primeira condenação do Brasil pela Corte Interamericana de Direitos Humanos. Sur - Revista Internacional de Direitos Humanos, São Paulo, v. 8, n. 15, p. 93-114, dez. 2011.

SÁNCHEZ RUBIO, David. Crítica a una cultura estática y anestesiada de derechos humanos. Por una recuperación de las dimensiones constituyentes de la lucha por los derechos. In: MULLER, Cristiano; AZEVEDO, Karla Fabrícia Moroso Santos de (org.). Os conflitos fundiários urbanos no Brasil: estratégias de luta contra os despejos e empoderamentos a partir da teoria crítica dos direitos humanos. Porto Alegre: CDES Direitos Humanos, 2014, p. 13-50.

Sobre el concepto de historización. Una crítica a la visión sobre las de-generaciones de derechos humanos. Praxis, n. 67, p. 9-22, jul./dic. 2011.

SANTOS, Boaventura de Sousa. Globalizations. Problematizing global knowledge Genealogies of the global/Globalizations. Theory, Culture and Society, n. 23, p. 393-399, 2006.

Poderá o direito ser emancipatório? Revista Crítica de Ciências Sociais, Coimbra, Portugal, n. 65, p. 03-76, mai. 2003.

. Para uma revolução democrática da justiça. 3. ed. São Paulo: Cortez, 2011.

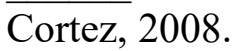

Pela mão de Alice. O social e o político na pós-modernidade. 12. ed. São Paulo:

SANTOS, Boaventura de Sousa; CHAUÍ, Marilena. Direitos humanos, democracia e desenvolvimento. São Paulo: Cortez, 2013.

SANTOS, Boaventura de Sousa; RODRÍGUEZ-GARAVITO, César A. Law, politics and the subaltern in counter-hegemonic globalization. In: SANTOS, Boaventura de Sousa; 
RODRÍGUEZ-GARAVITO, César A. (ed.). Law and globalization from below. Cambridge: University Press, 2005, p. 1-26.

SEGATO, Rita Laura. Antropologia e direitos humanos: alteridade e ética no movimento de expansão dos direitos universais. Maná, Rio de Janeiro, v. 12, n. 1, p. 207-236, 2006.

Ejes argumentales de la perspectiva de la Colonialidad del Poder. Revista Casa de las Americas, La Habana, Cuba, n. 272, p. 17-39, jul./sep. 2013.

. El color de la cárcel en América Latina: apuntes sobre la colonialidad de la justicia en un continente en desconstrucción. Nueva Sociedad, Buenos Aires, Argentina, n. 208, p. 142-161, mar/apr. 2007.

Território, soberania e crimes de segundo estado: a escritura nos corpos das mulheres de Ciudad Juarez. Estudos Feministas, Florianópolis, v. 13, n. 2, p. 265-285, mai./ago. 2005.

SIKKINK, Kathryn. A emergência, evolução e efetividade da rede de direitos humanos da América Latina. In: JELIN, Elizabeth; HERSHBERG, Eric (org.). Construindo a democracia: direitos humanos, cidadania e sociedade na América Latina. São Paulo: Editora da Universidade de São Paulo, 2006, p. 97-132.

SILVA, José Afonso da. Curso de Direito Constitucional Positivo. 24. ed. São Paulo: Malheiros, 2005.

SILVA, Antonio Henrique Ferreira da. Era inútil prender: uma história do Presídio Professor Aníbal Bruno. Revista Tempo Histórico, Recife, v. 5, n. 1, p. 1-21, 2013.

SONNENBERG, Stephan; CAVALLARO, James L. Name, shame, and then build consensus? Bringing conflict resolution skills to human rights. Washington University Journal of Law \& Policy, Washington, United States of America, v. 39, n. 257, p. 257-307, 2012.

SOUSA JÚNIOR, José Geraldo de. Por uma concepção alargada do Acesso à Justiça. Revista Jurídica, Brasília, v. 10, n. 90, ed. esp., p. 1-14, abr./mai. 2008.

TARROW, Sidney. O poder em movimento: movimentos sociais e confronto político. Trad. Ana Maria Sallum. Petrópolis, RJ: Vozes, 2009.

VIEIRA, Oscar Vilhena (coord.). Implementação das recomendações e decisões do sistema interamericano de direitos humanos no Brasil: institucionalização e política. 1. ed. São Paulo: Direito GV, 2013.

VON BÜLOW, Marisa. A batalha do livre comércio: a construção de redes transnacionais da sociedade civil nas Américas. 1. ed. São Paulo: Editora Unesp, 2014.

WACQUANT, Loïc. The Penalisation of Poverty and the Rise of Neo-liberalism. European Journal on Criminal Policy and Research, Milano, Italia, n. 9, p. 401-412, 2001. 
Toward a dictatorship over the poor? Notes on the penalization of poverty in Brazil. Punishment and Society, London, Thousand Oaks and New Delhi, v. 5, n. 2, p. 197-205, 2015.

WEIS, Carlos. Direitos humanos contemporâneos. 2. ed. São Paulo: Malheiros Editores, 2010 .

ZAFFARONI, Eugenio Raúl. Manual de direito penal brasileiro, v. 1: parte geral/Eugenio Raúl Zaffaroni e José Henrique Pierangeli. 8. ed. rev. e atua. São Paulo: Revista dos Tribunais, 2009.

ZAFFARONI, Eugenio Raúl; LEMGRUBER, Julita. A esquerda tem medo, não tem política de segurança pública. Eugenio Raúl Zaffaroni entrevistado por Julita Lemgruber. Revista Brasileira de Segurança Pública, v. 1, n. 1, p. 130-139, 2007.

ZILLI, Marcos; MONTECONRADO, Fabíola Girão; MOURA, Maria Thereza Rocha de Assis. O Brasil e a execução das decisões proferidas no contexto do Sistema Interamericano de Direitos Humanos. In: ELSNER, Gisela (ed.). Sistema Interamericano de Protección de los Derechos Humanos y Derecho Penal Internacional. Bogotá, Colombia: Fundación Konrad Adenauer, 2013, p. 83-134. 


\section{ANEXO}

\section{QUESTIONÁRIO PARA ENTREVISTA}

\begin{tabular}{|l|l|}
\hline Informações & 1) Quando foi fundada? Por quem? \\
básicas para & a) Qual é a sua missão institucional? \\
contextualização & 3) Existe estatuto/regulamento? (se existir, é possível envio em anexo?) \\
da organização & 4) Quem compõem a equipe responsável pelo caso? \\
& 5) Onde é a sede? \\
& 6) Que tipo de atuação promove em relação a direitos humanos? E em relação ao \\
& sistema prisional? \\
& 7) Possui assento em alguma instituição no âmbito local, regional, nacional e \\
& internacional que desenvolva suas atividades relativamente ao tema da segurança \\
& pública, do sistema prisional e/ou do combate à tortura? \\
& 8) Que tipo de participação tem no acompanhamento do caso Presídio Professor \\
& Aníbal Bruno perante o Sistema Interamericano de Direitos Humanos? \\
& 9) A organização tem outras demandas no Sistema Interamericano de Direitos \\
& Humanos? Outras demandas internacionais? Quais?
\end{tabular}

Formação da rede de 10) Como se formou a rede de organizações da sociedade civil?

$\begin{array}{ll}\text { organizações } & \text { 11) A rede se formou para ingressar com a demanda no SIDH ou para outra }\end{array}$ finalidade?

Funcionamento da 12) Como funciona a rede?

rede de organizações 13) Existe uma divisão de tarefas?

14) Que estratégias foram incialmente pensadas?

15) Como essas estratégias foram mudando ao longo do tempo?

16) Como acontece a circulação de informação dentro da rede?

Formulação da 17) Por que o Presídio Professor Aníbal Bruno foi escolhido como denúncia $\quad$ paradigmático entre as unidades em Pernambuco? Que critérios foram utilizados?

18) Existe um interesse da organização em todo o sistema prisional de Pernambuco? E no sistema prisional brasileiro?

Internacionalização da 19) Como (por quem, quando, a partir de que critérios) foi tomada a demanda decisão de que se ingressaria com uma demanda internacional? 


\begin{tabular}{|l|l|}
\hline 20) O que o Sistema Interamericano proporciona para as organizações da \\
sociedade civil? \\
21) Dentro do Brasil existe algum espaço que seja semelhante ao da \\
Comissão e da Corte Interamericana de Direitos Humanos? \\
22) Houve o esgotamento dos recursos internos? Como avaliam esse \\
obstáculo ao ingresso de demandas no SIDH? \\
23) Por que houve a decisão de ingresso de medidas cautelares?
\end{tabular} \mid $\begin{aligned} & \text { 24) Como (por quem, quando, a partir de que critérios) foi tomada a } \\
& \text { decisão de que se ingressaria com uma demanda no SIDH e não na ONU } \\
& \text { por exemplo? } \\
& \text { 25) Pensaram em algum outro espaço institucional? } \\
& \text { 26) A rede tem acionado meios de proteção das Nações Unidas? Algum } \\
& \text { outro mecanismo? }\end{aligned}$

